Universidad de Lima

Facultad de Derecho

Carrera de Derecho

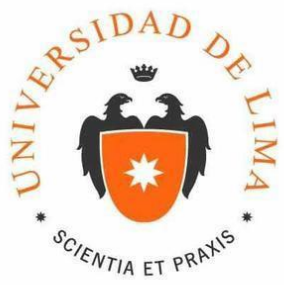

\title{
LA NECESIDAD DE UNA RESPUESTA NORMATIVA EN CONTRA DE LAS PRÁCTICAS DE ELUSIÓN FRENTE AL DERECHO ANTIDUMPING: MODIFICACIÓN DEL DECRETO SUPREMO N ${ }^{\circ}$ 006-2003-PCM
}

Tesis para optar el Título Profesional de Abogado

\section{Giuliana Georgina Paredes Soto}

Código 20090837

\author{
Asesor \\ Julio Baltazar Durand Carrión
}

Lima - Perú

Noviembre de 2016 


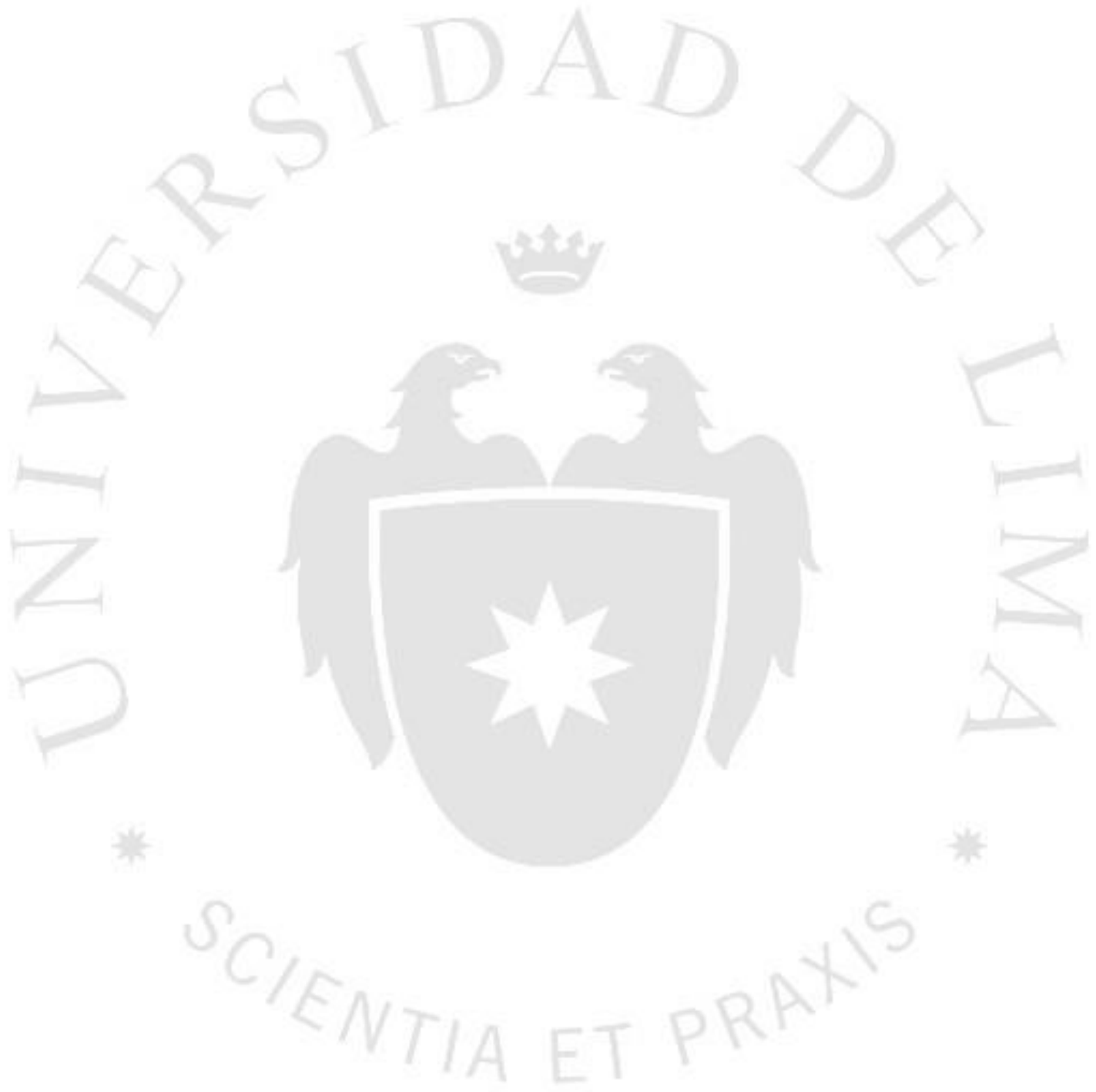


LA NECESIDAD DE UNA RESPUESTA

NORMATIVA EN CONTRA DE LAS

PRÁCTICAS DE ELUSIÓN FRENTE AL DERECHO ANTIDUMPING: MODIFICACIÓN

\author{
DEL DECRETO \\ SUPREMO ${ }^{\circ}$ 006- \\ 2003-PCM
}




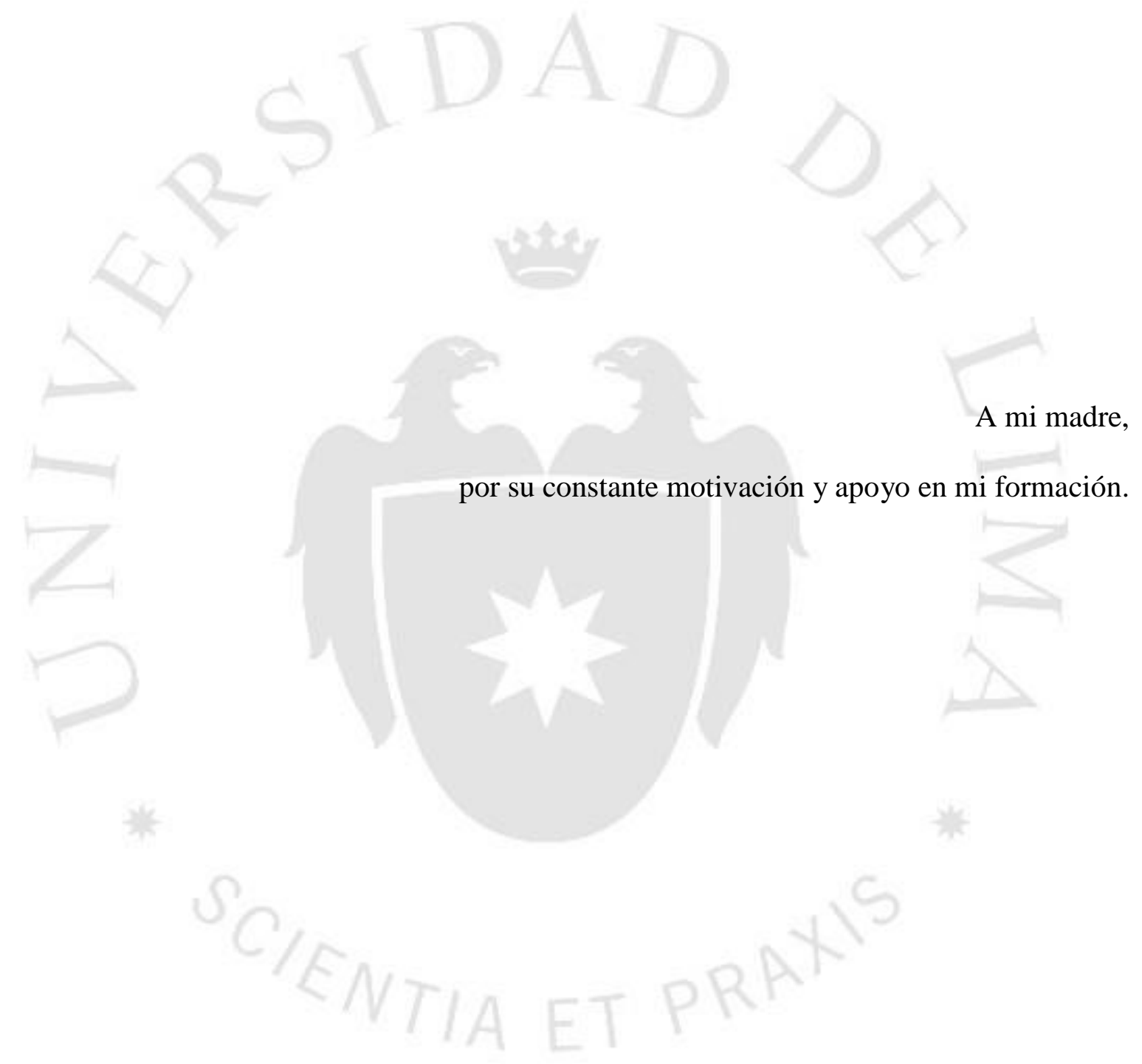




\section{ÍNDICE}

INTRODUCCIÓN .1

\section{Capítulo I APERTURA COMERCIAL}

1.1. ANTECEDENTES Y EFECTOS DE LA APERTURA COMERCIAL INTERNACIONAL 6

\section{Capítulo II PRECIOS DUMPING}

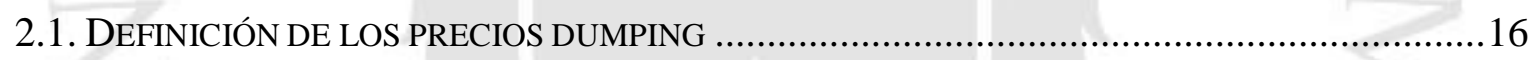

2.1.1. DERECHO DE COMPETENCIA Y NORMAS DUMPING ............................................ 18

2.1.2. PRECIOS DUMPING COMO PRECIOS PREDATORIOS .............................................21

2.1.3. PRECIOS DUMPING COMO DISCRIMINACIÓN INTERNACIONAL DE PRECIOS ................22

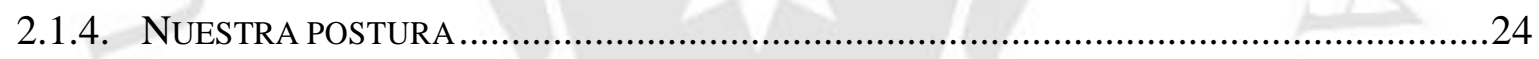

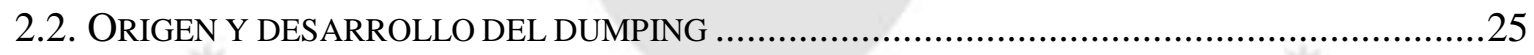

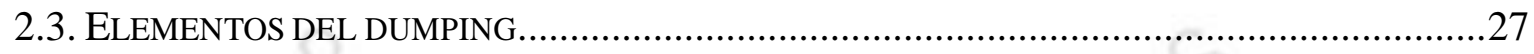

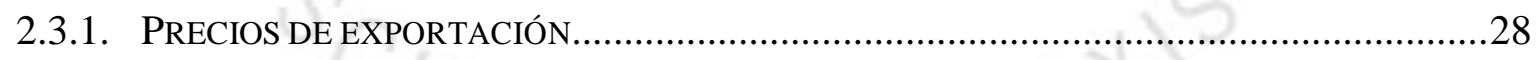

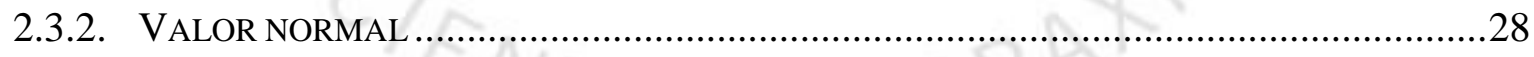

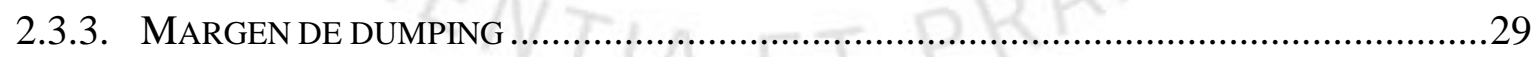

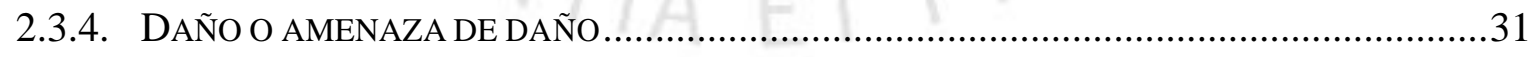

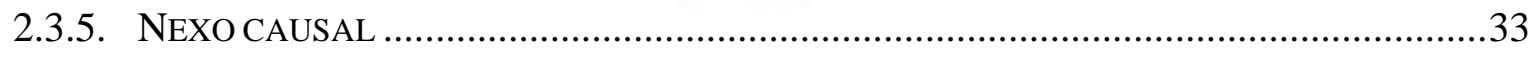

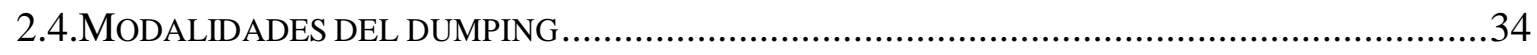

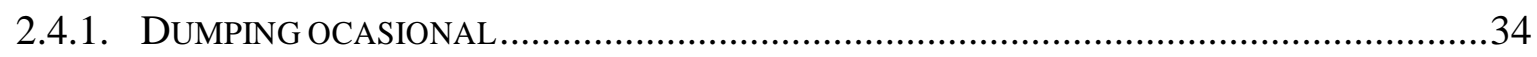

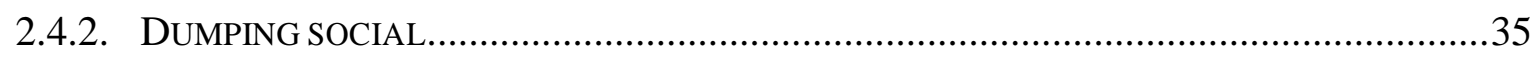

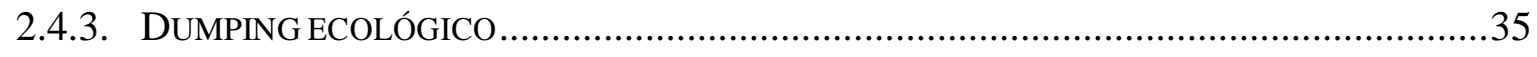

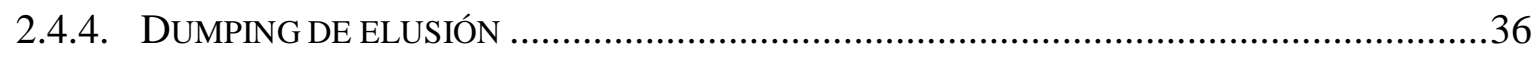




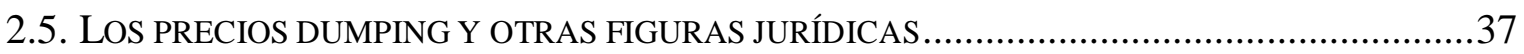

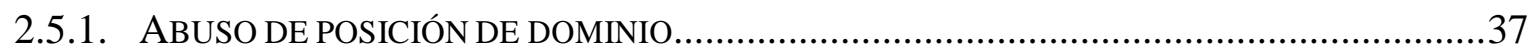

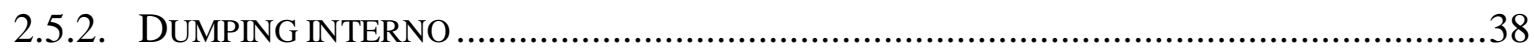

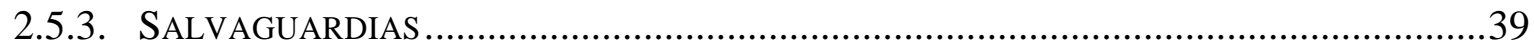

\section{CAPÍtUlo III DERECHOS}

ANTIDUMPING

3.1. NATURALEZA JURÍDICA DEL DERECHO ANTIDUMPING ..............................................41

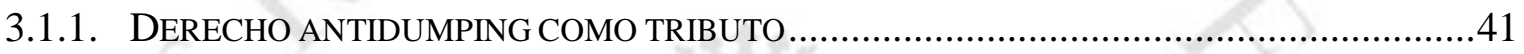

3.1.2. DERECHO ANTIDUMPING COMO MULTA ………………........................................4

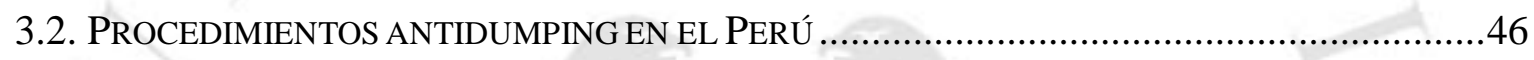

3.2.1. SUJETOS QUE PARTICIPAN EN EL PROCEDIMIENTO ANTIDUMPING .............................48

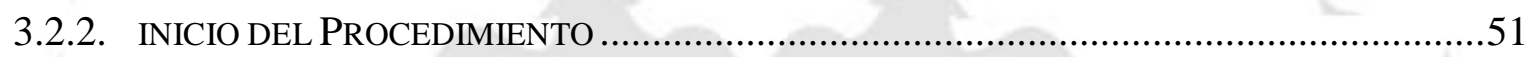

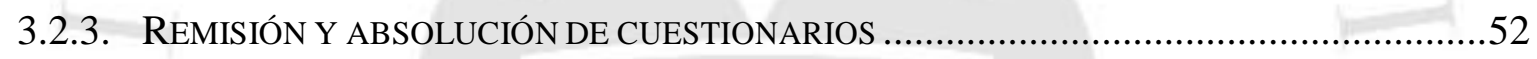

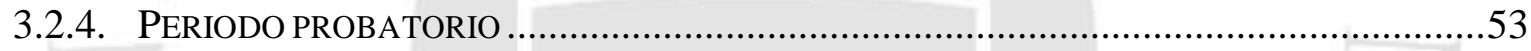

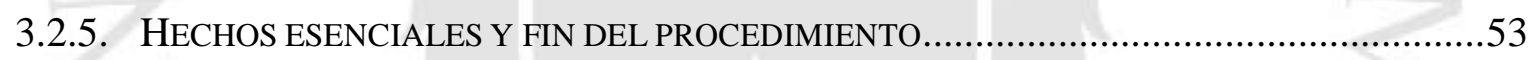

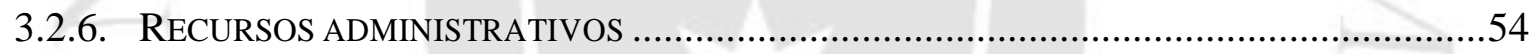

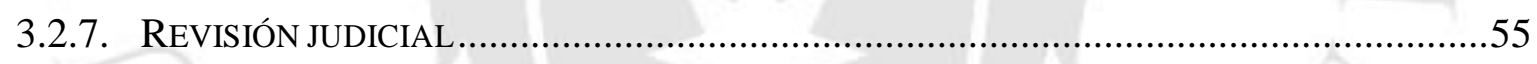

CAPítulo iv

PRÁCTICAS ELUSIVAS FRENTE AL DERECHO ANTIDUMPING

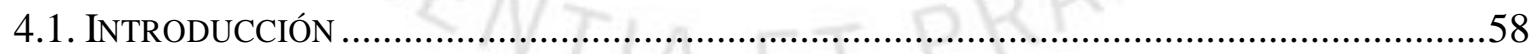

4.2.DEFINICIÓN DE PRÁCTICAS DE ELUSIÓN Y SUS MODALIDADES ………………………......66

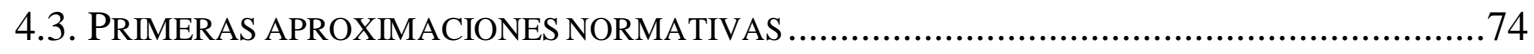




\section{CAPítulo V LEGISLACIÓN \\ COMPARADA}

5.1. IMPORTANCIA DE SU ANÁLISIS

5.2. NORMAS ANTIELUSIÓN EN ESTADOS UNIDOS 78

5.2.1. PRODUCTOS COMPLETADOS O ENSAMBLADOS EN LOS ESTADOS UNIDOS ..................79

5.2.2. MERCANCÍA COMPLETADA O ENSAMBLADA EN UN TERCER PAÍS ...............................79

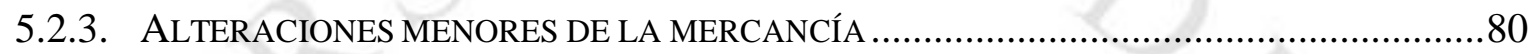

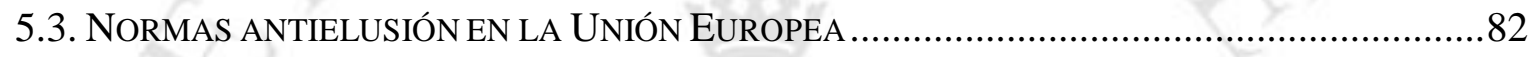

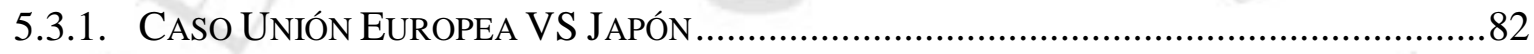

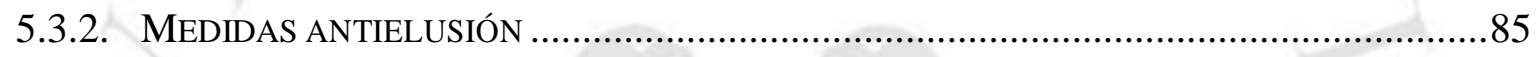

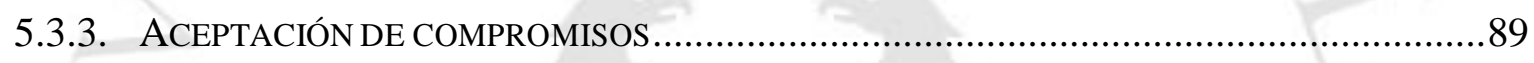

5.3.4. ARTí́CULO 13:10 DE LA REGULACIÓN DE LA UNIÓN EUROPEA..................................90

5.3.5. PUBLICACIONES DE CRITERIOS Y REGLAS ADMINISTRATIVAS ...................................90

5.3.6. REGLAMENTOS VIGENTES EN LA UNIÓN EUROPEA ……………………………........92

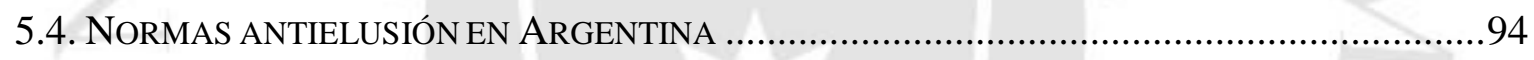

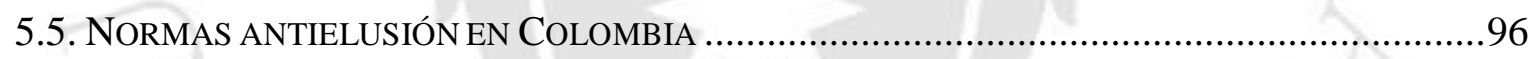

5.6. NORMAS ANTIELUSIÓN EN EL MARCO DE LA COMUNIDAD ANDINA DE NACIONES ..........99

\section{CAPítulo VI \\ PRÁCTICAS DE ELUSIÓN Y MECANISMO DE ANTIELUSIÓN}

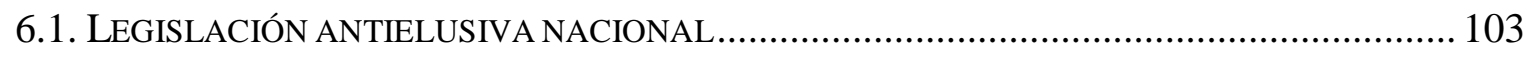

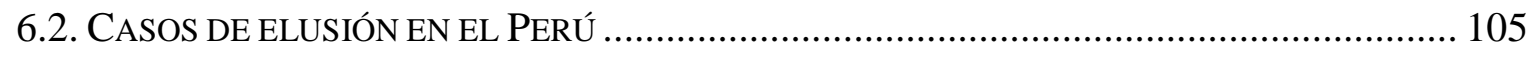

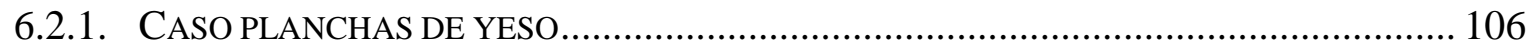

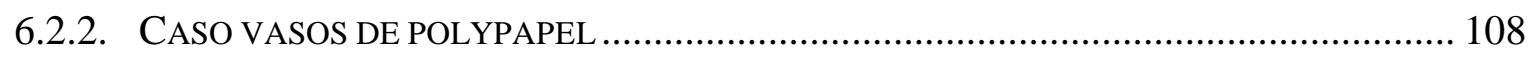

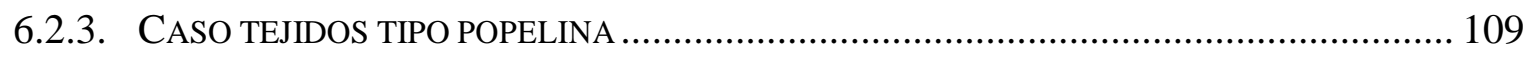


6.3. FUNDAMENTOS PARA LA MODIFICACIÓN DEL REGLAMENTO ANTIDUMPING PERUANO 112 6.3.1. CONFORMIDAD DE LAS MEDIDAS ANTIELUSIVAS RESPECTO A LA NORMATIVA

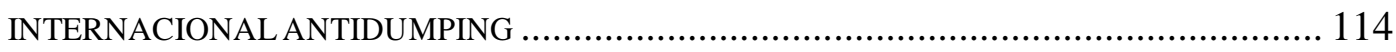

6.3.2. INCREMENTO DE PRÁCTICAS ELUSIVAS EN UN CONTEXTO DE VACÍO LEGAL............. 116

6.3.3. MEDIDAS ANTIELUSIVAS, LA COMPETENCIA Y LAS VENTAJAS COMPARATIVAS...... 116

6.3.4. LA TEORÍA DEL DILEMA DEL PRISIONERO............................................................ 119

6.4. Proyecto de modificación del Reglamento Antidumping Peruano ................ 120

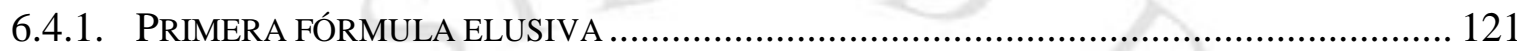

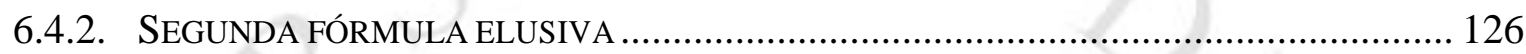

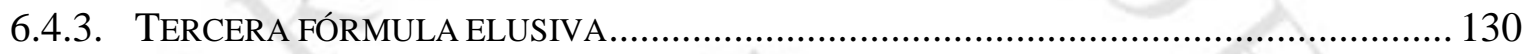

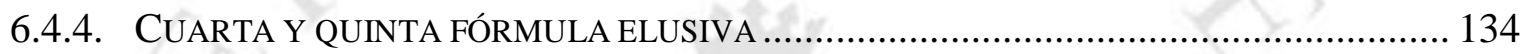

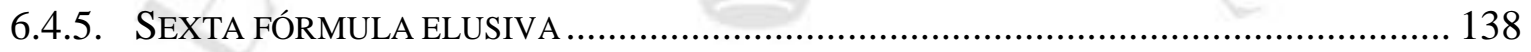

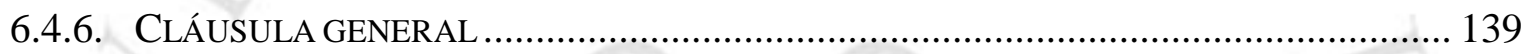

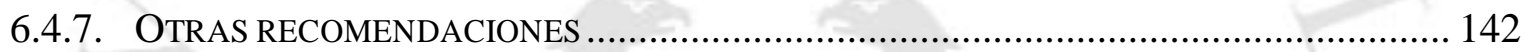

6.5. UN ALCANCE ECONÓMICO SOBRE LA MODIFICACIÓN NORMATIVA .................................. 143

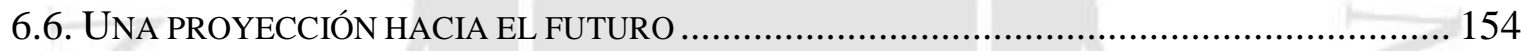

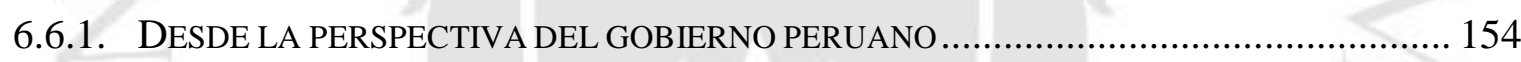

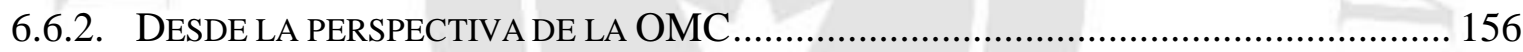

6.6.3. DESDE LA PERSPECTIVA DE LOS ACUERDO COMERCIALES...................................... 158

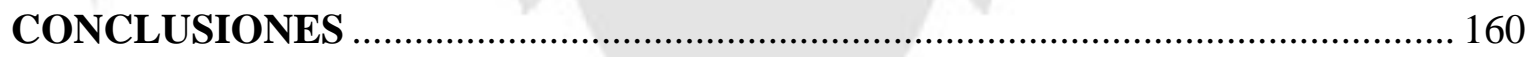

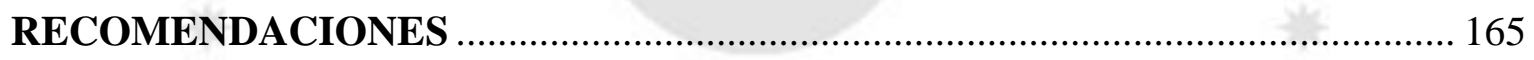

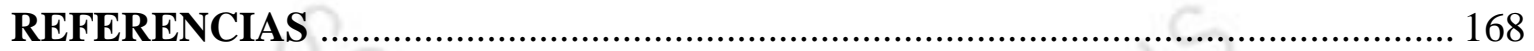

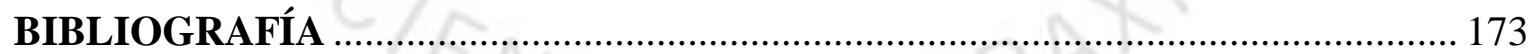

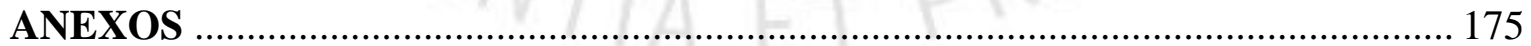




\section{ÍNDICE DE TABLAS}

TABLA 1.1: (RONDAS DE NEGOCIACIÓN DE LA OMC DESDE 1947 HASTA LA ACTUALIDAD). 13

TABLA 4.1: (MEDIDAS ANTIDUMPING DEROGADAS, EN PREPARACIÓN Y VIGENTES APLICADAS EN ESTADOS UNIDOS Y LA UNIÓN EUROPEA DESDE 1994 HASTA EL 2015). .59

TABLA 4.2. (MEDIDAS ANTIDUMPING DEROGADAS, EN PREPARACIÓN Y VIGENTES APLICADAS EN ESTADOS UNIDOS Y LA UNIÓN EUROPEA DESDE 1994 HASTA EL 2015 .59

TABLA 5.1. (RESUMEN SOBRE LOS DATOS EN LOS PROCEDIMIENTOS ANTIDUMPING DE LEGISLACIONES COMPARADAS)

102

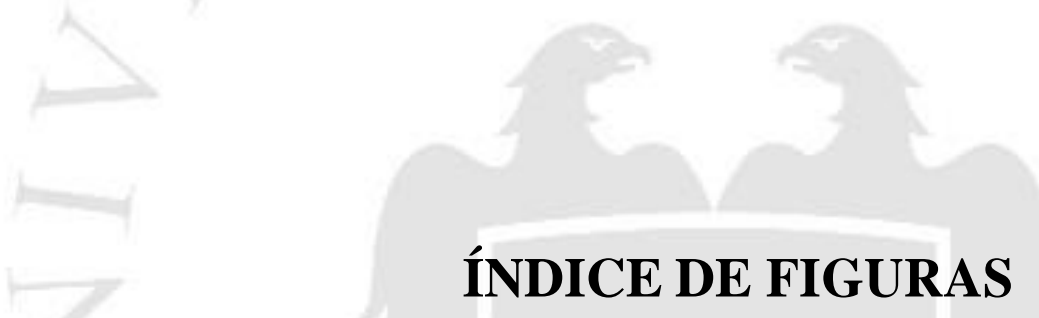

Figura 6.1: (BALANZA de PAgOS DE PERÚ DESDE EL 2002 AL 2015)

FIGURA 6.2: (PRINCIPALES DESTINOS: EXPORTACIONES TEXTILES EN MILLONES DE DÓLARES)... 


\section{INTRODUCCIÓN}

La investigación que se desarrollará a continuación se concentrará en el análisis de una conducta que está atentado en contra del comercio internacional y, más específicamente, del sistema antidumping; nos referimos a la ejecución creciente de prácticas de elusión de los derechos antidumping. Para poder abordar este tema tendremos que estudiar cuestiones previas, tales como la incidencia de los precios con margen dumping en el país importador y las medidas de defensa comercial que son aplicadas para equilibrar los precios dumping de exportación.

La globalización, la tecnología y la apertura comercial generaron la interconexión de los países y de sus agentes comerciales. Sin embargo, en un primer momento, cada país impulsó sus propios intereses, por lo que, se generaron prácticas hostiles que posicionaran a unos países respecto a otros. Para enfrentar esta situación, se determinó la creación del Fondo Monetario Internacional y el Banco Mundial, instituciones que ejercen un control económico-financiero. En el ámbito comercial, se reconoció la ejecución de prácticas desleales, tales como la exportación de productos a precios dumping. Para poder enfrentar de forma uniforme, los daños generados por aquellas conductas, se han emitido acuerdos multilaterales que han determinado la aplicación de derechos antidumping.

El Derecho Antidumping tiene su origen en el Acuerdo General sobre Aranceles y Comercio GATT de 1947, entendida correlativa y conjuntamente con el Acuerdo General sobre Aranceles y Comercio GATT de 1994 y complementada con el Acuerdo Relativo a la Aplicación del Artículo VI del Acuerdo General sobre Aranceles Aduaneros y Comercio de 1994 (en adelante Acuerdo Antidumping), documento que establece los lineamientos requeridos para los procedimientos antidumping en la legislación interna de los países miembros. Toda esta respuesta legislativa internacional fue una respuesta a la coyuntura comercial generada por la discriminación internacional de precios provocada tras la liberalización comercial. 
En el marco nacional peruano, la normativa aplicable a conductas dumping consiste en el Decreto Supremo $N^{\circ}$ 133-91-EF, modificado por el Decreto Supremo $\mathrm{N}^{\circ}$ 051-92-EF que establecen normas para evitar y corregir las distorsiones de la competencia en el mercado generadas por el dumping y es aplicable a los países no miembros de la OMC. Por otro lado, el Decreto Supremo N 006-2003-PCM, modificado por el Decreto Supremo N 004-2009-PCM (en adelante Reglamento Antidumping) ha sido emitido para reglamentar las normas previstas en el Acuerdo relativo a la aplicación del artículo VI del Acuerdo General sobre Aranceles Aduaneros y Comercio 1994 y es aplicado a los países miembros de la OMC.

Tanto el Acuerdo Antidumping como el Reglamento Antidumping establecen los criterios que deberán ser tomados en cuenta por la autoridad competente para dar curso a una solicitud sobre prácticas dumping; alguno de estos hacen referencia a:

a. La existencia de un margen de dumping, que resulta de la diferencia del valor normal y del precio de exportación, que supere el minimis establecido en un $2 \%$ por el Reglamento Antidumping.

b. La acusación de daño, amenaza de daño o retraso sensible a la creación de una rama de producción nacional como consecuencia del incremento de las importaciones materia de investigación.

c. La determinación de un nexo causal entre el daño o amenaza de daño y las importaciones dumping.

Una vez configurado estos supuestos de hecho, la autoridad administrativa del país importador tiene la prerrogativa de equilibrar dicha situación mediante la ejecución del Derecho Antidumping. La Organización Mundial de Comercio creó el mecanismo antidumping con un doble propósito, en primer lugar, se busca eliminar toda distorsión que se genere en razón de las transacciones comerciales entre los países miembros y, en segundo lugar, se busca proteger a la industria nacional del país de destino que pudiera 
sufrir cierto daño o amenaza de daño provocado por un practica dumping de discriminación internacional de precios.

Lo cierto es que una vez que se implementó y reglamentó respecto al derecho antidumping en la legislación interna de los países miembros, los estudios y análisis económicos de la OMC registraron el incremento en la aplicación de dichos mecanismos. Bajo este contexto, los exportadores de los países a quienes se les aplicaba continuamente los derechos antidumping empezaron a incurrir en prácticas de elusión con el fin de evitar el pago de los derechos aplicados por la autoridad competente del país importador.

Esta problemática del incremento de las conductas de elusión fue planteada en diversas negociaciones en las que participaron todos los países miembros de la OMC y fue encabezado por el Grupo Informal sobre Elusión (Comisión encargada para dirigir la causa), sin embargo, debido a las dicotómicas posiciones dentro de las negociaciones, no se llegó a ningún acuerdo.

A pesar de que no se logró formular una normativa internacional que regulara el tema, la OMC reconoció los problemas que implicaban las prácticas elusivas en el comercio internacional; ello impulsó a varios países, tales como los Estados Unidos, la Unión Europea, Argentina, México, entre otros, a emitir normas internas que reprimieran los actos elusivos. La respuesta de estos países responde, pues a la incapacidad de la OMC de poder definir una posición respecto a la elusión que comprometa de forma uniforme a los países y que sirva como base para la posterior reglamentación interna. Sin embargo, la inacción de la OMC no impide el ejercicio soberano que tiene cada país para normar prácticas que se considere se aparta de la legalidad, por tanto, el hecho de plantear dispositivos antielusión resultaría completamente legítimo.

En nuestro país, la Comisión de Dumping, Subsidios y Eliminación de Barreras no Arancelarias del INDECOPI ha planteado el tema en solo un artículo del Reglamento Antidumping. Este dispositivo solo hace referencia a uno de los supuestos de elusión que se aplicará solo en la importación de partes piezas o componentes. Lo cierto es que este 
artículo es muy limitado, primero, porque no se establece un procedimiento administrativo especial para extender la aplicación de derechos antidumping en caso de elusión, sino que hace un simple reenvío a las disposiciones establecidas en los artículos 21 al 57 del mismo Reglamento; por otro lado, se debe entender que la génesis del derecho proviene del aspecto social, es decir, el derecho se moldea de acuerdo a las circunstancias y el actuar humano. Ahora, en el aspecto comercial, la elusión se ha diversificado en diversas conductas, tales como la importación del producto final a un tercer país; la alteración insignificante, pero suficiente para modificar la partida arancelaria del producto al que se le aplicó originalmente derechos antidumping; la importación ya no del producto final, sino de sus partes o componentes en un tercer país o al país de destino para su ensamblaje, entre otros. Lo cierto es que cada vez se van configurando más supuestos de elusión por parte de los exportadores, por tanto, mal se haría en repeler las prácticas elusivas de forma tan limitada, pues finalmente la única disposición que lo regula, no refleja la complejidad de la problemática.

Una clara consecuencia de la limitada disposición antielusión es que se reduce la capacidad de acción y sanción de la autoridad administrativa. Cabe reconocer que existe casuística que evidenciaría un posible accionar elusivo, sin embargo, en las oportunidades en las que la Comisión extendió los derechos antidumping por elusión, el Poder Judicial resolvió declarar nula la Resolución Administrativa Final y exigió levantar la medida, pues se consideró que la sanción violaba el principio de legalidad, en la medida de que no existe una norma primaria antielusión que desencadene la aplicación de la norma secundaria (normas que sancionan el incumplimiento de las normas primarias) que extiende la aplicación de derechos antidumping.

Por tanto, la problemática en este caso radica en el evidente vacío legal que limita el correcto accionar de la Comisión de Dumping, Subsidios y Eliminación de Barreras no Arancelarias respecto a su función de repeler las distorsiones en el comercio internacional como lo son las prácticas elusivas de derechos antidumping. 
Con arreglo a ello, el pasado 12 de diciembre de 2011 se realizó una presentación en la que se plantea la modificación del artículo 58 del Decreto Supremo N 006-2003PCM donde se incluyen disposiciones que comprenden otros supuestos de elusión, una cláusula general y preceptos procedimentales. La presente investigación va a plantear comentarios, sugerencias y lineamientos generales respecto a la propuesta de modificación normativa.

Como se puede notar, el tema central, materia de la presente investigación, trasciende el ámbito del Derecho Internacional del Comercio para expandirse hacia otras materias como: Derecho Aduanero, Derecho Internacional Público y Economía; por lo que, se concluye que la naturaleza de esta tesis es compuesta.

Esta tesis va a comprender y analizar las prácticas elusivas realizadas desde los años 80' hasta la fecha dentro de un marco internacional. Y busca, específicamente, examinar la respuesta legislativa de Estados Unidos, la Unión Europea y otros países frente a estas conductas.

El objetivo principal de la presente investigación consiste en establecer la necesidad de reglamentar en contra de las prácticas de elusión, además de brindar los lineamientos generales para la modificación del Decreto Supremo N ${ }^{\circ}$ 006-2003-PCM, respetando los acuerdos internacionales suscritos por nuestro país, tales como el GATT de 1947 y 1994 y el Acuerdo Antidumping. Una normativa antielusión permitirá asimismo delimitar el grado de intervención del INDECOPI.

Para la realización del objetivo planteado, se va a emplear los siguientes Métodos Generales: método analítico, método inductivo y método histórico. Mientras que los métodos específicos se proyectan en el método exegético y funcional. Asimismo, con el fin de recabar información preponderante para el desarrollo y elaboración del presente trabajo, se va a hacer uso de la Técnica de Entrevista a funcionarios de INDECOPI, Sociedad de Comercio Exterior del Perú (COMEX) y la Sociedad Nacional de Industrias. 


\section{Capítulo I}

\section{APERTURA COMERCIAL}

\subsection{ANTECEDENTES Y EFECTOS DE LA APERTURA COMERCIAL INTERNACIONAL}

Cuando se habla de comercio internacional, se hace referencia al "intercambio de bienes y servicios entre Estados o países soberanos o libres" (Sierralta Ríos, 2007, pág. 40). El comercio entre naciones es estudiado por el Derecho Internacional del Comercio $^{1}$ que establece regulaciones que se configuran de acuerdo a cada régimen jurídico interno, además de ello, el comercio internacional se encuentra subyugado a la normativa emitida por instituciones que forman parte del sistema internacional de comercio y finanzas.

Pero ¿cómo se explica el nacimiento, desarrollo y despegue del comercio internacional? Con el fin de responder a esta interrogante se deberá recurrir al estudio de hechos históricos que tomaron lugar en el antiguo siglo XVIII y que delimitaron el escenario comercial en nuestros tiempos. Con arreglo a ello, mencionaremos brevemente la postura de algunas teorías que se han desarrollado con el fin de explicar este fenómeno de auge comercial.

1 Cabe anotar que "La denominación de esta nueva rama del Derecho como Derecho Internacional del Comercio es más lógica y comprensiva ya que se trata de un derecho sustantivo. A ello se une que corresponde y guarda relación con la tradición jurídica internacional que sólo diferencia estas ramas especializadas por el adjetivo" (Sierralta Ríos A. , 2001, pág. 184) 
Por un lado, se tiene a la Teoría de las Ventajas Comparativas que resume su fundamento en la venta por parte de una nación de su producción y la compra en el mercado extranjero de los productos que no se encuentran en el mercado local. Sin embargo, esta teoría no podría explicar cabalmente el nacimiento y desarrollo del comercio internacional, pues debe tenerse en cuenta que las transacciones comerciales se realizan bajo el marco de un mercado imperfecto respecto a la oferta y demanda, asimismo, el comercio internacional se rige por elementos muchas veces variables y volátiles.

Por otro lado, la Teoría de las Economías de Escala en la Producción explica que la industria nacional va a producir mercancías que puedan satisfacer la demanda del mercado local y el excedente de dicha producción se exporta al mercado extranjero. Consecuentemente, una producción a gran escala va a permitir la reducción del costo unitario de las mercancías, por tanto, la utilidad generada va a ser mayor. Con arreglo a esta teoría, la génesis del comercio internacional se debe a la producción sobrante en determinada industria, la cual es exportada hacia un tercer país. Este supuesto sólo podrá ser concebido en un mercado imperfecto.

Mas la teoría que aborda este fenómeno desde una perspectiva más profunda e histórica es la Teoría Centro Periférica que no solo explica que la Revolución Industrial y el nuevo orden económico - financiero concebido en razón de la Segunda Guerra Mundial son las bases históricas que explican la evolución del comercio internacional, sino que además concibe a dichos acontecimientos como la causa de la desigualdad en la economía mundial. A continuación, se pasará a explicar el fundamento histórico en el que se basa esta teoría.

Si retrocedemos en la historia, el punto de quiebre que determinó la transformación económica y tecnológica fue la Revolución Industrial, suceso que engendró a mediados del siglo XVIII una nueva etapa: la era comercial. Ahora bien, según la teoría bajo análisis, ese hito generó la creación dicotómica de dos grupos: el del centro y la periferia. Por un lado, los países del centro desarrollan una producción basada en la tecnología y valor agregado lo que perfila una estructura industrial diversificada. Mientras que los países de la periferia se caracterizan por enfocar su 
economía y política comercial hacia la producción y exportación netamente de productos primarios, prescindiendo de toda manufactura o valor agregado, por tanto, esta estructura productiva se caracteriza por ser más bien especializada y heterogénea. La falta de tecnología y organización en el proceso productivo va moldeando así una economía rezagada.

En base a lo antes indicado, la teoría en cuestión concluye que la Revolución Industrial fue el evento que determinó la subsecuente asimetría en las relaciones comerciales internacionales entre los países latinoamericanos y los países desarrollados.

El momento cumbre de esta evolución se determinó justamente en la segunda mitad del siglo XX, momento en el cuál muchos países adoptaron políticas económicas de apertura comercial en el que el intervencionismo estatal resulta ser cada vez nimio. Los años siguientes fueron escenario de importantes hechos que impulsaron la consolidación de un mundo comercial globalizado. Se fortaleció la fuerza comercial de los países europeos ante la creación de la Unión Europea, Estados Unidos se delimitaba como potencia económica y el despegue comercial de los países asiáticos fue, del mismo modo, trascendental.

Como se puede entender, la coyuntura de intercambio se proyectó en crecimiento durante muchos años hasta que estalló la Primera Guerra Mundial, evento que generó un impacto negativo al conglomerado de países y sus intenciones comerciales, pues todas las industrias se encontraban arruinadas.

Frente a este panorama desolador y con el propósito de proteger sus industrias, muchos países empezaron a recurrir a medidas proteccionistas respecto a exportaciones extranjeras. Uno de esos países fue Estados Unidos, nación que además de haber vivido los estragos de la Primera Guerra, atravesó en 1930 por una crisis económica. Al respecto, procuraron el incremento de la tasa aduanera a través del Arancel Smoot Hawley.

El arancel Smoot-Hawley, que fue promulgado en vísperas del colapso económico a principios de 1930, estará asociado por siempre con un brote de proteccionismo en todo el mundo, el colapso del comercio mundial y el inicio 
de la Gran Depresión. (...) El arancel fue desacreditado como consecuencia del desastre económico que apareció por su causa. El Smoot-Hawley ha sido acusado de envenenar las relaciones comerciales internacionales mediante la activación de una ola de aumentos en las tarifas extranjeras que ponen al comercio mundial en una espiral descendente. El Smoot-Hawley incluso ha sido acusado de convertir la recesión en la Gran Depresión.

(Douglas A., 2004, pág. 326)

Como se observa las políticas de gobierno adoptadas por los países se vinculaban íntimamente con la coyuntura comercial que se vivía en ese entonces, por tanto, podría decirse que el alza de los aranceles constituía la herramienta y el medio para alcanzar los objetivos proteccionistas propuestos por dicho gobierno.

Posteriormente, se produjo una seguidilla de acontecimientos que significaron la transición a una etapa marcada por la tecnología, globalización e integración comercial. Ello se materializó, por un lado, en el ámbito económico, mediante el Acuerdo de Bretton Woods y, por el otro lado, en el ámbito comercial, mediante la Carta de Habana y su intención de crear la Organización Internacional de Comercio (en adelante OIC).

La crisis económica global que sobrevino debido a la Gran Depresión en Estados Unidos, la Segunda Guerra Mundial y las prácticas comerciales hostiles impulsó y demarcó la creación de un nuevo orden económico, financiero y comercial. En primera instancia, el acuerdo de Bretton Woods planteó reconstruir la economía mundial a través de la creación de entidades internacionales.

La Conferencia de Bretton Woods, oficialmente conocida como la Conferencia Monetaria y Financiera de las Naciones Unidas, fue una reunión de delegados de 44 naciones que se congregó del 1 al 22 de julio de 1944 en Bretton Woods, New Hampshire, para ponerse de acuerdo sobre una serie de nuevas reglas para el sistema monetario internacional luego de la Segunda Guerra Mundial. Los dos hechos más destacados de la conferencia fueron la creación del Fondo Monetario Internacional (FMI) y el Banco Internacional de Reconstrucción y Fomento (BIRF). (...) Los funcionarios se adhirieron a la corriente de 
Wilsonian que reconoce que el libre comercio no sólo promueve la prosperidad internacional, sino también la paz internacional (...). Las políticas adoptadas por los gobiernos para combatir la Gran Depresión por los altos aranceles, las devaluaciones competitivas de la moneda, los bloques discriminatorios de comerciales que habían contribuido a la creación de un entorno internacional inestable sin mejorar la situación económica. Esta experiencia llevó a los líderes internacionales a la conclusión de que la cooperación económica era la única manera de lograr la paz y la prosperidad, en el interior y en el extranjero. (U.S. Department of State, 2009)

Como se observa, el esfuerzo de los países consistía en la creación de diversas instituciones supranacionales que se encargaran del control económico, financiero y comercial de los países participantes. Con tal propósito se concibió al Fondo Monetario Internacional y al Banco Internacional de Reconstrucción y Fomento; mientas que la creación de la Organización Internacional de Comercio fue una intención fallida:

- Fondo Monetario Internacional (FMI): Organización creada el 27 de diciembre de 1945, cuya regulación es aplicada a 188 países miembros. La Carta Constitutiva del FMI plantea sus principales objetivos:

En el artículo I del Acuerdo del Fondo Monetario Internacional afirma que uno de los principales objetivos del Fondo es facilitar la expansión y el crecimiento equilibrado del comercio internacional y contribuir así a la promoción y el mantenimiento de los altos niveles de empleo y los ingresos reales y al desarrollo de los recursos productivos de todos los países miembros como objetivo primordial de la política económica.

(CVCE, 2012)

Para lograr este propósito, el FMI debe dirigir sus esfuerzos en corregir las distorsiones proyectadas en las balanzas de $\operatorname{pagos}^{2}$ de los países miembros y

2 La balanza de pagos es el registro en dólares de todos los ingresos y egresos de una nación. Antes de la creación del FMI y ante la falta de control supranacional, los países, en un marco de guerra comercial, recurrían al aumento indiscriminado de los aranceles aplicados a productos extranjeros, ello provocaba el desequilibrio de la balanza de pagos del país importador. Naturalmente, este acto de 
supervisar la estabilidad de las tasas de cambio ${ }^{3}$. Mientras que la modalidad de supervisión se establece de la siguiente manera:

Para mantener la estabilidad y prevenir la crisis en el sistema monetario internacional, el FMI pasa revista a las políticas económicas aplicadas por los países, así como a la situación económica y financiera nacional, regional y mundial a través de un sistema formal de supervisión. El FMI proporciona asesoramiento a los 188 países miembros y recomienda políticas que promuevan la estabilidad económica, reduzcan la vulnerabilidad a crisis económicas y financieras y mejoren los niveles de vida.

(Fondo Monetario Internacional, 2015)

- Banco Internacional de Reconstrucción y Fomento (BIRF): Conocido también como el Banco Mundial. El objetivo que impulsó su génesis consistía en la reconstrucción de los países afectados por la Segunda Guerra Mundial, enfocándose especialmente en la ayuda a las naciones europeas. Con la misma intención se firmó en París el 18 de abril de 1951 el Tratado Constitutivo de la Comunidad Europea del Carbón y del Acero ${ }^{4}$. Tras una década, dicha asociación reactivó su economía, reconstruyendo una unión industrializada.

Por tanto, la misión planteada por el Banco Mundial respecto a los países europeos se encontraba realizada, de este modo, la organización planteó continuar trabajando por el desarrollo de los Estados pobres, "facilitar el flujo de recursos entre las naciones y proporcionar capital destinado al crecimiento de los países en vías de desarrollo. (...) El Banco Mundial no sólo es un organismo

hostilidad era repetido por el país afectado, aplicándose aranceles más altos y generando un efecto dominó y demás perjudicial para el comercio internacional.

3 Otra modalidad de guerra comercial consistía en la devaluación de la moneda local y el subsecuente fortalecimiento del dólar, hecho que beneficiaba a las exportaciones, pues éstas se abarataban en el mercado externo.

$4 \quad$ El artículo 2 del citado documento dispone la misión que impulsa el accionar de los países suscriptores: "La Comunidad Europea del Carbón y del Acero tendrá por misión contribuir, en armonía con la economía general de los Estados miembros y mediante el establecimiento de un mercado común en las condiciones fijadas, a la expansión económica, al desarrollo del empleo y a la elevación del nivel de vida en los Estados miembros" (Boletín Oficial del Estado, 1986) 
de financiación sino también de asistencia económica” (Sierralta Ríos A. , 2007, pág. 66).

- Organización Internacional de Comercio: Por otro lado, en el ámbito comercial, la intención era la creación de la OIC mediante la Carta de la Habana que tenía como propósito favorecer la expansión de la producción, intercambio y consumo de mercaderías ${ }^{5}$ a través de la suscripción de acuerdos multilaterales que permitieran la liberalización del comercio.

Para ello, las Naciones Unidas encomendó la elaboración de la Carta de la OIC a un Comité Preparatorio que finalmente emitió la Carta de la Habana, sin embargo, ésta no fue aprobada debido a que no se alcanzó consenso entre los países participantes.

Mientras ello ocurría, los países miembros negociaron determinadas concesiones arancelarias que fueron proyectadas en el GATT de 1947 (General Agreement on Tariffs and Trade por sus siglas en inglés); se trataba pues de un compromiso que, por no haberse constituido como organización, carecía de personería jurídica.

De esta manera surgió el GATT, que era un punto intermedio y con menores ambiciones que la Carta de la Habana y que, además, tenía una menor

5 En el artículo I de la Carta de la Habana se detallan sus propósitos y objetivos de la siguiente manera: "(Las partes) se comprometen, individual y colectivamente, a promover medidas de carácter nacional e internacional destinadas a alcanzar los siguientes objetivos:

1. Asegurar un volumen considerable y cada vez mayor de ingreso real y demanda efectiva; aumentar la producción, el consumo y el intercambio de bienes y contribuir así al equilibrio y a la expansión de la economía mundial.

2. Fomentar y ayudar el desarrollo industrial y el económico en general, especialmente en aquellos países cuyo desarrollo industrial está aún en sus comienzos; y estimular la corriente internacional de capitales destinados a inversiones productivas.

3. Ampliar para todos los países, en condiciones de igualdad, el acceso a los mercados, a los productos y a los medios de producción necesarios para su prosperidad y desarrollo económicos.

4. Promover, sobre una bases de reciprocidad y de ventajas mutuas, la reducción de los aranceles aduaneros y demás barreras comerciales, así como la eliminación del tratamiento discriminatorio en el comercio internacional;

5. Capacitar a los países, dándoles mayores oportunidades para su comercio y desarrollo económico, para que se abstengan de adoptar medidas susceptibles de dislocar el comercio mundial, reducir el empleo productivo o retardar el progreso económico. (...)

EN CONSECUENCIA, establecen por la presenta la ORGANIZACIÓN INTERNACIONAL DE COMERCIO por medio de la cual cooperarán, como Miembros de ella, para lograr el propósito y los objetivos enunciados en el presente Artículo" 
representación pues lo suscribieron solo veintitrés Estados, el 30 de octubre de 1947, y sus concesiones entraron en vigor el 30 de junio de 1948.

(Sierralta Ríos A., 2014, p. 101)

En razón del GATT, los países suscriptores realizaron negociaciones periódicas en las que se debatían temas comerciales mediante rondas comerciales multilaterales. En la página web de la Organización Mundial de Comercio (1998) se establece la cronología del GATT/OMC que puede ser resumido de la siguiente manera:

Tabla 1.1

Rondas de negociación de la OMC desde 1947 hasta la actualidad

\begin{tabular}{|c|c|c|}
\hline Ronda & Periodo & Acuerdos \\
\hline Ginebra & 1947 & $\begin{array}{l}\text { Se negoció la reducción de aranceles aplicado entre las } \\
\text { partes contratantes. }\end{array}$ \\
\hline Annecy & 1949 & $\begin{array}{l}\text { Las partes contratantes intercambiaron unas } 5000 \\
\text { concesiones arancelarias. Asimismo otros diez países se } \\
\text { adhirieron al Acuerdo. }\end{array}$ \\
\hline Torquay & $1950-1951$ & $\begin{array}{l}\text { Las partes contratantes intercambiaron una } 8700 \\
\text { concesiones arancelarias. Cuatro países más se adhirieron } \\
\text { al Acuerdo General. Se concretó la no creación de la OIC. }\end{array}$ \\
\hline Ginebra & 1956 & $\begin{array}{l}\text { Se lograron reducciones arancelarias por valor de } 2500 \\
\text { millones de dólares y se inauguró el curso de política } \\
\text { comercial del GATT para funcionarios de los países en } \\
\text { desarrollo. }\end{array}$ \\
\hline Dillon & $1960-1962$ & $\begin{array}{l}\text { Se establecieron concesiones a la Comunidad Económica } \\
\text { Europea sobre la base de su Arancel Exterior Común y se } \\
\text { desarrolló una nueva serie general de negociaciones } \\
\text { arancelarias. }\end{array}$ \\
\hline Kennedy & $1964-1967$ & $\begin{array}{l}\text { Negociaciones lineales o grupales en vez de realizarlas } \\
\text { producto por producto. Se logró reducciones del } 50 \% \text { en } \\
\text { los niveles arancelarios y se negoció la emisión de un } \\
\text { Código Antidumping. }\end{array}$ \\
\hline Tokio & $1973-1979$ & Acuerdos sobre cuestiones arancelarias y no arancelarias. \\
\hline Uruguay & $1986-1994$ & $\begin{array}{l}\text { Se continuó con las reducciones arancelarias, se firmaron } \\
\text { acuerdos en materias tales como el comercio de servicios, } \\
\text { los derechos de propiedad intelectual, las medidas } \\
\text { sanitarias fitosanitarias, finalmente se estableció un } \\
\text { sistema permanente encarnado por la Organización } \\
\text { Mundial de Comercio reforzado para la resolución de } \\
\text { diferencias comerciales. }\end{array}$ \\
\hline Doha & $2001-$ & $\begin{array}{l}\text { Las negociaciones, que aún están en curso, buscan } \\
\text { delimitar los textos de los acuerdos en la agricultura y el } \\
\text { acceso a los mercados para los productos no agrícolas, } \\
\text { fortalecer las normas que regulan el comercio de servicios, } \\
\text { impulsar el comercio y agilizar los procedimientos } \\
\text { aduaneros, entre otros. }\end{array}$ \\
\hline
\end{tabular}

Fuente: Organización Mundial de Comercio

Elaboración: por mí

En: https://www.wto.org/spanish/news_s/pres98_s/pr088_s.htm 
Ha sido la Ronda de Uruguay la que trajo consigo importantes cambio en materia del comercio multilateral. Entre ellas, se puede hacer mención a la creación de la Organización Mundial de Comercio (OMC) y la emisión del GATT de 1994.

El 15 de abril de 1994, en Marruecos, se suscribe la Declaración de Marrakech, cuyo numeral sexto deja constancia de la firma de los acuerdos conseguidos en razón de la Ronda de Uruguay que tiene particular incidencia para la creación de la OMC. "Los Ministros declaran que al firmar el Acta final en que se incorporan los resultados de la Ronda Uruguay de Negociaciones Comerciales Multilaterales y al adoptar las Decisiones Ministeriales conexas inician la transición del GATT a la OMC.

(Organización Mundial de Comercio, 1994)

Si bien el GATT no se constituía con personalidad jurídica, ésta era vista por sus Miembros como una organización, pues cumplía el rol previsto, desde un inicio, para la OIC:

Hasta entonces, cuando se mencionaba al GATT, podía hacerse referencia a dos realidades distintas: 1) el GATT como "sistema normativo", es decir, al conjunto de normas que constituyen el Acuerdo General sobre Aranceles Aduaneros y el Comercio; 2) el GATT como "organismo internacional", es decir aquel que -a pesar del fracaso de su constitución formal- se fue conformando empíricamente con una personalidad precaria.

(Basaldúa, 2007, pág. 19)

Finalmente, tras la aprobación del "Acuerdo por el que se establece la OMC"6 se va a sistematizar todos los acuerdos suscritos bajo el control de una sola institución.

$6 \quad$ El Acuerdo por el que se establece la Organización Mundial de Comercio cuenta con 16 artículos. En el Artículo I se hace referencia al establecimiento de la Organización; el Artículo II delimita el ámbito de la OMC y señala que ésta "constituirá el marco institucional común para el desarrollo de las relaciones comerciales entre sus Miembros en los asuntos relacionados con los acuerdos e instrumentos jurídicos conexos"; por su parte, el Artículo III establece las funciones que van a regir la labor dentro de la OMC mediante la enunciación de cinco numerales; el Artículo IV hace referencia a la estructura de la OMC, estableciendo una Conferencia Ministerial que determina la creación de un Comité de Comercio y Desarrollo, un Comité de Restricciones por Balanza de Pagos y un Comité de Asuntos Presupuestarios, Financieros y Administrativos; un Consejo General; un Consejo del Comercio de Mercancías; un Consejo del Comercio de Servicios y un Consejo de los Aspectos de los Derechos de Propiedad Intelectual 
La OMC es la llamada a administrar las relaciones comerciales de todos los países miembros que deciden someter su accionar, en un marco del comercio internacional, a los principios, objetivos, lineamientos y normativa que persigue un marco de libre comercio.

Otro de los importantes cambios de la Ronda de Uruguay fue la emisión del GATT de 1994 contenido en el Anexo 1A del Acuerdo de la OMC ${ }^{7}$. El GATT de 1994 incorpora y tiene como foco de análisis al GATT de 1947, por tanto, para efectos de la presente investigación, ambos acuerdos serán entendidos de forma conjunta, usándose el término GATT para referirse indistintamente a uno u otro.

En los siguientes capítulos y por ser el núcleo de investigación de este trabajo, se hará especial referencia al Artículo VI del GATT sobre Derechos Antidumping que será analizado conjuntamente con el Acuerdo Relativo a la aplicación del Artículo VI del Acuerdo General sobre Aranceles Aduaneros y Comercio (En adelante Acuerdo Antidumping).

relacionado con el Comercio. Mientras que el Artículo VII establece una Secretaría de la OMC que será dirigida por un Director General. Respecto a la condición jurídica de la OMC, el artículo VIII establece que ésta "tendrá personalidad jurídica, y cada uno de sus Miembros le conferirá la capacidad jurídica necesaria para el ejercicio de sus funciones. (Organización Mundial de Comercio, 1994)

7 "El GATT de 1994 también incluye seis Entendimientos relativos a artículos del GATT de 1947, aranceles y Protocolos de Adhesión, y decisiones adoptadas al amparo del GATT entre 1948 y 1994 como parte de lo que a menudo se denomina el acervo del GATT" (Organización Mundial de Comercio, (s.f.)) 


\section{Capítulo II}

\section{PRECIOS DUMPING}

\subsection{DEFINICIÓN DE LOS PRECIOS DUMPING}

Se ha elaborado diversas definiciones en torno al dumping; así, por ejemplo, en el Diccionario Aduanero se señala que:

Dumping es la situación en la que el precio de exportación de determinada mercadería hacía otro territorio aduanero fuera menor a aquel con el que se comercializa la misma mercancía dentro del territorio aduanero de origen o de expedición. Con lo indicado se demuestra que, al expedirse a menor precio, puede existir una combinación entre quienes la comercialicen, y aun el poder público, a fin de poder hacer transacciones con ella en otro territorio aduanero.

(Tosi, 2011, pág. 82)

Por otro lado, en el libro Normas antidumping y antitrust en los Procesos de Integración, (Sotomayor Vértiz, 2003) define al dumping como:

Una terminología usada para referirse a una práctica del comercio internacional que consiste en vender productos en un mercado exterior a precios bajos. Los 
productos provienen de un mercado exportador y amenazan causar daño a la industria nacional del país importador. Esta práctica no solo representa un potencial peligro sino que en muchos casos la amenaza se torna en un daño concreto que afecta a los industriales nacionales. (pág. 22)

El mismo autor rechaza definir al dumping como un acto desleal de competencia, "ya que sus efectos no son nacionales, como sucede en el caso de los actos de competencia desleal. En realidad se trata de una práctica desleal de comercio internacional" (Sotomayor Vértiz, 2003, pág. 22)

Por su parte, Sierralta Ríos (2014), con arreglo a las prácticas comerciales con precios dumping, precisa que:

La palabra dumping deriva del verbo anglosajón to dump que significa vaciar de golpe, descargar en forma abrupta. De donde podemos entender que el término describe la acción de descargar de manera significativa y violenta los precios de bienes o mercaderías; es decir, bajar los precios significativamente con el objeto de desplazar, eliminar o impedir el desarrollo de la competencia en el mercado de destino. (pág. 196)

Finalmente, la definición dada por Carlos Carrillo (1996) vincula al dumping con la práctica de discriminación de precios: "Dumping se encuentra asociado a las prácticas comerciales consistentes en una discriminación de precios, que realiza un productor extranjero, entre el mercado interno y el mercado de exportación” ( pág. 126).

En base a las definiciones reseñadas se puede ver que el dumping es asociado indistintamente al uso de precios predatorios, a la práctica de discriminación de precios y a una restricción a la libre competencia. Se señala también que su empleo va a permitir la aplicación, por parte de las autoridades del país importador, de medidas que protejan a la industria nacional, a sus consumidores así como a la inversión extranjera. 
La maraña de definiciones puede generar que se mezclen erróneamente conceptos pertenecientes al Derecho de Competencia con normas antidumping o se vincule a los precios dumping con instituciones legales distintas. A continuación se analizará los diferentes criterios desarrollados en torno al dumping para, posteriormente, sugerir nuestra definición.

\subsubsection{DERECHO DE COMPETENCIA Y NORMAS DUMPING:}

Nuestro país persigue una economía social de mercado $^{8}$ a través de una política de competencia que garantiza la libertad de empresa. El rol del Estado ${ }^{9}$ se proyecta a controlar y regular toda actividad que pueda atentar contra la leal competencia, pues busca promover la competitividad entre los agentes económicos.

El Derecho de Competencia en el Perú, también conocido en otras legislaciones como Derecho Antitrust o Antimonopolio, comprende tres disciplinas interdependientes: la Libre Competencia, regulada por el Decreto Legislativo $N^{\circ} 1034$ Ley de Represión de Conductas Anticompetitivas; la Competencia Desleal, regulada por el Decreto Legislativo N 1044 Ley de Represión de la Competencia Desleal y la Protección al Consumidor, regulado por el Código de Protección y Defensa del Consumidor. Para efectos de esta investigación se hará referencia a las dos primeras disciplinas:

Por un lado, la libre competencia protege la participación de competidores en el mercado bajo el uso de mecanismos lícitos como, por ejemplo, emplear una mayor publicidad, ofrecer un mejor servicio post venta, garantizar una mejor calidad, entre otros.

$8 \quad$ Artículo 58 de la Constitución Política Peruana de 1993.- Economía Social de Mercado: la iniciativa privada es libre. Se ejerce en una economía social de mercado. Bajo este régimen, el Estado orienta el desarrollo del país, y actúa principalmente en las áreas de promoción de empleo, salud, educación, seguridad, servicios públicos e infraestructura.

$9 \quad$ Artículo 59 de la Constitución Política Peruana de 1993.- Rol Económico del Estado: El Estado estimula la creación de riqueza y garantiza la libertad de trabajo y la libertad de empresa, comercio e industria. El ejercicio de estas libertades no debe ser lesivo a la moral, ni a la salud, ni a la seguridad pública. El Estado brinda oportunidades de superación a los sectores que sufren cualquier desigualdad; en tal sentido, promueve las pequeñas empresas en todas sus modalidades (el subrayado es mío). 
El hecho de ejercer de forma licita el derecho, del que goza todo agente económico, a competir, puede generar un daño concurrencial frente a los otros competidores, pero ello es una consecuencia lógica de la libertad empresarial.

El problema radica cuando los actores económicos recurren a prácticas anticompetitivas que alteran el bienestar de la sociedad y, más específicamente, el de los consumidores. Es ahí donde entra a tallar los mecanismos de defensa de la competencia a través del INDECOPI ${ }^{10}$, entidad llamada a controlar toda imperfección del mercado, evitando los efectos nocivos que generan las prácticas irregulares.

Los mecanismos de defensa de la libre competencia se enfocan principalmente en el control de conductas como las de abuso de posición de dominio y prácticas colusorias; el control de estructuras, pues se busca evitar la concentración del poder económico a través de fusiones y adquisiciones; y la regulación económica respecto a monopolios, pues se busca simular condiciones de competencia.

Por otro lado, según el artículo 1 el Decreto Legislativo $\mathrm{N}^{\circ} 1044$ es la ley que tiene por objetivo reprimir todo acto o conducta de competencia desleal que tenga por efecto, real o potencial, afectar o impedir el adecuado funcionamiento del proceso competitivo. La autoridad administrativa analizará objetivamente toda conducta que resulte opuesta a la buena fe empresarial, bastará que se genere el riesgo para sancionar el acto desleal, no se exige la efectiva configuración de los efectos nocivos ${ }^{11}$.

10 Artículo 13 de la Ley de Represión de Conductas Anticompetitivas.- Las autoridades de competencia:

13.1. En primera instancia administrativa la autoridad de competencia es la Comisión, entendiendo por ésta a la Comisión de Defensa de la Libre Competencia del INDECOPI.

13.2. En segunda instancia administrativa la autoridad de competencia es el Tribunal, entendiendo por éste al Tribunal de Defensa de la Competencia y de la Protección de la Propiedad Intelectual del INDECOPI.

$11 \quad$ Artículo 7 de la Ley de Represión de la Competencia Desleal.- Condición de ilicitud:

7.1. La determinación de la existencia de un acto de competencia desleal no requiere acreditar conciencia o voluntad sobre su realización.

7.2. Tampoco será necesario acreditar que dicho acto genere un daño efectivo en perjuicio de otro concurrente, los consumidores o el orden público económico, bastando constatar que la generación de dicho daño sea potencial. 
El artículo sexto del mismo cuerpo legal contiene la cláusula general que hace referencia a la prohibición de una conducta tipificada en forma general como acto desleal, independientemente de la forma o medio que se emplee para su realización. Los artículos subsiguientes identifican un conjunto de conductas que forman parte de las modalidades de competencia desleal: actos de engaño, violación de normas, violación de secretos, actos de denigración, aprovechamiento del esfuerzo ajeno y sabotaje empresarial.

El Derecho de Competencia tiene un corte distinto al establecido por las normas antidumping. La normativa que forma parte integrante del Derecho de Competencia peruano fiscaliza el accionar de los agentes económicos dentro del territorio nacional; analiza la práctica de abuso de posición de dominio reflejado en sus aspectos generales tales como el mercado relevante, el porcentaje de participación, la concentración y la existencia de barreras de acceso; garantiza la protección a los agentes económicos competidores, a los consumidores y a todo el régimen económico constitucional; regula la actividad económica respecto a bienes y servicios. Mientras que las normas dumping proyectan sus disposiciones a nivel internacional, fundamentan su existencia principalmente en la protección de la industria nacional, son aplicados respecto a transacciones internacionales que recaen solamente en bienes y admiten como excepción las reglas del minimis ${ }^{12}$.

Es importante entender la diferencia existente entre cada normativa, pues así se justifica y entiende que cada cual tiene su propio marco de aplicación, así como sus respectivos lineamientos y propósitos. Muchos autores planteaban sustituir las normas antidumping por las del Derecho de Competencia, sin embargo, en un contexto de comercio exterior, es evidente la eficacia de las primeras frente a las segundas.

En base a lo señalado líneas arriba, se entiende que es erróneo definir a los precios dumping como actos desleal de competencia, pues ello significaría proyectarlo al Derecho de Competencia con efectos nacionales, mas se sabe que la práctica dumping requiere la existencia de un escenario de mercado internacional en el que participen dos actores

$12 \quad$ Véase la página 29. 
comerciales, así tenemos por un lado al país exportador del producto con un precio dumping y por otro, al país importador, por tanto, resulta más conveniente definir al precio dumping como un acto desleal de comercio internacional.

\subsubsection{PRECIOS DUMPING COMO PRECIOS PREDATORIOS:}

Consiste en una estrategia comercial empleada por un exportador respecto al precio de los productos enviados al país de destino; en este caso, el precio de exportación resulta ser menor al precio del mismo producto establecido en el mercado de origen. El precio predatorio hace referencia a una doble intención que motiva el accionar del exportador; por un lado, lo que se pretende es abarcar la demanda de los consumidores del país importador en base a la proyección de precios bajos; por otro lado, el exportador busca hacerse del mercado y una vez posicionado dentro de éste procurará eliminar toda competencia para situarse como un agente monopólico.

Un mercado de monopolio ${ }^{13}$ es el escenario perfecto para que el exportador reforme y aumente sus precios de venta, ello con el fin de recuperar todas las pérdidas que generó operar la estrategia original. Lo cierto es que en un primer momento los consumidores disfrutan del beneficio que les proporciona los precios bajos, que no es más que una ventaja artificial, pues al largo plazo los consumidores tendrán que enfrentar el alza de los precios de venta.

Esta forma de entender los precios dumping ha sido muy difundida por la doctrina y si bien esta concepción es entendida teóricamente, no existe casuística alguna que ejemplifique su configuración en la realidad comercial:

La realidad económica de la finalidad predatoria es bastante cuestionable. Aunque sea teóricamente posible, su existencia real está condicionada a factores

13 El mercado monopólico se caracteriza por direccionar una gran demanda a un solo agente ofertante. En este caso, el proveedor es el único fijador de precios y establece las condiciones de transacciones. El ofertante deberá producir escasez para que sus precios sean altos. 
extremadamente complejos, que dependen no sólo de la conformación económica del importador, sino también de las características estructurales del mercado importador.

(Barral, 2010, pág. 11)

Además de ello, debe quedar claro que el elemento subjetivo relativo a la intención del exportador no va a ser tomado en cuenta por la autoridad administrativa dentro del procedimiento antidumping, pues el GATT y el Acuerdo Antidumping condicionan la aplicación de derechos antidumping una vez que converja la existencia de elementos objetivos tales como el margen dumping, daño y nexo causal ${ }^{14}$.

La intencionalidad supone dolo, elemento subjetivo que es muy difícil de probar, es por ello que se opta por el elemento objetivo como la existencia de un precio inferior artificial; ya que es difícil saber qué estaba en la mente del productor. En el caso del dumping no se ha dispuesto el requisito de la intensión (por parte del exportador) de causar un daño. Las normas antidumping no han considerado tal requisito; por lo que probar la práctica del dumping es mucho más fácil ya que no se tiene que determinar la existencia de intensión de dañar a la industria nacional. (Sotomayor Vértiz, 2003, pág. 50)

Por lo expuesto líneas arriba, nuestra posición consiste en descartar definir a los precios dumping como precios predatorios, pues los criterios que delimitan a ésta última no se ajusta al marco normativo ni a la realidad comercial que modela la práctica dumping.

\subsubsection{PRECIOS DUMPING COMO DISCRIMINACIÓN INTERNACIONAL DE PRECIOS:}

La discriminación de precios se configura en un escenario que se resume en la existencia de dos mercados geográficamente apartados, la venta de un mismo producto y la aplicación de precios distintos a los consumidores del país de origen y de destino.

$14 \quad$ Véase la páginas 27 y siguientes. 
Imaginemos que un productor vende cierto producto en su mercado interno a $\$ 10$. Con el propósito de diversificar sus ventas, éste decide exportar la misma mercancía a otro país; es lógico pensar que dicha transacción va a importar el incremento del precio para cuando se comercialice en el mercado de destino, pues el exportador deberá incurrir en costos correspondientes al transporte, seguro, flete, aranceles, gastos administrativos por nacionalización, entre otros. Tal incremento en los costos puede significar que el precio de exportación ascienda a $\$ 14$.

Sin embargo, la figura legal de discriminación de precios plantea una situación distinta en la que el exportador vende sus productos en el país importador a precios más bajos de los establecidos en el mercado de origen; es decir, el precio de exportación no sería \$14 sino \$8. En este caso, no existe un fundamento lógico que justifique la asimetría de precios, pues se trata de la comercialización del mismo producto, con igual calidad; se trata pues de una diferenciación arbitraria que perjudicará a los consumidores del país exportador porque serán ellos quienes soporten los efectos negativos de esta estrategia comercial. Por su parte, Sotomayor Vértiz (2003) distingue entre discriminación de mercados y productos:

La discriminación de precios puede realizarse vía mercados o vía productos. En el primer caso se trata de una práctica desarrollada por una misma empresa en dos o más mercados separados. Los consumidores de los distintos mercados no son tratados de igual forma, pues en uno de ellos se paga menos por el mismo bien. En el segundo caso existe una diferenciación no por medio de los mercados sino vía productos. La empresa discriminante oferta una variedad de bienes y/o servicios a distintos consumidores, algunos de ellos serán comercializados a precios inferiores al costo total promedio y generarán pérdidas, paralelamente otros productos ofertados por la empresa generarán ganancias. El resultado final de la práctica es una utilidad neta a favor de la empresa ya que ella ha abusado de los consumidores de un tipo de producto. (pág. 55) 
Recordemos que la discriminación de precios, como institución legal, es también regulada por el Derecho de Competencia, la cual reprime esta práctica cuando es realizada en el contexto de un mismo territorio nacional y es operada por un agente que se encuentra en posición de dominio. Con el propósito de precisar que tal práctica es realizada en el marco del comercio internacional, se va a definir a los precios dumping como una práctica de discriminación internacional de precios, esta terminología va a delimitar cuando se hace referencia a una discriminación de precios en un marco nacional normado por el Derecho de Competencia y cuando se trata de una discriminación de precios en un marco internacional normado por las normas antidumping.

\subsubsection{NUESTRA POSTURA:}

Por lo expresado líneas arriba, se entiende que los precios dumping no pueden ser ligados a los precios predatorios porque, por un lado, la intencionalidad del exportador no es un elemento tomado en cuenta durante el procedimiento antidumping y, por otro lado, la realidad comercial demuestra que es muy complejo, por no decir imposible, que converjan todas las condiciones que hagan posible la eliminación de todos los competidores en el país de destino, tornándolo en un mercado monopólico.

Mientras que resulta más viable definir a los precios antidumping como la realización de una práctica de discriminación internacional de precios en donde se introduce un producto al comercio de otro país mediante precios inferiores a los establecidos en el mercado de origen. En caso converjan todos los elementos necesarios para determinar que esta práctica debe ser reprimida, se deberán aplicar derechos antidumping que van a equilibrar los precios de exportación, de acuerdo a lo que va a ser considerado el valor normal, todo ello con el fin de proteger a la industria nacional.

Así, coincidimos con la definición planteada en el Informativo Caballero Bustamante (1997), en la cual se señala que el dumping es una: 
Consecuencia de conductas empresariales de penetración y posicionamiento de mercados externos mediante una discriminación de precios que supone la colocación de excedentes de producción en un mercado objetivo o la exportación de productos a costos variables, asumiendo la venta en el mercado local todos los costos fijo de fabricación. Es una práctica que afecta el comercio internacional en situaciones de libre competencia y por ello es necesario que el Estado cuente con mecanismos. (pág. H1)

\subsection{ORIGEN Y DESARROLLO DEL DUMPING}

En la medida en que las prácticas comerciales se han intensificado, en base a la apertura comercial; la integración entre países; la tecnología; los tratados internacionales; la globalización, entre otros elementos, se han venido desarrollando correlativamente conductas comerciales que buscan procurarse ventajas comerciales que pueden devenir en indebidas, como lo son las prácticas dumping.

Ante esta situación, de interés global, la OMC se pronunció sobre el tema, en razón de su importante rol como organización internacional, y procuró la participación de los países en el comercio internacional apoyados en un mercado que se basa en el libre comercio, fuera de distorsiones o actos desleales de comercio internacional, tales como el dumping, para ello, los países miembros debían subyugarse a las reglas establecidas en el GATT y el Acuerdo Antidumping.

Ante la manifestación normativa de la OMC todos los países miembros, entre ellos nuestro país, han implementado los lineamientos desarrollados por dicha organización internacional. A continuación, se verá la experiencia normativa antidumping de los Estados Unidos y Perú. 
Canadá fue el primer país que aplicó medidas antidumping en 1904. Posteriormente, Estados Unidos implementó dichas medidas a través de la Ley de Antidumping de 1916, sin embargo, las disposiciones de este cuerpo legal eran contrarias a las establecidas en el GATT. En 1998 el Órgano de Solución de Diferencias (en adelante la OSD) recibió una consulta realizada por la Unión Europea respecto a la correspondencia de la Ley de 1916 con la normativa establecida por la $\mathrm{OMC}^{15}$. Finalmente, se concluyó que la Ley norteamericana:

No aplicaba exclusivamente el criterio del daño establecido en el artículo VI del GATT, pues preveía la imposición del pago del triple de los daños causados, multas o penas privativas de libertad, en lugar de derechos antidumping, la Ley de 1916 infringía el párrafo 2 del artículo VI del GATT de 1994 y no establecía los diversos requisitos de procedimiento estipulados en el Acuerdo Antidumping.

(Organización Mundial de Comercio , 2004)

Debido a su corte penalista y a la discrepancia existente entre la Ley de 1916 y las reglas internacionales, en diciembre del 2004 el congreso de los Estados Unidos determinó su derogación. La primera ley antidumping con corte administrativo en Estados Unidos fue el Antidumping Act de 1921 que fue derogada por el Trade Agreements Act de 1979, la cual contiene modificaciones tales como el Tarrif Act de 1984, el Omnibus Trade and Competitiveness Act de 1988 así como los cambios realizados en razón de la Ronda de Uruguay.

En el caso peruano, la Comisión de Dumping y Subsidios es el ente que forma parte de INDECOPI y que está llamado a fiscalizar las prácticas comerciales y eliminar las distorsiones del mercado ${ }^{16}$ a través de un procedimiento antidumping ${ }^{17}$ si algún comportamiento recae sobre el supuesto de hecho determinado para los precios dumping.

\footnotetext{
15 Para más detalles sobre el caso, puede revisarse la diferencia DS136 en la página web de la OMC.

16 Artículo 2 del Decreto Legislativo $\mathrm{N}^{\circ}$ 1033.- Funciones del INDECOPI

b) Defender la libre y leal competencia, sancionando las conductas anticompetitivas y desleales y procurando que es los mercados exista una competencia efectiva;
} 
Igualmente, el 11 de enero de 2003 se publicó en el diario oficial El Peruano el Decreto Supremo Nº 006-2003-PCM, modificado por el Decreto Supremo No 004-2009PCM, destinado a reglamentar las normas previstas en el Acuerdo relativo a la aplicación del artículo VI del Acuerdo General sobre aranceles aduanero y comercio de 1994. Además de ello, el Texto Único de Procedimientos Administrativos contiene los requisitos pertinentes para la iniciación del procedimiento.

El propósito del derecho antidumping es fungir de un mecanismo que busca neutralizar las consecuencias desfavorables que puede causar una discriminación internacional de precios a la industria nacional del país importador. En este caso, se sustenta que la ratio legis que impulsa esta institución es la de procurar una simetría comercial, mas no puede considerarse ésta como fundamento de prácticas proteccionistas que obstaculicen la libre competencia internacional.

Hay autores que incluso señalan que el derecho antidumping no debería existir y se debería, más bien, fomentar las prácticas de competencia, permitiendo al mercado regular sus relaciones comerciales, sin embargo, difiero de este planteamiento y creo acertada la manifestación de la OMC al normar la práctica de dumping, pues lo que finalmente se busca es eliminar las distorsiones que generan en el mercado la práctica engañosa de los precios dumping.

\subsection{ELEMENTOS DEL DUMPING}

De la lectura de los preceptos del Acuerdo Antidumping se desprenden todos los elementos que deben concurrir para la determinación de prácticas dumping, éstos deberán

c) Corregir las distorsiones en el mercado provocadas por el daño derivado de prácticas de dumping y subsidios.

17 En la página web de Indecopi se señala que: "El procedimiento de investigación por prácticas de dumping (o procedimientos antidumping es un procedimiento administrativo a través del cual se determina si existen importaciones de mercancías en condiciones de discriminación de precios que causen daño, amenaza de daño o retraso a una rama de producción nacional en un periodo determinado. Si este es el caso, el procedimiento concluye con la aplicación de un derecho antidumping" (INDECOPI, (s.f.)) 
ser tomados en cuenta por la autoridad administrativa para poder aplicar, de forma legítima, los derechos antidumping:

\subsubsection{PRECIO DE EXPORTACIÓN}

Es el precio del producto que es introducido desde el mercado de origen al de destino y resulta ser inferior al valor normal. El valor de exportación figura normalmente en el Contrato de Compra Venta Internacional suscrito por el exportador e importador o, en su defecto, en la Factura Comercial; sin embargo, en caso no exista un precio de exportación o éste sea cuestionado, la autoridad del país importador deberá reconstruir dicho precio, calculado sobre la base del precio al que los productos importados se revendan por vez primera a un comprador independiente, según señala el artículo 2.3. del Acuerdo Antidumping.

Con respecto al INCOTERM que debe ser tomado en cuenta para la determinación del precio de exportación, Sotomayor Vértiz (2003) precisa que: “éste, si bien generalmente es FOB, podría ser otro precio en vista de las posibilidades que dan los INCOTERMS” (pág. 28).

\subsubsection{VALOR NORMAL:}

Será establecido por la autoridad competente durante el procedimiento administrativo para ser comparado con el precio de exportación que representa un valor distorsionado. Para tal propósito, el administrador cuenta con tres pautas determinadas por el artículo 2.2. del Acuerdo Antidumping: 
- El valor normal será el precio del producto similar $^{18}$ en el mercado interno del país exportador en el curso de operaciones comerciales normales.

- En caso existan alteraciones en el mercado o el bajo volumen de ventas dentro del mercado interno no permita una adecuada comparación, se tomará en cuenta el precio de un producto similar que sea exportado a un tercer país.

- En caso el segundo método no permita obtener un precio representativo, la autoridad deberá reconstruir el precio teniendo en cuenta el costo de producción así como los gastos administrativos, de venta y de carácter general.

\subsubsection{MARGEN DE DUMPING:}

Resulta de la diferencia entre el valor normal y el precio de exportación. Sin embargo, para la aplicación de derechos antidumping, no basta con haber fijado un margen de dumping, pues el Acuerdo Antidumping exige además que éste supere el test de minimis. El artículo 5.8 del Acuerdo considera minimis el margen de dumping cuando sea inferior al $2 \%$ del precio de exportación o cuando las importaciones objeto de dumping representan menos del 3\% de las importaciones totales del producto similar en el país importador. Solo en caso se supere el test de minimis, la autoridad podrá continuar con el análisis de los demás elementos en el marco de la investigación de dumping.

Para ejemplificar la relación matemática existente entre el valor normal, el precio de exportación y el margen de dumping se va a citar un caso ${ }^{19}$ correspondiente al Informe de Labores del 2014 de la Comisión de Dumping y Subsidios:

18 Según especifica el artículo 2.6. del Acuerdo Antidumping, se entenderá que la expresión "producto similar" significa un producto que sea idéntico, es decir, igual en todos los aspectos al producto de que se trate o, cuando no exista ese producto, otro producto que, aunque no sea igual en todos los aspectos, tenga características muy parecidas a las del producto considerado.

19 Para más detalle sobre el caso revisar la Resolución N 283-2013/CFD-INDECOPI que dispone los fundamentos que justifican el inicio del procedimiento antidumping. El caso está asignado al Expediente 0562013. 
Tubos y Perfiles Metálicos S.A. (en adelante TUPEMESA), empresa peruana con una participación del 28,7\% en la industria nacional, solicitó el inicio de un procedimiento antidumping respecto a las importaciones de tubos de acero laminado en caliente proveniente de la República Popular China. La Comisión dispuso el inicio de la investigación y determino que:

A partir de la comparación equitativa entre el valor normal (calculado sobre la base del valor de exportación de tubos de acero de China a Chile ${ }^{20}$ ) y el precio de exportación del producto chino al Perú, se encontró, para el periodo objeto de análisis del caso (mayo 2012 - abril 2013), un margen de dumping de 12,8\% en los envíos al Perú de tubos de acero procedentes de China.

(INDECOPI, 2014)

\section{Tabla 2.1.}

Existencia de precio dumping Tubos de Acero Laminado en Caliente

\begin{tabular}{|c|c|c|}
\hline Valor normal & Precio de exportación & Margen de dumping \\
\hline (US\$/tonelada) & (US\$/tonelada) & $12,8 \%$ \\
\hline 786 & 697,1 & \\
\hline
\end{tabular}

Fuente: ADUANAS, SICEX

Elaboración: ST-CFD/INDECOPI

En: https://www.indecopi.gob.pe/documents/51763/207639/1.-InformeLabores2014.pdf/0540c572-68624113-8d87-d7edb705a7

Como se observa el margen de dumping es expresado en porcentaje y en este caso supera el porcentaje de minimis, por tanto, la Comisión puede continuar analizando los demás elementos requeridos para aplicar o no los derechos antidumping.

En este caso, se observa que no se determinó el precio de exportación de acuerdo a las ventas del producto similar en el mercado interno del país exportador (China), sino que se estableció el margen de dumping mediante la comparación con un precio comparable del producto similar cuando éste fue exportado a un tercer país (Chile). Ello puede responder a una situación especial del mercado chino o a un bajo volumen en las ventas en el mercado interno del país exportador. 


\subsubsection{DAÑO O AMENAZA DE DAÑO:}

El artículo 3 del Acuerdo Antidumping establece los tres criterios que deben ser tomados en cuenta para determinar la existencia de daño.

- La Comisión deberá comprobar si el volumen de importaciones ha aumentado significativamente respecto al periodo de investigación.

- La autoridad deberá confirmar los efectos que ha generado las importaciones en los precios de la industria nacional, es decir, si la práctica dumping ha provocado que se reduzcan significativamente los precios del producto similar o ha imposibilitado el alza de los precios que en otro caso se hubiera producido.

- La Comisión deberá concluir si las importaciones sujetas a la investigación antidumping ha derivado en el detrimento en la rama de producción nacional, para ello se deberá analizar determinados elementos e índices económicos establecidos en el numeral 3.4. del Acuerdo Antidumping ${ }^{21}$.

Por otro lado, para determinar la existencia de una potencial amenaza de daño que precise la aplicación de mecanismos antidumping, la OMC dispone la concurrencia de los siguientes requisitos:

- Circunstancias claras y hechos reales que demuestren el inminente incremento del volumen de las importaciones.

21 Artículo 3.4. del Acuerdo Antidumping: El examen de la repercusión de las importaciones objeto de dumping sobre la rama de producción nacional de que se trate incluirá una evaluación de todos los factores e índices económicos pertinentes que influyan en el estado de esa rama de producción, incluidos la disminución real y potencial de las ventas, los beneficios, el volumen de producción, la participación en el mercado, la productividad, el rendimiento e las inversiones o la utilización de la capacidad; los factores que afecten a los precios internos; la magnitud del margen de dumping; los efectos negativos reales o potenciales en el flujo de caja, las existencias, el empleo, los salarios, el crecimiento, la capacidad de reunir capital la inversión. Esta enumeración no es exhaustiva, y ninguno de estos factores aisladamente ni varios de ellos juntos bastarán necesariamente para obtener una orientación decisiva. 
- La consolidación de la capacidad exportadora del agente económico del país de origen que permita incrementar sus exportaciones al país de destino.

- La probabilidad de generar la reducción de los precios del producto similar en el mercado de importación o impedir su subida.

- Las existencias del producto objeto de la investigación.

Para ejemplificar la importancia del daño como uno de los criterios determinantes para la aplicación de derechos antidumping, se va a citar un caso $^{22}$ correspondiente al Informe de Labores del 2010 de la Comisión de Dumping y Subsidios:

Corporaciones Rey S.A., empresa peruana, denuncia la presunta existencia de precios dumping respecto a importaciones de cierres y cremalleras provenientes de Taiwán. La Comisión de Dumping, Subsidios y Eliminación de Barreras no Arancelarias, autoridad encargada para conocer y resolver sobre estos casos, admite a trámite la denuncia e inicia el procedimiento administrativo que finaliza con la decisión de no aplicar derechos antidumping, pues de la investigación realizada se observa que dichas importaciones no generan daño a la industria nacional. Si bien se estableció la existencia de un margen de dumping del $37 \%$ para los cierres de metal y $59 \%$ para los demás cierres, superándose el requisito del minimis, la Comisión concluyó que ello no generaba daño alguno en la rama de producción nacional, pues el volumen de las importaciones objeto de las investigaciones antidumping se habían reducido, las importaciones taiwanesas del producto en cuestión no obligó la reducción de los precios del producto similar ni impidió su alza y no se comprobó alguna repercusión negativa de las importaciones sobre los productores nacionales. Por tanto, la Comisión no aplicó derechos antidumping y emitió una resolución estableciendo los fundamentos que impulsaron la improcedencia de la solicitud.

22 Para más detalle sobre el caso revisar la Resolución N 224-2010/CFD-INDECOPI, emitida el 22 de diciembre del 2010 que dispone la conclusión del procedimiento antidumping, la cual rechaza la solicitud presentada por la empresa peruana, negando la aplicación de medidas antidumping. 
Como se puede ver el rol de la Comisión consiste en analizar todos los elementos requeridos por la normativa internacional, basta que no se configure alguno de los requisitos para que se determine la no aplicación del mecanismo antidumping.

El procedimiento antidumping y los lineamientos establecidos por el GATT y el Acuerdo Antidumping son tan precisos que su correcta aplicación por la autoridad administrativa va a evitar caer en actos proteccionistas, pues el principal propósito del derecho antidumping es eliminar las distorsiones del mercado.

\subsubsection{NEXO CAUSAL:}

El numeral 3.5 del Acuerdo Antidumping hace referencia a la relación causal que debe existir entre la práctica dumping y el daño a la rama de la producción nacional. La Comisión de Dumping, Subsidios y Barreras no Arancelarias deberá analizar todos los elementos que causan detrimento a los productores del país importador correspondientes a los precios dumping y diferenciarlos de los elementos exógenos que puedan repercutir negativamente en las operaciones de la industria nacional. Si tras la investigación se determina que el daño responde exclusivamente a los precios dumping, entonces se aplicarán derechos antidumping.

A continuación se presenta un caso recibido en segunda instancia por el Tribunal de Indecopi, el cual conoce sobre el reclamo interpuesto por la empresa productora nacional Compañía Universal Textil S.A. (en adelante CUTSA) en contra de las importaciones realizadas por empresas indias de tejidos mezcla de poliéster y rayón viscosa. El Tribunal confirma la Resolución $N^{\circ}$ 038-2011/CFD-INDECOPI, emitida en

primera instancia por la Comisión, que aplica derechos antidumping definitivos sobre las importaciones indias, debido a que se confirmó la existencia de margen dumping entre los precios de exportación y el valor normal; además se acreditó la causación de un daño al productor nacional, pues éste presentó una reducción en sus ventas, utilidades y 
participación en el mercado local. Ahora bien, con respecto al nexo causal, el Informe de labores del 2013 señala que:

Se verificó la existencia de una relación causal entre la práctica de dumping y el importante daño registrado por la rama de producción nacional, reflejado en el incremento relevante del volumen de las importaciones objeto de dumping y su mayor presencia en el mercado interno durante el periodo de investigación, no habiéndose constatado la existencia de otros factores, distintos a dichas importaciones que pudieran haber generado o contribuido al daño experimentado por la rama.

(INDECOPI, 2014, pág. 130)

Como se puede ver de los casos presentados, la práctica del dumping no está prohibida de plano y, en el sistema peruano, la Comisión de Dumping y Subsidios deberá analizar todos los elementos requeridos para demostrar la realización de un acto desleal de comercio internacional que deberá ser reprimido mediante la aplicación de medidas antidumping, evitando actuar fuera de los lineamientos de la normativa nacional e internacional para que su accionar no sea calificado de proteccionista.

\subsection{MODALIDADES DEL DUMPING}

El estudio de los precios dumping ha permitido identificar diversas categorías mediante las cuales se ejecuta esta práctica, entre ellas podemos identificar el dumping ocasional, dumping social, dumping ecológico y dumping de elusión:

\subsubsection{DUMPING OCASIONAL:}

Es considerado un tipo de dumping circunstancial que se genera debido al sobre almacenamiento de productos que no han podido ser consumidos en su totalidad por los 
usuarios del mercado interno, por tanto, el excedente existente será exportado a un mercado externo a precios inferiores de los aplicados en el mercado de origen. Algunos autores consideran que por tratarse de una práctica a corto plazo no acarrearía implicancias negativas a la rama de producción nacional del país importador.

\subsubsection{DUMPING SOCIAL:}

En este caso, la discriminación internacional de precios es posible en la medida en que los países, principalmente los subdesarrollados, no incurren en costos adicionales correspondientes a beneficios sociales adscritos a sus trabajadores. Mientras que la normativa laboral es más rigurosa en el sistema legal de países desarrollados, generando el incremento de sus costos fijos.

Sin embargo, comparto la postura de Sotomayor Vértiz (2003) quien señala que no es posible hablar de un dumping social, pues los costos laborales forman parte del costo fijo final que será igualmente incluido en los costos de venta nacionales y el valor de exportación:

El dumping social no toma en cuenta que el costo fijo por concepto de remuneraciones es el mismo para el producto de consumo doméstico y el que es exportado; por lo que no hay tal discriminación de precios entre dos mercados distintos (presupuesto para que se pueda hablar de dumping). (pág. 88)

\subsubsection{DUMPING ECOLÓGICO:}

Hay países que tienen una legislación muy permisiva respecto al Derecho Ambiental, ello es aprovechado por los productores nacionales, pues les permite reducir costos frente a otros países que incurren en mayores costos con el fin de cumplir normativa 
ambiental más estricta. Esta ventaja les permite exportar el producto a un precio menor del establecido en el mercado de destino, generándose una ventaja indebida.

Sin embargo, al igual que en dumping social, no se configura una discriminación internacional de precios en la medida de que los costos medioambientales van a ser disgregados igualmente en el precio de venta nacional y de exportación. Asimismo, el argumento medioambiental escapa de los alcances de la regulación antidumping por no ser materia de regulación.

\subsubsection{DUMPING DE ELUSIÓN:}

Vamos a referirnos a este tipo de dumping brevemente, pues por ser materia de la presente investigación, será analizada en los siguientes capítulos. Se trata de una práctica relativamente reciente que se ha configurado como respuesta al incremento en la aplicación de derechos antidumping.

La casuística demuestra que las prácticas elusivas son frecuentemente aplicadas por los países asiáticos y consiste en el cambio en las condiciones de exportación que se usó en un inicio y que formó parte de la investigación antidumping. Las diferentes modalidades elusivas van a permitir salirse del parámetro de aplicación de los derechos antidumping, siendo improbable su aplicación. Al respecto, países como Estados Unidos, la Unión Europea, entre otros han concluido en la necesidad de legislar en contra del dumping elusivo; más adelante se determinará la conveniencia en el caso peruano de reglamentar frente a las prácticas de elusión.

A pesar de que la doctrina reconoce otras modalidades de dumping, las cuales se constituyen principalmente como estrategias de marketing, tales como el dumping cíclico, de penetración, defensivo, por anticipado, entre otros ${ }^{23}$; es importante precisar que no es

23 En el Análisis de las funciones del INDECOPI a la luz de las decisiones de sus órganos resolutivos, se cita los tipos de dumping identificados: 
parte del proceso administrativo diferenciar el tipo de dumping que está siendo practicado, por tanto, la discusión respecto a las modalidades de dumping tienen un corte netamente teórico porque en la práctica no es un criterio a ser tomado en cuenta. "La reglamentación antidumping no diferencia el tipo de dumping que está siendo practicado, a efectos de evaluar la legitimidad de la aplicación de las medidas correspondientes” (Barral, 2010, pág. $5)$.

\subsection{LOS PRECIOS DUMPING Y OTRAS FIGURAS JURÍDICAS}

La difusión en la aplicación de las medidas antidumping ha impulsado el análisis de los precios dumping. Este estudio ha generado que se equipare al dumping con otras instituciones que tienen rasgos, condiciones y criterios distintos. Con arreglo a ello, el objetivo del siguiente acápite consiste en discutir abuso de posición de dominio, dumping interno y salvaguardias:

\subsubsection{ABUSO DE POSICIÓN DE DOMINIO:}

En primer instancia, debemos tener en cuenta que, a diferencia del dumping, el abuso de posición de dominio se encuentra regulada en otro cuerpo normativo y no en el

- Dumping cíclico: Tiene como finalidad estabilizar la producción sobre el ciclo de negocios. Busca cubrir los costos fijos y variables o asegurar el pago de las prestaciones sociales. Suele estar motivado por el deseo de deshacerse de stock excesivos o para garantizar puestos de trabajos en periodos de baja demanda.

- Dumping de penetración: Es el que se emplea cuando la sensibilidad de los precios en el mercado de exportación permite utilizar economía a escala, lo que facilitará el ir aumentando simultáneamente la demanda y los niveles de producción, o costos decrecientes.

- Dumping defensivo: Implica una disminución en los precios de exportación en un determinado segmento del mercado con el objeto de impedir la entrada de potenciales competidores. Se aplica sobre todo cuando los mercados a donde se dirige la producción se hallan en un estado de contracción de demanda.

- Dumping por anticipado: También conocido como Early Arrival, se da cuando el productor busca impedir la entrada de futuros competidores. Es muy común en la industria de la alta tecnología cuando el productor planea invadir el mercado con productos de tecnología de punta con precios difíciles de igualar por otras empresas que no se encuentran en su posición de liderazgo

(Calmet Mujica, 2013, pág. 19) 
D.S. $\mathrm{N}^{\circ}$ 006-2003-PCM. Además de ello, esta institución supone la aparición de específicos supuestos para incurrir en prácticas explotativas ${ }^{24}$ o prácticas exclusorias ${ }^{25}$ :

- Mercado relevante: con un doble aspecto, en primer lugar, hace referencia a la región geográfica en el que se comercializa el producto sustituto de la mercancía relevante (mercado geográfico) y, por otro lado, se hace incidencia respecto a los bienes o servicios alternativos a los que el consumidor puede recurrir (mercado de producto).

- Porcentaje de participación: el volumen de ventas de los agentes económicos va a ayudar a determinar el porcentaje de participación que se tiene en el mercado interno.

- Concentración: de la oferta existente en el mercado.

- Existencia de barreras de entrada: que impidan o dificulten la participación de potenciales competidores en el mercado.

Sin embargo, los criterios antes mencionados no son elementos que configuren la aplicación de precios de discriminación internacional y, como se explicó líneas arriba, la posición de dominio no es un criterio analizado en el procedimiento antidumping.

\subsubsection{DUMPING INTERNO:}

El pronunciamiento normativo de la OMC se ha realizado y adscrito exclusivamente al dumping internacional, mas no al interno, pues la intención es regular de forma general una práctica desarrollada en un marco externo en donde se ejecutan prácticas de comercio exterior, escenario en donde participan diversos operadores supranacionales. Por otro lado, el dumping interno será regulado específicamente por cada derecho interno,

\footnotetext{
24 Son prácticas abusivas aplicadas a los consumidores del producto producido por el agente económico con posición de dominio.

25 Son prácticas abusivas aplicadas a competidores potenciales o existentes, eliminando a los competidores o impidiendo que éstos accedan al mercado.
} 
dependiendo de las condiciones del mercado interno, de sus precios y del marco económico.

En la normativa peruana, el dumping interno se constituye como un supuesto de abuso de posición de dominio, por tanto, está práctica será reprimida de acuerdo a las condiciones establecidas por el Derecho de Competencia y no por la normativa antidumping.

\subsubsection{SALVAGUARDIAS:}

Las medidas de salvaguardias son aplicadas en contra de las importaciones de determinado producto que han aumentado de tal manera que genera un daño o una amenaza de daño en la rama de producción nacional del país de importación que produce el producto similar. Como bien se precisa a continuación:

La finalidad de la salvaguardia es que los productores nacionales se ajusten a esta competencia inesperada durante el periodo de tiempo que se apliquen. A diferencia de los derechos antidumping y compensatorios, para aplicar una salvaguardia no se necesita demostrar que existe una práctica de dumping o una subvención, pero los productores nacionales deben presentar antes de su aplicación un plan de reajuste que refleje de qué manera se adecuarán a la competencia de las importaciones. (INDECOPI, (s.f.))

A nivel internacional, la OMC ha emitido el Acuerdo sobre Salvaguardias Nuestra posición se desarrolla acorde con la siguiente proposición y, a nivel nacional, se aplica el Decreto Supremo No 020-98-ITINCI que aprueba normas reglamentarias de los Acuerdos sobre Salvaguardias y de Textiles y Vestido de la Organización Mundial del Comercio, el cual ha sido modificado Decreto Supremo N $017-2004-M I N C E T U R$. 
Según la normativa vigente, el procedimiento administrativo se concentra en determinar la existencia de daño o amenaza de daño y un nexo causal entre el aumento de las importaciones del producto, materia de la investigación, y el daño al que se hace referencia. A diferencias de otras medidas no arancelarias, la autoridad no incluye dentro del procedimiento una investigación por precios dumping o subvenciones. Es decir, no se requiere el análisis de una conducta o la ejecución de una práctica desleal.

Una vez culminada la investigación y en caso la autoridad así lo determine se podrán aplicar medidas de salvaguardias, las cuales se constituyen como instrumentos de urgencia.

Por lo antes visto, se concluye que el dumping es una práctica que se realiza en un marco de transacciones internacionales, así por ser de interés global su regulación no puede equipararse al dumping que se genera en un escenario interno. Además, no puede confundírsela con el abuso de posición de dominio en la medida en que el supuesto generador de cada institución responden a elementos y características distintas que no permite equiparar estos elementos, sino más bien diferenciarlos. Además, el abuso de posición contractual en ningún caso es permitido por la autoridad administrativa, sin embargo, el dumping no está prohibido de plano, pues se tendrá que analizar la concurrencia de los requisitos establecidos por el GATT y Acuerdo Antidumping. 


\section{Capítulo III}

\section{DERECHOS ANTIDUMPING}

\subsection{NATURALEZA JURÍDICA DEL DERECHO ANTIDUMPING}

La OMC ha otorgado la prerrogativa a la autoridad competente de los países miembros para la aplicación de derechos antidumping como un mecanismo que busca equilibrar los precios de exportación a un valor normal que genere una correcta competencia en el mercado interno del país importador. Ahora bien, antes de ingresar al meollo del procedimiento administrativo que permite la aplicación de derechos antidumping a importaciones que realizan discriminación internacional de precios, conviene precisar, en primera instancia, la naturaleza jurídica de los derechos antidumping para así entender mejor su contenido y propósito.

\subsubsection{DERECHO ANTIDUMPING COMO TRIBUTO:}

En un momento, se equiparó la naturaleza jurídica del derecho antidumping con la de los tributos, sin embargo, ello no es así. Recordemos que si bien no existe una definición expresa de lo que es tributo, la doctrina ha desarrollado una serie de características que encierra su definición:

- La aplicación y recaudación de los tributos se realizan en razón de la supremacía que detenta la Entidad Pública sobre los administrados, ello implica la manifestación del Estado a través de su ius imperium con el fin constreñir a los 
particulares a la realización de la prestación de los tributos. Se puede concluir entonces que los ingresos percibidos son de carácter público.

- Una vez que se configure el supuesto de hecho que desencadena la aparición de la obligación tributaria, el pago de los tributos por parte del administrado se torna obligatoria.

- Los tributos son establecidos por Ley, al respecto el autor Vega Billán (1999) señala que: "Este es el requisito sine qua non sin el cual no puede imponerse ningún tributo; viene a ser el límite formal para la imposición de los tributos. Se encuentra consagrado (...) por el Principio de Legalidad, que está expresado en el aforismo latino "Nullum tributum sine lege”. (pág. 58)

- La creación y aplicación de los tributos se rige bajo el principio de la capacidad contributiva. "La potestad normativa tributaria de la que goza el legislador encuentra un límite material en este singular principio. Su reconocimiento como valor constitucional permite garantizar cargas tributarias apegadas a la aptitud contributiva del sujeto" (García Bueno, 2009, pág. 57).

- El tributo "consiste en una prestación pecuniaria; es decir, se fundamentan en la obligación de entregar una suma de dinero a una Administración Pública. Así los tributos solo pueden ser pagados en efectivo, crédito que será cobrado, en el caso peruano, a través de la cuenta de detracciones o la cuenta por cobrar de SUNAT” (Collado Yurrita, 2009, pág. 154).

- El Estado aplica su facultad de coertio con el objetivo de captar ingresos para la financiación de sus gastos. "La finalidad primordial del tributo es allegar recursos al ente público a cuyo favor nace la obligación pecuniaria en la que se manifiestan para cumplir las finalidades que le son propias" (Collado Yurrita, 2009, pág. 154).

Estas son pues las principales características reconocidas a la figura jurídica del tributo, aunque cabe precisar que la doctrina ha desarrollado variados criterios en torno a ella. Ahora bien, a continuación, se analizará la correspondencia que pudiera existir entre estas características y el derecho antidumping. 
En primera instancia, importa señalar que una vez configurado los supuestos establecidos por el Acuerdo Antidumping, el país de importación, a través de la autoridad competente, tiene la prerrogativa de equilibrar dicha situación mediante la aplicación del derecho antidumping, ello después de un proceso administrativo que así lo determine. Si ello resultare así la cancelación del derecho antidumping se tornará obligatoria, siempre que el importador quiera nacionalizar las mercancías traídas al mercado doméstico.

En nuestro país, una vez que la Comisión de Dumping, Subsidios y Eliminación de Barreras no Arancelarias del INDECOPI concluye un procedimiento administrativo con la aplicación de derechos antidumping, se le comunicará al respecto a Aduanas quien se encargará de realizar la cobranza de dichos derechos ${ }^{27}$.

Importa precisar que la finalidad que promueve el INDECOPI a través de la aplicación del derecho antidumping es la de eliminar las distorsiones creadas en las transacciones internacional y procurar una situación simétrica entre los actores comerciales, evitando posibles daños a una rama de producción nacional de la industria interna; mas la intención, a diferencia de los tributos, no es recaudadora. "La finalidad del derecho antidumping no es procurar al Estado ingresos para desarrollar actividades económico- sociales, sino proteger a una determinada industria nacional de importaciones declaradas como objeto de dumping" (Informativo Caballero Bustamante, (s.f.)).

En segundo lugar, la normativa antidumping a nivel nacional ha sido desarrollada mediante Decreto Supremo, emitido por el Ejecutivo y los derechos antidumping se cimientan en principios establecidos en los Acuerdos Internacionales, tales como la Cláusula de la Nación Más Favorecida y Trato Nacional Principio, por lo que, el principio de capacidad contributiva no es un elemento considerado. En este extremo estriba una de las diferencias que contrasta estas dos figuras.

27 Artículo 55 del Decreto Supremo N ${ }^{\circ}$ 006-2003-PCM. - Entidad encargada del cobro de derechos antidumping y compensatorios:

Aduanas es la entidad competente para efectuar el cobro de los derechos antidumping y compensatorios que establezca la Comisión, de conformidad con las disposiciones contenidas en el presente Reglamento. 
Como el lector podrá apreciar las características que delimitan al tributo no son las mismas de las que configuran al derecho antidumping, por ello, devendría en errónea la hipótesis de equiparar los criterios que definen a ambas instituciones jurídicas. Los fundamentos reseñados líneas arriba son además respaldados por el artículo 46 del Reglamento Antidumping, cuyo texto niega el carácter de tributo de los derechos antidumping ${ }^{28}$.

Es evidente entonces que el derecho antidumping no tiene naturaleza tributaria, ello porque no le son intrínsecas las particularidades de aquél y porque así lo determina de forma específica el Reglamento Antidumping. Ahora, pasaré a analizar otros criterios que podrían explicar la naturaleza jurídica aplicable al derecho antidumping.

\subsubsection{DERECHO ANTIDUMPING COMO MULTA:}

Diversos dispositivos legales se han referido a los derechos antidumping como multa, así lo hace, por ejemplo, el Reglamento Antidumping y el Informe N 026-2007SUNAT/2B0000. Por un lado, si bien el artículo 46 del Decreto Supremo ha negado inicialmente la naturaleza jurídica de tributo a los derechos antidumping, por otro, esta misma disposición le ha atribuido a aquella naturaleza de multa.

Bajo la misma línea, el Informe $\mathrm{N}^{\circ}$ 026-2007-SUNAT/2B0000 señala que el derecho antidumping no es una sanción pecuniaria derivada de una infracción aduanera, pues es otra la entidad pública que la impone: "Dichos derechos antidumping no se encuentran incluidos dentro de la definición de multa establecida en el Glosario de Términos Aduaneros, al no haberse verificado la violación de normas aduaneras y, por tanto, no forman parte del concepto de deuda tributaria aduanera”. Así concluye que

\footnotetext{
28 Artículo 46 del Decreto Supremo N 006-2003-PCM.- Naturaleza jurídica de los derechos
} definitivos:

Los derechos antidumping así como los derechos compensatorios, son medidas destinadas a corregir las distorsiones generadas en el mercado por las prácticas de dumping y subvenciones. En aplicación de lo dispuesto por el párrafo 1 del artículo 18 del Acuerdo Antidumping y el párrafo 1 del artículo 32 del Acuerdo sobre Subvenciones, no podrá aplicarse a estas prácticas ninguna otra medida que no sean los derechos antidumping o compensatorios, según sea el caso.

Los derechos antidumping así como los derechos compensatorios, provisionales o definitivos tienen la condición de multa y no constituyen en forma alguna tributo.

Los derechos antidumping o compensatorios, provisionales o definitivos, no están sujetos a rebajas, descuentos por pronto pago, ni beneficios de fraccionamiento o de naturaleza similar. 
"los derechos antidumping constituyen multas de carácter administrativo que establece la Comisión de Dumping y Subsidios del INDECOPI”. (SUNAT, 2007)

Sin embargo, esta aseveración tampoco tiene fundamento, ello en la medida en que la multa es una sanción administrativa que deviene de un actuar ilícito, un comportamiento que se aparta o está prohibido por el marco normativo. Ahora bien, preguntémonos entonces ¿Los precios dumping han sido prohibidos per se por la normativa internacional o, a nivel interno, a través del Reglamento Antidumping?, ¿el hecho de exportar productos con precios dumping implica de forma liminar la existencia de un acto ilícito? En ambos casos la respuesta es evidentemente negativa. Como ya se señaló líneas arriba, la OMC no prohíbe exportar un producto con precios dumping; lo que no es aceptable es escudarse en la discriminación internacional de precios para generar un daño, amenaza de daño o retraso sensible en la creación de una rama de producción nacional.

En esa medida, no se debe confundir la naturaleza jurídica del derecho antidumping con la multa, pues se tratan de instituciones cuyas génesis son evidentemente distintas. Así, mientras que por un lado la multa encuentra su origen en conductas ilícitas; el derecho antidumping proviene de un supuesto de hecho que no está prohibido por la ley.

De este modo, cuando se habla de derechos antidumping se debe entender que se hace alusión a un mecanismo usado por la administración en un marco de transacciones comerciales internacionales cuya finalidad es intervenir con el objetivo de estabilizar las posibles situaciones de competencia desleal por parte del país exportador que busca arraigar sus productos en un país de destino con el solo propósito de desestabilizar su producción. De este modo, mediante la aplicación del derecho antidumping que va a recaer sobre el margen de dumping se procurará nivelar el precio de exportación, evitando así las amenazas de desmedro industrial. 


\subsection{Procedimiento antidumping en el Perú}

Como ya se señaló en los capítulos anteriores, el Derecho Antidumping tiene su origen en el Acuerdo General sobre Aranceles y Comercio GATT de 1947, entendida correlativa y conjuntamente con el Acuerdo General sobre Aranceles y Comercio GATT de 1994 y complementada con el Acuerdo Relativo a la Aplicación del Artículo VI del Acuerdo General sobre Aranceles Aduaneros y Comercio de 1994, documento que establece los lineamientos requeridos para los procedimientos antidumping que deberán ser implementados en la legislación interna de los países miembros. Toda esta legislativa internacional fue una respuesta a la coyuntura comercial generada por la discriminación internacional de precios provocada tras la liberalización comercial.

En el marco nacional peruano, la normativa aplicable a conductas dumping consiste en el Decreto Supremo $\mathrm{N}^{\circ}$ 133-91-EF, modificado por el Decreto Supremo $\mathrm{N}^{\circ}$ 051-92-EF que establecen normas para evitar y corregir las distorsiones de la competencia en el mercado generadas por el dumping y es aplicable a los países no miembros de la OMC. Por otro lado, el Decreto Supremo N ${ }^{\circ}$ 006-2003-PCM, modificado por el Decreto Supremo $N^{\circ}$ 004-2009-PCM ha sido emitido para reglamentar las normas previstas en el Acuerdo relativo a la aplicación del artículo VI del Acuerdo General sobre Aranceles Aduaneros y Comercio 1994 y es aplicado a los países miembros de la OMC.

Si bien es cierto que, en principio, ni el numeral 1 del Artículo VI del GATT ${ }^{29}$ ni el artículo 2.1 del Acuerdo Antidumping ${ }^{30}$ prohíben de forma liminar la utilización de

$29 \quad$ Artículo VI.- Derechos antidumping y derechos compensatorios

1. Las partes contratantes reconocen que el dumping, que permite la introducción de los productos de un país en el mercado de otro país a un precio inferior a su valor normal, es condenable cuando causa o amenaza causar un daño importante a una rama de producción existente de una parte contratante o si retrasa de manera importante la creación de una rama de producción nacional (...).

$30 \quad$ Artículo 2.- Determinación de la existencia de dumping

2.1. A los efectos del presente acuerdo, se considerará que un producto es objeto de dumping, es decir, que se introduce en el mercado de otro país a un precio inferior a su valor normal, cuando su precio de exportación al exportarse de un país a otro sea menor que el precio comparable, en el curso de operaciones comerciales normales, de un producto similar destinado al consumo en el país exportador. 
precios dumping en la prácticas comerciales, no es menos cierto que se reprocha el ampararse en la utilización de este mecanismo con la finalidad de generar un daño en una rama de la industria nacional o por lo menos amenazar con generarlo.

En esta medida y con el propósito de que nuestro país no sufra las peligrosas consecuencias de los precios dumping, se ha delegado a la Comisión de Dumping, Subsidios y Eliminación de Barreras no Arancelarias del Instituto Nacional de la Defensa de la Competencia y de la Protección de la Propiedad Intelectual - INDECOPI la facultad de controlar el correcto accionar comercial. Así, en caso existan elementos probatorios suficientes que pongan en manifiesto la existencia de una práctica dumping; la causación de daño, amenaza de daño o retraso sensible a la creación de una rama de producción nacional y se concluya que existe una relación causal entre el daño y las importaciones objeto de investigación, el INDECOPI, a través de la Comisión, estará llamado a realizar un procedimiento destinado a analizar los elementos del caso y determinar si finalmente resulta conveniente equilibrar dicha situación comercial mediante la aplicación de derechos antidumping.

Según el Reglamento Antidumping ${ }^{31}$, la Comisión tendrá un plazo de 9 meses para la finalización del procedimiento administrativo de investigación antidumping, este plazo se computará desde la fecha de publicación de la Resolución Inicial en el Diario Oficial El Peruano. Cabe precisar que es posible que la Comisión determine una prórroga de 3 meses adicionales, siempre que los aplique durante la etapa probatoria. Por su parte, el numeral 5.10 del Acuerdo Antidumping otorga un plazo máximo de 18 meses para la conclusión del procedimiento antidumping.

A continuación, se mencionarán a los sujetos que participan de forma activa en la investigación antidumping para después analizar todas las etapas que comprende el procedimiento administrativo en el Perú a la luz de las disposiciones del Reglamento Antidumping, tales como: inicio del procedimiento, remisión y absolución de cuestionarios, periodo probatorio, hechos esenciales y fin del procedimiento.

$31 \quad$ Véase el artículo 32 del Reglamento Antidumping. 


\subsubsection{SUJETOS QUE PARTICIPAN EN EL PROCEDIMIENTO ANTIDUMPING:}

En el procedimiento antidumping confluyen los intereses de partes interesadas que participan dentro de éste ${ }^{32}$.

- LA COMisión: En el Perú, la autoridad competente para conocer las solicitudes de investigación de precios dumping es la Comisión de Dumping, Subsidios y Eliminación de Barreras no Arancelarias del INDECOPI.

Según el artículo 36 del Decreto Legislativo 1033, Reglamento de Organización y Funciones del Instituto Nacional de Defensa de la Competencia y de la protección de la Propiedad Intelectual - INDECOPI, Las Comisiones que la comprenden son órganos colegiados encargados de resolver, en primera instancia administrativa, los asuntos concernientes a las leyes del ámbito de su competencia. Para el ejercicio de su función resolutiva gozan de autonomía técnica y funcional.

El artículo 43 del mismo cuerpo legal precisa que la Comisión tiene a su cargo velar por el cumplimiento de las normas que persiguen evitar y corregir el daño en el mercado provocado por prácticas de dumping o subsidios, a través de la imposición de derechos antidumping o compensatorios, conforme a lo dispuesto en los acuerdo internacionales suscritos por el Perú, las normas de la OMC, los acuerdos de libre comercio y las normas supranacionales y nacionales vigentes sobre la materia.

32 Artículo 6.11 del Acuerdo Antidumping: A los efectos del presente Acuerdo, se considerarán "partes interesada":

1. Los exportadores, los productores extranjeros o los importadores de un producto objeto de investigación, o las asociaciones mercantiles, gremiales o empresariales en las que la mayoría de los miembros sean productores, exportadores o importadores de ese producto;

2. El gobierno del Miembro exportador; $y$

3. Los productores del producto similar en el Miembro importador o las asociaciones mercantiles, gremiales o empresariales en las que la mayoría de los miembros sean productores del producto similar en el territorio del Miembro importador.

Esta enumeración no impedirá que los Miembros permitan la inclusión como partes interesadas de partes nacionales o extranjeras distintas de las indicadas supra. 
La Comisión, después de verificar la configuración de los requisitos esgrimidos por la normativa antidumping, podrá decidir aplicar derechos antidumping provisionales y definitivos.

Para que la autoridad pueda decidir adoptar derechos antidumping provisionales deberán converger los siguientes supuestos. En primer lugar, debe establecerse una determinación preliminar positiva sobre la posible existencia de dumping, daño y relación causal. Asimismo, la aplicación de la medida debe ser necesaria para impedir que se genere un daño irreparable durante el curso de la investigación $\mathrm{y}$, finalmente, la investigación antidumping debe realizarse en concordancia con las disposiciones del Reglamento Antidumping. Las medidas provisionales podrán ser fijadas 60 días hábiles después de iniciado el procedimiento administrativo.

Por su parte, la Comisión podrá disponer la aplicación de derechos antidumping definitivos una vez terminado el procedimiento, con la Resolución que pone fin a éste. La medidas antidumping podrán tener una vigencia máxima de 05 años, en la medida que subsista el daño a la rama de producción nacional.

- RAMA DE PRODUCCIÓn NACIONAL: Como bien señala el artículo 20 del Reglamento Antidumping, se refiere al conjunto de productores nacionales del producto similar objeto de la investigación antidumping. Sin embargo, no se considerará dentro de esta noción a los productores quienes estén vinculados con los exportadores del país extranjero o a los importadores del producto sobre el cual se presume existe una práctica dumping.

Los criterios que serán tomados en cuenta por la autoridad para determinar la vinculación serán los siguientes: si uno de los agentes comerciales controla directa o indirectamente a otro; si ambos están controlados por una tercera persona directa o indirectamente; la vinculación provoca, en el productor nacional, una conducta comercial distinta al resto de productores que no detentan una situación de vínculo. 
Para iniciar un procedimiento administrativo de investigación antidumping se requiere que una parte significativa de la producción nacional de la rama de producción nacional del producto similar, sobre el que se trata, interponga la denuncia en contra del exportador del país extranjero. Es decir, como bien prescribe el artículo 21, se requiere una representación de por lo menos un $25 \%$

- IMPORTADOR: Es el agente comercial que se opera en el país de destino, es decir, en el lugar donde la autoridad administrativa desarrolla el procedimiento administrativo antidumping.

La conducta del importador no es en todos los casos desleal, pues éste no está obligado de conocer los márgenes de valoración normal que se asigna para determinado producto, como bien precisa Abdías Sotomayor (2003):

El importador puede o no, conocer que el precio ofertado por el exportador es un precio inferior a lo que vendría a ser el valor normal. El importador no puede presumir la existencia del dumping, ya que se presume la buena fe (aunque en algunos casos el importador pueda notar grandes diferencias entre distintos precios de varios exportadores). (pág. 37)

Una vez finalizada la investigación, la Comisión se encarga de aplicar los derechos antidumping sobre determinada partida arancelaria; por su parte, SUNAT se encarga de realizar el cobro de dichas medidas; y el importador deberá realizar el pago de éstas para poder nacionalizar la mercancía y disponer de ellas dentro del territorio nacional.

- Exportador: Es la persona natural o jurídica que ejecuta una conducta desleal, en el marco del comercio internacional, mediante la exportación de un producto con un precio de exportación dumping.

Éste además puede ser productor de la mercancía en cuestión y puede comercializarlos dentro del mercado del país de origen. El hecho de que el exportador detente además la condición de productor podría hacer más plausible 
la creación de las condiciones desleales, así por ejemplo, podría tomar ventaja del vínculo comercial que existe con los consumidores de su mercado doméstico para asignarles un costo mayor por un producto, mientras que ejecuta exportaciones de esa misma mercancía, pero con precios dumping, favoreciendo, mediante distorsiones comerciales, al consumidor final del país de destino.

Dentro del procedimiento antidumping, el exportador podrá participar, entregando la información que permita determinar si se ejecuta una conducta desleal, asimismo, éste podrá reforzar su defensa mediante la participación de una institución del gobierno del país de origen como parte dentro de la investigación.

\subsubsection{INICIO DEL PROCEDIMIENTO:}

Una investigación antidumping puede comenzar por iniciativa de la Comisión, mediante un procedimiento de oficio, o a través de una solicitud de parte. Por un lado, será de oficio cuando la Comisión cuente con pruebas suficientes de los elementos dumping y cuando existan circunstancias especiales que así lo requieran, ello hace referencia a supuestos como (i) cuando la industria del país importador no está organizada, (ii) cuando ésta se encuentra atomizada, es decir, disgregada en pequeñas empresas, (iii) o cuando medie interés nacional.

Por otro lado, una solicitud de parte deberá ser presentada por, por lo menos, el $25 \%$ de empresas que represente la producción nacional del producto similar materia de la investigación. Asimismo, se deberán incluir pruebas suficientes de la práctica dumping, del daño o amenaza de daño y del nexo causal así como cualquier otra información relevante. La solicitud deberá ser acompañada además por un cuestionario que será suministrado por la Comisión y llenado por el solicitante.

Una vez que la Comisión recepcione la solicitud escrita y el cuestionario realizado por el peticionario, ésta podrá proceder de alguna de las siguientes formas: 
- La Comisión puede resolver el inicio de la investigación dentro de los 30 días siguientes desde la fecha de presentación de la solicitud.

- En caso existan observaciones respecto a los requerimientos que forman parte de la solicitud, la Comisión otorgará 15 días para que el peticionario cumpla con subsanar. Una vez corregidas las observaciones, la Comisión contará con un plazo de 15 días para (i) determinar la continuación del procedimiento de investigación antidumping o (ii) declarar la inadmisibilidad de la solicitud por no haberse cumplido con subsanar de forma correcta las observaciones. Cualquiera sea la resolución de la Comisión, ésta se deberá sustentar en una Resolución.

- Dentro del plazo de 30 días la Comisión podrá denegar la solicitud por considerarla improcedente, del mismo modo, deberá emitir una Resolución fundamentando su resolución.

\subsubsection{REMISIÓN Y ABSOLUCIÓN DE CUESTIONARIOS:}

Una vez que la Comisión ha publicado la Resolución de Inicio del procedimiento administrativo en el Diario Oficial El Peruano, la Secretaría Técnica contará con un plazo de 10 días para remitir la solicitud acompañada de sus anexos y un cuestionario para ser llenado por la parte investigada.

El artículo 26 del Reglamento Antidumping señala que se deberá remitir los cuestionarios a las partes citadas en la denuncias, por tanto, se notificará dichos documentos a los importadores y al exportador o productor extranjero investigado por práctica de dumping; este último cuestionario contiene rubros en el que se solicitan datos generales, tales como información sobre la empresa extranjera investigada, el producto investigado, las condiciones de mercado en las que opera la empresa, la modalidad de producción o adquisición del producto investigado, los datos relacionados al precio de venta del producto investigado, las ventas en el mercado interno y externo e información adicional relacionada con la memoria anual de la empresa extranjera y su estado de resultados. 
Las partes notificadas deberán resolver los cuestionarios y presentar sus descargos dentro de los próximos 30 días desde la remisión de dichos documentos.

\subsubsection{PERIODO PROBATORIO:}

En la etapa probatoria se otorga un plazo de 06 meses para que todas las partes que participan en el procedimiento administrativo presenten sus pruebas y alegatos. Este periodo se contabilizará desde la publicación de la Resolución de Inicio de la investigación antidumping en el Diario Oficial El Peruano. Este plazo podrá ser prorrogado por 03 meses adicionales según lo complejidad del caso y de acuerdo al criterio de la Comisión.

Es importante resaltar que independientemente de que existan plazos dentro del periodo probatorio, la Comisión se encuentra facultada para solicitar información adicional a cualquiera de las partes y en cualquier etapa del procedimiento, ello con el fin de que la decisión final se encuentre sustentada en la mejor información recibida.

\subsubsection{HECHOS ESENCIALES Y FIN DEL PROCEDIMIENTO:}

La Comisión deberá emitir el Documento de Hechos Esenciales en los 30 días siguientes de haberse concluido la etapa probatoria. Este documento contendrá toda la información que se expuso durante la investigación y servirá de base para decidir si se aplica o no medidas antidumping definitivas.

Dentro de los 05 días hábiles siguientes, el documento de hechos esenciales deberá ser facilitado a todas las partes que intervinieron en el procedimiento administrativo para que éstos puedan defender sus intereses o hacer comentarios a dicho documento, para lo cual contarás con 10 días. Una prerrogativa que se les otorga a las partes en esta instancia es la de solicitar una audiencia pública en la que puedan exponer sus alegatos. 
Una vez transcurrido este periodo, la Comisión contará con 30 días para emitir una Resolución que ponga fin al procedimiento mediante la imposición o no medidas antidumping. La Comisión podrá abstenerse de aplicar derechos antidumping en los siguientes supuestos:

- Cuando el exportador del país investigado garantice la eliminación del daño a la industria nacional mediante un compromiso de precios, la Comisión podrá decidir poner fin a la investigación sin la imposición de medidas previsionales o definitivas, siempre que la contraparte haya aceptado dicho compromiso y que la Comisión tenga la convicción de que se garantiza la protección a la industria nacional. La Comisión está obligada a hacer un constante seguimiento al compromiso de precios para constatar su cumplimiento, en cuyo caso tendrá que recibir información de forma periódica del exportador.

- Cuando no existan pruebas suficientes que sustenten la existencia de daño, amenaza de daño o la relación causal, la Comisión deberá declarar infundada la solicitud y poner fin al procedimiento antidumping sin la aplicación de medidas.

- Cuando el margen de dumping no supera el minimis, es decir, cuando la diferencia entre el valor normal y el precio de exportación no sobrepase el $2 \%$.

- Cuando el volumen de las importaciones materia de la investigación sea insignificante. Según el numeral i del artículo 44 del Reglamento Antidumping, las importaciones serán consideradas como insignificantes por la Comisión cuando representen menos del 3\% de las importaciones del producto similar en el Perú.

\subsubsection{RECURSOS ADMINISTRATIVOS:}

En el Reglamento Antidumping se ha dispuesto el acceso a dos recursos administrativos que permiten la revisión de las decisiones tomadas por la Comisión de Dumping, Subsidios y Eliminación de Barreras no Arancelarias, la cual se constituye como la primera instancia administrativa. La parte interesada en la interposición de una 
medida de impugnación contará con un plazo de 15 días hábiles, computados desde la fecha de publicación de la Resolución Final en el Diario Oficial El Peruano.

Por un lado, el recurso de reconsideración será interpuesto ante la misma instancia que emitió la Resolución materia de revisión, en este caso, la Comisión, quien contará con un plazo de 30 días para resolver la impugnación. Por otro lado, el recurso de apelación será presentado ante la Comisión, que deberá elevar el expediente en los siguientes 10 días hacía la Sala Especializada en Defensa de la Competencia del INDECOPI (en adelante el Tribunal), el cual deberá resolver la apelación dentro de los 06 meses siguientes, computados desde la fecha de interposición de la impugnación.

Se entiende entonces, que el procedimiento antidumping garantiza la doble instancia administrativa, siendo la Comisión quien decide en primera instancia y el Tribunal quien resuelve en última instancia. Según señala el artículo 66 del Reglamento Antidumping, con la Resolución del Tribunal queda agotada la vía administrativa, ello en concordancia con el inciso b del artículo 218.2 de la Ley $27444^{33}$.

De tal suerte, cuando un funcionario inferior en la escala administrativa dicta un acto agraviante para los intereses de algún administrado, le corresponde recurrir mediante apelación ante el superior jerárquico, con el objetivo de obtener - es esa segunda instancia- una decisión favorable a su pretensión. Si el superior ratifica la decisión del subalterno, es contra esta decisión que corresponde intentar la acción contencioso - administrativo.

(Morón Urbina, 2015, pág. 696)

\subsubsection{REVISIÓN JUDICIAL:}

El artículo 13 del Acuerdo Antidumping exige la existencia y acceso a las vías judiciales que permitan a los interesados solicitar la revisión de las Resoluciones

\footnotetext{
33 Artículo 218.2 de la Ley del Procedimiento Administrativo General: Son actos que agotan la vía administrativa:

b) El acto expedido o el silencio administrativo producido con motivo de la interposición de un recurso de apelación en aquellos casos en que se impugne el acto de una autoridad u órgano sometido a subordinación jerárquica.
} 
emitida en vía administrativa: Cada Miembro en cuya legislación nacional existan disposiciones sobre medidas antidumping mantendrá tribunales o procedimientos judiciales, arbitrales o administrativos destinados, entre otros fines, a la pronta revisión de las medidas administrativas vinculadas a las determinaciones definitivas y a los exámenes de las determinaciones en el sentido del artículo 11. Dichos tribunales o procedimientos serán independientes de las autoridades encargadas de la determinación o examen de que se trate.

Con arreglo a lo antes señalado, el artículo 148 de la Constitución Política del Perú reconoce a los administrados la prerrogativa de impugnar las resoluciones administrativas mediante el ejercicio de su derecho de acción en un proceso contencioso-administrativo. Por su parte el artículo 218.1 de la Ley 27444 ratifica lo establecido por la Carta Magna con respecto al derecho de impugnación en el Poder Judicial. Ello nos remite además a la Ley 27584, Ley que regula el proceso contencioso administrativo, documento que será analizado a continuación.

Según el artículo 17 de la Ley 27584 el administrado deberá interponer la demanda ante el Poder Judicial dentro de los 03 meses siguientes desde que se toma conocimiento o se notifica el acto materia de impugnación. Este plazo deberá ser tomado en cuenta por la parte

Con el propósito de que la demanda sea declarada procedente y de acuerdo a lo que se ha venido señalando, el interesado deberá acreditar que se han agotado todas las vías administrativas; en el procedimiento administrativo de investigación antidumping, ello se acredita con la Resolución Final publicada por el Tribunal de INDECOPI, se entiende así que esta resolución se constituye como un elemento esencial de admisibilidad del proceso contencioso administrativo.

El sujeto con legitimación para obrar activa tendrá 03 meses para poder interponer una demanda contencioso administrativo en contra del agente administrativo que emitió en última instancia la Resolución Final; el plazo antes señalado se computará desde que el administrado toma conocimiento o se le notifica respecto de la declaración de la administración. 
El demandante impugnará alguna de las actuaciones administrativas listadas en el artículo 4 de la Ley $27584^{34}$ y ventilará la causa ante el Juzgado Especializado en lo Contencioso Administrativo. Mientras que la Sala Especializada en lo Contencioso Administrativo de la Corte Superior respectiva, será a la entidad a la que se recurrirá en caso se apele la decisión emitida en primera instancia. Finalmente, se agota la vía judicial en sede casatoria, en cuyo caso se deberá acudir a la Sala de Derecho Constitucional y Social de la Corte Suprema.

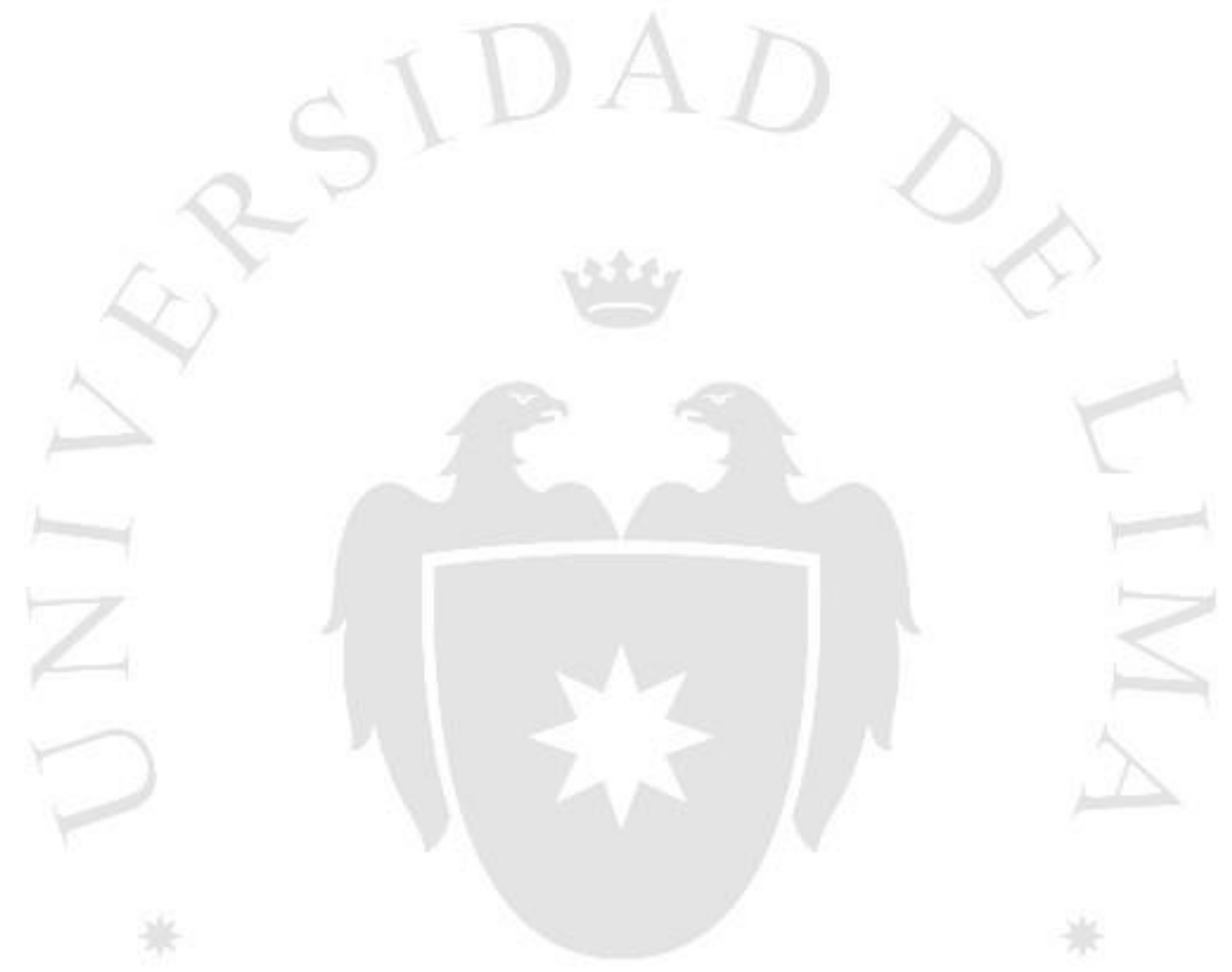

$34 \quad$ Artículo 4 de la Ley 27584.- Actuaciones impugnables

Conforme a las previsiones de la presente Ley y cumpliendo los requisitos expresamente aplicables a cada caso, procede la demanda contra toda actuación realizada en ejercicio de potestades administrativas. Son impugnables en este proceso las siguientes actuaciones administrativas:

1. Los actos administrativos y cualquier otra declaración administrativa.

2. El silencio administrativo, la inercia y cualquier otra omisión de la administración pública.

3. La actuación material que no se sustenta en acto administrativo.

4. La actuación material de ejecución de actos administrativos que transgrede principios o normas del ordenamiento jurídico.

5. Las actuaciones u omisiones de la administración pública respecto de la validez, eficacia, ejecución o interpretación de los contratos de la administración pública, con excepción de los casos en que es obligatorio o se decida, conforme a ley, someter a conciliación o arbitraje la controversia.

6. Las actuaciones administrativas sobre el personal dependiente al servicio de la administración pública. 


\section{Capítulo IV}

\section{PRÁCTICAS ELUSIVAS FRENTE AL DERECHO ANTIDUMPING}

\subsection{INTRODUCCIÓN}

Desde la emisión de la primera normativa antidumping en Canadá, pasando por la difusión del GATT y el Acuerdo Antidumping y finalizando con la obligatoria adopción, a nivel interno, de disposiciones que ratifiquen los acuerdos internacionales, la aplicación de derechos antidumping a productos extranjeros se incrementaron considerablemente. Así, por ejemplo, según los resultados que arrojan las estadísticas publicadas, respecto a la aplicación de medidas no arancelarias, Estados Unidos y la Unión Europea serían los países que más aplicaron derechos antidumping durante el periodo que comprenden los años de 1994 a 2015. Como se observa en el cuadro que se presenta a continuación, por un lado, Estados Unidos, hasta la fecha, mantiene 326 medidas antidumping vigentes, mientras que 491 procedimientos por posible existencia de prácticas dumping se encuentran aún en curso, asimismo se muestra que 344 medidas han sido derogadas por expiración de medidas antidumping (sunset review) o por cambio de circunstancias que ameriten la eliminación de los derechos antidumping. Por otro lado, en el caso de la Unión Europea se exponen 317 medidas vigentes, 391 medidas en preparación y 334 medidas derogadas: 
Tabla 4.1.

Medidas Antidumping derogadas, en preparación y vigentes aplicadas en Estados Unidos y la Unión Europea desde 1994 hasta el 2015

\begin{tabular}{|l|c|c|}
\hline \multicolumn{1}{|c|}{ País que impone } & Fase & Medidas \\
\hline Estados Unidos & Derogado & 344 \\
\cline { 2 - 3 } & En preparación & 491 \\
\cline { 2 - 3 } & Vigente & 326 \\
\hline Unión Europea & Derogado & 334 \\
\cline { 2 - 3 } & En preparación & 391 \\
\cline { 2 - 3 } & Vigente & 317 \\
\hline
\end{tabular}

Fuente: OMC

Elaboración: por mí

En: https://i-tip.wto.org/goods/Forms/TableView.aspx

Por su parte, Canadá y Nueva Zelanda son países que muestran cifras más moderadas; así, las medidas antidumping vigentes hasta la fecha son 141 y 22 respectivamente.

Tabla 4.2.

Medidas Antidumping derogadas, en preparación y vigentes aplicadas en Estados Unidos y la Unión Europea desde 1994 hasta el 2015

\begin{tabular}{|l|c|c|}
\hline \multicolumn{1}{|c|}{ País que impone } & Fase & Medidas \\
\hline Canadá & Derogado & 155 \\
\cline { 2 - 3 } & En preparación & 175 \\
\cline { 2 - 3 } & Vigente & 141 \\
\hline Nueva Zelanda & Derogado & 31 \\
\cline { 2 - 3 } & En preparación & 33 \\
\cline { 2 - 3 } & Vigente & 22 \\
\hline
\end{tabular}

Fuente: OMC

Elaboración: por mí

En: https://i-tip.wto.org/goods/Forms/TableView.aspx 
Naturalmente, la variación de cifras que proyecta cada país responde a diferentes factores relacionados con sus flujos de comercio exterior, sin embargo, el objetivo de exponer dichos cuadros se centra en resaltar la gran incidencia que han tenido los derechos antidumping, como medida no arancelaria, en el escenario internacional.

Como lo analizamos capítulos atrás, el interés común plasmado en las Rondas Internacionales, desarrolladas bajo el marco de la OMC, tenía como principal foco la participación de los Países Miembros en la reducción de los aranceles; no obstante, paralelamente se configuró un sistema reglamentario que permitió, bajo ciertos límites, la aplicación legitima de medidas no arancelarias, como lo son los derechos antidumping. En base a esta prerrogativa, el índice de investigaciones por prácticas dumping se incrementó en varios países, pero principalmente en la Unión Europea y Estados Unidos; ello se debió al incremento de las transacciones comerciales realizadas entre los actores internacionales, natural consecuencia de las facilidades operativas y concesiones arancelarias; además de la formalización de un respaldo legal y procesal que permite la aplicación de medidas no arancelarias. Por su parte, los Países Miembros que se veían especial y recurrentemente afectados por procedimientos antidumping eran las naciones asiáticas, llámese China, Japón, Corea del Sur, entre otros, quienes acusaban incesantemente y tildaban de proteccionistas a los Estados que ejercían válidamente los mecanismos legítimamente reconocidos e íntegramente aceptados bajo el respaldo de la OMC.

Al respecto, creo fervientemente que la correcta utilización de los derechos antidumping son erróneamente etiquetados como medidas proteccionistas; para explicar mi punto de vista, pasaré a exponer mis razones.

En primer lugar, debemos recordar que el principal objetivo que impulsó la reglamentación de estas medidas se circunscribe en la eliminación de las distorsiones que perjudiquen el comercio internacional, mas no un afán de excesivo proteccionismo basados en la utilización de barreras paraarancelarias. 
En segundo lugar, los acuerdos adscritos a las medidas antidumping han sido reconocidos, ratificados e introducidos en las legislaciones internas de los países miembros; todo ello bajo la supervisión y control fiscalizador de un organismo internacional. China desde 2001, Japón ${ }^{35}$ desde 1995, y Corea del Sur $^{36}$ desde 1995 se han incorporado como países miembros de la OMC, sujetándose voluntariamente a su normativa y sistema; por tanto, mal harían aquellas naciones en cuestionar los derechos antidumping que previamente han ratificado.

En tercer lugar, la base procedimental establecida para investigar prácticas desleales en el marco internacional ha sido muy escrupulosa en detallar los criterios, las condiciones y los requisitos necesarios que permitan la aplicación de medidas. Es importante reconocer que el accionar de la autoridad administrativa que conocerá de los casos que exponen posibles prácticas dumping se encuentra delimitado por lo establecido en la normativa internacional y nacional porque ello va a permitir suprimir posibles conductas irregulares, arbitrarias o proteccionistas. Si analizamos lo antes señalado desde otro ángulo, se puede además revelar el carácter predecible de estos procedimientos y, especialmente, de las resoluciones que ponen fin a las investigaciones, pues el agente investigado puede acceder fácilmente a la jurisprudencia que expone y resuelve respecto a casuística antidumping. Asimismo, los exportadores y productores del país investigado cuentan con mecanismos de defensa que garantizan el debido proceso; por ejemplo, se reconoce el principio de la doble instancia, es decir, la decisión que se tome en primera instancia, respecto a la aplicación o no de medidas no arancelarias, podrá ser revisada por una entidad administrativa superior y, en su caso, podrá accederse al aparato judicial, el cual podrá revocar o confirmar la resolución adoptada por la administración. En el caso peruano, la entidad de primera instancia se adscribe a la Comisión de Dumping, Subsidios y Eliminación de Barreras no Arancelarias; mientras que la Sala Especializada de Defensa de la Competencia del INDECOPI conocerá el caso en apelación y en vía judicial, a través de un proceso Contencioso Administrativo, resolverá el Juez Especializado en lo Contencioso Administrativo. Finalmente, en caso de disconformidad respecto a la decisión

$35 \quad 10$ de setiembre de 1955 , fecha de adhesión al GATT.

$36 \quad 14$ de abril de 1967 , fecha de adhesión al GATT. 
tomada por la autoridad de la nación importadora, el país del agente investigado podrá ventilar el caso ante la OMC, mediante un proceso de solución de diferencias.

Finalmente, resultaría inmerecido el no reconocer los favorables resultados económicos y de bienestar social generados en razón de la apertura comercial y el libre comercio, sin embargo, pienso que, a pesar de ello, no debe dejarse de considerar el rol fiscalizador y de control que deberá ejercer cada Estado frente a los agentes internacionales de comercio. En este punto, hacemos referencia a la obligación que tienen las autoridades competentes de velar, desde el marco de su jurisdicción, por el correcto ejercicio de las actividades mercantiles internacionales; se trata pues de una función que deberá ejercer en razón de su soberanía. Nótese que se habla de un intervencionismo estatal proporcionado y suficiente para eliminar distorsiones en el comercio internacional y no de una participación que entorpezca el libre flujo comercial o que se limite a minar nuestro mercado de medidas antidumping exponiendo un resguardo desmedido a determinada rama de producción nacional. Nuestra postura se vincula pues a la teoría regulatoria, la cual es explicada por Aníbal Sierralta (2014) de la siguiente manera:

John Maynard Keynes defendió una acción más activa y regulatoria por parte del Estado en la conducción del comercio, con el objeto de morigerar las fluctuaciones económicas y complementar la iniciativa privada respecto de la inversión y evitar de esa manera la paralización en el largo plazo, debido a la tendencia declinante de la eficiencia marginal del capital. (pág. 49)

En la medida en que el símil sea válido, podríamos decir que en el tablero coexisten diversos países, los cuales participan y mueven sus fichas de acuerdo a sus propios propósitos y ambiciones. Para armonizar todos estos intereses contrapuestos se plantearán ciertas "reglas de juego" que son preestablecidas y aceptadas consensualmente por los agentes comerciales quienes deberán ajustar su participación en el mercado de acuerdo a lo ya fijado. En este escenario, se congregan autoridades administrativas que representan a cada nación y éstas tendrán la consigna de mantener una actitud fiscalizadora y de control respecto a las intervenciones de cada participante. Se sabe anticipadamente 
que, en caso de que alguno de estos países incurra en los supuestos que configuren una práctica desleal conforme a los acuerdos reguladores, la autoridad correspondiente podrá válidamente investigar $\mathrm{y}$, en su caso, aplicar una multa que ayude a equilibrar las condiciones del juego, por tanto, mal haría el país acusado en cuestionar y calificar como proteccionista la participación del país examinador, teniendo en cuenta que se cumplen con las garantías y principios que inspiran la armonía de este juego. De este modo, puedo decir que no se trata de acusar a otros países de incrementar desmedidamente las investigaciones antidumping, sino que más bien se deberían dirigir los esfuerzos en ajustar su accionar comercial a las leyes y reglamentos existentes, además de brindar un marco normativo interno idóneo que permita concientizar a los exportadores y productores respecto a la importancia de una leal competencia en el mercado interno como externo. Al respecto, me gustaría citar a Abdías Sotomayor (2003) quien, analizando las circunstancias desde otra óptica, exhibe la problemática de tener una legislación interna que aborda de forma incipiente las prácticas desleales en el comercio o la ausencia total de normativa al respecto y la repercusión que genera ello en la participación en el mercado externo:

En la mayoría de países acusados de dumping, hay una ausencia de normas antitrust, estas son ineficientes (ya que solo controlan y prohíben algunos tipos de prácticas anticompetitivas), o no cuentan con entes nacionales (especializados y autónomos). Incluso, en algunos casos, es el propio Estado quien permite las prácticas de discriminación internacional de precios, manteniendo barreras de acceso al mercado doméstico de los exportadores, ya que no se prohíben los actos de abusos de posición de dominio de las empresas exportadoras que realizan el dumping. En Corea del Sur y Japón existen normas antitrust, pero ellas tienen defectos legislativos o son aplicadas de manera incorrecta (por no decir que las autoridades estatales permiten o alientan dichas prácticas). Otros países como Bangladesh, Malasia e Indonesia carecen de normas antimonopolio, lo que significa que existen las condiciones para que los empresarios exportadores realicen el dumping. (pág. 110) 
Lo cierto es que la realidad comercial muestra otro escenario y resulta que el incremento de las investigaciones antidumping impulsó una actitud de más revanchista y persistentemente desleal por parte de actores comerciales de los países comúnmente investigados por prácticas dumping. Esta reprochable actitud se proyecta a través de diversos supuestos elusivos que pueden configurarse fácilmente, pues estos países escudan su accionar en base a factores que acompañan la existente coyuntura comercial, tales como la interconexión de países, la globalización, la tecnología, el afán de cooperación internacional y la creciente tendencia de suscribir tratados bilaterales y multilaterales que otorgan beneficios comerciales.

Los agentes de los países asiáticos fastidiados por el incremento de los procedimientos administrativos y la potencial aplicación de derechos antidumping, decidieron incurrir en prácticas de elusión que no buscan otra cosa más que eliminar los efectos correctores adscritos a las medidas antidumping. Esta actitud manifiesta claramente una intención de perpetuar prácticas desleales en el comercio internacional, es decir, en vez de redireccionar su acción con arreglo a lo establecido por los convenios internacionales, estos países se manifiestan burlando el sistema operativo y normativo desarrollado para la común concordia.

Y es que por un afán de evitar el pago de derechos antidumping los actores comerciales, cuyos productos exportados están sujetos al pago antidumping, han ideado diversas formas de repeler los mecanismos aplicados en contra de los precios con margen dumping. La casuística internacional ha demostrado que el ingenio de elusión ha desencadenado diversos supuestos de hecho elusivos.

Sin embargo, a pesar de ser éste un tema de coyuntura en el marco internacional, la $\mathrm{OMC}$ no ha emitido pronunciamiento normativo al respecto. Ahora, si bien es cierto que se han generado momentos de discusión en torno al tema, más aún, se ha delegado a una Comisión la elaboración de un cuerpo normativo que desarrolle disposición antielusión, puede decirse que en los últimos años no ha habido mayor avance y ello se debe principalmente a lo complejo que es establecer un consenso sobre el tema entre todos los 
países miembros. Pienso, sin embargo, que del mismo modo como hubo un pronunciamiento sobre la discriminación internacional de precios, concluyéndose con la aplicación de derechos antidumping, se debe responder a la evolución de la conducta humana que se manifiesta ahora mediante la innovación elusiva. Resulta pues obvio que la OMC, como importante organización internacional, llame al consenso y decida normar el tema.

Este vacío legal en el marco internacional generó una rápida respuesta en la normativa interna de diversos países como la Unión Europea, Estados Unidos, Canadá, Nueva Zelanda, México, entre otros, quienes extienden la aplicación de los derechos antidumping a las importaciones elusivas. Nuestro país, a través de la Comisión de Dumping, Subsidios y Eliminación de Barreras no Arancelarias ha enfrentado casuística que manifiesta conductas elusivas, sin embargo, la autoridad administrativa no se encuentra en capacidad de extender los derechos antidumping ante estos supuestos, pues no existe un dispositivo legal que así se los permita. Si bien hay un artículo en el Reglamento Antidumping que hace referencia a solo un tipo de elusión, ésta es muy limitada y no permitiría hacer frente a las diversificadas conductas elusivas.

Este acápite introductorio esboza de manera general la problemática que inspira el presente trabajo y que hace referencia al importante incremento de prácticas elusivas que solo busca perpetuar las distorsiones en el comercio internacional y burlar los efectos correctores determinados por los derechos antidumping. En los capítulos siguientes, se plantearán ciertas propuestas que hagan frente al vacío legal existente en materia de prácticas elusivas en el marco del Derecho Antidumping. Para ello tendremos en cuenta la legislación comparada, la opinión de diversos juristas, la posición de organizaciones y empresas relacionadas al comercio exterior, así como la propuesta legislativa presentada por la Comisión el pasado 2011. 


\subsection{DEFINICIÓN DE PRÁCTICAS DE ELUSIÓN Y SUS MODALIDADES}

Para abordar de mejor manera el tema que aquí nos trae, es menester esbozar las definiciones que se han ido desarrollando, a nivel doctrinal, en torno a la elusión de derechos antidumping. En primera instancia, y para tener una noción general del término, el Diccionario Jurídico precisa que: "Se trata de apelar a formas o estructuras diferentes de las convencionales con tal de dar a un hecho imponible una investidura diferente sin alterar por ello su real naturaleza o sustancia" (Casado, 2009, pág. 333).

Por otro lado, en su portal web, la OMC (2003) explica que la elusión, bajo el contex to comercial:

Consiste en evadir el cumplimiento de compromisos en la OMC, tales como los compromisos de limitación de las subvenciones a la exportación de productos agropecuarios. Por ejemplo: evitar la imposición de contingentes y otras restricciones modificando el país de origen de un producto; medidas adoptadas por los exportadores para evadir la imposición de derechos antidumping o compensatorios.

(Organización Mundial de Comercio , 2003)

En el ensayo "Antidumping circumvention in the EU and the US: is there a future for multilateral provision under the WTO?" Lucia Ostoni (2005) precisa que:

Las estrategias de elusión se basan en ocultar el origen de los productos dumping, confundiendo a la autoridad del país de importación, así como a los participantes del comercio y consumidores. Estas estrategias consisten en alterar el producto sujeto a derechos antidumping o mediante la transferencia en todo o en parte, la manufactura y/o el ensamblaje de aquel producto desde el país de origen (en el cual se aplicaron las medidas antidumping) a un país diferente. (pág. 409) 
Mientras que Henrik Olsson (1999) además de conceptualizar la elusión, puntualiza algunas fórmulas en las que ésta se manifiesta:

La elusión simplemente significa evitar o evadir, por lo que, en el caso antidumping implica evitar el pago de los derechos antidumping los que de otro modo se pagarían. Hay numerosas formas en las que la elusión puede ocurrir, aquellos son: modificaciones menores, operaciones de ensamblaje, transbordo y declaraciones de mercancías incorrectas. (pág. 13)

Por su parte, El profesor Chávez Bardales (2009) va más allá y, al respecto, puntualiza que las conductas elusivas serían consideradas legalmente atípicas, en cuanto se configuran supuestos no contemplados como elusivos en la norma:

La elusión se concentraría en realizar importaciones de mercaderías que, al no estar comprendidas estrictamente dentro de los alcances de aquellas consideradas bajo la autoridad nacional del país de importación como obligadas al pago de derechos antidumping, no estén bajo el deber de cumplir con su pago respectivo. Sin embargo, tendría que tratarse de un procedimiento que utilice artificios tales que finalmente se logre el resultado económico que la ley pretende gobernar pero que, justamente por ser atípico, no le alcanza legalmente; en nuestro caso, que estén vendiéndose en el país de importación productos similares a aquellos que debían haber pagado derechos antidumping y no lo hayan hecho. (pág. 123)

En nuestro caso, el Reglamento Antidumping realiza una sucinta aproximación sobre el tema, muestra de ello, es el somero desarrollo realizado en el único artículo que aborda la problemática elusiva. Por esta razón, una de las propuestas que esta tesis plantea consiste en la inclusión de una disposición que comprenda una definición clara de lo que es elusión de derechos antidumping y lo que se considera una práctica de comercio regular y justificable económicamente. La ejecución de la propuesta planteada va a permitir que los agentes comerciales conozcan de antemano qué será considerado por la autoridad como una práctica elusiva sancionable y una actividad comercialmente aceptable. 
Otra de las falencias que expone el Reglamento Antidumping consiste en el limitado reconocimiento de fórmulas elusivas. El artículo desarrolla solo el supuesto consistente en la exportación, al país de destino o un tercer país, de partes, piezas y componentes, sin embargo, este precepto no alcanza a cubrir otro tipo de conductas que se han ido desarrollado y que tienen como principal objeto eludir el pago de las medidas antidumping.

$\mathrm{Y}$ es que en un afán por evitar el pago de derechos antidumping, los agentes comerciales, cuyos productos están sujetos al pago de medidas paraarancelarias, han ideado diversas formas de repeler los mecanismos aplicados en contra de los precios con margen dumping. La casuística internacional ha demostrado que el ingenio comercial ha desencadenado diversos supuestos elusivos; los países asiáticos son los que principalmente han urdido las siguientes fórmulas elusivas:

3.2.1. En primer lugar, podríamos describir la elusión que se desarrolla mediante la participación de un tercer país. El país de origen envía partes, piezas o componentes del producto al que se le aplicó las medidas antidumping a un tercer país que fungirá de país exportador; en este último lugar se realizan unas actividades mínimas de producción y acabado para, posteriormente, exportar el producto final al país que aplicó las medidas. Para graficar la explicación antes realizada, podemos describir el siguiente ejemplo: Imaginemos que el país $\mathrm{C}$ ha determinado la aplicación de derechos antidumping a la importación de radio grabadoras originarias del país B; con el fin de evitar el pago de aquellas medidas, los productores del país B deciden enviar el reproductor de $\mathrm{CD}$, bandas de radio, circuitos integrados de diodos, transistores, láser, etc. Es decir, exportan las partes y pieza del producto final hacia el país A el cual se encarga de completar y exportar el producto final al país C. La autoridad de este último país no podría aplicar los derechos antidumping, en tanto, la medida se adscribe a las importaciones originarias del país B y no C. Como podrá notarse, la participación comercial se concentra en tres países: país de origen, país de exportación y país 
de destino. Este supuesto es conocido, en el sistema del common law, como Third-country Circumvention.

4.2.2. Otra de las fórmulas ejecutadas frecuentemente consiste en la exportación, por parte del país al que se le impuso el pago de derechos antidumping, de partes, piezas o componentes al país afectado por las prácticas dumping; una vez que aquellos se encuentren en el país de importación, serán ensamblados y completados. Este supuesto es parecido al descrito en los párrafos previos, sin embargo, en este caso el lugar de origen y el de exportación recae sobre el mismo país, que es desde donde se exportan las partes directamente al país de destino. Para redondear la explicación, concibamos, por ejemplo, que las autoridades del país $\mathrm{C}$ concluyen un proceso de investigación antidumping con la imposición de medidas de defensa comercial sobre los calzados de cuero, originarios del país B. Tras dicho dictamen, los productores de este último país decidieron sustituir las exportaciones del producto final por las piezas del calzado para poder completarlos dentro del país C. Esta fórmula elusiva es popularmente conocida como Upstream Circumvention.

La ejecución de este supuesto elusivo implica la apertura de una planta de ensamblaje en el país de importación, lo que nos obliga a abordar otro tema: la Inversión Extranjera Directa ${ }^{37}$. No cabe duda que las políticas económicas de todo país incorporan el factor de la inversión directa y por ser un elemento económico preponderante se la incluye también en sus Balanzas de Pagos ${ }^{38}$, pero ¿cómo la autoridad del país importador deberá tratar las conductas elusivas bajo

37 Según Yanning Yu (2008), cuando se habla de Inversión Extranjera Directa se hace referencia a "la transferencia de fondos, capital, tecnología, marketing y capacidad de gestión y recursos desde un país hacia otro, con el propósito de utilizarlos en la dirección de una empresa en este último país, a cambio de la participación directa de las ganancias de esa empresa. La Inversión Extranjera Directa promueve el desarrollo de la economía y crea oportunidades. Los países, sean estos desarrollados o no, buscan atraer y estimular el crecimiento de su economía mediante la Inversión Extranjera Directa” (pág. 187)

38 Según el Banco Central de Reservas del Perú (s.f.): "Dentro de la balanza de pagos, registra el intercambio de mercancías de un país con el resto del mundo. Su saldo es la diferencia entre los ingresos por exportaciones y los gastos por importaciones". 
la luz de la inversión directa? Yanning Yu (2008) nos plantea la siguiente respuesta:

La relación entre las medidas antielusivas y las inversiones directas nos dejan las siguientes conclusiones (i) Desde la perspectiva del país importador, el único propósito de establecer una planta de ensamblaje es para eludir la legislación antidumping. Aquella práctica de inversión puede ser vista como una "omisión arancelaria" mediante una inversión. (ii) La "omisión arancelaria" mediante inversión crea pocos trabajos para los trabajadores del país importador y provee poco valor agregado a los productos ensamblados. Por tanto, "la omisión arancelaria" afecta el bienestar social del país importador, aunque no afecta el sistema legal (como el sistema de impuestos). (iii) Los efectos negativos de la "omisión arancelaria" mediante inversión exceden los positivos, por tanto, las inversiones directas solo serán permitidas si éstas ofrecen más efectos positivos. Por lo que una práctica de inversión será permitida si ésta puede crear más trabajos o mayor valor agregado y, por tanto, más beneficios para el país de importación. (pág. 191)

Muchos países desarrollan estrategias económicas para incentivar y atraer la inversión extranjera y aunque ello es deseable, los beneficios que la inversión ofrece se ven reducidos y limitados por la conducta elusiva.

4.2.3. Por otro lado, ésta práctica elusiva va más allá, pues no solamente se exportan las partes y componentes, sino que se traslada la planta de producción al país destino, el cual aplicó las medidas antidumping, o a un tercer país. En la medida en que el bien final es elaborado en país diferente al exportador originario, no se pagarán las medidas de defensa comercial.

Desde el enfoque de la inversión directa, esta fórmula elusiva puede ser más beneficiosa que el supuesto elusivo anterior, pues implica el traslado completo de la planta de producción y no solo de la planta de ensamblaje. Ello va a permitir la 
difusión de tecnología y valor agregado en el país de destino. Sin embargo, esta práctica será deseable en tanto sea considerada una inversión directa "quid pro quo", como bien lo ha calificado Yanning Yu (2008); esta categoría implica ejecutar las prácticas comerciales de inversión antes de la iniciación del procedimiento antidumping (como bien puntualiza la normativa norteamericana y europea) y, consecuentemente, antes de que las medida de defensa comercial hayan sido impuestas. (pág. 192)

Por ello, dependerá de las circunstancias que rodea a la práctica y del tiempo en la que ésta se ejecuta para determinar si se trata de una conducta elusiva objeto de sanción o una situación justificable de inversión directa que incluso puede favorecer a la economía doméstica.

4.2.4. Bajo este supuesto, la mercancía final, sujeta al pago de derechos antidumping, es modificada de tal manera que se diferencia del producto originario, desvirtuando así el pago de los derechos antidumping. La alteración del producto podría además implicar el cambio de la partida arancelaria adscrita al producto original. Ahora, imaginemos que la autoridad administrativa del país $\mathrm{C}$ dispone la aplicación de derechos antidumping a las importaciones de sacos de tres capas de papel para cemento originarias del país B, éste último busca evitar el pago de las medidas antidumping mediante la sustitución de la importación del producto original por la importación de sacos de dos capas de papel. Como puede notarse del ejemplo antes desarrollado, la modificación realizada es insignificante, pero suficiente como para diferenciarlo del producto original. A este supuesto elusivo también se le denomina Minor Alteration Circumvention o Side-stream Circumvention.

4.2.5. Parte de la doctrina califica como supuesto de elusión básicos al transbordo y a la declaración incorrecta de las mercancías. Sobre el transbordo, el artículo 95 de la Ley General de Aduanas del Perú expresa que: 
Es el régimen aduanero que permite la transferencia de mercancías, las que son descargadas del medio de transporte utilizado para el arribo al territorio aduanero y cargadas en el medio de transporte utilizado para la salida del territorio aduanero, bajo control aduanero y de acuerdo con los requisitos y condiciones establecidos en el Reglamento. El transbordo puede efectuarse bajo las siguientes modalidades: directamente de un medio de transporte a otro, con descarga a tierra y con ingreso a un depósito temporal.

Bajo este supuesto, el exportador o productor pretende transferir origen a un tercer país mediante la realización de un simple transbordo. Para ello, la mercancía es transportada desde el país de origen hacia un tercer país, sin embargo, el producto no sufre ninguna alteración, ni forma parte de un proceso de producción. Esta conducta ya ha sido regulada por el artículo 2.5 del Acuerdo Antidumping ${ }^{39}$ y artículo 5 del Reglamento Antidumping.

Por otro lado, el artículo 2 de la Ley General de Aduanas del Perú señala que la Declaración Aduanera de Mercancías (DAM) es:

El documento mediante el cual el declarante indica el régimen aduanero que deberá aplicarse a las mercancías y suministra los detalles que la Administración Aduanera requiere para su aplicación.

La DAM comprende la siguiente información sobre la mercancía: el valor, la marca comercial, el modelo, descripciones mínimas, el estado, la cantidad comercial, el origen, el país de adquisición o de embarque, entre otros datos. Es menester que la información ahí incluida sea fidedigna, pues ello puede acarrear consecuencias económicas relacionadas al pago de medidas arancelarias,

39

Artículo 2.5.- En caso de que los productos no se importen directamente del país de origen, sino que se exporten al Miembro importador desde un tercer país, el precio a que se vendan los productos desde el país de exportación al Miembro importador se comparará, normalmente, con el precio comparable en el país de exportación. Sin embargo, podrá hacerse la comparación con el precio del país de origen cuando, por ejemplo, los productos transiten simplemente por el país de exportación, o cuando esos productos no se produzcan o no exista un precio comparable para ellos en el país de exportación. 
paraarancelarias o tributos. Cuando se consignan datos erróneos, se emite una Declaración incorrecta que, dependiendo del grado de la falta, podrá ser un supuesto no sancionable o una infracción aduanera plausible de sanción con multa $^{40}$. Estas medidas se complementan con la labor de control del origen de las mercancías sujetas a medidas de defensa comercial adscritas a la autoridad aduanera, regulado mediante Decreto Supremo Nº05-2011-MINCETUR.

Como podrá notarse, se han dispuesto consecuencias jurídicas suficientes ante la emisión de falsas o incorrectas declaraciones de mercancías o la realización de un simple transbordo, sin embargo, si estas conductas sirven como medio para además incurrir en una conducta de elusión de los derechos antidumping, entonces, sería conveniente aplicar las medidas antielusivas que correspondan.

La casuística en el comercio internacional ha permitido identificar diversas fórmulas de elusión de derechos antidumping, sin embargo, es importante entender que estos supuestos no pueden ser abordados, por una normativa, de forma taxativa, pues las conductas comerciales se diversifican y, con el afán de evitar las medidas de defensa comercial, los productores o exportadores podrán concebir nuevas conductas elusivas.

La respuesta normativa que se ha desarrollado a nivel internacional para enfrentar la problemática que implican las conductas elusivas consiste en extender la aplicación de los derechos antidumping, que fueron aplicados en la investigación antidumping realizadas originalmente por la autoridad competente, a los productos similares usados para eludir, en decir, los ensamblados, acabados o terminados y las mercancías ligeramente modificadas.

La regulación antielusiva, que se propone, debe ser lo más clara y detallada posible. La forma más óptima de abordar normativamente esta problemática es mediante la inclusión de una definición de elusión que establezca el punto de quiebre entre los que es aceptable y lo que no; una cláusula general que cubra la regulación de supuestos no establecidos expresamente y el listado de fórmulas elusivas que grafique las disposiciones

$40 \quad$ Al respecto, pueden revisarse el artículo 190 y siguientes de la Ley General de Aduanas. 
previas. Además, cada supuesto deberá comprender diversos criterios que especifiquen los elementos de juicios que deberán ser considerados por las autoridades para poder extender los derechos antidumping a los productos similares materia de la conducta elusiva. Asimismo, se deberán evitar las ambigüedades en la terminología usada, ello generará mayor certeza en los agentes comerciales. Finalmente, se podrá ejecutar un procedimiento más expedito que se anticipe a la configuración de otras conductas elusivas durante la investigación. Sin embargo, estas recomendaciones serán abordadas con mayor detalle en los capítulos siguientes.

\subsection{PRIMERAS APROXIMACIONES NORMATIVAS}

Las primeras intenciones normativas dirigidas a repeler prácticas elusivas provienen principalmente de dos fuentes. Por un lado, de los esfuerzos normativos unilaterales de países como la Unión Europea, el cual emitió la primera norma antielusión, en 1987, con el propósito de combatir las conductas elusivas de exportadores y productores japoneses. Por otro lado, de las negociaciones realizadas, desde 1990, en las Rondas de Negociación realizadas por los países miembros de la OMC. La respuesta normativa de la Unión europea será materia de análisis en el siguiente capítulo, mientras que las intenciones normativas de la OMC serán estudiadas a continuación.

Durante la Ronda de Uruguay se realizaron muchas discusiones sobre la conveniencia o no de normar en contra de las prácticas elusivas, las posiciones de los países miembros se fraccionaron y era en extremo difícil llegar a una resolución que armonice las dicotómicas posiciones. Con arreglo a ello, se decidió encargar al Director General Adjunto, el Señor Charles Carlisle, la elaboración de un documento que comprenda determinadas propuestas normativas que aborden la problemática. La iniciativa, también conocida como The Carlisle Draft Text I, fue presentada el 06 de julio de 1990, sin embargo, ésta fue rechazada por los países miembros, pues se consideró que la propuesta replicaba muchas disposiciones de la normativa antielusiva norteamericana, además de suprimirse la verificación de existencia de dumping y daño en el procedimiento de 
investigación de la conducta de elusión. Por todo ello, el texto fue calificado de incompatible con el GATT y se solicitó su revisión.

Los esfuerzos normativos se enfocaron en la elaboración de la segunda propuesta normativa, el cual concluyó el 14 de agosto de 1990 con la emisión de The Carlisle Draft Text II. Este proyecto normativo comprendía modificaciones, realizadas en función de las falencias contenidas en la propuesta previa, sin embargo, lo que más resaltó fue plantear la aplicación de un procedimiento antielusiva distinto para cada fórmula elusiva. No obstante, a pesar de las variaciones planteadas, la propuesta fue igualmente criticada y descartada por los países miembros del GATT.

El 30 de octubre de 1990 se presenta la tercera propuesta normativa con The New Zealand Draft Text el cual corrió con la misma suerte que los proyectos anteriores. Los países miembros señalaron que esta propuesta guardaba mucha relación con las disposiciones antielusivas de los sistemas norteamericano y europeo, por lo que, se preveía su incompatibilidad con el GATT. Nuevamente, la falta de consenso conllevó a la desaprobación del proyecto.

Durante la Ronda de Uruguay, la última intención normativa se plasmó en la propuesta realizada por el Director General del GATT, el Señor Arthur Dunkel, la cual se presentó como The Dunkel Draft Text. Se esperaba que el proyecto fuera incluido dentro del Acta Final en el que se incorporan los resultados de la Ronda de Uruguay de Negociaciones Comerciales Multilaterales, sin embargo, ello no ocurrió pues armonizar las distintas posturas fue una labor titánica y hasta imposible de lograr. Como bien señala Lucia Ostoni (2005):

El artículo 12 de The Dunkel Draft está dirigido a sintetizar la siguiente dualidad de necesidades concurrentes y opuestas: para limitar la acción de elusión de los derechos antidumping de los países importadores (como la UE y USA), y para protegerlo contra la aplicación penetrante de medidas antidumping a los países exportadores (como Japón). (pág. 413) 
Las críticas de uno y otro grupo se concentraron principalmente en discutir si el procedimiento debe incluir o no una investigación para determinar si existe dumping y daño. The Dunkel Draft se manifestó respecto a dos fórmulas elusivas: la exportación de partes, piezas y componentes al país de importación y la exportación de partes, piezas y componentes a un tercer país. En el primer supuesto se determinó que no era necesario fijar la existencia de daño, mientras que en la segunda fórmula se estableció la necesidad de precisar la existencia de ambos elementos (dumping y daño). Como bien sintetiza Yanning Yu (2008) la Unión Europea y los Estados Unidos acusaron que el hecho de incluir una investigación de dumping y daño, generaba la dilación del procedimiento, por lo que se estaba equiparando el procedimiento antidumping con el procedimiento antielusivo; con ello, según estos países, el Dunkel Draft había perdido su sentido original en relación con la elusión. Por otro lado, los países asiáticos exigen que la investigación de prácticas de elusión se ajusten a las disposiciones del Acuerdo Antidumping, por lo que, todas modalidades de elusión deben incluir el examen de dumping y daño. (pág. 139)

A pesar de existir intenciones, por parte de la OMC, de abordar el tema y enfrentar la problemática que implica el aumento en la ejecución de prácticas de elusión que tienen por objeto la eliminación de los efectos correctores adscritos a los derechos antidumping, no se han obtenido mayores resultados. Ninguna propuesta normativa realizada a nivel internacional ha podido equilibrar los intereses de los países miembros; es decir, no se ha alcanzado ningún acuerdo normativo, por lo que, las medidas antielusivas no se encuentra sistematizadas baja la dirección de la OMC. Ello puede resultar contraproducente porque es incuestionable que este problema está siendo enfrentado por cada país a través de la emisión de normativa antielusiva unilateral.

Es de consenso general la necesidad de que la OMC emita un pronunciamiento oficial para regular las prácticas elusivas en base a un acuerdo internacional que uniformice las medidas antielusivas y los criterios que deberán ser tomados en cuenta por la autoridad administrativa, pero mientras ello no ocurra los países seguirán regulando unilateralmente, pues éstos tendrán que preservar sus respectivos sistemas antidumping, ratificando los efectos correctores de las medidas de defensa comercial. 


\section{Capítulo V}

\section{LEGISLACIÓN COMPARADA}

\subsection{IMPORTANCIA DE SU ANÁLISIS}

En los últimos años se han evidenciado conductas elusivas dirigidas a rehuir el pago de derechos antidumping; ante ello, muchos países han resuelto combatir dichas prácticas mediante la aplicación de medidas antielusión, las cuales han sido incorporadas en su legislación interna. Sin embargo, existe en nuestro reglamento antidumping un vacío

legal, pues éste carece de disposiciones capaces de repeler las prácticas elusivas; esta condición limita la función reguladora y fiscalizadora de la autoridad administrativa peruana, pues ésta se encuentra imposibilitada de resolver en contra de las prácticas de elusión.

Si consideramos que el objetivo de las normas antielusión radica en la reivindicación de los efectos correctores adscritos a los derechos antidumping, entonces no será difícil advertir la conveniencia de la creación de un sistema normativo capaz de brindar las herramientas necesarias para que la autoridad administrativa luche efectivamente contra las negativas consecuencias generadas por las prácticas de elusión.

Por tanto, importa volcar nuestra atención al análisis de los preceptos desarrollados en otras legislaciones entorno a las medidas antielusión, pues la experiencia legal externa nos va a facilitar el desarrollo de ciertos criterios que forjen nuestro sistema. 


\subsection{Normas antielusión en Estados Unidos}

El dispositivo legal que contiene las disposiciones antielusión son encontradas en el Documento de Prevención de la Elusión de Derechos Antidumping 1677j; en dicho instrumento se detallan determinadas cuestiones en torno al procedimiento antielusión. Por un lado, en el sistema norteamericano, el periodo de investigación establecido para los procedimientos antielusión, cualquiera sea el supuesto elusivo, será de 300 días; asimismo, se señala que la función reguladora recae sobre dos autoridades administrativas norteamericanas:

- La Comisión de Comercio Internacional de los Estados Unidos (USITC por sus siglas en inglés): su función se basa en realizar investigaciones para identificar los elementos exigidos en el reglamento que permitan, en su caso, la aplicación por extensión de los derechos antidumping. Una vez que se formulen conclusiones en razón del procedimiento previamente realizado, la Comisión informará sobre sus recomendaciones al Departamento.

- Departamento de Comercio de los Estados Unidos (DOC por sus siglas en inglés): entidad que recoge las investigaciones realizadas por la Comisión y es quien decide o no la extensión de los derechos antidumping aplicados en el procedimiento antidumping original.

Por otro lado, se detallan cuatro supuestos de elusión, cada uno de los cuales contiene una lista de factores que deberán configurarse para que sea posible la aplicación por extensión de los derechos antidumping. A continuación, procederemos a sintetizar los preceptos desarrollados al respecto: 


\subsubsection{Productos completados o ensamblados en los Estados Unidos:}

La autoridad administrativa podrá incluir dentro del alcance de los derechos antidumping a las partes y componentes que son usados para la terminación o ensamblaje de un producto realizado dentro de los Estados Unidos cuando:

- El producto terminado o ensamblado que es vendido en los Estados Unidos es de la misma clase o tipo (producto similar) del producto al que se le aplicó originalmente los derechos antidumping. En este punto, la autoridad deberá analizar la semejanza entre los patrones de intercambio de las partes o componentes y el producto similar; la posible afiliación entre el productor o exportador de las partes o componentes del país extranjero y la persona encargada de ensamblar o completar la mercancía en los Estados Unidos y el incremento de las exportaciones de partes y componentes tras la iniciación del procedimiento antidumping.

- Las partes y componentes, que son usados para terminar o ensamblar el producto final en los Estados Unidos, son producidos en el país extranjero al que se le aplicó las medidas antidumping.

- El proceso de ensamblaje o terminación realizado en los Estados Unidos es insignificante. Para ello, la autoridad tendrá en cuenta el nivel de inversión, la naturaleza del proceso de producción, el nivel de desarrollo y el proceso de producción realizados en los Estados Unidos.

- El valor de las partes o componentes representa una fracción importante respecto al valor total de la mercancía.

\subsubsection{MERCANCÍA COMPLETADA O ENSAMBLADA EN UN TERCER PAÍS:}

La autoridad administrativa, después de lo aconsejado por la Comisión, podrá extender a las mercancías importadas los derechos antidumping si se cumplen los siguientes criterios: 
- Si la mercancía exportada a los Estados Unidos es de la misma clase o tipo (producto similar) de una mercancía producida en un país extranjero (país de origen), sobre el cual se aplican derechos antidumping.

- Antes de la importación dentro de Estados Unidos, aquel producto es completado o ensamblado en un tercer país (país de exportación), sin embargo, la mercancía de la cual se trata, son producidos en un país extranjero (país de origen) al cuál se le aplican derechos antidumping.

- El proceso de ensamblaje o terminación realizado en el tercer país (país de exportación) es menor o insignificante. Para ello, la autoridad tendrá en cuenta el nivel de inversión, de investigación y desarrollo, el nivel del proceso de producción y la extensión de sus instalaciones en el país de exportación.

- El valor de la mercancía producida en el país extranjero (país de origen) al cual se le aplican medidas antidumping es una porción importante del valor total de la mercancía exportada a Estados Unidos.

- Para determinar si se incluye dentro del alcance de las medidas antidumping a las partes y componentes, la autoridad deberá analizar la semejanza entre los patrones de intercambio de las partes o componentes y el producto similar sujeto a derecho antidumping en el país de origen; la posible afiliación entre el productor o exportador de las partes o componentes del país extranjero y la persona encargada de ensamblar o completar la mercancía en el tercer país para luego exportarla a los Estados Unidos y el incremento de las exportaciones a un tercer país de partes y componentes tras la iniciación del procedimiento antidumping.

\subsubsection{ALTERACIONES MENORES DE LA MERCANCÍA:}

La autoridad administrativa deberá tener en cuenta la concurrencia de los siguientes criterios generales 
- La clase o tipo de mercancía sujeto a derecho antidumping y las alteraciones incluidas en el producto en forma y apariencia, independientemente de que se encuentre o no en la misma clasificación arancelaria.

- Sin embargo, no se aplicarán los requisitos generales si la autoridad administrativa determina que es innecesario considerar al producto alterado dentro del alcance de la investigación y la medida.

- Mercancía sujeta a un proceso posterior de desarrollo: la autoridad estadounidense deberá considerar los siguientes supuestos generales

- El producto sujeto a un proceso posterior de desarrollo tiene características físicas equivalentes al producto al cual se le aplicaron originalmente los derechos antidumping.

- Las expectativas desarrolladas por el último comprador, en torno al producto sujeto a un proceso posterior de desarrollo, son las mismas que las del producto original.

- El último uso del producto original y del producto sujeto a un proceso posterior de desarrollo son los mismos. En este punto, la autoridad deberá además determinar si el producto sujeto a un proceso posterior de desarrollo es vendido a través del mismo canal de distribución empleado para el producto original y si el producto sujeto a un proceso posterior de desarrollo es publicitado y distribuido de una manera similar al del producto original.

- La autoridad no dejará de aplicar la medida antidumping a los productos sujetos a un proceso posterior de desarrollo, incluso si éste es clasificado bajo una partida arancelaria distinta a la identificada en la solicitud o permite al comprador ejecutar funciones adicionales.

Para sintetizar lo antes mencionado, la legislación antielusiva norteamericana comprende cuatro supuestos elusivos, cuyos requisitos para su configuración deberán ser analizados por la Comisión. Una vez que ésta haga una determinación positiva sobre la 
conveniencia de inclusión y extensión de los derechos antidumping aplicados originalmente, el Departamento de Comercio se encargará de realizar un fallo final, sobre el respecto.

\subsection{NORMAS ANTIELUSIÓN EN LA UNIÓN EUROPEA}

Resulta preponderante el desarrollo minucioso de este acápite, pues la historia legislativa europea nos deja muchas pautas que serán tomadas en cuenta para, principalmente, alcanzar el objetivo de esta tesis: comentar y realizar recomendaciones al Proyecto de Ley sobre la Modificación del Decreto Supremo N 006-2004. Para el mejor desarrollo y apropiada lectura del presente numeral, procederemos a clasificarlo en dos bloques. El primero de ellos, expondrá las preliminares normas antielusión y la repercusión que éstas tuvieron respecto a otros países; al respecto se analizará el emblemático caso que comprometió a la Unión Europea y Japón ante el GATT (ahora OMC). Posteriormente, se establecerá cómo el Informe Final emitido por el Panel del GATT, sobre el caso anteriormente reseñado, determinó las directrices bajos las que se encauzó las sucesivas normas antielusión de la Unión Europea.

\subsubsection{CASO UNión Europea VS JAPón:}

El 28 de julio de 1984 se emitió el primer instrumento legal destinado a regular y, en su caso, repeler las prácticas dumping; hacemos referencia pues al Reglamento $(\mathrm{CE}) \mathrm{N}^{\circ}$ 2176/84. Éste fue posteriormente modificado por el Reglamento (CE) N ${ }^{\circ}$ 1761/87 del 22 de junio de 1987; al ser el primer dispositivo legal que dispuso normas antielusión, importa resaltar su trascendencia. Aquel Reglamento regulaba la práctica de apertura de una planta dentro de la Comunidad Europea con el fin de ensamblar partes y componentes de un producto que era similar a otro al cual se le aplicaban derechos antidumping; en la medida que se configuraran los criterios preestablecidos en la normativa, esta conducta era condenada por la autoridad administrativa. Cabe precisar, que este Reglamento fue una 
respuesta normativa que se engendró en razón de la coyuntura comercial que la Unión Europea enfrentaba, en ese entonces, con Japón. Posteriormente, el 11 de julio de 1988 se emitió el Reglamento (CE) No 2423/88, el cual se limitaba a recoger, en el Artículo 13:10, las disposiciones desarrolladas por el Reglamento precedente, es decir, se normaba respecto al único supuesto elusivo referente al ensamblaje de partes y componentes, sin embargo, se hacía referencia además a tres criterios:

"Los derechos antidumping definitivos serán impuestos sobre los productos que son introducidos al comercio de la Comunidad después de haberlos ensamblado o producido en la Comunidad, con tal que:

- El ensamblaje o producción sea realizado por una parte relacionada o asociada a cualquiera de los productores quien exporta un producto similar sujeto a un derecho antidumping definitivo.

- $\quad$ El ensamblaje o la operación de producción empezó o se incrementó sustancialmente después de la iniciación de la investigación antidumping.

- El valor de las partes o materiales usados en el ensamblaje o la operación de producción y originarios del país de exportación del producto sujeto a derechos antidumping excede el valor de todas las partes o materiales usados en por lo menos un 50\%"

El Reglamento (CE) $N^{\circ} 1761 / 87$ y el Reglamento (CE) $N^{\circ} 2423 / 88$ se constituían como los cuerpos legales antielusión vigentes, en ese entonces, en la Unión Europea.

Siendo ese el escenario normativo en la Unión Europea, el 29 de julio de 1988 Japón realizó una consulta sobre la legitimidad de las disposiciones antielusión. Ello desembocó, el 09 de mayo de 1989, en el establecimiento de un Panel del GATT, encargado de conocer sobre la solicitud presentada por Japón y analizar los reglamentos de la Unión Europea, relacionados a la importación de partes y componentes. A continuación, presentaremos una reseña realizada en torno al Reporte del Panel del GATT, el cual fue emitido el 22 de marzo de 1990 y adoptado el 16 de mayo de 1990. 
La disputa estaba conformada por el país solicitante, Japón; el país cuya legislación estaba siendo cuestionada, la Unión Europea; y los países que se constituían como terceras partes interesadas, llámese Australia, Canadá, Hong Kong, Corea del Sur, Singapur, y Estados Unidos.

Por un lado, la posición de Japón era la de acusar la disconformidad de la normativa de la Unión Europea respecto a los artículo I, II y III del Acuerdo General sobre Aranceles Aduaneros y Comercio (GATT 1947). Mientras que, por otro lado, la Comunidad revelaba la creciente configuración de prácticas que buscaban eludir los derechos antidumping aplicados o por aplicar. Si bien no existía una base normativa en el marco internacional que tratara concretamente sobre supuestos elusivos y que respalde las disposiciones de la Unión Europea, la Comunidad emitió normas antielusión, pues entendía que éstas podían ser concebidas de acuerdo al Artículo XX (d) del GATT de 1947, y aplicó las medidas antielusión a los productos ensamblados o producidos en la Comunidad y no a las partes que los conformaban.

Según las posiciones y los fundamentos esgrimidos por los países partes de la discusión, el Panel tomó los siguientes elementos como núcleo de pronunciamiento, de acuerdo al numeral 5.3 del Reporte:

- La imposición de medidas de acuerdo con el Artículo 13:10 del Reglamento (EC) $\mathrm{N}^{\circ} 2176 / 84$ y $\mathrm{N}^{\circ} 2423 / 88$ (referido como las medidas antielusión).

- La aceptación de compromisos de acuerdo con el Artículo 13:10 del Reglamento (EC) $\mathrm{N}^{\circ} 2176 / 84$ y N² 2423/88 (referido como compromisos)

- El Artículo 13:10 del Reglamento (EC) N²176/84 y N²423/88 (referido como las previsiones antielusión).

- La no publicación de criterios para aceptar el compromiso respecto a las partes y la administración de las reglas de origen de las partes y materiales. 


\subsubsection{MEDIDAS ANTIELUSIÓN:}

Para determinar qué tratamiento se le otorgaba a las medidas antielusión, el Panel empezó por determinar si éstos caían dentro del concepto de derechos de aduana, de acuerdo al artículo II: 1 (b), o de impuestos internos, de acuerdo al Artículo III: 2. En primera instancia, se concluyó que las medidas antielusión no eran aplicados a la importación de acuerdo a lo prescrito por el Artículo II: 1 (b), pues el trato que la Unión Europea le daba a las partes y materiales sujetos a medidas antielusión no era la de libre circulación, por tanto, las medidas antielusión no se constituían como derechos de aduana. En segundo lugar, el Panel determinó que la aplicación de medidas antielusión a los productos terminados supone asignar indirectamente cargos internos en exceso a las partes y materiales importados, respecto a los productos similares del mercado doméstico, por tanto, el Panel concluyó que las medidas antielusión eran contrarias al Artículo III: 2. Se deduce, finalmente, que el trato que el Panel le da a las medidas antidumping no es la de derechos de aduanas, sino más bien la de impuesto interno. Siendo ello así, el Panel consideró que no era necesario examinar la segunda parte del Artículo III: 2 y del Artículo I, por tanto, se abstuvo de realizar algún pronunciamiento al respecto.

Posteriormente, el Panel procedió a examinar la conveniencia de las medidas antielusión bajo la luz del Artículo XX (d) y el Artículo VI del GATT. Según la defensa esgrimida por la Unión Europea, el fundamento de las medidas antielusión se basaba en lo dispuesto por el Artículo XX (d), el cual señala:

A reserva de que no se apliquen las medidas enunciadas a continuación en forma que constituya un medio de discriminación arbitrio o injustificable entre los países en que prevalezcan las mismas condiciones, o una restricción encubierta al comercio internacional, ninguna disposición del presente Acuerdo será interpretada en el sentido de impedir que toda parte contratante adopte o aplique las medidas: 
d) Necesarias para lograr la observancia de las leyes y de los reglamentos que no sean incompatibles con las disposiciones del presente Acuerdo.

(Acuerdo General sobre Aranceles Aduaneros y Comercio)

Como se desprende de la lectura de dicho artículo, estamos hablando de la aplicación imperiosa de una medida que es contraria a las disposiciones del GATT, pero que es ejecutada con el propósito de hacer cumplir las obligaciones a las que los países miembros se subyugaron en razón de leyes y reglamentos engendrados en armonía con lo estipulado por el GATT. Sin embargo, el límite establecido a esta prerrogativa se constituye en la prohibición de imponer medidas que encubran una conducta de discriminación arbitraria o injustificable.

Según señala el Reporte, si adaptamos lo dispuesto por el Artículo XX (d) con el razonamiento que fundamenta la posición de la Comunidad, podríamos sostener que el símil de "la medida necesaria para lograr la observancia de las leyes y de los reglamentos" hace referencia a la aplicación de medidas antielusión para conseguir el cumplimiento del Reglamento (CE) $\mathrm{N}^{\circ} 2176 / 84$ y del Reglamento (CE) $\mathrm{N}^{\circ}$ 1761/88 (excepto las disposiciones antielusión).

La lectura que la Comunidad realiza respecto al Artículo XX (d) es más bien amplia, pues ésta llega a afirmar que el propósito de la aplicación de las medidas antielusión no se resume solo al cumplimiento de las leyes y reglamentos antidumping, sino que además garantiza el cumplimiento de sus objetivos.

Por otro lado, según el Reporte, Japón argumenta que las medidas antielusión son instrumentos legales que no aseguran el pago de los derechos antidumping y, por tanto, no deberían ser consideradas como medios para el logro de la observancia de leyes y reglamentos antidumping; concluye así que no se justificaría la aplicación de las medidas antielusión de acuerdo al Artículo XX (d). Como se observa, la óptica desde la que Japón analiza el Artículo materia de discusión es más bien restrictiva. 
El Panel se encuentra ante dos interpretaciones disimiles realizadas respecto a una misma disposición legal, el Artículo XX (d). Una, que percibe a las medidas antielusión como fundamentales para asegurar el cumplimiento no solo de las leyes y reglamentos antidumping, sino también de los objetivos establecidos dentro de ellas; y otra, que concibe a las medidas antielusión como insuficientes para lograr la ejecución de normativa antidumping, pues se considera que dichas medidas no garantizan el efectivo pago de los derechos antidumping. Finalmente, el Panel se manifestó señalando que adoptar la posición más amplia significaría generar cierta inseguridad, pues en el supuesto que no se cumplan con los objetivos fijados en las leyes y reglamentos, se estaría permitiendo la aplicación de medidas percibidas como necesarias, pero inconsistentes con las disposiciones del GATT. Adicionalmente, el Panel señaló que las medidas antielusión no cumplían con el requisito establecido por el Artículo XX (d), pues la medida no lograba la observancia de las leyes y reglamentos, al no servir para ejecutar el pago de los derechos antidumping.

Ahora, respecto al Artículo VI, el pronunciamiento del Panel fue más bien vacuo, pero irónicamente ello sirvió de asidero para mantener los propósitos de normar en contra de las conductas elusivas respecto a los derechos antidumping aplicados o por aplicar.

Según comenta Yanning Yu (2008), la Unión Europea no supo encauzar su defensa, pues en un inició señaló que las medidas antielusión pueden ser entendidas como una extensión de los derechos antidumping aplicados al producto final cuyas partes y componentes fueron exportados a la Unión Europea, sin embargo, niega que el Artículo VI ofrezca las bases legales que justifiquen las medidas antielusión, pues la norma que las avalaría seria el artículo XX (d) del GATT.

"Parece ser aparente que los argumentos de la UE son de alguna manera contradictorios. Por un lado, la UE insistió en plantear que las medidas antielusión deberían encontrarse justificadas bajo lo dispuesto por el Artículo XX (d) en la ausencia de disposiciones relevantes en el Artículo VI del GATT y el Código Antidumping de 1979. Sin embargo, por otro lado, la UE remarcó que las medidas antielusión son una extensión de los derechos antidumping, ello cuando defendió 
que tales medidas fueron impuestas en los productos terminados, pero no en sus partes y componentes. Como resultado, si las medidas antielusión son consideradas como una extensión de los derechos antidumping, entonces tales medidas serían esencialmente derechos antidumping y por tanto justificadas de acuerdo al Artículo VI del GATT así como por el Código Antidumping de 1979. (pág. 149)

Si bien es cierto, que el Artículo VI se constituye como una disposición de excepción del libre comercio que encierra y regula específicamente la práctica dumping, ésta no puede explicar de manera plena y en todos sus matices las prácticas de elusión. Así que, si bien es natural pensar que el reenvío lógico que justifique la aplicación de medidas antielusivas sea hacia el Artículo VI del GATT, ésta es incapaz de explicar todos los criterios que encierran una normativa antielusión, ello por ser muy limitada.

Sin embargo, la posición del Panel respecto a la exposición legal realizada por la Unión Europea fue más bien simple; ésta creyó conveniente aplicar dos principios que propugnan el no pronunciamiento por parte de la autoridad sobre fundamentos no alegados por las partes que comprenden el conflicto ni por terceras partes respecto a excepciones establecidas para el GATT.

Por tanto, no se llegó a determinar si las medidas antielusión eran inconsistentes con las normas internacionales de comercio entre naciones. Es decir, el Panel Internacional del GATT tuvo la oportunidad de conocer y resolver sobre el único caso cuya materia de discusión hacía referencia a las medidas antielusión, sin embargo, la motivación que determinó su informe final fue retórica, pues no se llegó a pronunciar sobre el núcleo de la discusión que se refería esencialmente a la armonía que existía entre las medidas antielusión y las normas que la regulaban. Este vacío en el pronunciamiento del Panel sirvió de puente para que los países que apoyan normar contra las prácticas de elusión tengan un sustento para seguir sosteniendo su posición. Es evidente entonces que el Panel no declaró de forma liminar y expresa la inconsistencia de las medidas antielusivas 
respecto al GATT, por tanto, se puede entender que el Reporte Final resulta favorecer más a la Unión Europea que al país asiático.

\subsubsection{ACEPTACIÓN DE COMPROMISOS:}

Uno de los alegatos desarrollados por Japón fue la inconsistencia de la normativa antielusión de la Unión Europea con el Artículo III: 4 del GATT, el cual señala lo siguiente:

Los productos del territorio de toda parte contratante importados en el territorio de cualquier otra parte contratante no deberán recibir un trato menos favorable que el concedido a los productos similares de origen nacional, en lo concerniente a cualquier ley, reglamento o prescripción que afecte a la venta, la oferta para la venta, la compra, el transporte, la distribución y el uso de estos productos en el mercado interior.

(Acuerdo General sobre Aranceles Aduaneros y Comercio)

Según se detalla en el Reporte, las disposiciones antielusión suspenden el procedimiento antielusión cuando se ofrece un compromiso que limita el uso de partes o materiales originarios de Japón, sin embargo, no se imponen las mismas restricciones en el uso de productos similares originarios de la Unión Europea. Al respecto, el Panel concluyó en su Reporte que el tratamiento otorgado a los productos importados es menos favorable que el dado a los productos nacionales de origen nacional.

Finalmente, según el Panel, el Artículo 13:10 dispone un supuesto que permite la suspensión del procedimiento antielusión, el cual se constituye al otorgarse un compromiso direccionado a limitar el uso de partes o materiales originarias de Japón en su ensamblaje u operaciones de producción. Por tanto, se dispone que este extremo del articulado es inconsistente con el Artículo III: 4. 


\subsubsection{Artículo 13:10 de la regulación de la unión europea:}

En este punto, el Panel trae a colación Reportes que se adoptaron en casos anteriormente resueltos; en estos documentos se consideran como una forma de vulnerar Artículo III: 2 del GATT la emisión de normativa con carácter mandatario en los cuales se requiere a la autoridad administrativa la imposición de impuestos internos que buscan discriminar productos importados.

En el caso de autos, Japón solicitó que la Unión Europea revoque las medidas antielusivas aplicadas hasta ese momento y que el Panel le recomiende la revisión y la re redacción de sus disposiciones, pues el país asiático consideró que las medidas concebidas en razón de disposiciones antielusivas y las previsiones en sí mismas violaban las obligaciones establecidas a la Unión Europea como país miembro del GATT.

El Panel consideró los alegatos emitidos por el país asiático y en base a los fundamentos desarrollados en otros Reportes concluyó que las disposiciones bajo cuestionamiento no imponen la aplicación de las medidas antielusivas, sino que, más bien, otorga una prerrogativa a la autoridad administrativa competente a tomar ciertas acciones. Por tanto, se determinó que las disposiciones antielusivas no son contrarias a las obligaciones adscritas a la Unión Europea en su calidad de país miembro del GATT, sin embargo, expresó que resultaría deseable rehacer la normativa para que se encuentre en armonía con el conjunto de mandatos del GATT.

\subsubsection{PUbliCACIONES de CRITERIOS Y REgLAS ADMINISTRATIVAS:}

Una de las obligaciones a las cuales se subyugan los países miembros del GATT, está establecido en el Artículo X: 1:

Las leyes, reglamentos, decisiones judiciales y disposiciones administrativas de aplicación general que cualquier parte contratante haya puesto en vigor (...) serán 
publicados rápidamente a fin de que los gobiernos y los comerciantes tengan conocimiento de ellos.

(Acuerdo General sobre Aranceles Aduaneros y Comercio)

En el caso presentado, la Unión Europea, al emitir una reglamentación que regula las conductas elusivas, debió cumplir con publicar los criterios de aceptación de compromisos adscritos a partes y las reglas administrativas de origen de materiales y partes que iban a ser tomas en cuenta por la autoridad administrativa. Al no cumplir esta obligación, Japón solicitó que el Panel se pronuncie al respecto. Ante ello, el Panel ratificó la falta de publicación de información relevante por parte de la Unión Europea, violando así el Artículo X: 1 y X: 3 del GATT.

Éste fue un caso único y emblemático. La discusión entre la Unión Europea y Japón en referencia a la aplicación de medidas antielusión fue el único que, hasta nuestros tiempos, se entabló ante el Panel del GATT ahora OMC. Asimismo, el Reporte que puso fin al conflicto marcó un hito a nivel internacional, pues los países que contaban con reglamentación antielusiva dispusieron la revisión de sus legislaciones y las ajustaron a las recomendaciones realizadas por los miembros del Panel. Debemos recordar que hubo una inacción decisoria respecto al análisis de las medidas antielusión bajo la luz del Artículo VI del GATT, cuyas disposiciones, según Estados Unidos el cual participó como tercera parte, se constituyen como la base legal que explica la conveniencia de las medidas antielusivas. Ahora bien, si la mayor autoridad internacional se inhibió de tildar expresamente a las medidas antielusivas de ilegales de acuerdo al Artículo VI, cuyos preceptos vienen a colación en supuestos de dumping, entonces, mal harían los países que se manifiestan en desacuerdo de dichas medidas en acusarlas de inconsistentes con el GATT. Podría decirse que la falta de pronunciamiento favorece, en este caso, a los países con intenciones de normar en contra de las prácticas elusivas, siempre, claro está, que tengan en cuenta las recomendaciones realizadas por el Panel. Como bien concluye Yanning Yu (2008), al respecto: 
El Screwdriver Case no debería ser visto como una victoria para los países que se oponen a las medidas antielusión, ya que, prácticamente no existen evidencias sólidas para votar a favor de la ilegalidad de tales medidas. En vista de ello, la conclusión final, de facto, es bastante opuesta. Se han proporcionado argumentos para los miembros de la OMC para creer que sus disposiciones nacionales contra la elusión son adecuadas y lícitas. (pág. 161)

\subsubsection{REGLAMENTOS VIGENTES EN LA UNIÓN EUROPEA:}

Actualmente, en la Unión Europea rige el Reglamento (CE) N ${ }^{\circ}$ 1225/2009 del Consejo de 30 de noviembre de 2009, relativo a la defensa contra las importaciones que sean objeto de dumping por parte de países no miembros de la Comunidad Europea; específicamente el Artículo 13, del citado dispositivo, reúne los cuatro supuestos elusivos que anteriormente se encontraban disgregados en El Reglamento (CE) N ${ }^{\circ}$ 384/1996, el cuál comprendía el Artículo 13:2, y el Reglamento (CE) N 461/2004, el cuál comprendía los Artículos 13: 1, 13: 3 y 13: 4.

El Artículo 13 del Reglamento (CE) N 1225/2009 empieza estableciendo una definición de lo que se entiende por elusión de derechos antidumping, para ello, se esgrimen diferentes condiciones que deberán configurarse y ser analizados por la autoridad administrativa. Posteriormente, en el primer y segundo numeral del citado Reglamento, las primeras aproximaciones conceptuales, establecidas de forma general, aterrizan concretamente en cuatro supuestos elusivos. Finalmente, en los numerales siguientes, se detallan ciertas reglas procedimentales que deberán ser tomadas en cuenta por la autoridad y administrados. A continuación, desarrollaremos con mayor detalle el contenido del Reglamento que nos trae.

En el Artículo 13, primer numeral, se contemplan los criterios bajos los cuales se configura una práctica elusiva. Vale precisar que la definición que se presentará ha sido replicada además en otras legislaciones. 
Se entenderá que existe elusión cuando produzca un cambio de características del comercio entre terceros países y la Comunidad o entre empresas individuales del país sujeto a las medidas y la Comunidad, derivado de una práctica, proceso o trabajo para el que no exista una causa o una justificación económica adecuadas distintas del establecimiento del derecho y haya pruebas del perjuicio o de que se están burlando los efectos correctores del derecho por lo que respecta a los precios y/o las cantidades del producto similar y existan pruebas de dumping en relación con los precios normales previamente establecidos para los productos similares. (Reglamento (CE) N 1225/2009)

Ahora bien, según suscribe el Reglamento, el plazo estimado para la terminación del procedimiento administrativo por prácticas elusivas es de 09 meses. Mientras que, el inicio de la investigación se dará por iniciativa de la Comisión, a solicitud de un Estado Miembro o cualquier parte interesada. La legislación europea desarrolló cuatro supuestos que suponen la realización de prácticas elusivas:

- Modificaciones menores para alterar el código aduanero, siempre que ello no altere las características esenciales del producto.

- Envío del producto con derechos antidumping a través de terceros países.

- Reorganización por los productores o exportadores de sus canales de venta en el país sujeto a las medidas con el fin de que sus productos sean exportados a la Comunidad a través de productores que son beneficiarios de un tipo de derecho individual inferior al aplicable a los productos de los fabricantes.

- Montaje de partes en la Comunidad o terceros países. En el caso de este supuesto se exigirá la existencia de determinados criterios, tales como el comienzo o incremento de las operaciones elusivas desde el momento de apertura de la investigación antidumping o justo antes de su apertura; la constitución del $60 \%$ o más del valor total de las partes del producto montado, no obstante, no se 
considerará que existe elusión cuando el valor añadido conjunto de las partes utilizadas durante la operación de montaje sea superior al 25\% del coste de producción; la existencia de pruebas de dumping y evidencia de que los efectos correctores del derecho antidumping estén siendo burlados.

Como se observa, el Reglamento 1225/2009 es el resultado de las revisiones, modificaciones realizadas a la normativa antielusión originaria y en base a las recomendaciones que en su momento realizó el Panel del GATT. Tal es la importancia de los matices desarrollados entorno a las medidas elusivas en la legislación europea que muchos otros países las han replicado en sus legislaciones internas. En nuestro caso, resulta conveniente tomar algunos criterios e incluirlos en nuestro proyecto modificatorio del Decreto Supremo N ${ }^{\circ}$ 006-2004, mas ello será materia del siguiente capítulo.

\subsection{NORMAS ANTIELUSIÓN EN ARGENTINA}

El Decreto $N^{\circ} 1393 / 2008$, la cual contiene disposiciones reglamentarias y de implementación destinadas a la efectiva aplicación de la Ley $\mathrm{N}^{\circ} 24.425$, es el dispositivo legal encargado de regular las prácticas dumping y, específicamente, el capítulo IX dispone las reglas aplicables en contra de las prácticas que eluden el pago de las medidas antidumping.

Para iniciar un procedimiento antielusión, una solicitud podrás ser entablada a pedido de parte, de oficio o a propuesta de la Subsecretaría de Política y Gestión Comercial y/o de la Comisión Nacional de Comercio Exterior. Cualquiera sea la forma en la que se inicie la investigación, se deberá contar con elementos de prueba suficientes que expongan la posible realización de una práctica de elusión.

Una vez que se tenga por admitida la solicitud de investigación, la Subsecretaría y/o la Comisión contarán con 120 días para realizar sus investigaciones y elevas sus 
conclusiones a la Secretaría de Industria, Comercio y de la Pequeña y Mediana Empresa, la cual cuenta con 10 días, desde recepcionado los informes de investigación, para elevar sus conclusiones al Ministerio de Economía y Producción, quien, después de 20 días, se encargará de expedir un informe final.

Ahora bien, los supuestos elusivos esgrimidos en el artículo 59 de dicho instrumento legal se refieren a:

- La exportación de partes y piezas que serán montados en Argentina, siendo ésta un producto similar al investigado.

- La exportación de partes y piezas a un tercer país en donde se las ensambla para exportarlas posteriormente a Argentina, el cual será un producto similar al investigado.

- Cualquier otra práctica que burle los efectos de los derechos antidumping, revistiendo un cambio de características del comercio entre terceros países y Argentina, para la cual no existe una justificación económica adecuada distinta de la imposición del derecho.

De acuerdo a la lectura de las disposiciones argentinas, podemos emitir las siguientes conclusiones.

- En primera instancia, la normativa aplicable en caso de elusión, será el capítulo IX del Decreto $N^{\circ} 1393 / 2008$, emitido el 03 de setiembre de 2008.

- Las labores derivadas de la investigación por prácticas dumping y actividades elusivas no se concentran en una sola autoridad administrativa, como en el caso peruano, sino que estos quehaceres se diversifican y recaen bajo la dirección de cuatro funcionarios. Por su parte, el Ministerio de Economía y Producción se 
encargará de resolver la conveniencia o no de la aplicación de medidas antidumping y antielusión.

- A diferencia de otras legislaciones, la normativa argentina permite el inicio del procedimiento antielusión por solicitud de parte y de oficio.

- Las disposiciones no establecen la obligación de probar la existencia de precios dumping, de daño a la rama de producción nacional y nexo causal. Entendemos que estos criterios no son exigidos porque formaron parte de la investigación antidumping realizadas originalmente.

- Se instaura el mismo procedimiento administrativo para los dos supuestos elusivos derivados del ensamblaje de partes y piezas realizado en Argentina y en un tercer país.

- De acuerdo al cómputo total de los plazos dispuestos para cada etapa del procedimiento administrativo, concluimos que el periodo total de la investigación antielusión es de 150 días. Resulta pues más expedito que el procedimiento norteamericano y europeo.

\subsection{NORMAS ANTIELUSIÓN EN COLOMBIA}

El Decreto $\mathrm{N}^{\circ} 2550$ de 15 de julio de 2010 es el instrumento legal que regula la aplicación de derechos antidumping en Colombia; específicamente, la sección segunda formula los criterios necesarios para la aplicación de medidas antielusión. Para efectos de graficar de la mejor manera el contenido de dichos preceptos procederemos a clasificarlos en los siguientes rubros: definición, supuestos de elusión y consecuencias legales de su aplicación.

En primera instancia, se entiende que existe una práctica elusiva cuando, derivado de una práctica, procesos o trabajo, se produce un cambio de características del comercio 
entre el país sujeto a derecho antidumping o de terceros países y Colombia. Asimismo, se devela una conducta desleal plausible de aplicación de medidas antielusión cuando no impere una justificación económica que justifique la ejecución de prácticas elusivas y existan pruebas suficientes de que dicha conducta solo buscan anular los efectos correctores de los derechos antidumping

A diferencia de otras legislaciones, en la normativa colombiana solo se reconocen dos supuestos elusivos derivados de operaciones de montaje ejecutados en Colombia o en un tercer país para después exportarlos al país de destino, Colombia. Según señala el artículo 53, la autoridad administrativa deberá tener en cuenta los siguientes criterios:

- Importaciones, procedentes del país sujeto al derecho, de otro producto que tiene las mismas características y usos generales que el producto considerado.

- Las piezas y componentes provienen del país de origen el cual se encuentra sometido a la aplicación vigente de medidas antidumping, del exportador o del productor o de una parte del país exportador que suministra en nombre del exportador o productor.

- El producto montado o terminado con esas piezas o componentes en Colombia, es similar al producto objeto de derechos definitivos.

- Existen pruebas de dumping en el producto producido con estas piezas, resultante de comparar el precio del producto una vez montado o terminado en Colombia o en un tercer país y el valor normal previamente establecido del producto similar, cuando fue sometido al derecho antidumping.

- La operación comenzó o se incrementó sustancialmente desde el momento de apertura de la investigación antidumping o justo antes de su apertura. 
- Las partes constituyen el $60 \%$ o más del valor total de las piezas del producto montado, mas no habrá elusión si el valor añadido del conjunto de las partes sea igual o mayor al $40 \%$ del costo de producción o cumpla con la regla de origen.

En caso se reconozcan elementos de prueba suficientes capaces de poner en manifiesto una actitud elusiva, la Dirección de Comercio Exterior de Colombia emitirá una resolución motivada ampliando la aplicación de derechos antidumping a la importación de productos similares o de partes procedentes de terceros países o del país al que originalmente se aplicaron las medidas no arancelarias.

De la lectura de la normativa antielusión de Colombia podemos puntualizar las siguientes conclusiones:

- El Decreto $\mathrm{N}^{\circ} 2550$, en su sección II establece una definición que comprende diversas condiciones que determinan la existencia de prácticas antielusión.

- Se reconocen solo dos supuestos de elusión referidos a la exportación de piezas o componentes a Colombia o a un tercer país. Cabe precisar que no existe una cláusula general que permita la extensión de los derechos antidumping respecto a nuevos supuestos elusivos no determinados expresamente en dichas disposiciones, por tanto, en base al principio de legalidad, la autoridad administrativa solo podría ampliar el margen de aplicación de las medidas antidumping en situación de ensamblaje de partes y componentes.

- La normativa limita el quehacer de la autoridad administrativa al establecer tres condiciones que prescriben la no aplicación de medidas antielusión: cuando las partes o pieza representen menos del $60 \%$ del producto terminado, cuando el valor añadido por las partes en la operación de montaje sea igual o superior al $40 \%$ del costo de producción o cuando se cumpla con las reglas de origen. 
- Según lo dispuesto por la legislación antielusión, el procedimiento de investigación solo podrá ser iniciado mediante solicitud de parte. Como podrá notarse se anula cualquier intervención de oficio.

- De la lectura de sus disposiciones se desprende la exigencia de analizar la existencia de precios dumping que resulta de la diferencia entre el valor normal establecido en la investigación antidumping realizada originalmente y el precio de exportación del producto montado o ensamblado, mas no requiere el examen de existencia de daño o nexo causal.

- No se fijan plazos entorno al procedimiento antielusión, por tanto, ante el vacío legal, se aplicarán supletoriamente el periodo de 18 meses establecido para las investigaciones antidumping.

\subsection{NORMAS ANTIELUSIÓN EN EL MARCO DE LA COMUNIDAD ANDINA DE NACIONES}

La Comunidad Andina de Naciones ${ }^{41}$ (en adelante, CAN) es un organismo que se encuentra conformada por cuatro países Bolivia, Colombia, Ecuador y Perú, los cuales se encuentran sujetos a las disposiciones de la Decisión 456, norma destinada a prevenir las distorsiones en la competencia generadas por prácticas de dumping en importaciones de productos originarios de países miembros de la Comunidad Andina. Importa resaltar que el margen de aplicación del citado instrumento legal se desarrollará en torno a las importaciones originarias de los países miembros y las medidas correctivas se adoptarán para prevenir daños a la rama de producción de un país miembro.

Dentro de la Decisión 456, en el capítulo VIII, se despliegan los artículos aplicables a supuestos de elusión. En este acápite se establecen los criterios que disponen la configuración de una práctica elusiva, tales como el cambio en el comportamiento de las

${ }_{41}$ Como se señala en su página web, la CAN (s.f.) se autodefine como "una comunidad de países unidos voluntariamente con el objetivo de alcanzar un desarrollo integral, más equilibrado y autónomo, mediante la integración andina, suramericana y latinoamericana" 
importaciones del producto similar objeto de medidas, de sus partes, piezas o componentes; la falta de justificación económica que expliquen la ejecución de dichas prácticas y la existencia de pruebas que expongan la eliminación de los efectos correctores de las medidas antidumping.

Cuando existan elementos de prueba capaces de acreditar la ejecución de prácticas elusivas, una solicitud podrá ser entablada por la rama de producción nacional afectada o en nombre de ella o a través de los organismos nacionales de integración de los países miembros de la CAN. Dicho trámite será realizado ante la autoridad administrativa competente para resolver casos de dumping y elusión, función que se instaura en torno a la Secretaría General de la CAN. En caso se determine la conveniencia de la apertura e iniciación de la investigación antielusión, el órgano administrativo deberá emitir una resolución motivada exponiendo sus razones. Después de ello, la autoridad contará con dos meses, prorrogables por un mes, para determinar la existencia de algún supuesto elusivo para lo cual se emite una segunda resolución motivada, la cual determinará, como efecto, la extensión y aplicaciones de los derechos a antidumping que se aplicó originalmente al producto similar.

Esta normativa es, sin embargo, limitada, pues el artículo 75 solo contempla un supuesto elusivo que hace referencia a la operación de ensamblaje o montaje en el país miembro importador. Para estos efectos, la Secretaría General de la CAN deberá determinar la existencia de los siguientes criterios:

- La práctica, proceso o trabajo del que deriva una operación de ensamblaje o montaje comenzó o se incrementó sustancialmente después del inicio de la investigación antidumping.

- Al igual que la legislación europea y colombiana, se establece una condición que limita la aplicación de medidas antielusión. La primera de ellas se refiere a que las partes constituyan el $60 \%$ o más del valor total del producto ensamblado o montado. Por otro lado se considerará que no existe elusión cuando el valor añadido 
al conjunto de las partes utilizadas, en el ensamblaje o montaje, sea superior al $25 \%$ del costo de producción.

- Existen pruebas de que las operaciones realizadas burlan los efectos correctores de los derechos antidumping aplicados originalmente.

- Durante el procedimiento antielusión se deberá comprobar la existencia de precios dumping.

En base a lo esbozado líneas arriba, respecto a las disposiciones de la Decisión $\mathrm{N}^{\circ}$ 456, podemos precisar las siguientes conclusiones:

- El artículo 74 del capítulo VIII de la Decisión $\mathrm{N}^{\circ} 456$ establece los criterios que determinan la existencia de prácticas antielusión.

- A diferencia de otras legislaciones, la normativa de la CAN resulta ser muy limitada, pues ésta fórmula solo un supuesto elusivo el cual hace referencia al ensamblaje o montaje de partes dentro de un país miembro. Tampoco se ha dispuesto una cláusula general que haga posible la aplicación de medidas antielusivas ante supuestos no dispuestos literalmente.

- La normativa determina el inicio de la investigación antielusión mediante solicitud de parte; observamos, por tanto, que no podría iniciarse un procedimiento de oficio.

- Una de las exigencias establecidas para la autoridad administrativa, se constituye en la obligación de demostrar la existencia de precios dumping, sin embargo, no se hace referencia alguna sobre la demostración del daño.

- Creemos que esta normativa es insuficiente, limitada y ambigua. El procedimiento antielusión resulta ser muy escueto, los plazos muy cortos y las disposiciones no cubren todos los supuestos elusivos configurados en el marco del comercio internacional. 
Tabla 5.1.

Resumen sobre los datos en los procedimientos antidumping de legislaciones comparadas.

\begin{tabular}{|c|c|c|c|c|c|c|}
\hline PAÍS & LEGISLACIÓN & FECHA DE PUBLICACIÓN & $\begin{array}{c}\text { AUTORIDAD } \\
\text { ADMINISTRATIVA }\end{array}$ & $\begin{array}{c}\text { INICIO PREVIA SOLICITUD } \\
\text { DE: }\end{array}$ & SUPUESTOS DE ELUSIÓN & $\begin{array}{l}\text { PERIODO DE } \\
\text { PROCEDIMIENTO } \\
\text { ANTIELUSIÓN }\end{array}$ \\
\hline Argentina & $\begin{array}{l}\text { Decreto } \mathrm{N}^{\circ} 1393 / 2008 \\
\text { Normas } \\
\text { Reglamentarias y de } \\
\text { implementación } \\
\text { destinadas a la } \\
\text { efectiva a plicación de } \\
\text { la Ley } \mathrm{N}^{\circ} 24.425 \text {. }\end{array}$ & $\begin{array}{l}03 \text { de setiembre de } \\
2008 .\end{array}$ & $\begin{array}{l}\text {-Subs ecreta ría de } \\
\text { pol ítica y ges ti ón } \\
\text { comercial. } \\
\text { - Comisión Nacional de } \\
\text { Comercio Exterior. } \\
\text { - Secretaría de Industria, } \\
\text { Comercio y de la } \\
\text { Pequeña y Mediana } \\
\text { Empresa. } \\
\text { - Ministerio de } \\
\text { Economía y producción. }\end{array}$ & $\begin{array}{l}\text { - Pedido de parte. } \\
\text { - De oficio (a } \\
\text { propuesta de la } \\
\text { Subsecretaría y/o de la } \\
\text { Comisión). }\end{array}$ & $\begin{array}{l}\text { 1. Se exporten partes y piezas } \\
\text { que serán montado en } \\
\text { Argentina, siendo ésta un } \\
\text { producto similar al investigado } \\
\text { en el proceso antidumping } \\
\text { original. } \\
\text { 2. Se exporten partes o } \\
\text { piezas a un tercer país para ser } \\
\text { ensambladas y, posteriormente, } \\
\text { ser exportadas a Argentina. }\end{array}$ & 150 días. \\
\hline Colombia & $\begin{array}{l}\text { Decreto } \mathrm{N}^{\circ} 2550 \text { por el } \\
\text { cual se regula la } \\
\text { aplicación de derechos } \\
\text { antidumping }\end{array}$ & 15 de julio de 2010 & $\begin{array}{l}\text { - Dirección de } \\
\text { Comercio Exterior. }\end{array}$ & - Solicitud de parte. & $\begin{array}{l}\text { - Operación de ensamblaje o } \\
\text { montaje en Colombia o un } \\
\text { tercer país. }\end{array}$ & 18 meses \\
\hline $\begin{array}{c}\text { Comunidad Andina de } \\
\text { Naciones }\end{array}$ & $\begin{array}{l}\text { Decisión } 456 \text { Normas } \\
\text { para prevenir las } \\
\text { distorsiones en la } \\
\text { competencia } \\
\text { generadas por } \\
\text { prácticas de dumping } \\
\text { en importaciones de } \\
\text { productos originarios } \\
\text { de países miembros de } \\
\text { la Comunidad Andina. }\end{array}$ & 04 de mayo de 1999. & $\begin{array}{l}\text { - Secretaría General } \\
\text { de la Comunidad } \\
\text { Andina. }\end{array}$ & $\begin{array}{l}\text { - Rama de } \\
\text { Producción Nacional } \\
\text { afectada o en nombre } \\
\text { de ella. } \\
\text { - Países Miembros } \\
\text { a través de sus } \\
\text { organismos nacionales } \\
\text { de integración. }\end{array}$ & $\begin{array}{l}\text { - Operación de ensamblaje o } \\
\text { montaje en el país miembro } \\
\text { importador. }\end{array}$ & $\begin{array}{c}02 \text { meses, prorroga } \\
\text { bles en } 01 \text { mes adici } \\
\text { onal. }\end{array}$ \\
\hline Estados Unidos & $\begin{array}{l}1677 \text { j Prevención de } \\
\text { el usión de las medidas } \\
\text { antidumping. }\end{array}$ & 17 de junio de 1930 & $\begin{array}{l}\text { - Comisión de } \\
\text { Comercio Internacional } \\
\text { de los Estados Unidos } \\
\text { (USITC por sus siglas en } \\
\text { inglés). } \\
-\quad \text { Departamento de } \\
\text { Comercio de los Estados } \\
\text { Unidos (DOC por sus } \\
\text { siglas en inglés). }\end{array}$ & $\begin{array}{l}\text { - De oficio (por la } \\
\text { autoridad } \\
\text { administrativa: } \\
\text { Secretario de } \\
\text { Comercio). } \\
\text { - Solicitud de } \\
\text { industrias regionales }\end{array}$ & $\begin{array}{l}\text { Productos completados o } \\
\text { ensamblados in Estados } \\
\text { Unidos. } \\
\text { 3. Mercancía completada o } \\
\text { ensamblada en un tercer país. } \\
\text { 4. Alteraciones menores de } \\
\text { la mercancía. } \\
\text { 5. Mercancía sujeto a un } \\
\text { proceso posterior de } \\
\text { desarrollo. }\end{array}$ & 300 días \\
\hline Unión Europea & $\begin{array}{l}\text { Reglamento (CE) } \mathrm{N}^{\circ} \\
1225 / 2009, \\
\text { modificado por el } \\
\text { Reglamento (CE) } \mathrm{N}^{\circ} \\
1168 / 2012 \text { del } \\
\text { Parlamento Europeo y } \\
\text { del Consejo. }\end{array}$ & $\begin{array}{l}30 \text { de noviembre del } \\
2009 \text { y } 12 \text { de diciembre } \\
\text { del } 2012 \text {, } \\
\text { res pectivamente. }\end{array}$ & - Comisión Europea. & $\begin{array}{l}\text { - De oficio (por la } \\
\text { Comisión). } \\
-\quad \text { Solicitud de un } \\
\text { Estado Miembro. } \\
-\quad \text { Cualquier parte i } \\
\text { nteresada. }\end{array}$ & $\begin{array}{l}\text { 1. Modificaciones menores } \\
\text { para alterar el código } \\
\text { aduanero, siempre que ello no } \\
\text { altere las características } \\
\text { esenciales. } \\
\text { 2. Envío del producto con } \\
\text { derecho antidumping a través } \\
\text { de terceros países. } \\
\text { 3. Reorganización por los } \\
\text { productores o exportadores de } \\
\text { sus canales de venta para } \\
\text { beneficiarse de un derecho } \\
\text { individual inferior. } \\
\text { 4. Montaje de partes y } \\
\text { componentes en la Comunidad } \\
\text { o un tercer país. }\end{array}$ & 09 meses \\
\hline
\end{tabular}

Fuente: Decreto $N^{\circ} 1393 / 2008$, Decreto $N^{\circ} 2550$, Decisión 456, 1677j Prevención de elusión de las medidas antidumping, Reglamento (CE) $\mathrm{N}^{\circ} 1225 / 2009$.

Elaboración: por mí 


\section{Capítulo VI}

\section{PRÁCTICAS DE ELUSIÓN Y MECANISMOS ANTIELUSIVOS}

\subsection{LEGISLACIÓN ANTIELUSIVA NACIONAL}

En nuestro país, la Comisión de Dumping, Subsidios y Eliminación de Barreras no Arancelarias del INDECOPI ha proyectado la problemática de las prácticas de elusión en solo un artículo del Reglamento Antidumping. Este dispositivo hace referencia a uno de los supuestos de elusión que se aplicará solo en la importación de partes piezas o componentes:

Artículo 58.- Aplicación de derechos antidumping o compensatorios sobre la importación de partes piezas o componentes.- La Comisión podrá aplicar derechos antidumping o compensatorios, provisionales o definitivos, sobre la importación de partes, piezas o componentes provenientes del país de origen del producto final sujeto a derechos definitivos, cuando existan evidencias de que tales importaciones se realizan con la finalidad de eludir la aplicación de derechos antidumping o compensatorios impuestos al producto final. Para tal efecto la Comisión tendrá en cuenta entre otros factores:

a) Si el producto vendido en el Perú hubiera sido montado o terminado en el Perú con partes, piezas o componentes producidos en el país de origen del producto final sujeto a derechos definitivos. 
b) Si el producto vendido en el Perú hubiera sido montado o terminado en un tercer país con partes, piezas o componentes producidos en el país de origen del producto final sujeto a derechos definitivos.

c) Si el montaje o terminación hubiera sido efectuada por una parte que está vinculada al exportador o productor del producto final sujeto a derechos definitivos.

d) Si las importaciones de partes, piezas o componentes del producto sujeto a derechos definitivos y las operaciones de ensamble o terminación de dichos productos, han aumentado después de la publicación de la Resolución que da inicio a la investigación.

e) Cualquier otra circunstancia que determine un cambio en las características del comercio, para el que no exista una causa o una justificación económica distinta de la imposición del derecho, y haya pruebas de que se está eludiendo el pago de los derechos definitivos impuestos al producto final.

(Decreto Supremo Nº06, 2003)

Lo cierto es que este artículo es muy limitado, primero, porque no se establece un procedimiento administrativo especial para extender la aplicación de derechos antidumping en caso de elusión, sino que hace un simple reenvío a las disposiciones establecidas en los artículos 21 al 57 del mismo Reglamento. Ahora, en el aspecto comercial, la elusión se ha diversificado en diversas conductas, tales como la importación del producto final a un tercer país; la alteración insignificante, pero suficiente para modificar la partida arancelaria del producto al que se le aplicó originalmente derechos antidumping; la importación ya no del producto final, sino de sus partes o componentes en un tercer país o al país de destino para su ensamblaje, entre otros. Lo cierto es que cada vez se van configurando más supuestos de elusión por parte de los exportadores, por tanto, mal se haría en repeler las prácticas elusivas de forma tan limitada, pues finalmente la única disposición que lo regula, no refleja la complejidad de la problemática.

Una clara consecuencia de la limitada disposición antielusión es que se reduce la capacidad de acción y sanción de la autoridad administrativa. Cabe reconocer que existe casuística que evidenciaría un posible accionar elusivo, sin embargo, en las oportunidades 
en las que la Comisión extendió los derechos antidumping por elusión, el Poder Judicial resolvió declarar nula la Resolución Administrativa Final y exigió levantar la medida, pues se consideró que la sanción violaba el principio de legalidad, en la medida de que no existe una norma primaria antielusión que desencadene la aplicación de la norma secundaria (normas que sancionan el incumplimiento de las normas primarias) que extiende la aplicación de derechos antidumping.

Por tanto, la problemática en este caso radica en el evidente vacío legal que limita el correcto accionar de la Comisión de Dumping, Subsidios y Eliminación de Barreras no Arancelarias, respecto a su función de eliminar las distorsiones en el comercio internacional como lo son las prácticas elusivas de derechos antidumping. Esta falencia normativa implica además un riesgo en el sistema antidumping, pues la percepción que se proyectará en los operadores de la industria doméstica es que la autoridad administrativa es incapaz de hacer efectivo los efectos correctores impuestos mediante la aplicación de los derechos antidumping, anulando la protección de determinada industria frente a un daño, consecuentemente, se desincentivará la participación en la denuncia de prácticas dumping.

Por todo ello, creemos que es menester modificar nuestro Reglamento Antidumping y adecuarlo a la coyuntura de comercio internacional que enfrentamos.

\subsection{Casos de elusión en el Perú}

Lo cierto es que se ha ido desarrollando una corriente dirigida a cuestionar la aplicación de las medidas antielusivas. Entre los estudiosos que comparten dicha postura encontramos a Andrés Calderón (2011), quien señala que "a pesar de que algunos países han implementado normas nacionales para detectar y evitar los casos de elusión, en el Perú no existe suficiente información que evidencie que tales prácticas se están presentando". Al respecto, me gustaría puntualizar las siguientes objeciones. En primer lugar, recordemos que históricamente el fenómeno elusivo se destapó formalmente ante el GATT/OMC en 1988 con el conflicto producido entre la Unión Europea y Japón, por tanto, podría decirse que el 
ejercicio de prácticas elusivas está generando una problemática que acompaña la coyuntura del comercio internacional desde el siglo XX. Ahora, si bien no existe una normativa que uniformice la aplicación de las medidas antielusión entre los diversos países, la OMC no ha negado la existencia de este fenómeno ni la casuística que ella ha originado alrededor del mundo. Además, resulta inexacto afirmar que no existe información que demuestre la ejecución de prácticas elusivas en nuestro país, pues basta con explorar la casuística que, al respecto, se ha ventilado ante la Comisión de Dumping, Subsidios y Eliminación de Barreras no Arancelarias del INDECOPI. Por ello, justamente, procederemos a analizar los fundamentos de hecho y derecho que constituyen la base de cada discusión en torno a los comportamientos de elusión.

\subsubsection{Caso Planchas de YeSO:}

Tras la solicitud presentada por la empresa peruana Drywall S.A. y mediante Resolución N 033-2002/CDS-INDECOPI, la Comisión dispuso, el 11 de julio de 2002, el inicio de una investigación antidumping en contra de las importaciones de planchas de yeso, provenientes de las empresas chilenas Sociedad Industrial Romeral S.A. y El Volcán S.A.

El 06 de febrero de 2003, un estudio realizado por la Comisión y detallado en la Resolución 012-2003/CDS-INDECOPI, concluyó en la determinación preliminar positiva de los tres elementos exigidos en el Acuerdo Antidumping y Reglamento Antidumping: margen dumping, daño a la rama de producción nacional y relación de causalidad entre el dumping y el daño; ello motivó la aplicación de derechos antidumping provisionales.

El proceso de investigación finalizó, en primera instancia administrativa, con la emisión de la Resolución 064-2003/CDS--INDECOPI, el cual declara infundada la solicitud realizada por la empresa peruana DRYWALL S.A. en contra de las importaciones de planchas de yeso regulares de diferentes espesores, provenientes de Chile. Este fallo se fundó, principalmente, en la ausencia de relación causal entre el daño sufrido y el margen dumping calculado. 
La denunciante apeló dicha decisión y ventiló el caso ante el Tribunal de Defensa de la Competencia y de la Propiedad Intelectual, el cual emite, en segunda instancia administrativa, la Resolución Final que dispone:

Revocar la Resolución 064-2003/CDS-INDECOPI que declaró infundada la solicitud interpuesta por la empresa Drywall S.A. (...), y reformándola, ordenar la aplicación de derechos antidumping definitivos a las importaciones de planchas de yeso regulares de espesor mayor o igual a 12,70 mm, originarios de la República de Chile, producidos y/o exportados por Sociedad Industrial Romeral S.A. y por la Compañía Industrial El volcán S.A.

(Resolución 0109-2004-TDC-INDECOPI)

Con el fallo de la Sala de Defensa de la Competencia se agotó la vía administrativa y se dio por culminado el caso. Sin embargo, una año después de emitida la Resolución Final, la autoridad se percató que las importaciones de las planchas de yeso con un espesor $12,50 \mathrm{~mm}$, originarias de Chile se estaba incrementando de forma importante, mientras que las importaciones de las planchas de yeso de espesor mayor o igual a 12,70 mm iban disminuyendo.

Las circunstancias del caso evidencian un supuesto de elusión que se caracteriza por la importación de un producto, sujeto al pago de derechos antidumping, que ha sufrido una alteración mínima pero suficiente para alterar la mercancía. Esta modificación puede implicar o no la variación de la partida arancelaria, sin embargo, lo que caracteriza esta fórmula elusiva es que, a pesar de la alteración, se mantiene las características esenciales del producto. En el caso, materia de análisis, el exportador chileno buscaría evitar el pago de los derechos antidumping, mediante la modificando en el espesor de las planchas de yeso de $12,70 \mathrm{~mm}$ a $12,50 \mathrm{~mm}$. La alteración es nimia, pero suficiente para eludir el pago de las medidas antidumping.

Por ello, el Tribunal de Defensa de la Competencia y de la Propiedad Intelectual se apoyó en Aduanas para extender la aplicación y el cobro de la medida de defensa comercial a las plancha de yeso de $12,50 \mathrm{~mm}$, originarias de los exportadores chilenos. 
La causa se judicializó, pues los exportadores chilenos manifestaron su disconformidad con la decisión tomada por el Tribunal de INDECOPI. El caso siguió su curso y ésta fue resuelta por la Corte Suprema el 2008; el fallo anuló la Resolución administrativa, que extendía la aplicación de los derechos antidumping a las planchas de yeso de espesor 12,50, por considerar que no existía una base legal que establezca taxativamente la extensión de medidas antidumping en supuestos de elusión.

A pesar de converger criterios que evidenciarían la ejecución de una fórmula elusiva, la autoridad se vio impedida de ejercer alguna medida en contra, pues existe un vacío legal que limita el quehacer de INDECOPI y Aduanas.

\subsubsection{Caso Vasos De POLYPAPEL:}

Uno de los conflictos, sobre prácticas elusivas, que la Comisión de Dumping, Subsidios y Eliminación de Barreras no Arancelarias conoció recientemente fue el Caso Tejido Tipo Popelina. La empresa Perú Cups S.A. solicitó el 18 de setiembre del 2001 el inicio de una investigación antidumping en contra de las importaciones chilenas de vasos de papel cartón con polietileno (en adelante vasos de polypapel), realizadas por la compañía Food Pack S.A.

El 29 de noviembre de 2001, la Comisión decide dar inicio al procedimiento antidumping, mediante Resolución $\mathrm{N}^{\circ}$ 028-2001/CDS-INDECOPI, teniendo como foco de investigación al producto con subpartida arancelaria 4823.60.00.00. 89.

Durante el curso de la investigación y con el fin de eliminar las distorsiones generadas por la ejecución de conductas dumping, el 22 de marzo de 2002 la autoridad administrativa ordenó la aplicación de derechos antidumping provisionales sobre los vasos de polypapel importados desde Chile, debido a que se emitió una determinación preliminar positiva de dumping, daño a la rama de producción nacional y nexo causal. 
Sin embargo, en esta etapa de la investigación, la empresa denunciada cambio su denominación social, lo cual permitió la elusión del pago de los derechos antidumping provisionales aplicados por la Comisión. Al respecto, se precisa:

Que mediante Resolución $N^{\circ}$ 051-2002/CDS-INDECOPI, de fecha 09 de setiembre de 2002, la Comisión dispuso imponer una multa de diez (10) UIT a la empresa International Paper Foodservice S.A., antes "Food Pack S.A.", al haber ocultado información sobre el cambio de su denominación social con la evidente intención de evadir el pago de derechos antidumping provisionales, lo cual motiva a la Comisión a tener especial cuidado al momento de resolver la aplicación de derechos antidumping definitivos, para evitar que vuelva a ocurrir una situación similar.

Resolución 052-2002/CDS-INDECOPI

\subsubsection{CASO TEJIDOS TIPO POPELINA:}

Uno de los conflictos, sobre prácticas elusivas, que la Comisión conoció recientemente fue el Caso Tejido Tipo Popelina. Esta cuestión tiene sus antecedentes en la Resolución N 017-2004/CDS-INDECOPI, en el cual la Comisión determina la aplicación de derechos antidumping sobre las importaciones de tejidos tipo popelina, originarios de Pakistán. Posteriormente, la autoridad dispone mantener las medidas antidumping por un periodo adicional de 05 años, mediante Resolución N 031-2010/CFD- INDECOPI.

El 24 de diciembre de 2014, por solicitud de Perú Pima S.A. y mediante Resolución $\mathrm{N}^{\circ}$ 136-2014/CFD-INDECOPI, se estableció el inicio de un procedimiento de examen por expiración de medida, en el que la autoridad decidiría si extendía la vigencia de las medidas antidumping originalmente impuestas.

Posteriormente, el 18 de marzo de 2015, la empresa Perú Pima solicita el inicio de un procedimiento de examen por elusión de derechos antidumping; siendo, justamente, esta última petición la base de análisis de este acápite. 
La empresa peruana acusaba la realización de prácticas elusivas que se manifestaba mediante un cambio en los patrones de comercio adscritas a las importaciones de tejidos tipo popelina, originarios de Pakistán. El accionar elusivo consistía, según la denunciante, en la reducción de importaciones de tejidos tipo popelina y el incremento, por reemplazo, de ropa de cama, sábanas, fundas y forros.

El fundamento jurídico, que acompañó la solicitud de Perú Pima, se concentra principalmente en el artículo 58 del Decreto Supremo № 006-2003-PCM, modificado por el Decreto Supremo N 004-2009-PCM, el cuál dispone la aplicación de derechos antidumping sobre la importación de partes, piezas o componentes provenientes del país de origen del producto final sujeto a derechos definitivos, cuando existan evidencias de que tales importaciones se realizan con la finalidad de eludir la aplicación de derechos antidumping impuestos al producto final.

Sobre esa base, Perú Prima alegó que el empleo de los tejidos tipo popelina, los cuales se encuentran sujeto a medidas antidumping, como insumo para la terminación de ropa de cama es una modalidad de elusión que debe ser castigada por la autoridad administrativa, mediante la aplicación de derechos antidumping a la importación de estos últimos productos. Los fundamentos de la empresa peruana se desarrollan bajo la óptica de que los tejidos tipo popelina se constituyen como componentes en la elaboración del producto final, llámese ropa de cama. Según se resaltó, además, esta operación comercial no significó un importante trabajo de perfeccionamiento ni el desarrollo de un significativo valor agregado.

Por su parte, según se señala en la Resolución №62/CFD-INDECOPI, la Comisión basó su análisis y decisión en los siguientes fundamentos. En primer lugar, resaltó los criterios que se desprenden del artículo 58 del Reglamento Antidumping, tales como la evaluación de si el producto vendido en el Perú fue montado o terminado en el país o en un tercer país con partes, piezas o componentes producidos en el país de origen del producto final sujeto a derechos definitivos; si el proceso de montaje fue realizado por una parte vinculada al productor o exportador del producto sujeto a derechos antidumping; o, si las 
importaciones de las partes, piezas o componentes aumentaron con posterioridad a la imposición de los derechos.

Por otro lado, la autoridad reconoció que el principio de legalidad, establecido en la Ley 27444 Ley de Procedimientos Administrativos Generales, y la regla de competencia circunscrita se constituyen como la base para inhibirse de aplicar medidas sobre un supuesto no establecido expresamente en la ley, el campo atributivo adscrito a la autoridad se determina pues de acuerdo a lo establecido por la norma.

Al respecto, cabe señalar que el hecho alegado por Perú Pima referido a la importación de un producto final elaborado a partir de un componente (tejido tipo popelina) sujeto a la aplicación de derechos antidumping, no se encuentra regulado como supuesto de elusión en el artículo 58 del Reglamento Antidumping, el cual contempla de forma específica la modalidad de elusión consistente en la importación de partes, piezas o componentes de un producto final afecto a derechos antidumping, el cual es posteriormente montado, ensamblado o terminado para su comercialización en el territorio nacional.

Resolución Nº62-2015/CFD-INDECOPI

Como se observa, la autoridad administrativa se inhibió de aplicar medidas antidumping sobre la importación del producto pakistaní ropa de cama, por no considerarse que la práctica denunciada por la empresa peruana encaje en el supuesto de hecho elusivo establecido en el artículo 58 del Reglamento Antidumping.

Como se observa, los hechos descritos por la empresa peruana encajarían en otra fórmula elusiva, la cual es conocida también como "el método inverso de la elusión tradicional" o downstream circumvention por su terminología en inglés. Esta fórmula explica que el producto, al cual se le han aplicado medidas antidumping, sería empleado para incorporarlo dentro de otro producto. La esencia de este supuesto consiste en someter el insumo a un proceso que no implica mayor perfeccionamiento o inclusión de un importante valor agregado, pero es una práctica suficiente para variar las condiciones de comercio, evitando así el pago de las medidas antidumping. 
Si proyectamos la explicación antes reseñada al caso propuesto, podríamos indicar que el tejido tipo popelina ha sido empleado como insumo para incluirlo en otro producto terminado: ropa de cama, sábanas, fundas y forros; los que ingresarán al territorio nacional con otra partida arancelaria y eludiendo el pago de los derechos antidumping.

Pero, independientemente del tipo elusivo que más se ajuste a las condiciones de hecho propuestas en el caso, lo cierto es que nuestra única disposición antielusiva es muy limitada y no cubre otras fórmulas de elusión, lo que, sin lugar a dudas, inhibe a la autoridad en su quehacer dirigido a la supresión de distorsiones en el comercio.

\subsection{FUNDAMENTOS PARA LA MODIFICACIÓN DEL REGLAMENTO ANTIDUMPING PERUANO}

Existen principios que constituyen la base del sistema multilateral de comercio y son el fundamento del quehacer de la OMC (1995), tales como:

Ser más abierto: la disminución de los obstáculos comerciales es una de las formas más evidentes de fomentar el comercio; esos obstáculos pueden consistir en derechos de aduana (o aranceles) o en medidas como la prohibición de las importaciones o la fijación de contingentes que restringen selectivamente las cantidades.

Ciertamente, la apertura comercial, a través de la eliminación de barreras arancelarias, ha generado beneficios a nivel mundial, pero se consideró menester, además, plantear reglas y diseñar un sistema que permita competir en el mercado internacional, bajo condiciones idóneas y eliminando conductas desleales:

Ser más competitivo: desalentar, para ello, las prácticas "desleales", como las subvenciones a la exportación y el dumping de productos a precios inferiores a su costo para obtener una mayor participación en el mercado. Las cuestiones son complejas, y las normas tratan de establecer lo que es leal o desleal y la manera en 
que los gobiernos pueden responder, especialmente imponiendo derechos de importación adicionales calculados para compensar los perjuicios causados por el comercio desleal.

(OMC, 1995)

La esencia de los acuerdos suscritos bajo el marco de la OMC es el libre comercio, sin embargo, los agentes que participan en el comercio internacional deben conducirse bajo criterios competitivos, evitando ejecutar prácticas dumping que dañen la industria domestica del país importador. Mas los exportadores y productores extranjeros han encontrado la forma de burlar los efectos correctores asignados a los derechos antidumping. Sin lugar a dudas, esta conducta elusiva contrasta con los principios perseguidos por la OMC y sus miembros. Resulta lógico que al verse mermado el sistema antidumping, se proyecten medidas que ratifiquen los objetivos perseguidos por los derechos antidumping; lo que la presente tesis propone es la aplicación de medidas antielusivas.

Lo ideal es que la OMC procure una negociación entre los países miembros que desemboque en un acuerdo internacional igualmente aplicable a todos los actores comerciales, sin embargo, aunque el tema ha sido calificado como una problemática latente, no se ha arribado a una resolución capaz de satisfacer al conjunto de países. Al respecto, importa traer a colación la Decisión sobre Medidas contra Elusión de los Acuerdos de la Ronda de Uruguay, el cual suscribe:

Tomando nota de que, aun cuando el problema de la elusión de los derechos antidumping ha sido uno de los temas tratados en las negociaciones que han precedido al Acuerdo relativo a la Aplicación del Artículo VI del GATT de 1994, los negociadores no han podido llegar a un acuerdo sobre un texto concreto. Conscientes de la conveniencia de que puedan aplicarse normas uniformes en esta esfera lo más pronto posible, deciden remitir la cuestión, para su resolución, al Comité de Prácticas Antidumping establecido en virtud de dicho Acuerdo.

(OMC , 1994, pág. 425) 
Dadas las circunstancias, y teniendo en cuenta que las reglas del Acuerdo Antidumping y del Artículo VI del GATT no prohíben explícitamente la aplicación de medidas antielusivas, se pretende modificar nuestro Reglamento Antidumping e incluir una regulación en contra de las prácticas elusivas que anulen los efectos correctores de los derechos antidumping, en detrimento de las industrias domésticas. Importa precisar que nuestra propuesta no busca avalar u otorgar bases proteccionistas, sino que más bien plantea la modificación de nuestra normativa antidumping, mediante la inclusión de medidas antielusivas las cuales van a procurar una competencia leal que repotencie la eficiencia en las exportaciones e importaciones. A continuación, se expondrán ciertos criterios bajo los que sustenta nuestra posición.

\subsubsection{CONFORMIDAD DE LAS MEDIDAS ANTIELUSIVAS RESPECTO A LA NORMATIVA INTERNACIONAL ANTIDUMPING:}

Legalmente hablando, se señala que el artículo 18.1, 18.2 y el pie de página 24 del Acuerdo Antidumping son los dispositivos que sustentan la falta de correspondencia entre las medidas antielusivas y las reglas del Acuerdo Antidumping. Dichos numerales señalan lo siguiente:

Artículo 18.1: No podrá adoptarse ninguna medida específica contra el dumping de las exportaciones de otro Miembro si no es de conformidad con las disposiciones del GATT de 1994, según se interpretan en el presente Acuerdo.

Artículo 18.2: No podrán formularse reservas respecto de ninguna de las disposiciones del presente Acuerdo sin el consentimiento de los demás Miembros.

Pie de página 24: Esta cláusula no pretende excluir la adopción de medidas al amparo de otras disposiciones pertinentes del GATT de 1994, según proceda.

(Acuerdo General sobre aranceles aduaneros y Comercio)

Para demostrar que las medidas antielusivas no son incompatibles con el Acuerdo Antidumping, se deberá establecer que aquellas no son medidas específicas en contra el dumping o, en caso se determine su calidad de medidas específicas contra el dumping, 
podrán seguir siendo legítimas, mientras las medidas antielusivas se encuentran en conformidad con las disposiciones pertinentes del GATT de 1994.

Según Yanning Yu (2008), la proposición “medida específica contra el dumping” puede ser entendida en dos niveles. Por un lado, se puede referir a una medida que abarca acciones tomadas cuando se presenten los elementos que constituyen el dumping. O pueden concebirse como medidas que son compatibles con el propósito "contra el dumping" en vez de perseguir otros objetivos. (pág. 198)

Para empezar, importa insistir en el hecho de que no existe dispositivo prohibitivo alguno que impida la aplicación de medidas antielusivas, por tanto, podría decirse que, desde un somero análisis, aquellas podrían ser consideradas como medidas legítimas. Recordemos además que cuando el Panel del GATT tuvo la oportunidad de manifestarse sobre la legitimidad de las medidas en cuestión, en el Caso Unión Europea vs. Japón, ésta decantó por inhibirse de realizar cualquier pronunciamiento, por tanto, no existe un Reporte del GATT/OMC que exprese manifiestamente la inconsistencia de las medidas antielusivas con las reglas del Acuerdo Antidumping y del Artículo VI del GATT. Sin embargo, resulta conveniente profundizar en la investigación y hacer específica referencia al Artículo 18.1 del Acuerdo Antidumping.

Se debe entender que las prácticas dumping y las elusivas encierran condiciones disímiles, consecuentemente, los derechos antidumping y las medidas antielusivas persiguen objetivos opuestos. Por la celeridad que requieren los procedimientos antielusivos, las legislaciones comparadas no solicitan la configuración de los mismos elementos que conforman el dumping, ni el conjunto de criterios establecidos para las investigaciones antidumping. Por un lado, los derechos antidumping tienen el propósito de repeler las prácticas desleales de discriminación internacional de precios que genera un daño a la industria doméstica del país importador; mientras que las medidas antielusivas combaten la elusión, es decir, la práctica específica de evitar el pago de los derechos antidumping anteriormente impuestos. Como bien señala Yanning Yu (2008), "la expresión "en contra del dumping” es aparentemente diferente de la expresión “en contra de la elusión” (pg. 199). Por todo lo antes expuesto, puede concluirse que la medida antielusiva no debería ser 
considerada como "medida específica contra el dumping" y, consecuentemente, no se violaría los establecido por el Artículo 18 del Acuerdo Antidumping.

\subsubsection{INCREMENTO DE PRÁCTICAS ELUSIVAS EN UN CONTEXTO DE VACÍO LEGAL:}

Por otro lado, y como ya se estableció anteriormente, existe casuística a nivel internacional y nacional que demuestra el efectivo ejercicio de prácticas elusivas en el comercio internacional. Ello proyecta una falencia en nuestra normativa, por existir un vacío legal incapaz de hacer frente al problema elusivo, por ello, resulta menester preparar nuestro sistema para este tipo de contingencias. A modo de ejemplo, recordemos que, por circunstancias de desgravación, para el 2026 ingresará el 100\% de productos originarios de China sin pagar aranceles, lo que podría significar el incremento de conductas desleales. Por tanto, nuestro Reglamento Antidumping debe estar preparado para enfrentar la problemática que enfrenta nuestra coyuntura comercial: las prácticas elusivas. Caso contrario existirá un vacío legal en nuestra legislación que permitiría un accionar desleal por parte de exportadores y productores extranjeros lo que provocaría que se arrase fácilmente con nuestras incipientes industrias nacionales.

\subsubsection{Medidas antielusivas, La COMPETENCIA Y LAS VENTAJaS COMPARATIVAS:}

La corriente que se manifiesta en contra de las medidas antielusivas señala que el único objetivo que persiguen los países que se encuentran a favor de ellas es limitar la competencia en el mercado internacional y ello, según señalan, responde a una falta de capacidad y ventaja comparativa. Sustentan, además, que las barreras no arancelarías son dañinas, por distorsionar la eficiencia en la producción y la participación en el mercado, eliminando sus ventajas comparativas que son la base de su eficiencia.

Existen muchos elementos que van a definir el grado de ventaja comparativa que un país tenga sobre el otro, tales como la educación, la tecnología, la productividad, la 
calidad de mano de obra, el perfeccionamiento en la producción, entre otros; sin embargo, existen además factores exógenos que inciden en la ventaja comparativa de un país en el marco del comercio internacional, hacemos referencia a las políticas comerciales y a los diversos sistemas legales y económicos.

Si bien la teoría de las ventajas comparativas se engendra para explicar el nacimiento y desarrollo del comercio internacional, en la práctica deberán tenerse en cuenta otros factores que, del mismo modo, inciden en el mercado y la competencia que en ella se da. Las barreras paraarancelarias, como los derechos antidumping y las medidas antielusivas, propuestas en la presente tesis, son instrumentos que forman parte del sistema legal diseñado para el comercio internacional. Por tanto, si no se toman en cuenta ni se reconoce la existencia de factores exógenos que inciden en el mercado y en sus agentes, entonces aquella teoría resultaría insuficiente. Bajo esta óptica, resulta inviable afirmar que el objetivo principal de la aplicación de medidas antidumping o antielusivas sea la de obstaculizar la eficiencia en el comercio y la de anular sus ventajas comparativas, pues el único, real y legítimo propósito es la eliminación de distorsiones en el mercado que se generan en razón de conductas desleales que buscan menoscabar el desempeño de las industrias en el país importador.

Los bienes que normalmente son materia de intercambio en el mercado mundial se constituyen en productos tradicionales ${ }^{42}$ y productos no tradicionales ${ }^{43}$. Los productos primarios representan un porcentaje muy alto del valor total de las exportaciones peruanas sobre las exportaciones no tradicionales. Podemos considerar que las materias primas constituyen los productos bandera en la comercialización peruana, pues tienen en su haber una larga tradición exportadora. Por otro lado, los productos no tradicionales forman parte de nuestras exportaciones a menor escala; si bien es cierto que el índice de ventas de los

\footnotetext{
42 También son conocidos como productos primarios, productos básicos, materias primas o commodities. Según señala el Decreto Supremo $N^{\circ}$ 076-92-EF, dispositivo legal que dispone la lista de productos de exportación tradicional, los bienes que comprende este grupo se centra principalmente en productos agropecuarios, productos pesqueros, productos mineros, petróleo y sus derivados.

43 Los productos no tradicionales, también conocido como mercancías manufacturadas, son agrupadas según el BCR en productos agropecuarios, textiles, maderas y papeles, químicos, metal-mecánicos, siderometalúrgicos y joyería, minera no metálica, entre otros.
} 
productos manufacturados ha aumentado en los últimos años, ello no ha sido suficiente para superar los resultados proyectados por las exportaciones de materia prima. Ciertamente, se podría concluir que las ventajas comparativas de nuestro país se concentran principalmente en los productos tradicionales. Mientras que otros países, pobres en recursos naturales, han condicionado su ventaja comparativa en torno a la tecnología y el desarrollo de productos manufacturados. Tal es el caso del país de China, cuya ventaja comparativa se reduce en la exportación de productos no tradicionales. Como bien se señala:

Podría darse el caso de un país latinoamericano que tenga una ventaja comparativa en la producción de bienes en los que es relativamente más eficiente y viceversa, en tanto que un país industrializado hallará razonable especializarse en aquellas mercancías en que su ventaja absoluta es relativamente mayor y, a su vez, comprar en el país subdesarrollado, que posee la mayor desventaja absoluta.

(Sierralta Ríos, 2007, pág. 53)

El comercio ha sido usado como una herramienta que permite a los países repotenciar sus ventajas comparativas frente al mundo; ello ha permitido, innegablemente, el progreso económico tanto de países desarrollados como la de los no desarrollados, sin embargo, no es menos cierto que existe aún una relación asimétrica ente aquellos. Si bien hemos sido testigos del surgimiento de países emergentes ${ }^{44}$, la brecha entre países pobres e industrializados se mantiene. Bajo estas condiciones, consideremos además que los países industrializados incurren en prácticas comerciales desleales que naturalmente serán contraproducentes para los países cuya brecha, en la economía mundial, no favorece.

Es claro que la intención de los productores y exportadores extranjeros al ejecutar acciones elusivas no es el de competir o repotenciar sus ventajas comparativas, sino "sacar la vuelta" a los acuerdos establecidos y a las reglas comprendidas en el sistema antidumping. Si analizamos las posiciones en contra de las medidas antielusivas, notaremos que el ropaje bajo el que ocultan su accionar desleal, proyectado mediante prácticas elusivas, son conceptos como el libre comercio, la ventaja comparativa y las estrategias

44 Ejemplos de mercados emergentes son los BRICS (el cual comprende a Brasil, Rusia, India, China y Sudáfrica) y los MIST (el cual comprende a México, Indonesia, Corea del Sur y Turquía). 
comerciales. Ciertamente, aquellos agentes se amparan en principios que inspiran la labor de la OMC y sus miembros para competir en el mercado, pero en condiciones desleales.

\subsubsection{LA TEORÍA DEL DILEMA DEL PRISIONERO:}

Otro de los criterios que refuerza la conveniencia de normar en contra de las prácticas elusivas es la aplicación de la Teoría del Dilema del Prisionero. Si aterrizamos las reglas de dicha teoría bajo el contexto del comercio internacional, tendríamos la concurrencia de dos países, los cuales detentan sus propias ventajas comparativas y persiguen sus respectivos intereses sociales, comerciales y económicos. Supongamos que, por un lado, el país A regula de forma incipiente las prácticas desleales realizadas entre agentes internacionales, lo que, de alguna manera, avala las conductas dumping y elusivas en el marco del comercio internacional. Por otro lado, el país B busca proteger sus industrias domésticas de los efectos negativos generados por el accionar desleal de los operadores comerciales del país A, mediante una reglamentación en extremo proteccionista que funge de barrera en contra del libre comercio. El conflicto existente refleja la colisión entre dos corrientes que buscan saciar sus propios intereses de acuerdo a sus condiciones y ventajas. Las consecuencias lógicas de estos procederes será que un país se vea beneficiado frente al detrimento del otro o que ambas conductas egoístas, en vez de coadyuvar a la eficiencia social y comercial, menoscaben el sistema antidumping diseñado por la OMC. Lo que se espera es alcanzar un punto de equilibrio entre los intereses de ambos país, lo que impulsará un accionar en pro del bien común. Si bien la cooperación amistosa implica un costo real para cada país, los resultados que ésta generará para las partes serán más óptimos y beneficiosos.

La cooperación conjunta, en referencia a las prácticas de elusión, puede proyectarse de dos maneras. Una de ellas es que los países en contra de la aplicación de medidas antielusivas reconozcan que la elusión se constituye como una problemática que ya forma parte de la coyuntura del comercio internacional y que los países favor de dicha medida manifiesten una actitud conciliadora y menos proteccionista, ello va a permitir que, bajo el marco de la OMC, se negocie y se arribe a un compromiso común. Un acuerdo 
internacional, que establezca directrices y criterios que se apliquen de forma colectiva a los países miembros de la OMC, sería el instrumento idóneo para combatir este comportamiento desleal, en contraste con la desventura que significa la emisión disgregada en diversos países de sus reglamentaciones antielusivas. Mas ante la falta de un pronunciamiento oficial por parte de la OMC, otra manera de cooperación se expresa mediante el compromiso de los países en ser consecuentes respecto a sus conductas comerciales. Una normativa antielusiva no tiene como objetivo ir en contra de la libre competencia, sino que más bien repele la competencia con atisbos desleales. Por tanto, una parte está llamada a ajustar su accionar, de tal manera que se procure la libre competencia sin la necesidad de incurrir en actos desleales, tales como las prácticas dumping y elusivas, y la otra, a regular en contra de las conductas antielusivas de acuerdo a los parámetros establecidos por los Acuerdos Internacionales existentes, evitando incurrir en un trato proteccionista.

De cualquier forma, el objetivo que plantea la Teoría del Dilema del Prisionero consiste en ser conscientes de los beneficios que implica para el sistema antidumping la cooperación común entre países, en contraposición con las dificultades que significaría que cada país actúe de acuerdo a sus propios intereses. Importa tener en cuenta esta apreciación para que se fomente un bienestar común entre los exportadores, productores, importadores y consumidores.

\subsection{ProyeCto de MOdifiCACión del REglamento ANTIDUMPING PERUANo}

El pasado 2011, la Comisión de Dumping, Subsidios y Eliminación de Barreras no Arancelarias presentó un Proyecto de Modificación del Decreto Supremo $N^{\circ}$ 006-2003PCM para incorporar disposiciones que permitan enfrentar las prácticas de elusión de derechos antidumping. El documento que contiene la Exposición de Motivos hace referencia a los siguientes rubros: 
- Primero, se expone un acápite introductorio en el que se explica cómo el aumento en la aplicación de los derechos antidumping determinó la ejecución de prácticas de elusión que evitan el pago de dichas medidas, fenómeno que se constituye como una problemática en nuestro comercio internacional.

- Posteriormente, se desarrollan los fundamentos que sustentan su propuesta, para tal fin, se explican las disposiciones que componen la legislación comparada en contra de las prácticas elusivas.

- Seguidamente, se listan las propuestas de reforma y modificación del artículo 58 (mediante la inclusión del artículo del Artículo 58-A, que contiene los alcances y modalidades de la práctica elusiva, y el Artículo 58-B, que comprende las disposiciones procedimentales), del artículo 33 y del artículo 57 del Reglamento Antidumping Peruano.

- Finalmente, se realiza un análisis costo - beneficio respecto a la modificación antes descrita.

Para el mejor desarrollo de la presente investigación, pasaremos a hacer específica referencia al acápite de Propuestas de Reforma y Modificación, realizando comentarios y recomendaciones al respecto.

En primera instancia, se establece la importancia de insertar otras modalidades elusivas que se han ido desarrollando frecuentemente en el mercado internacional, para ello, se enumeran seis modalidades específicas de elusión y, finalmente, se concluye con una cláusula general, la cual será aplicada en situaciones no previstas expresamente.

\subsubsection{PRIMERA FóRMUla ElUSIVA:}

Se contempla como una conducta de elusión de las medidas antidumping aplicadas por la autoridad administrativa a: 
La importación de insumos, piezas, partes o componentes de un producto sujeto a derechos antidumping con el objeto de producir, ensamblar o acabar el producto en el Perú. En este caso se verificará que:

(i) Los insumos, piezas, partes o componentes proceden del país o territorio aduanero sujeto a derechos antidumping.

(ii) Los insumos, piezas, partes o componentes son utilizados para producir, ensamblar o acabar un producto que tiene las mismas características físicas $\mathrm{y}$ usos que el producto sujeto a derechos antidumping.

(iii) El proceso de producción, ensamblaje o acabado realizado en el Perú es menor o insignificante; $y$,

(iv) Los insumos, piezas, partes o componentes importados tienen un valor significativo respecto del valor total del producto final.

(INDECOPI, 2011, pág.20)

Como podrá notarse, este supuesto elusivo se encuentra actualmente incluido en el Reglamento Antidumping, sin embargo, el pequeño, pero importante cambio introducido en la propuesta radica en la inclusión de los insumos en la ecuación normativa.

Esta modificación fue aplaudida por grupos como la Corporación de Cuero, Calzado y afines, así como por la Sociedad Nacional de Industrias, la cual precisó que resulta acertada la incorporación de la importación de insumos como uno de los supuestos de elusión, pues en algunas industrias el insumo se convierte en producto terminado luego de una proceso muy sencillo, además puntualiza que:

Este criterio, el de importación de insumos, piezas, partes o componentes (...) son supuestos que el acuerdo de origen de la OMC reconoce como el criterio de la operación de fabricación o elaboración, según el cual no cualquier proceso de fabricación o elaboración por si solo es suficiente para conferir origen.

(Comunicación personal, 5 de abril de 2016) 
Por otro lado, esta propuesta fue criticada por la Sociedad de Comercio Exterior del Perú (COMEX) y por empresas privadas como COLORTEX Perú, las cuales consideran que la extensión en la aplicación de derechos antidumping en supuestos de producción de insumos es excesiva y riesgosa. COLORTEX precisa que:

Ello se puede convertir en una herramienta que use la industria textil para afectar las importaciones de TODO TIPO de telas o hilados. Todos los insumos se importan con el fin de producir y es preocupante que el simple hecho de importar hilados te convierta en sospechoso de elusión.

(Comunicación personal, 5 de abril de 2016)

Al respecto, consideramos que la inclusión de insumos en la fórmula elusiva es legítima, sin embargo, es necesario que la disposición sea lo más clara posible. Existen términos amplios que dejarían a discreción de la autoridad administrativa su interpretación. Por tanto, creemos conveniente el desarrollo expreso de diversos criterios que ayuden a los agentes comerciales, que participen en la investigación, a entender qué será considerado como conducta elusiva y qué elementos serán tomados en cuenta por la autoridad para realizar conclusiones.

En primera instancia, de acuerdo a lo señalado en el numeral i, podría entenderse que la intención de la Comisión fue cubrir el control de prácticas elusivas adscritas a importaciones realizadas por agentes comerciales desde países extranjeros, en su condición de territorios nacionales, y territorios aduaneros de terceros países. Cabe recordar que no siempre la delimitación geográfica de un territorio nacional coincide con la del territorio aduanero, pues es posible que, como en el caso de la Comunidad Europea, el mismo régimen arancelario y aduanero sea aplicado en diferentes países. Por ello, consideramos que es válido considerar esta diferenciación y resulta conveniente cubrir la importación tanto de países extranjeros y territorios aduaneros.

Por otro lado, el numeral ii se limita a considerar solo las características físicas y de uso existentes entre el producto producido, ensamblado o acabado y el producto sujeto a medidas antidumping. Sería conveniente considerar además otros elementos, tales como el 
nivel de desarrollo tecnológico, el público objetivo que comprende el mercado de uno y otro producto, entre otros.

Un criterio adicional que podrá ser tomado en cuenta por la autoridad administrativa, para evidenciar una práctica elusiva, es el momento en el que se ejecuta la producción, el ensamblado o el acabado. Podría considerarse como válido el recurrir a factores económicos razonables, tales como procurar una nueva locación geográfica para la producción, mas esta relocalización resultaría cuestionable y sospechosa cuando es realizada durante el curso de una investigación antidumping o justo después de que se hayan determinado la aplicación de los derechos antidumping.

Ahora bien, respecto al numeral iii, acusamos que la expresión un proceso de producción, ensamblaje o acabado "menor o insignificante" promueve la ambigüedad de la disposición. Lo óptimo es que propuestas como éstas sean lo más concretas posibles, ello va a coadyuvar a que se establezcan los parámetros anticipadamente, generando predictibilidad en las resoluciones de la autoridad administrativa. Creemos que para aclarar dichos términos, la Comisión podría considerar criterios como el nivel de inversión y de investigación realizados en nuestro país; la naturaleza del proceso de producción, ensamblaje o acabado; el carácter de las instalaciones y mobiliarios; la especialidad en el recurso humano laboral; y, si cabe, el desarrollo de valor agregado al producto final.

Con el fin de aterrizar dichos criterios en un ejemplo, importa citar el caso que fue presentado por INDECOPI (2011): La autoridad mexicana había dispuesto la aplicación de derechos antidumping al producto denominado "cobertores estampados", originarios de China, sin embargo, tiempo después, se evidenció la sustitución de dichos productos por los rollos de tela tejido de punto de pelo largo tipo raschel estampado, provenientes del mismo país; se creía, pues, que éste último producto era empleado para la elaboración de los cobertores estampados. El accionar de los exportadores chinos justificó el inicio de una investigación por la posible ejecución de prácticas elusivas, el cual finalizó con las siguientes conclusiones. Primero, se determinó que en México se sometían los rollos de tela a operaciones relativamente simples y de poco valor agregado. Además, el proceso no implicaba la realización de una gran inversión, la utilización de maquinarias ni la 
contratación de mano de obra especializada. Finalmente, se expuso que no existía una razón económica que justificase dicha actividad. La ejecución de un proceso de producción menor, realizado en el país importador, permitió exponer la existencia de una conducta elusiva, lo que permitió disponer la extensión de las medidas antidumping a los rollos de tela. (pág. 20)

Como se observa, la autoridad puede valerse de ciertos criterios para realizar conclusiones, sin embargo, lo ideal es que dichos elementos de juicios sean incluidos expresamente en la norma.

En base a la recomendación estipulada en el párrafo anterior, advertimos que la misma lógica puede ser aplicada en el numeral iv el cual no establece qué se entiende por "valor significativo". Una forma de limitar el criterio de la Comisión respecto a lo que se pueda entender por "valor significativo" es cuantificando este criterio. Al igual que la legislación europea podría plantearse que los insumos partes, piezas o componentes constituyan el $60 \%$ o más del valor total de las partes del producto montado, sin embargo, puede otorgarse una prerrogativa al exportador extranjero consistente en considerar como una práctica comercial legítima, no calificada como elusión, al implemento de un valor añadido conjunto de las partes utilizadas durante la operación de montaje que sea superior al $25 \%$ del coste de producción. Los porcentajes señalados pueden ser reformulados por la Comisión, mas es preferible cuantificar los términos en vez de usar formulas amplias y discrecionales.

Con el fin de evidenciar la diferencia que implica circunscribir y definir lo más específicamente posible los criterios usados por la autoridad, citaremos el ejemplo desarrollado por COLORTEX:

Si se aplica un derecho antidumping a las importaciones de motores de China es lógico que si se comienzan a importar las piezas de dichos motores podrían haber una supuesta práctica de elusión pero las piezas de los motores también tienen sus propias piezas y éstas últimas están hechos por ejemplo de acero y podría darse el caso que INDECOPI con este cambio al Artículo 58 pueda aplicar los derechos a la 
importación de acero porque algún fabricante nacional de motores denuncia que en lugar de motores ahora se importan partes de piezas o materia prima.

(Comunicación personal, 5 de abril de 2016)

Teniendo en cuenta que la propuesta comprende términos ambiguos, es hasta comprensible la preocupación de COLORTEX en torno al alcance que podrían tener las medidas antielusivas, creyendo éstas que se puede fácilmente cuestionar la importación incluso de materias primas.

Consideramos que resultaría improbable la aplicación de medidas antielusivas en el caso propuesto, pues, aplicando el criterio del numeral iii, el proceso de producción necesario para transformar el acero en piezas de un motor y ensamblarlas posteriormente para montar el producto final en Perú, implicaría usar maquinaria, mano de obra especializada y la propia naturaleza de producción es tal que difícilmente podría ser calificado de menor o insignificante. Sin embargo, no podría arribarse a dicha conclusión si no se tienen claros los criterios que serán tomados en cuenta en los numerales de cada supuesto. El plantear un proyecto de modificación implica ser muy minucioso, pues un mal enfoque puede generar legítimas preocupaciones en los agentes comerciales.

\subsubsection{SEGUNDA FóRMULA ELUSIVA:}

El segundo supuesto de elusión que establece el Proyecto de Modificación del Reglamento Antidumping consiste en:

"La importación de un producto que haya sido producido, ensamblado o acabado

en un tercer país o territorio aduanero con insumos, piezas, partes o componentes originarios del país o territorio aduanero sujeto a derechos antidumping. En este caso se verificará que: 
(i) El producto producido, ensamblado o acabado en el tercer país o territorio aduanero tiene las mismas características físicas y usos que el producto sujeto a derechos antidumping.

(ii) El proceso de producción, ensamblaje o acabado realizado en el tercer país o territorio aduanero es menor o insignificante; $y$,

(iii) Los insumos, piezas, partes o componentes originarios del país o territorio aduanero sujeto a derechos antidumping tienen un valor significativo respecto del valor total del producto producido, ensamblado o acabado en el tercer país o territorio aduanero".

(INDECOPI, 2011, pág.20)

En este caso, en relación a la terminología ambigua que comprenden las disposiciones, pueden adoptarse los mismos criterios interpretativos que en el supuesto elusivo anterior; asimismo, podemos puntualizar las siguientes recomendaciones:

El inciso primero hace evidente referencia a la extensión de los derechos antidumping al "producto similar" que es usado para ejecutar la práctica elusiva. El numeral 2.6 del Acuerdo Antidumping ha definido lo que deberá entenderse por "producto similar":

En todo el presente Acuerdo se entenderá que la expresión "producto similar" ("like product") significa un producto que sea idéntico, es decir, igual en todos los aspectos al producto de que se trate, o, cuando no exista ese producto, otro producto que, aunque no sea igual en todos los aspectos, tenga características muy parecidas a las del producto considerado.

Como se podrá advertir, son dos los criterios tomados en cuenta para considerar a una mercancía como producto similar: semejanza física y semejanza en el uso. Aquella definición resulta, hasta cierto punto, incompleta, por lo que, si bien éstas son las únicas condiciones establecidas por el Acuerdo Antidumping, resultaría conveniente que la autoridad tome en consideración otros elementos que permitan delimitar de una mejor manera al producto similar. En tal sentido, Yanning Yu (2008) recomienda: 
(...) son diversos factores empleados para tenerlos en cuenta al determinar si un producto debe ser considerado como producto similar de otro. Aquellos factores deberían incluir, por ejemplo, la identidad física, el grado de desarrollo tecnológico, el grado de sustitución, si hay un mismo mercado competitivo entre aquellos productos y si el producto comparte algunas características esenciales de origen. Además, si se consideran todos los factores arriba mencionados, éstos deberán ser tomados como uno solo, evitando que algún factor juegue un rol dominante. (pág. 206)

Esta sugerencia resulta ventajosa, pues la determinación del producto similar es una de las etapas más importantes dentro del procedimiento antielusivo, por lo que, es conveniente que se tomen en cuenta un conjunto de criterios para hacer dicha delimitación más precisa.

Otra de las cuestiones que salta, en razón de este supuesto, es la diferenciación entre el país de exportación y el país de origen. En esta ocasión un tercer país juega un rol dentro de la operación comercial, sin embargo, su participación se resume a la simple exportación de un producto que no sufrió mayor procesamiento. Las partes, piezas, componentes o insumos son producidos en el país al cual se le aplicaron los derechos antidumping; aquellos son exportados a un tercer país en donde se realiza un nimio procesamiento, ensamblado o acabado. Una vez más, para realizar dicha determinación, la autoridad deberá tener en cuenta factores como el nivel de inversión, de investigación y desarrollo, el nivel del proceso de producción y la extensión de sus instalaciones en el país de exportación. Además, se verificará el valor que representan las piezas, partes, componentes o insumos respecto al valor total del producto similar. $\mathrm{Si}$, una vez culminado el proceso antielusivo, la autoridad concluye en la convergencia de criterios que respalden la existencia de un supuesto elusivo, la autoridad extenderá la aplicación de los derechos antidumping asignados al país de origen, al producto producido, ensamblado o acabado en el tercer país, el cual hace sus veces de país exportador.

Claramente, ello despierta el debate sobre otro tema y es ¿cómo establecer el verdadero origen de las partes, piezas, componentes o insumos que son empleados para 
conformar el producto final, materia de la investigación? Para responder este cuestionamiento, podemos remitirnos al Acuerdo sobre Normas de Origen, cuyo Artículo 1.2 de la Parte I señala que:

Las normas de origen a que se refiere el párrafo 1 comprenderán todas las normas de origen utilizadas en instrumentos de política comercial no preferenciales, tales como en la aplicación: (...) de los derechos antidumping y de los derechos compensatorios establecidos al amparo del artículo VI del Página 226 GATT de 1994. (el subrayado es nuestro)

Es decir, las normas de origen pueden regular situaciones de trato arancelario preferencial, pero también aspectos de política comercial no preferencial como es el caso del Decreto Supremo N 005-2011-MINCETUR, que establece el marco normativo para la declaración y control del origen de las mercancías sujetas a medidas de defensa comercial.

Con el propósito de cubrir la conducta elusiva, el agente del tercer país declarará como originario el producto objeto de exportación, sin embargo, deben recordarse dos premisas: primero, las partes, piezas, componentes o insumos son originales del país al cual se le aplicó originalmente los derechos antidumping y aquellos solo fueron enviados al país de exportación para la realización de un nimio ensamblado o acabado; segundo, la sola operación de acabado no confiere origen. Ahora bien, según el dispositivo legal antes citado, la autoridad, que en este caso se concentra en el funcionario de la Superintendencia Nacional de Administración Tributaria SUNAT, podrá exigir, del importador de la mercancía que podría estar sujeta a medidas de defensa comercial, una Declaración de Origen, en el que, entre otros datos, se reporte el nombre o razón social del productor o productores, país de producción y la dirección de la planta de producción. Asimismo, en caso concurran los indicadores de riego contenidos en el artículo 6 del mismo dispositivo legal $^{45}$, la autoridad podrá solicitar cualquier documento o información que pudiera ser

$45 \quad$ Artículo 6 del D.S. N 005-2011-MINCETUR.- Indicadores de riesgo

Se considera que existe un indicador de riesgo cuando:

a) El valor declarado de la mercancía es menor que el valor normal más alto establecido en las Resoluciones del órgano competente del Instituto Nacional de Defensa de la Competencia y de la Protección de la Propiedad Intelectual (INDECOPI), aplicables a la mercancía. 
relevante para determinar el origen de la mercancía dentro de un Procedimiento de Verificación de Origen.

Ahora bien, la labor de verificación de origen puede resultar más fácil en los supuestos de mercancías sujetas a medidas de defensa comercial, tal como los derechos antidumping, sin embargo, cuando se trata ejecutar el mismo quehacer, respecto a este supuesto de elusión, podría tornarse más complicado investigar el origen de cada parte, pieza, componente o insumo; por lo que, resulta conveniente que el importador certifique que aquellos son originarios del país exportador y no son producidos, ensamblados o acabados en un producto similar a la mercancía que fue originalmente materia de una investigación antidumping que culminó con la aplicación de medidas antidumping. Mientras que SUNAT ejercerá su función de control y fiscalización de origen no preferencial de las mercancías importadas, mediante procedimientos de verificación, La Comisión de Dumping, Subsidios y Eliminación de Barreras no Arancelarias podrá recurrir a otros criterios para evidenciar la práctica de elusión, tales como analizar la posible afiliación entre el productor o exportador de las partes, piezas, componentes o insumos del país de origen y la persona encargada de ensamblar o completar la mercancía en el tercer país para luego exportarla al mercado peruano; asimismo, se podrá verificar el incremento de las exportaciones de las partes y componentes, desde el país de origen al de exportación por causa de la iniciación del procedimiento antidumping o la decisión de aplicación de derechos antidumping; ello como bien se estipula en la legislación norteamericana.

\subsubsection{TERCERA FÓRMULA ELUSIVA:}

La importación del producto sujeto a derechos antidumping sin que se haya acreditado conforme a la normativa de la materia, que dicho producto tiene un

b) La mercancía no presenta signos ni elementos que permitan identificar el país de origen.

c) La descripción arancelaria de la mercancía es susceptible de ser utilizada para evitar el pago de una medida de defensa comercial.

d) La mercancía procede de una zona franca o de un país distinto al país de origen declarado.

e) El importador ha sido sancionado con resolución firme o consentida por declarar incorrectamente el origen de la mercancía, dentro de los dos (2) años anteriores al momento de la evaluación.

f) La información relativa al origen declarado de la mercancía no es consistente no guarda relación con la información con la que cuenta la Autoridad Aduanera.

g) El importador es una persona jurídica con una antigüedad menor a un (1) año de constitución o el importador no ha realizado al menos una importación en los últimos doce (12). 
origen distinto al del país o territorio aduanero de las importaciones afectas a derechos.

(INDECOPI, 2011, pág.21)

Para poder explicar esta disposición conviene recordar que la noción de origen difiere del de procedencia. Para clarificar el contenido de cada término presentamos la exposición realizada al respecto por PROMPERÚ (s.f.):

Procedencia: Los productos provienen del Estado o país en el cual se ha iniciado su último transporte, sin que necesaria o forzosamente sea originario del mismo. Por lo tanto, es considerado como el trayecto del país de expedición al país de destino. La procedencia de los productos es generalmente considerada para efectos de orden sanitario o fitosanitario.

Origen: Es el vínculo geográfico que une una mercancía a un determinado país, en el cual se considera que ha sido generada. Se dice que el producto es originario del país donde ha sufrido la última transformación sustancial.

Para poder corresponder con las estipulaciones de este supuesto de elusión, será necesario demostrar el verdadero origen de las mercancías que ingresan a nuestro mercado, para ello existen dos modalidades de certificación: el certificado de origen preferencial y el certificado de origen no preferencial.

Como se sabe los acuerdos bilaterales comprenden beneficios arancelarios en favor del importador, siempre que éste compruebe el origen de los productos. ADUANAS se encarga de aplicar las prerrogativas arancelarias, mientras que la labor de MINCETUR se concentra en la verificación y fiscalización de la veracidad de los datos estipulados en el Certificado de Origen Preferencial con el cual se ha logrado la desgravación arancelaria.

Por otro lado, el objeto del Certificado de origen no preferencial no alude a la obtención de una preferencia arancelaria, sino que se dirige a demostrar un origen distinto al del país sobre el que se han aplicado medidas de defensa comercial, tal como el derecho antidumping. Por ejemplo, imaginemos que el gobierno peruano aplica medidas 
antidumping a las importaciones de los tejidos de mezclilla (DENIM), con subpartida nacional número 5209.42.00.00, proveniente de la República de China. Por su parte, un agente comercial en Perú importa dicho producto desde Estados Unidos, por lo que, para deslindar, en materia de origen, cualquier relación del producto con algún productor o exportador chino, se podría presentar un Certificado de Origen no Preferencial con el cual ADUANAS no podría cobrar medidas de defensa comercial.

En nuestro país existía un modelo para la emisión de estos últimos certificados, sin embargo, confluyeron tres razones que determinaron la sustitución de este requerimiento por una Declaración de Origen de la Mercancía: la afectación que generaban las condiciones y formalidades adscritas a este documento, la problemática que surgía para la verificación de la autenticidad de los certificados por parte de Aduanas y la intención de favorecer el flujo comercial. Con arreglo a ello, la normativa que regula el origen de las mercancías sujetas a medidas de defensa comercial es, el antes citado, Decreto Supremo $\mathrm{N}^{\circ}$ 005-2011MINCETUR.

Asimismo, conviene precisar que aquella normativa deberá ser tomada en cuenta conjuntamente con las Resoluciones Ministeriales, emitidas por MINCETUR ${ }^{46}$. Estas resoluciones establecen los criterios para determinar el origen de mercancías sujetas a las medidas antidumping, por ejemplo, podemos citar la Resolución Ministerial № 338 y 339 del 2005, los cuales establecen las reglas de origen para cierres y articulo de loza y porcelana; Resolución Ministerial N 075 y 076 del 2006, el cual establece las reglas para bisagras y tejidos; y la Resolución Ministerial Nº74 del 2007, el cual fija las reglas de origen para calzado.

La labor, en este caso, era tripartita: por un lado, la Comisión de INDECOPI determinaba la aplicación de derechos antidumping sobre la importación de determinados producto; por su parte, MINCETUR emitía las Resoluciones Ministeriales que delimitaban, de forma específica y personalizada, los criterios de origen para cada mercancía sujeta a

46 Como bien confirma el Artículo 9 del Decreto Supremos 005-2011-MINCETUR:

Para la determinación del origen de las mercancías a que se refiere el numeral 1.1. del Artículo 1, son de aplicación los criterios de origen específicos aprobados a tal efecto mediante Resolución Ministerial del Sector Comercio Exterior y Turismo. 
medida de defensa comercial; finalmente, SUNAT se encargaba de aplicar las pautas esgrimidas por MINCETUR para fiscalizar la veracidad del origen declarando, cobrando, cuando corresponde, los derechos antidumping. Esta triangulación de labores resultaría eficiente en tanto cada institución cumpla con las condiciones de origen pre establecidas, sin embargo, muchos productores nacionales acusaban que SUNAT no tomaba en consideración las Resoluciones Ministeriales, por lo que, su labor de control y fiscalización del origen no preferencial no era detallada.

Por todo lo antes señalado y en base a la normativa actual, entendemos que cuando la Comisión específica, en la propuesta de modificación del Reglamento Antidumping, que no se ha verificado el origen de la mercancía "conforme a la normativa de la materia", se hace referencia al Decreto Supremo $\mathrm{N}^{\circ}$ 005-2001-MINCETUR y a las Resoluciones Ministeriales emitidas por MINCETUR. Se deberá garantizar que la SUNAT actúe en cumplimiento de estos instrumentos legales, pues es esta institución la que finalmente las efectiviza y ejecuta.

Creemos que hay principalmente dos razones que sustentan la viabilidad de esta propuesta. En primer lugar, sostenemos que la aplicación conjunta de disposiciones antielusivas y normas de control y fiscalización de origen no preferencial no implica incurrir en una redundancia legal, como diversos detractores han sostenido. Se ha dicho que no es necesario incluir esta fórmula dentro de la propuesta, pues existen disposiciones que se concentran en el fraude de origen, por lo que, bastaría con aplicar enérgicamente la normas ya vigentes; claramente ello no es exacto, pues existen dos conductas diferenciadas, por un lado, el "fraude de origen", al que se ha hecho referencia, incide sobre los delitos aduaneros que se aplican cuando se presentan documentos con información falsa en relación al origen $^{47}$, los cuales generan una infracción a nivel aduanero, siempre que se obtenga un beneficio ilícito, por lo que, se entiende que este precepto gira en torno al origen

$47 \quad$ Artículo 5.- Modalidades de Defraudación de Rentas de Aduanas

Constituyen modalidades del delito de Defraudación de Rentas de Aduana y serán reprimidos con las penas señaladas en el Artículo 4, las acciones siguientes:

a) Importar mercancías amparadas en documentos falsos o adulterados o con información falsa en relación con el valor, calidad, cantidad, peso, especie, antigüedad, origen u otras características como marcas códigos, series, modelos, que originen un tratamiento aduanero o tributo más favorable al que corresponde a los fines de su importación. 
preferencial. Por otro lado, la falsa declaración de origen es un medio para perpetrar una conducta desleal en contra del sistema dumping, lo que constituye una segunda conducta sujeta a la extensión de derechos antidumping.

Si bien el Decreto Supremo 005-2011-MINCETUR y las propuestas de las medidas antielusión persiguen objetivos distintos, éstos pueden complementarse perfectamente para eliminar las distorsiones en el comercio internacional, ello es justamente el segundo fundamento que explica la conveniencia de esta propuesta.

Por lo antes dicho, nuestra posición consiste en reconocer la utilidad de incluir esta fórmula elusiva dentro de las disposiciones del Reglamento Antidumping.

\subsubsection{CUARTA Y QUINTA FÓRMULA ELUSIVA:}

Por cuestión de afinidad normativa, analizaremos conjuntamente dos fórmulas elusivas: mercancías que sufren modificaciones o alteraciones menores y productos que se sujetan a un proceso posterior de desarrollo. A continuación el tenor de las propuestas:

La importación del producto sujeto a derechos antidumping con modificaciones o alteraciones menores que no impliquen un cambio en sus características esenciales, aun cuando el producto importado ingrese al Perú a través de una partida arancelaria distinta. En este caso se podrán evaluar los siguientes criterios: (i) características físicas (ii) expectativas de los compradores (iii) usos final (iv) canales de comercialización (v) intercambiabilidad de los productos (vi) procesos productivos (vii) diferencias en los costos de producción (viii) costos de transformación del producto con modificaciones o alteraciones.

La importación del producto sujeto a un derecho antidumping que haya sido sometido a un proceso posterior de desarrollo luego de la aplicación del derecho. En este caso se verificará que el producto desarrollado posteriormente: 
(i) Comparta características físicas y usos similares que el producto sujeto a derechos, aun cuando ingrese al Perú a través de una partida arancelaria distinta a la considerada en la investigación; y,

(ii) Permita al comprador ejecutar las mismas funciones que el producto sujeto a derechos. Cuando permita ejecutar funciones adicionales, éstas no deben constituir el uso primario del producto desarrollado posteriormente $\mathrm{y}$ el costo de tales funciones adicionales no debe representar más que una proporción significativa del costo total de producción.

(INDECOPI, 2011, pág.21)

Empezaremos señalando que ambos supuestos comprenden una categoría más amplia conocida, según la terminología en inglés, como Side-stream Circumvention. Por un lado, las modificaciones o alteraciones menores pueden concentrarse en el cambio de la presentación, apariencia o empaque. Para graficar las circunstancias que caracterizan está formula, haremos alusión a un caso resuelto por la autoridad mexicana:

El 2007 la autoridad mexicana detectó la ejecución de prácticas elusivas por parte de productores brasileros quienes decidieron exportar sacos de dos capas de papel para cemento en vez de enviarlos en sacos de tres capas de papel como se determinó en la investigación antidumping. Como se puede observar, la intención fue alterar el empaque para poder modificar el producto y evitar el pago de derechos antidumping.

Por otro lado, el proceso posterior de desarrollo, o también conocido como the new generation product, implica un cambio en el diseño o la incorporación de características o funciones adicionales. Para ilustrar esta fórmula elusiva, presentaremos un caso sobre el que se pronunció la autoridad europea:

El 25 de enero de 1999, la autoridad europea decidió extender la aplicación de derechos antidumping originalmente destinados a la importación desde china de encendedores desechables de bolsillo a encendedores con válvulas de relleno. El propósito del productor chino era modificar la clasificación arancelaria mediante la adhesión de una 
válvula. Como puede notarse, el productor tuvo la intención de añadir una función que alterara el producto original.

Estas propuestas ha sido criticadas por empresas importadoras de productos textiles, las cuales señalan que en la industria, en la que ellos se desarrollan, las modificaciones de las mercancías es una práctica habitual, por lo que, las importaciones textiles podrían ser frecuente foco de investigaciones antielusivas.

Para aliviar las conjeturas realizadas en contra de las propuestas, la autoridad solo podrá disponer la imposición de medidas antielusivas cuando el producto originalmente considerado para la investigación antidumping y el producto objeto de la investigación antielusiva:

- Compartan las mismas características físicas generales.

- Los compradores de uno y otro producto poseen las mismas expectativas.

- Conservan el mismo uso final.

- Son vendidos a través del mismo canal de distribución.

- Son publicitados y distribuidos de una manera similar

Es decir, en la medida en que confluyan dichos elementos de juicio e independientemente de que esta práctica haya generado el cambio de la partida arancelaria, la autoridad podrá formarse un criterio sobre la existencia de conductas elusivas.

Sin embargo, se recomendaría la inclusión de la regla del 25\%, es decir, si el valor añadido conjunto en el proceso posterior de desarrollo, que incorpora una característica o función adicional, supera el $25 \%$ del costo de producción, la autoridad administrativa debería descartar la aplicación de las medidas antielusivas. Esta medida, de algún modo, busca limitar la aplicación irrestricta de este supuesto elusivo. 
A pesar de las diferencias entre uno y otro supuesto, ambas fórmulas instan a discutir sobre el alcance que tendrá el concepto de producto similar sobre aquellas. Al respecto Yanning $\mathrm{Yu}$ (2008) propone dos escenarios:

- La autoridad administrativa podrá extender la aplicación de los derechos antidumping a las mercancías alteradas, modificadas o sujetas a un proceso posterior de desarrollo que caen dentro del alcance de lo que se considera como producto similar. En este supuesto, no sería necesario incluir una investigación por daño o dumping dentro del proceso antielusivo.

- En el caso de que el producto, materia de investigación antielusiva, no se ajuste a lo que se considera como producto similar, se debería incluir una investigación para determinar la existencia de dumping o daño para poder extender las medidas antielusivas. (Pg. 40)

Como puede notarse, nuevamente resalta la importancia de esclarecer los criterios que se desarrollan en torno al producto similar. Para ello puede tomarse en cuenta los factores que, además de los establecidos en el Acuerdo Antidumping, sugiere Henrik Olsson (1999): “1) características físicas 2) uso y 3) percepción pública. La diferencia de precios podría ser otro factor que puede ser significativo para la elaboración de una determinación" (pág. 27)

La autoridad peruana deberá ser muy cautelosa en establecer si el producto materia de investigación encaja bajo los alcances de un producto similar, mediante los criterios anteriormente recomendados, pues solo así podrá establecerse qué camino tomar dentro del procedimiento antielusivo, lo que será determinante para la realización o no de una investigación de daño y dumping. 


\subsubsection{SEXTA FÓRMULA ELUSIVA:}

La autoridad competente del INDECOPI incluyó en la propuesta el siguiente supuesto de elusión:

La reorganización de los canales de importación con la finalidad de que el producto sujeto a derechos antidumping sea exportado al Perú a través de productores o exportadores beneficiados con un tipo de derecho individual inferior al que le resulta aplicable, o a los cuales no se les haya aplicado un derecho.

(INDECOPI, 2011, pág.21)

Esta disposición hace referencia al beneficio que los productores o exportadores obtienen mediante la reorganización en los canales de exportación, es decir, los productos sujetos a la aplicación de derechos antidumping son producidos por los mismos agentes comerciales, pero son exportados, al país de destino, por otro exportador al que no se le aplican medidas antidumping o el porcentaje de estos son bajos. Para ejemplificar este supuesto de elusión se ha citado el Reglamento (UE) $N^{\circ} 748 / 2010$ de la Comisión de la Unión Europea, por el que se inicia de oficio una investigación por la ejecución de posibles prácticas de elusión mediante la configuración del supuesto de elusión bajo análisis:

La Comisión posee indicios razonables suficientes de que se están eludiendo las medidas antidumping sobre las importaciones del producto afectado fabricado por determinados productores sujetos al tipo de derecho residual del $28.8 \%$ mediante una reorganización de las estructuras y los circuitos de venta del producto afecto. Estos productores y exportadores exportan finalmente sus productos a la Unión a través de un productor exportador chino que se beneficia de un tipo de derecho para exportadores cooperadores no seleccionados para formar parte de la muestra del 8.45 (Xiamen Xingia Polymers Co. Figura junto con otras empresas), tipo que es inferior al tipo de derecho residual del $28.8 \%$.

(EURLEX, 2010) 
Además, se verifica la configuración de otros criterios, tales como el cambio significativo en las características del comercio que se proyecta en la reorganización de los canales de importación, la existencia de pruebas que evidencian la afectación en los efectos correctores destinados a los derechos antidumping y la presencia de indicios que muestran que se mantienen los precios dumping respecto al valor normal establecido en la investigación antidumping original.

Una vez finalizado el procedimiento de investigación que permita a la autoridad concluir sobre la existencia de una conducta elusiva, se podrán aplicar las medidas antielusivas, las cuales consisten en la ampliación del derecho antidumping residual, establecido en la investigación antidumping original, a las importaciones realizadas por el exportador o productor a quien se le aplicaron originalmente medidas inferiores.

\subsubsection{Clausula general:}

Cualquier otra conducta que implique un cambio en las características del comercio entre terceros países y el Perú o entre empresas individuales del país sujeto a los derechos vigentes y el Perú, derivado de una práctica, proceso o trabajo para el que no exista una causa o justificación económica adecuada distinta del establecimiento del derecho antidumping. En estos casos, debe establecerse que la conducta tiene una repercusión negativa sobre los efectos correctores de los derechos en lo que respecta a los precios y las cantidades del producto similar importado, y que existe dumping en relación con el valor normal establecido en la investigación original en que se impusieron los derechos que se pretende eludir.

(INDECOPI, 2011, pág.21)

Una de las propuestas realizadas por la Comisión consiste en la inclusión de una cláusula general que será aplicada en caso se configure un supuesto elusivo que no haya sido establecido como tal y de forma expresa en la normativa, sin embargo, con ello no se pretende avalar un accionar arbitrario por parte de la autoridad administrativa, por lo que, en la Exposición de Motivos se han puntualizado tres criterios que deberán converger para 
determinar que existe efectivamente una conducta elusiva y que presentamos a continuación.

En primera instancia, se hace referencia al cambio en las características de comercio que se genera entre los productores y exportadores del país extranjero al cual le fueron aplicados derechos antidumping y los agentes comerciales del país importador. Los supuestos de elusión desarrollados líneas arriba pueden ejemplificar este cambio de una forma más clara: realizar modificaciones menores para variar la partida arancelaria de un producto, considerar la participación de un tercer país desde donde se exporten los productos dumping, incrementar las exportaciones de partes, piezas, componentes o insumos dentro del mercado doméstico; todas estas conductas evidencian un cambio en las características del comercio. Sin embargo, lo que hace que ello sea cuestionable es que sean realizadas en razón de la iniciación de un procedimiento antidumping o cuando las medidas antidumping ya han sido impuestas.

En segundo lugar, según estipula la Exposición de Motivos, los exportadores extranjeros o los importadores podrán, dentro del proceso antielusión, demostrar que su accionar no responde a conductas elusivas, sino que más bien se realizan actividades comerciales legítimas que tienen una justificación económica. Esta precisión resulta interesante, pues plantea la existencia de un punto de quiebre que diferencia dos situaciones: acciones elusivas que podrán ser castigadas mediante la extensión de las medidas antidumping originalmente aplicadas; y las gestiones comerciales que tienen como base una justificación económica que no deberían ser sancionadas, sino permitidas. Como podrá notarse la línea divisoria entre una y otra es muy sutil, por ello, se recomienda delimitar de mejor forma lo que es considerado aceptable e inaceptable; para lograrlo la autoridad podría decidirse a definir lo que se debe entender por "elusión" del pago de los derechos antidumping, pues detallar cada supuesto elusivo funge de ejemplo que sustenta la definición realizada.

Finalmente, la autoridad debe hallar evidencia de que los efectos correctores de los derechos antidumping se han visto menoscabados por causa de la ejecución de conductas elusivas. Como bien se señala, ello se hará evidente con el ingreso de importantes 
volúmenes de importaciones a precios subvalorados en relación a los precios de la rama de producción nacional, cuyo valor normal será establecido en la investigación original en que se impusieron los derechos que se pretenden eludir. (INDECOPI, 2011, pág. 15)

Ante esta propuesta, muchas instituciones se manifestaron en contra, entre ellos, la Sociedad de Comercio Exterior del Perú y la Cámara de Comercio de Lima, los cuales tildan a este precepto de amplio y peligroso para el libre comercio. Por su parte, otros grupos están de acuerdo con la medida, tal es el caso de la Sociedad Nacional de Industrias y la Corporación de cuero, calzado y afines.

Nosotros consideramos que es acertado incluir una cláusula general, pues existen razones que así lo sustentan. En primer lugar, basta con revisar la legislación comparada, lo que fue materia del capítulo anterior, para darse cuenta que son muchos los países que incluyen este tipo de disposiciones dentro de su normativa antidumping; para graficar lo antes señalado, puede revisarse la legislación de la Unión Europea y Argentina.

Por otro lado, existe una justificación lógica que refuerza la inclusión de una cláusula general y es la necesidad de cubrir las futuras, pero aún imprecisas, acciones alusivas. La autoridad no puede prever qué otras conductas serán empleadas por el exportador o productor para evitar el pago de los derechos antidumping. Sin lugar a dudas, la tecnología y la globalización ofrecen las condiciones perfectas para la innovación elusiva; son muchos los factores que forman parte del juego comercial y alguno de ellos puede ser alterado con tal de dar paso a una conducta de elusión.

La posición que se muestra en contra de la propuesta sostiene que la aplicación irrestricta de esta disposición puede generar la excesiva extensión de los derechos antidumping a supuestos que podrían ser calificadas de legítimos dentro del mercado internacional, sin embargo, lo que este acápite del proyecto busca es anticipar los nuevos supuestos elusivos y cubrir normativamente su configuración, para ello, la autoridad está obligada a verificar la convergencia de los tres requisitos explicados líneas arriba. El estudio de los supuestos elusivos, que se han ido configurando reiteradamente, han arrojado un común denominador que justamente forma parte de los tres requisitos que deberán ser 
tomados en cuenta por la autoridad administrativa para determinar que un supuesto de hecho encaja en las condiciones establecidas en la Cláusula General. Si adicionalmente se incluye una clara definición de elusión de derechos antidumping, se podría coadyuvar a que las reglas sean más precisas y predecibles, reduciendo así las posibilidades de resolver arbitrariamente.

Nuestra legislación no es ajena a la inclusión de Cláusulas Generales; claro ejemplo de ello es el Artículo 6 del Decreto Legislativo 1044, Ley de Represión de competencia desleal $^{48}$, cuyo precepto establece la prohibición general de los actos de competencia desleal para posteriormente complementarlo con un listado enunciativo de fórmulas de competencia desleal. Esta estructura es justamente la que plantea este proyecto: una clausula general que comprenda los requisitos generales y comunes de todos los supuestos elusivos y la enumeración taxativa de cada fórmula elusiva que ejemplifique la disposición general. Si además de ello se refuerza el contenido de la cláusula general con una definición de elusión de las medidas antielusivas, no habrá lugar a cuestionar esta propuesta de extensa o arbitraria.

\subsubsection{OTRAS RECOMENDACIONES:}

La propuesta de la Comisión comprende otras aristas que pueden ser analizadas y contribuir a una normativa antielusión. Por ejemplo, notamos que no se ha incluido el supuesto de elusión inverso, conocido en su terminología en inglés como downstream circumvention, esta fórmula es justamente la que se configuró en el caso de tejidos tipo popelina y consiste en la aplicación de derechos antidumping a un insumo, los cuales son eludidos mediante la incorporación de éste a un producto final, sin la realización de un proceso importante. Teniendo en cuenta que la ejecución de este supuesto fue denunciada

$48 \quad$ Artículo 6.- Cláusula General:

6.1. Están prohibidos y serán sancionados los actos de competencia desleal, cualquiera sea la forma que adopten y cualquiera sea el medio que permita su realización, incluida la actividad publicitaria, sin importar el sector de la actividad económica en la que se manifiesten. Un acto de competencia desleal es aquel que resulte objetivamente contrario a las exigencias de la buena fe empresarial que deben orientar la concurrencia en una economía social de mercado 
ante la autoridad peruana, se considera conveniente incluir esta fórmula dentro de la propuesta de modificación del Reglamento Antidumping.

Por otro lado, resulta conveniente establecer un procedimiento antielusivo más expedito en relación al procedimiento antidumping, sin embargo, debemos tener en cuenta que cada fórmula elusiva contiene criterios y características distintas, por lo que, sería recomendable que, cuando corresponda, se realicen especificaciones. Por ejemplo, en el supuesto de elusión que trata sobre la exportación de partes, piezas y componentes al país importador que aplicó las medidas paraarancelarias, se identifica que la extensión en la aplicación de derechos antidumping de forma prorrateada al valor que represente cada parte, pieza o componente en relación al valor total del producto final, podría afectar a los productores y exportadores nacionales de esas partes, piezas y componentes, por lo que, sería válido que aquellos puedan legítimamente solicitar el inicio de un procedimiento antielusión.

\subsection{UN ALCANCE ECONÓMICO SOBRE LA MODIFICACIÓN NORMATIVA}

Mediante Resolución N 083-2012/CFD-INDECOPI, la Comisión decidió iniciar, de oficio, un procedimiento antidumping sobre las importaciones de cinco categorías de prendas provenientes de China: camisas, polos, ropa interior, medias y similares, pantalones y shorts (en adelante, prendas y complementos de vestir). La iniciativa que impulsó el inicio de la investigación se basó principalmente en las circunstancias especiales del sector nacional de fabricación de prendas que se expresa en el alto nivel de atomización y la falta de organización en la industria; en la gran relevancia que tiene dicha industria doméstica para nuestra economía nacional; y en la existencia de indicios de dumping y daño.

El 06 de diciembre de 2013 se emitió la Resolución Final N²97-2013/CFDINDECOPI que, en primera instancia administrativa, resuelve la discusión mediante la aplicación de derechos antidumping definitivos. Los fundamentos jurídicos que justifican la decisión son los siguientes: 
En primer lugar, luego de equiparar el valor normal y los precios de exportación de cada productor, se determinó que existía un margen dumping en las exportaciones de ocho empresas chinas. Por su parte, los precios de exportación de dos empresas chinas arrojan un margen dumping en negativo, por lo que, en este último supuesto, los derechos antidumping no les son aplicables.

En segundo lugar, las averiguaciones realizadas durante el periodo 2009 a 2011 demostró la existencia tanto de factores con tendencia positiva como negativas. Por un lado, los factores positivos se proyectan en el crecimiento en las ventas internas y en el aumento de remuneraciones, sin embargo, la autoridad estableció que aquellas variables se desarrollaron durante un importante ritmo de expansión. Con arreglo a ello, los indicadores positivos no son necesariamente un signo de un buen desempeño de la rama de producción nacional.

Por otro lado, se comprobó la existencia de los siguientes factores con tendencia negativa: el incremento en las importaciones de prendas y complementos de vestir originarias de China, el crecimiento en la participación de éstos en el mercado interno, el aumento en la participación de productos chinos en la demanda interna y la invariabilidad en el margen de subvaloración.

El análisis del conjunto de factores proyectó la existencia de daño, el cual genera un detrimento de la rama de producción nacional de prendas y complementos de vestir.

Finalmente, con arreglo al último requisito exigido por el Reglamento Antidumping, se precisó que existen pruebas de la existencia de una relación causal entre el crecimiento de la importaciones de prendas y complementos de vestidos provenientes de china y el deterioro de los principales indicadores económicos.

Ante la convergencia de los tres indicadores concluyentes de prácticas dumping, la Comisión dispuso la aplicación de derechos antidumping definitivos con un tope diferenciado para cada categoría de mercancía y respecto a cada exportador. 
Esta decisión fue muy controversial y provocó la publicación de varios artículos expresando posiciones en contra. Entre ellos podemos citar los siguientes pronunciamientos:

Estudios Económicos de COMEXPERU (2013) calificó de incongruente el pronunciamiento del Presidente de la Coordinadora de Empresas de Gamarra, pues, en un primer momento, manifestó que Gamarra crecería un 10\% respecto a 2012, facturando más de US\$ 1650 millones de dólares en 2013, sin embargo, posteriormente, anunció que, por causa de la competencia desleal que implicaba la subvaloración y el dumping, la cuota de participación de Gamarra sufriría una pérdida en el mercado nacional lo que podría verse reflejado en la salida del mercado de 14000 empresas peruanas. COMEXPERU descalificó las aseveraciones de afectación de la industria textil y concluyó con que la autoridad no debe contravenir la apertura comercial con acciones proteccionistas. (pág. 27)

El jefe de Estudios Económicos de COMEXPERU, criticó el procedimiento antidumping realizado por la Comisión y puntualizó que la inclusión de 276 partidas determinaría una investigación amplia y compleja; la iniciación del procedimiento de oficio sin contar con las pruebas necesarias; la aplicación de sanciones a exportadores y productores del sector que no cumplían los requerimientos de información solicitado por la Comisión; el incumplimiento de plazos y la violación de normas de la OMC. Según su opinión, los hechos, que determinan la investigación, ponen en tela de juicio el prestigio de INDECOPI y atenta en contra de la imagen de socio comercial confiable y técnicamente responsable de Perú. Zacnich no termina sin antes azuzar y generar temor sobre los exportadores peruanos que hacen envíos a China y los consumidores peruanos más pobres, por las consecuencias, según él, negativas que traería el procedimiento antidumping. (Zacnich, 2013, pág. 15)

La disconformidad con lo resuelto en primera instancia fue tal que la causa se sometió a un recurso de apelación, por lo que, el caso fue derivado a la Sala Especializada en la Defensa de la Competencia de INDECOPI. En este procedimiento participaron Supermercados Peruanos S.A., como administrado y 76 partes, entre personas naturales, personas jurídicas, e instituciones estatales. El caso concluyó con la Resolución 02932015/SDC-INDECOPI, el cual revocó la Resolución 297-2013/CFD-INDECOPI que 
dispuso imponer derechos antidumping definitivos a las importaciones de prendas y complementos de vestir confeccionados con tejidos de punto y tejidos planos procedentes de China; y, en tal sentido, se dejó sin efecto los mencionados derechos. Tal decisión se basó en ciertas deficiencias expresadas en la Resolución emitida por la Comisión:

Esta Sala advierte que la primera instancia omitió realizar un análisis de identificación del mercado pertinente del producto considerado, es decir, no demostró fehacientemente que todos los artículos que integran el producto investigado competían en un único mercado. De igual forma, no determinó correctamente la similitud del producto nacional con respecto al producto considerado definido por la primera instancia, pues omitió efectuar un análisis sobre la existencia de una relación de competencia que incluya la percepción de los consumidores y que contemple un examen de sustitución y rivalidad de los productos. Esto último resultaba necesario dada la amplitud y heterogeneidad de los artículos que conforman el producto investigado en el presente caso. Resolución 0293-2015/SDC-INDECOPI

Según señala Raúl Saba, Vicepresidente del Comité Textil de la Sociedad Nacional de Industrias, el ingreso, a nuestro mercado, de importaciones de hilado, tejidos y prendas de vestir, provenientes mayormente de países asiáticos, han generado un detrimento en la industria de confecciones y textiles, las cuales generan el 1,9\% del total del PBI y de la que dependen 400000 puestos de trabajo directo y 2,8 millones de personas indirectamente. Esta afectación habría generado el cierre de muchas plantas de producción y la proyección de las siguientes cifras: la producción de textiles viene cayendo desde el 2011 de manera sostenida a razón de 0,6\% anual en promedio, mientras que la producción en la industria de confecciones lo hace a 4,9\% anual en promedio desde el año 2010. Del mismo modo, las exportaciones de textiles han caído $0,1 \%$ y las de confecciones, $3,9 \%$ en promedio. Por todo ello, Saba lamenta la actitud pasiva que tienen las autoridades frente a la problemática que acarrean las prácticas dumping. (El Comercio, 2016) 
La razón por la que exponemos este controversial y polarizado caso es por la importante incidencia que los procedimientos antidumping y, más específicamente, las medidas antidumping tienen a nivel tanto comercial como económico.

Por su parte, la propuesta de modificación del Reglamento Antidumping ha generado una incisiva discusión, debido a que, al igual que los derechos antidumping, la posible inclusión de medidas antielusivas en el sistema de defensa comercial concibe diversas consecuencias comerciales y económicas. Por lo que, a continuación, identificaremos las implicancias que acarrearía la propuesta planteada:

- La OMC encomendó, a la autoridad competente de cada país, la tarea de eliminar las distorsiones generadas en el mercado; para lograr tal fin, la Comisión puede recurrir a la aplicación de medidas antidumping que equilibrará una situación de precios a nivel inferior. Sin embargo, la creciente ejecución de prácticas de elusión busca perpetuar un contexto de distorsión en el mercado. En razón de ello, la inclusión de medidas antielusivas en el sistema de defensa comercial va a garantizar el cumplimiento de la labor delegada en la autoridad, consistente en mantener las condiciones que existirían normalmente en un mercado competitivo; por lo que, el cambio normativo ofrecería una ventajas a un nivel multilateral.

- Las industrias que se han mostrado especialmente vulnerables y las que, mayormente, respaldan las modificaciones normativas son las de Cuero, calzado y afines, así como la Industria textil. Sin embargo, la propuesta de modificación normativa no se concibe para brindar exclusiva protección a dichas industrias, como han venido acusando las posiciones en contra, sino que nace para proteger el sistema antidumping, garantizar el cumplimiento de las resoluciones administrativas y efectivizar el pago de los derechos antidumping, cuyo pago se pretende eludir. Un marco normativo antielusivo va a favorecer al conjunto de industrias peruanas, en tanto, se va a fortalecer la confianza que sienten éstos, en su calidad de administrados, en el esquema diseñado para la protección de las ramas de 
producción nacional frente a importaciones de productos a precios dumping que generen un daño o que amenacen con crearlo.

Imaginemos que un conjunto de empresas que representan el 25\% de la producción nacional total de determinado producto solicita el inicio de una investigación antielusiva, el cual es atendido por la Comisión y, tras un año de averiguaciones, culmina con la imposición de derechos antidumping sobre la importación del producto sobre el cual recae el caso. Los exportadores o productores extranjeros al ver que sus precios han sido equilibrados de acuerdo al valor normal considerado en la investigación, deciden incurrir en prácticas de elusión, lo que les permitirá burlar los efectos correctores aplicados por la autoridad del país importador. Cuando las empresas peruanas identifiquen que la conducta desleal se perpetúa mediante la ejecución de fórmulas elusivas, acudirán ante la autoridad, exigiendo se extiendan las medidas antidumping, sin embargo, la Comisión, al no contar con un respaldo normativo que le permita enfrentar las conductas de elusión, deberá inhibirse de conocer el caso. Todo ello generará incertidumbre e inseguridad en las empresas peruanas quienes, para hallar protección, han tenido que, primero, organizarse para poder cumplir con los márgenes exigidos para el inicio del procedimiento antidumping $\mathrm{y}$, segundo, invertir tiempo y dinero para hacer seguimiento al procedimiento. Sin embargo, el vacío legal existente, les dejará una sensación de desazón, pues se proyectará la percepción de que las medidas antidumping son fácilmente burladas, lo que, a su vez, acarreará una desconfianza en el sistema de defensa comercial en su conjunto.

Se identifica, entonces, que uno de los beneficios que genera la modificación del Reglamento Antidumping, a nivel comercial, es la confianza que la autoridad administrativa proyectará en los administrados respecto a la eficiencia del sistema antidumping y la capacidad de éstas para hacer frente a conductas de elusión. Por lo que, se expone una dualidad de ventajas: generar confianza en los administrados y empoderar a la administración a cumplir, efectivamente, con los objetivos establecidos por la OMC. 
- En la medida que se adecuen procedimientos especialmente diseñados para cada supuesto elusivo, todos los agentes que participan en la investigación, sean éstos exportadores, productores, importadores o instituciones estatales del país investigado o del que investiga podrán ahorrar tiempo y dinero. Desde este punto de vista, el correcto desarrollo de las disposiciones procedimentales va a generar beneficios en favor de la administración y los administrados.

- Resulta importante tener en cuenta que la firma de un Tratado de Libre Comercio implica el desgravamen de los aranceles, otorgando preferencias comerciales a los países participantes. Por ejemplo, en el caso del TLC suscrito entre China y Perú se ha dispuesto que, a partir del 2026, determinados productos provenientes del país asiático ingresen a nuestro mercado con un desgravamen del 100\%.

Con relación a las preferencias comerciales, el ex Presidente de la Sociedad Nacional de Industrias, el Señor Luis Salazar, señala que:

Si bien se entiende que la reducción arancelaria ha sido concebida con la intencionalidad positiva y correcta de tratar de incentivar la industria local, existen sectores sensibles, tales como los sectores de agricultura, textil, químico y pesca para el consumo humano, que se ven afectados con dichas medidas. Ello se debe, según señala, a que no se tuvo en cuenta las diferentes aristas que tiene el tema arancelario, por lo que, se exhorta a la revisión de los efectos generados por la reducción de aranceles.

(Gestión, 2014)

Innegablemente, los acuerdos comerciales bilaterales ofrecen considerables beneficios a ambos países; específicamente, China es un socio comercial estratégico que impulsó nuestro crecimiento económico y comercial, incluso el 2008, tras la crisis financiera en Estados Unidos, mantuvimos cierta estabilidad, pues nuestras exportaciones son diversificadas, por lo que, no dependíamos comercialmente del mercado norteamericano, sino que se mantuvo un buen nivel de ventas de materia prima en el país asiático. 
Con arreglo a las conjeturas realizadas líneas arriba, podemos señalar que la firma de un TLC condiciona la concurrencia de ciertas consecuencias que deberán ser asumidos por los países participantes, como la completa desgravación arancelaria, sin embargo, no debe perderse de vista que ello determinará un mayor flujo comercial, por lo que, se incrementarán las exportaciones e importaciones entre uno y otro país. No obstante, este contexto comercial podría significar, paralelamente, el aumento de prácticas dumping y de elusión. Por todo ello, es lógico que se prevea un sistema de defensa comercial reforzado que permita la eliminación de conductas desleales y prácticas elusivas que impliquen una distorsión en el correcto flujo comercial. Asimismo, con el propósito de preservar las buenas relaciones comerciales con países estratégicos, la propuesta normativa de modificación deberá ser los más clara, previsible y detallada posible; solo así se podrán percibir beneficios.

Como se sabe INDECOPI dispone de sus propios fondos, los cuales se generan de recaudos, multas y tasas. Por lo que, la implementación normativa del proyecto no implicará un gasto para el Presupuesto Nacional establecido por el gobierno peruano. Por ello, el Proyecto especifica que "No se comprometerán fondos del Tesoro Público en la implementación de las modificaciones propuestas en el proyecto normativo, en la medida que los costos de tramitación de los procedimientos antielusión serán financiados íntegramente con las tasas administrativas que directamente recaude el INDECOPI" (INDECOPI, 2011, pág.19).

- Uno de los beneficios más resaltantes consiste en el efecto positivo que la modificación normativa podría generar sobre las cifras de los reportes contables de nuestro país. Existen diferentes factores que inciden en los resultados proyectados en el PBI y la Balanza de Pagos, nos atrevemos a señalar que uno de ellos, es el contexto legal que regula las transacciones en el comercio internacional, por lo que, la inclusión de medidas antielusivas, que refuercen el sistema antidumping, podría ser una variable que genere alguna repercusión. 
Por un lado, según señala se señala "la Balanza de Pagos es un documento contable en el que se registran, de manera sistemática, las operaciones comerciales, de servicios y de movimientos de capitales llevadas a cabo por los residentes en un país con el resto del mundo durante un período determinado, normalmente un año. La balanza de pagos suministra información detallada sobre todas las transacciones entre residentes y no residentes". (Ministerio de Economía y Finanzas, 2016)

Figura 6.1

Balanza de Pagos de Perú desde el 2002 al 2015

\begin{tabular}{|c|c|c|c|c|c|c|c|c|c|c|c|c|c|c|}
\hline \multirow[t]{2}{*}{$\begin{array}{l}\text { BALANZA DE PAGOS } \\
\text { (Millones de USS) }\end{array}$} & & & & & & & & & & & & & & \\
\hline & 2002 & 2003 & 2004 & 2005 & 2006 & 2007 & 2008 & 2009 & 2010 & 2011 & 2012 & 2013 & 2014 & 2015 \\
\hline I. BALANZA EN CUENTA CORRIENTE & -1094 & -930 & 60 & 1159 & 2912 & 1521 & -5285 & -614 & -3545 & -3177 & -5120 & -8.582 & -8.196 & -9.210 \\
\hline 1. Balanza comercial & 321 & 886 & 3004 & 5286 & 8986 & 8503 & 2569 & 6060 & 6988 & 9224 & 6393 & 504 & -1.509 & -3.150 \\
\hline a. Exportaciones FOB & 7714 & 9091 & 12809 & 17368 & 23830 & 28094 & 31018 & 27071 & 35803 & 46376 & 47411 & 42.861 & 39.533 & 34.236 \\
\hline b. Importaciones FOB & -7393 & -8205 & -9805 & -12082 & -14844 & -19591 & -28449 & -21011 & -28815 & -37152 & -41018 & -42.356 & -41.042 & -37.385 \\
\hline 2. Servicios & -994 & -900 & -732 & -834 & -737 & -1192 & -2056 & -1176 & -2353 & -2244 & -2420 & -1.801 & -1.730 & -1.732 \\
\hline a. Exportaciones & 1455 & 1716 & 1993 & 2289 & 2660 & 3152 & 3649 & 3636 & 3693 & 4264 & 4915 & 5.814 & 5.950 & 6.226 \\
\hline b. Importaciones & -2449 & -2616 & -2725 & -3123 & -3397 & -4344 & -5704 & -4812 & -6046 & -6508 & -7335 & -7.615 & -7.680 & -7.958 \\
\hline 3. Renta de factores & -1440 & -2125 & -3645 & -5065 & -7522 & -8299 & -8742 & -8385 & -11205 & -13357 & -12399 & -10.631 & -9.328 & -7.659 \\
\hline a. Privado & -751 & -1301 & -2758 & -4238 & -6870 & -7895 & -8746 & -8450 & -10976 & -12821 & -11670 & -9.773 & -8.620 & -6.929 \\
\hline b. Público & -690 & -825 & -888 & -827 & -652 & -403 & 4 & 65 & -230 & -537 & -729 & -859 & -708 & -730 \\
\hline 4. Transferencias corrientes & 1019 & 1209 & 1433 & 1772 & 2185 & 2508 & 2943 & 2887 & 3026 & 3201 & 3307 & 3.346 & 4.372 & 3.331 \\
\hline II. CUENTA FINANCIERA & 2055 & 636 & 2091 & 211 & 273 & 8497 & 8624 & 2287 & 13638 & 8716 & 19812 & 11.414 & 6.828 & 10.966 \\
\hline 1. Sector privad & 2369 & 301 & 983 & 896 & 2495 & 8154 & 9569 & 4200 & 11467 & 9271 & 15792 & 14.881 & 6.490 & 8.043 \\
\hline & 480 & 187 & 879 & -449 & -993 & -1722 & -1507 & 172 & 2429 & 62 & & -1.343 & -16 & 3.957 \\
\hline 3. Capitales de corto plazo & -794 & 147 & 230 & -236 & -1229 & 2065 & 562 & -2085 & -258 & -1217 & 2572 & -2.125 & 354 & -1.034 \\
\hline III. FINANCIAMIENTO EXCEPCIONAL & 14 & 64 & 26 & 100 & 27 & 67 & 57 & 36 & 19 & 33 & 19 & 5 & 10 & $\mathbf{0}$ \\
\hline IV. ERRORES Y OMISIONES NETOS & -142 & 707 & 174 & 158 & -459 & -430 & -226 & -666 & 1079 & -886 & 96 & 70 & -820 & -1.684 \\
\hline $\begin{array}{l}\text { V. FLUJO DE RESERVAS NETAS DEL BCRP } \\
\qquad(\mathrm{V}=1+(\mathrm{II}+\mathrm{III}+\mathrm{IV})\end{array}$ & 833 & 477 & 2351 & 1628 & 2753 & 9654 & 3169 & 1043 & 11192 & 4686 & 14806 & 2.907 & -2.178 & 73 \\
\hline
\end{tabular}

Fuente: BCRP, MEF, SBS, SUNAT, MRE, COFIDE, ONP, FCR, ZOFRATACNA, BN, Cavali S.A.ICLV, Proinversión, BIS y empresas.

Elaboración: Gerencia Central de Estudios Económicos del Banco Central de Reservas del Perú

Como se aprecia, la Balanza Comercial ha reportado, durante los años 2014 y 2015 , un déficit comercial de $-1,509$ y de $-3,150$ respectivamente. Ello se traduce en la superposición de las cifras de las importaciones sobre las de exportaciones, es decir, importamos mercancías más de lo que exportamos. Por un lado, los principales proveedores de mercancías importadas provienen de China, Estados Unidos, Brasil, México y Corea del Sur. Mientras que, según se muestra en el siguiente cuadro, las exportaciones, específicamente del sector textil, se realizan a 
Estados Unidos, Brasil, Ecuador entre otros, sin embargo, éstas últimas se han visto reducidas con una diferencia porcentual de -26,5 entre los años 2014 y 2015:

Figura 6.2

Principales destinos: exportaciones textiles en millones de dólares

\begin{tabular}{|c|c|c|c|c|c|c|c|c|}
\hline \multirow[b]{3}{*}{ Pais } & \multicolumn{8}{|c|}{$\begin{array}{l}\text { PRINCIPALES DESTINOS: EXPORTACIONES TEXTILES } \\
\text { (Mllones do USS) }\end{array}$} \\
\hline & \multirow{2}{*}{$\frac{2014}{d c .}$} & \multicolumn{2}{|c|}{2015} & \multicolumn{2}{|c|}{ Diciembre } & \multicolumn{3}{|c|}{ Ano } \\
\hline & & Nov. & Dic. & $\begin{array}{l}\text { Var. N mes } \\
\text { anterior }\end{array}$ & $\begin{array}{l}\text { Var. } \% 12 \\
\text { meses }\end{array}$ & 2014 & 2015 & Var. \% \\
\hline Estados Unidos & 54 & 46 & 52 & 11,5 & $-5,2$ & 663 & 603 & $-9,0$ \\
\hline Brasil & 12 & 4 & 5 & 33.3 & $-59,4$ & 119 & 82 & -31.6 \\
\hline Ecuador & 6 & 4 & 3 & $-26,3$ & $-44,0$ & 107 & 73 & $-32,5$ \\
\hline Colombia & 6 & 4 & 4 & 1,8 & $-31,5$ & 101 & 64 & $-36,5$ \\
\hline Chile & 6 & 5 & 5 & $-10,7$ & $-19,7$ & 77 & 59 & $-23,1$ \\
\hline Italia & 6 & 4 & 4 & -5.4 & $-41,2$ & 63 & 50 & $-20,1$ \\
\hline Venezuela & 11 & 2 & 2 & $-23,8$ & $-83,5$ & 271 & 41 & $-85,0$ \\
\hline Alemania & 5 & 3 & 5 & 87.0 & $-11,8$ & 45 & 39 & -13.4 \\
\hline Bolivia & 4 & 3 & 3 & $-3,5$ & $-29,7$ & 42 & 34 & $-18,8$ \\
\hline México & 4 & 3 & 3 & $-11,5$ & $-22,0$ & 38 & 29 & $-23,9$ \\
\hline Resto & 21 & 22 & 21 & $-6,9$ & $-1,6$ & 274 & 250 & $-8,5$ \\
\hline Total & 136 & 101 & 106 & 4,2 & $-22,2$ & 1800 & 1324 & $-26,5$ \\
\hline Total sin Venezuela & 125 & 99 & 104 & 4,9 & $-17,0$ & 1529 & 1283 & $-16,1$ \\
\hline
\end{tabular}

Fuente: SUNAT

Elaboración: Gerencia Central de Estudios Económicos del BCR del Perú

Como se nota, la Balanza Comercial está arrojando resultados negativos y esta proyección parece extenderse para el año en curso. Por ello, la consigna consiste en aumentar nuestras exportaciones, para lograrlo deberán confluir diversos factores, entre ellos el contexto normativo que respalde a nuestro productores frente a prácticas desleales en el comercio internacional.

Por otro lado, el Producto Bruto Interno "es el valor monetario de los bienes y servicios finales producidos por una economía en un período determinado. Producto se refiere a valor agregado; interno se refiere a que es la producción dentro de las fronteras de una economía; y bruto se refiere a que no se contabilizan la 
variación de inventarios ni las depreciaciones o apreciaciones de capital” (MEF, (s.f.)).

La siguiente tabla muestra el PBI por actividad con arreglo al valor agregado bruto $^{49}$ de diversas mercancías producidas en nuestro país. En el segundo trimestre del 2016 se observan resultados negativos en los siguientes rubros del sector manufacturero: la industria alimenticia con el $-23,9 \%$, la industria textil y de cuero con el $-7,1$, la industria de madera y muebles con el $-8,0$ y la fabricación de productos minerales no metálicos con $-0,5$.

Figura 6.3

Manufactura: Valor agregado bruto

MANUFACTURA: VALOR AGREGADO BRUTO

(Variación porcentual del índice de volumen fisico respecto al mismo periodo del año anterior) Valores a precios constantes de 2007

\begin{tabular}{|c|c|c|c|c|c|c|c|c|}
\hline \multirow[b]{2}{*}{ Actividades } & \multicolumn{4}{|c|}{$2015 / 2014$} & \multicolumn{4}{|c|}{$2016 / 2015$} \\
\hline & I Trim. & II Trim. & I sem. & $\begin{array}{c}4 \text { últimos } \\
\text { Trim. }\end{array}$ & I Trim. & II Trim. & I sem. & $\begin{array}{l}4 \text { últimos } \\
\text { Trim. }\end{array}$ \\
\hline Manufactura & $-4,5$ & 0,2 & $-2,1$ & $-2,5$ & $-2,7$ & $-7,9$ & $-5,4$ & $-3,3$ \\
\hline Industria alimenticia & $-6,1$ & 8,9 & 1,8 & $-0,1$ & 0,5 & $-23,9$ & $-13,2$ & $-5,7$ \\
\hline Industria textil y de cuero & $-9,7$ & $-2,2$ & $-6,2$ & $-6,3$ & $-5,0$ & $-7,1$ & $-6,0$ & $-5,5$ \\
\hline Industria de madera y muebles & 4,4 & 8,7 & 6,5 & 2,6 & 1,6 & $-8,0$ & $-3,2$ & 1,2 \\
\hline Industria del papel, edición e impresión & $-9,8$ & $-1,2$ & $-6,1$ & $-2,8$ & 3,3 & 0,3 & 1,9 & $-2,3$ \\
\hline Industria química & $-5,0$ & $-0,1$ & $-2,6$ & $-2,6$ & $-0,1$ & 0,3 & 0,1 & 0,8 \\
\hline Fabricación de productos minerales no metálicos & 0,8 & $-5,7$ & $-2,6$ & 0,1 & $-1,2$ & 1,7 & 0,3 & $-2,0$ \\
\hline Industrias metálicas básicas & $-1,1$ & $-3,5$ & $-2,3$ & $-5,0$ & $-3,7$ & 0,2 & $-1,7$ & $-0,2$ \\
\hline Fabricación de productos metálicos & 2,5 & $-1,1$ & 0,6 & 0,2 & $-12,4$ & $-0,5$ & $-6,2$ & $-4,3$ \\
\hline Productos manufacturados diversos & $-14,0$ & $-13,0$ & $-13,5$ & $-11,3$ & $-7,9$ & $-13,7$ & $-11,0$ & $-12,3$ \\
\hline
\end{tabular}

Fuente: Instituto Nacional de Estadística e Informática Elaboración: INEI

El efecto económico más importante de la propuesta normativa puede verse proyectado en los reportes del PBI y la Balanza Comercial. Una vez que se brinden las herramientas y el contexto legal que avale el trabajo de los agentes comerciales en contra de las distorsiones comerciales, nuestra industria se podrá desarrollar eficiente y competitivamente.

49

El BCR del Perú prescribe que el Valor Agregado Bruto (VAB): "está conformado por la suma de valores agregados (diferencia entre el valor bruto de producción y el consumo intermedio) de los distintos sectores productivos. Sin considerar los impuestos a los productos y derechos de importación" (BCR del Perú, (s.f.)). 


\subsection{UNA PROYECCIÓN HACIA EL FUTURO}

\subsubsection{DESDE LA PERSPECTIVA DEL GOBIERNO PERUANO:}

Nuestra visión legal ofrece propuestas equilibradas y moderadas que implican la participación del gobierno peruano en, principalmente, dos niveles: por un lado, la protección del sistema antidumping, garantizando la ejecución de medidas correctivas y cubriendo algún vacío legal que pueda atentar en contra de este sistema, pero actuando, paralelamente, en cumplimiento del principio de legalidad y bajo las directrices establecidas expresamente por la norma, evitando caer en arbitrariedades o excesos. Por otro lado, el impulso de tecnología, innovación, productividad y capacitación, repotenciando el factor competitivo de nuestras industrias frente a la participación de agentes comerciales de otros países que exportan sus productos a nuestro mercado nacional.

Como se concluye del análisis del presente trabajo entorno a la casuística internacional y nacional, es innegable la existencia de prácticas elusivas que buscan evitar el pago de derechos antidumping. Ello justificó la emisión de normas antielusivas en la Unión Europea y Estados Unidos, medida que fue replicada por varios países en América, tales como Argentina, Uruguay, México, Colombia, Canadá, entre otros. Es decir, en sus transacciones comerciales internacionales, nuestros productores y exportadores deberán enfrentarse y sujetarse a las legislaciones antielusivas de otros países. Mientras que en nuestro caso, se evidencia un vacío legal que nos coloca en una situación de desventaja e indefensión. Con arreglo a ello se propone la modificación de nuestro Reglamento Antidumping mediante la inclusión de disposiciones antielusivas cuyo objetivo es ratificar los efectos correctores adscritos a las medidas antidumping, garantizando el correcto funcionamiento del sistema antidumping.

Nuestro país ha sabido posicionarse en el mercado internacional, obteniendo importantes aliados comerciales y articulando una significativa red de compradores. Es menester seguir proyectando la imagen de un país competitivo, alejado de conductas 
proteccionistas, por lo que, esta modificación deberá ser lo suficientemente clara y detallada, pues ello permitirá delimitar los márgenes bajo los cuales se deberá orientar el quehacer de la autoridad administrativa.

En caso el Congreso conozca de la propuesta de modificación del Reglamento Antidumping, se deberá tener en cuenta que esta iniciativa normativa responde a una problemática que forma parte de la coyuntura de comercio internacional. Con ello no se busca ofrecer una ventaja indebida a las industrias de nuestro mercado interno, sino que se promueve la elaboración de un marco legislativo apropiado para impulsar la leal competencia, libre de distorsiones.

Por otro lado, el gobierno deberá promover políticas de gobierno dirigidas a fomentar el desarrollo de un comercio industrializado, inclusivo y sostenible. Es importante que el Estado peruano otorgue las herramientas necesarias para que las diferentes industrias domésticas se organicen y procuren ser más competitivas con relación a otros protagonistas comerciales. Un claro ejemplo de ello fue la XV reunión de la Conferencia General para el Desarrollo Industrial de la ONUDI, el cual se llevó a cabo en nuestro país el pasado 02 de diciembre de 2013. Al respecto la ex Ministra de Producción, la Señora Gladys Triveño precisó que:

Creemos firmemente que el próximo paso en el desarrollo del Perú debe ser la industrialización inclusiva, privilegiando la descentralización de la actividad industrial, la ampliación de la base productiva y la sofisticación de la misma, con el fin de generar mayores niveles de empleo de calidad. Esta es la aspiración de todos los países en vías de desarrollo, y sabemos que no es una tarea fácil.

(Agencia Peruana de Noticias, 2013)

Por su parte, el ex Presidente, en la XV Conferencia General de ONUDI en Lima se manifestó que la industrialización en el Perú es tibia e incipiente, por lo que, resultaba importante incidir en el fortalecimiento del desarrollo industrial del país, para alcanzar dicho objetivo, se anunció la implementación del Plan Nacional de Industrialización el cual prevé la reconvención laboral, mediante el acceso a empleos de calidad en la industria para 
que las empresas sean más productivas; la inclusión de las regiones menos favorecidas en el proceso de industrialización, basados en el perfeccionamiento y el desarrollo de técnicas productivas que generen valor agregado; y la atracción de la inversión extranjera hacia un mercado en situación de expansión y una nación con estabilidad política, macroeconómica y social. (de Ollanta, 2013)

El actual gobierno, a través del Ministro de la Producción, el Señor Bruno Giuffra, deberá dar continuidad a dicha política comercial, impulsando la competitividad de las industrias peruanas e implementando herramientas que permitan alcanzar dichos objetivos. Con arreglo a ello, la segunda vicepresidenta Mercedes Aráoz participó en el Foro Industrial, organizado por la Sociedad Nacional de Industrias, en el cual se expuso sobre los retos de nuestro país para competir en el nuevo entorno mundial y el rol de la industria como motor de competitividad y desarrollo. Según se refiere "el Foro Industrial es como un instrumento de propuesta de políticas públicas socialmente beneficiosas. Se trata de un espacio de diálogo abierto y franco entre el sector público, sector privado, trabajadores y academia, cuyo fin es contribuir con propuestas específicas a la agenda nacional de desarrollo" (Sociedad Nacional de Industrias, 2016).

Si esta política de industrialización es sostenible, se podrán crear ramas de producción más sólidas y competitivas, lo que, a su vez, va a generar una óptima incidencia en el comercio nacional e internacional. Claramente, los esfuerzos gubernamentales y privados deben dirigirse a repotenciar factores, tales como la tecnología, la innovación, la productividad y la capacitación, coadyuvando a la obtención de un resultado positivo en la Balanza Comercial y, consecuentemente, en la Balanza de Cuenta Corriente.

\subsubsection{DESDE LA PERSPECTIVA DE LA OMC:}

El tema de elusión de derechos antidumping ha sido discutido y negociado durante la Ronda de Uruguay; al respecto 123 países intentaron llegar a un acuerdo, sin embargo. los intereses se polarizaron: por un lado, la Unión Europea y Estados Unidos sostenían una posición rigurosa, exigiendo regular en contra de las prácticas elusivas y, por otro lado, los 
países asiáticos consideraban que no se requería incluir, en el GATT y el Acuerdo Antidumping, medidas antielusivas. La polaridad de posiciones y la desaprobación de todo proyecto normativo desembocaron en la falta de consenso.

Esta discusión se extendió en la primera reunión oficial de la Ronda de Doha, el cual se inició en Qatar el pasado noviembre del 2001. En esta Ronda, que aún se encuentra en curso, participan 157 países miembros que tratan de llegar a acuerdos multilaterales que promuevan el libre comercio y otras cuestiones que lo coadyuven.

Para alcanzar los objetivos planteados en el marco de la Ronda, se ha creado un Grupo de Negociación sobre Normas, el cual realiza observaciones y propuestas entorno a las regulaciones antidumping, subvenciones y medidas compensatorias. Este grupo determinó que existían intereses convergentes, por lo que, al no existir una base que ofrezca respuestas, se propuso una redacción jurídica que aborde la problemática. Sin embargo, hasta el momento no se ha arribado a ninguna solución normativa bajo el marco de la OMC.

Recordemos que el tema de la elusión se viene discutiendo desde 1986, con la Ronda de Uruguay, sin embargo, desde entonces no se ha llegado ni siquiera a definir lo que es elusión. Si bien se han creado comisiones y paneles, se han emitido proyectos normativos y se han programado reuniones de negociación, no se ha podido convenir en una decisión.

Siempre será preferible y recomendable que esta problemática sea regulada por la OMC, pues ello va a permitir uniformizar los criterios adscritos a las medidas antielusivas en todos los países miembros, promoviendo la previsibilidad en las decisiones y generando mayor seguridad jurídica y comercial entre naciones, exportadores y productores. Sin embargo, nos atreveríamos a presumir que difícilmente se podrá lograr un resultado a nivel de la OMC, pues cuando varios países participan en negociaciones para alcanzar acuerdos multilaterales, resulta complejo armonizar diversos intereses; prueba de ello es que hasta el momento no se han logrado alcanzar mayores avances.

Bajo esta óptica, mientras la OMC no se pronuncie, se prevé que los países sigan emitiendo normativas unilaterales. Como bien señala "desde la perspectiva doméstica, la 
ausencia de una regulación bajo la OMC, la inclusión de disposiciones antielusivas dentro de la regulación antidumping es legítima siempre que se busque proteger las industrias nacionales del dumping” (Ostoni, 2005, pág. 429).

\subsubsection{DESDE LA PERSPECTIVA DE LOS ACUERDOS COMERCIALES:}

La apertura de mercados internacionales, la globalización y la interconexión entre países impulsó la suscripción de Acuerdos Comerciales ${ }^{50}$.Un Tratado de Libre Comercio es una modalidad de Acuerdo Comercial Internacional y el artículo 2 de la Convención de Viena, sobre el Derecho de los Tratados dispone que:

"Se entiende por "tratado" un acuerdo internacional celebrado por escrito entre Estados y regido por el derecho internacional, ya conste en un instrumento único o en dos o más instrumentos conexos y cualquiera que sea su denominación particular".

Nuestro país tiene acuerdos comerciales bilaterales vigentes con Cuba, Chile, México, Estados Unidos, Canadá, Singapur, China, Corea del Sur, Tailandia, Japón, Panamá, la Unión Europea, Costa Rica y Venezuela. Como parte de las negociaciones, dichos países han discutido, entre otros asuntos, las condiciones de Defensa Comercial, por lo que, se ha regulado respecto a las medidas antidumping. Naturalmente, los acuerdos ya suscritos no comprenden disposiciones antielusivas, pues esta problemática no ha sido materia de discusión en las negociaciones. Sin embargo, cabe precisar que el acápite de Defensa Comercial se limita a remitir su contenido hacia lo dispuesto por el GATT y el Acuerdo Antidumping. Con arreglo a ello, se precisa:

Este tema (barreras no arancelarias) no siempre es tratado de forma específica en los TLC, se establece más bien que cada parte conservará sus derechos y

50 Se define los Acuerdos Comerciales como instrumentos que permiten mejorar el acceso a los mercados de nuestros principales socios comerciales y establecer reglas y disciplinas claras y estables que normen el comercio exterior y que permitan otorgar seguridad a los operadores para mantener e incrementar de manera sostenida sus distintas operaciones" (Ministerio de Comercio Exterior y Turismo, (s.f.)). 
obligaciones de conformidad con las normas de la OMC con respecto a las medidas antidumping. Así los posibles casos sobre dumping deberá ser analizado a la luz del Artículo VI del GATT, Acuerdo Antidumping y la legislación interna de cada país en materia antidumping.

(Miranda, 2005, pág. 40)

Nuestro país se encuentra en una etapa de negociación para la firma de Tratados Comerciales con Turquía y el Salvador, por lo que, en caso se incluya el factor de Defensa Comercial dentro de las discusiones, se recomienda abordar la problemática que implica la elusión. 


\section{CONCLUSIONES}

1. Desde el punto de vista histórico, la Revolución Industrial y el estallido de la Primera y Segundo Guerra Mundial fueron los sucesos que desencadenaron el orden comercial y económico actual, el cual se proyecta en la creación de instituciones como el Fondo Monetario Internacional, el Banco Mundial y la Organización Mundial de Comercio.

2. La normativa internacional que regula las prácticas dumping son el Artículo VI del Acuerdo General sobre Aranceles Aduaneros y Comercio de 1947 y 1994 (GATT) y el Acuerdo Relativo a la aplicación del Artículo VI del Acuerdo General sobre Aranceles y Comercio (Acuerdo Antiduming). Mientras que a nivel nacional esta práctica se reglamenta mediante el Decreto Supremo 006-2003-PCM, modificado por el Decreto Supremo 004-2009-PCM (Reglamento Antidumping).

3. No debe vincularse al dumping con un acto desleal de competencia, ya que ello, implicaría referirse al Derecho de Competencia. Por lo que, concluimos que la forma correcta de definir al dumping es como un acto desleal de comercio internacional, de tal manera, se incide en la existencia de agentes comerciales que participan en un mercado internacional que comprenden dos o más países.

4. Creemos que no es correcto definir al dumping como una práctica predatoria de precios por dos razones: por un lado, según las disposiciones que regulan el dumping, no se toma en cuenta aspectos subjetivos, tal como la intención que impulsaría el accionar del exportador del país extranjero; y, por otro lado, si bien se entiende teóricamente los criterios que envuelven a la práctica predatoria, en la práctica es muy complicado que confluyan los elementos que la comprenden. 
5. Asimismo, reconocemos que el dumping también puede ser definida como una práctica de discriminación internacional de precios, lo que implica que un producto sea vendido a precios distintos en dos zonas geográficas apartadas, siendo los consumidores del país de exportación quienes tengan que pagar un precio mayor por el producto, soportando la discriminación de mercados. Asimismo, especificar el carácter internacional de ésta, la diferencia del Derecho de Competencia, el cual se ajusta a criterios distintos y tiene un alcance netamente nacional.

6. Existe una postura que defiende la configuración de un comercio libre de medidas de defensa comercial, por lo que, se muestran en contra de la aplicación de derechos antidumping. Nosotros creemos que la inclusión de un sistema antidumping es necesario, pues las autoridades competentes tienen la tarea de verificar que las actividades comerciales se realicen de acuerdo a las reglas internacionales, se trata de una labor dirigida a eliminar distorsiones e impulsar una competencia leal.

7. Precisamos que, según prescribe el Acuerdo Antidumping y el Reglamento antidumping, la Comisión de Dumping, Subsidios y Eliminación de Barreras no Arancelarias del INDECOPI, durante el proceso administrativo de investigación, deberá verificar la concurrencia de tres elementos: un margen dumping que supere los criterios de minimis, daño o una amenaza de daño a la rama de producción nacional del país importador y un nexo causal. La verificación de dichos elementos nos permitirá determinar la ejecución de un acto desleal de comercio internacional.

8. Si bien la doctrina ha desarrollado, a un nivel teórico, diversificadas modalidades de dumping, tales como el dumping ocasional, dumping social, dumping ecológico, dumping de elusión, entre otros, ratificamos que éste no es un criterio que será tomado en cuenta por la autoridad administrativa durante el procedimiento de investigación antidumping. Por lo que, la discusión sobre los tipos de dumping tienen un corte netamente teórico.

9. Creemos que es necesario diferenciar el contenido de las prácticas dumping respecto a otras instituciones jurídicas adscritas al Derecho de Competencia y otras 
modalidades de defensa comercial; con arreglo a ello, concluimos que el dumping es diferente al abuso de posición de dominio, del dumping interno y de las salvaguardias.

10. Concluimos que la naturaleza jurídica de los derechos antidumping no es la de un impuesto, pues los elementos que a ésta se le atribuyen no coincide con aquellas. Se entiende que las características que los impuestos comprenden son: la consideración del principio de capacidad contributiva y el principio de legalidad, el ius imperium del Estado para requerir su pago, la facultad de coertio del Estado para captar ingresos que financien sus gastos, entre otros. Mientras que los derechos antidumping comprenden criterios distintos a los antes indicados.

11. Si bien, el Reglamento Antidumping e Informes emitidos por la SUNAT consideran que los derechos antidumping deben tener un trato de multa, consideramos que aquella posición no es tan exacta, pues entendemos que las disposiciones adscritas a una sanción de multa son ilícitas liminarmente, sin embargo, las conductas de elusión no están prohibidas de plano.

12. Nuestra postura respecto a la aplicación de los derechos antidumping se sustenta en la teoría regulatoria del Estado, pues si bien existen Acuerdos Internacionales por los que se han otorgado facultades a la autoridad competente para eliminar las distorsiones existentes en el comercio internacional, las medidas de defensa comercial solo podrán ser aplicadas en la medida que se configuren los elementos exigidos por la normativa internacional y nacional.

13. De acuerdo al análisis de las estadísticas realizadas por la Organización Mundial de Comercio, la razón principal que impulsó el nacimiento en la ejecución de prácticas de elusión fue la creciente aplicación de derechos antidumping, principalmente en países como Estados Unidos y la Unión Europea. Ello fue una de las razones que determinó la configuración de conductas de elusión de derechos antidumping. 
14. Creemos que el incremento en la aplicación de derechos antidumping no responde precisamente al proteccionismo desmedido de ciertos países, como algunas posiciones acusan, sino que se debe a la creciente posición desleal de los agentes comerciales y a la pobre legislación interna de dichos países que sea capaz de reprimir aquellas conductas. Por lo que, entendemos que la elusión es una forma de perpetuar una práctica desleal en el comercio internacional.

15. Consideramos que las fórmulas de elusión que se han configurado comúnmente a nivel internacional han sido las siguientes: la exportación de partes, piezas y componentes para ser ensambladas o completadas en un tercer país o en el país de importación, el traslado de la planta de producción al país de destino, la alteración o modificación menor del producto sujeto a medidas antidumping.

16. Diversos países han emitido normativa elusiva, tal como Estados Unidos, la Unión Europea, Argentina, Colombia, entre otros. Las autoridades competentes de dichos países han aplicado efectivamente las medidas antielusivas y se ha ido desarrollando una, cada vez más creciente, jurisprudencia en torno a las prácticas de elusión. Creemos que toda esta experiencia internacional puede servir de base para desarrollar los criterios en nuestra normativa antielusiva.

17. El único caso que fue materia de un pronunciamiento oficial fue el conflicto entre la Unión Europea y Japón. En el Reporte Final, el Panel del GATT se inhibió de señalar abierta y expresamente la ilegalidad de las medidas antielusivas respecto a la normativa internacional vigente, por ello, consideramos que el GATT no ha prohibido la aplicación de dichas medidas, siendo legítimo que se emita normativa antielusiva a nivel nacional.

18. El Reglamento Antidumping comprende solo un artículo que trata el tema de la elusión, esta disposición hace referencia a solo una fórmula elusiva y no desarrolla un procedimiento específico. Creemos que hay un vacío legal que debe ser abordado, ello dará herramientas a la autoridad administrativa para enfrentar las prácticas que buscan burlar los efectos correctores de los derechos antidumping. 
19. Si bien no existen casos en el Perú que puedan ser catalogados como elusión, pues existe un vacío legal que no permite regular dicha práctica, se han configurado determinados hechos que comparten características comunes con fórmulas de elusión, por ejemplo, tenemos el caso de planchas de yeso, el caso de vasos de polypapel, el caso de tejidos tipo popelina, entre otros. Con arreglo a ello, entendemos que existe casuística que pueda sustentar los propósitos de emitir normativa antielusiva.

20. La Comisión de Dumping, Subsidios y Eliminación de Barreras no Arancelarias realizó una Propuesta de Modificación del Reglamento Antidumping y, aunque estamos de acuerdo con esta medida, opinamos que se deben realizar determinadas especificaciones que mejoren esta propuesta y que limiten la discrecionalidad de la Comisión, generando una mayor certeza en los agentes comerciales para que las decisiones de la autoridad sea más predecible.

21. El hecho de reforzar el sistema antidumping va a permitir que se comercialice en un mercado de leal competencia, lo que podría incidir de forma positiva en la labor de los productores y exportadores nacionales, generando un resultado positivo en la balanza comercial de nuestro país. 


\section{RECOMENDACIONES}

1. En base a los hechos que se han ido configurando en el comercio internacional y en atención a la creciente configuración de prácticas de elusión de derechos antidumping, se propone modificar el Reglamento Antidumping e incluir disposiciones antielusivas. Para ello, podría insertarse una definición de lo que la autoridad entiende por elusión de medidas de protección arancelaria, una cláusula general y diversas fórmulas elusivas que ejemplifiquen la ejecución de esta práctica.

2. Debido a la incertidumbre que podrían generar los términos ambiguos, se recomienda fijar lo que se entiende por "proceso de producción o ensamblaje menor o insignificante", por lo que, se podría tomar en cuenta los criterios desarrollados en la legislación comparada norteamericana para delimitar claramente dicha definición. Según, concuerda Luis Alberto León, Secretario de la Comisión de Dumping, Subsidios y Eliminación de Barreras no Arancelarias y como se establece en el Anexo 6, resulta conveniente la inclusión de parámetro cualitativos.

3. Por su parte, para esclarecer el término "valor significativo", referente a la fórmula de elusión que se realiza mediante la exportación de partes, piezas y componentes a un tercer país o al país de importación, la inclusión de umbrales cuantitativos podría ser recomendable. Para ello, se propone incluir las reglas del $60 \%$ y la del $25 \%$, como bien se establece en la legislación europea y como se determinó en los drafts de la OMC.

4. Teniendo en cuenta que la determinación del producto similar es preponderante para el inicio de una investigación y considerando que un procedimiento antielusivo contiene diversas aristas y es más complejo que un procedimiento antidumping, se sugiere que la determinación del producto similar sea más clara, por lo que, la 
autoridad administrativa debería considerar otros criterios además de la similitud en las características físicas y de uso.

5. El procedimiento de antielusión deberá ser más expedito que el procedimiento antidumping, pues se estaría considerando que en este último ya se determinó la existencia del dumping, daño y nexo causal. Sin embargo, debe tenerse en cuenta que las fórmulas elusivas contienen criterios comunes en algunos casos y disímiles en otros, por lo que, si bien pueden compartir las mismas etapas de investigación, se deberán especificar las condiciones que caractericen a los supuestos de elusión, en la medida que esto proceda.

6. Una de las fuentes normativas que deberá ser considerada para la modificación del Reglamento Antidumping, es la casuística nacional. Los casos que comprenden características que evidenciarían una conducta de elusión han sido variados, al respecto podemos citar el caso de tejidos tipo popelina. Con arreglo a ello, se recomienda la inclusión de la fórmula elusiva conocida en la legislación extranjera como downstream circumvention, la cual no ha sido comprendida en la propuesta normativa.

7. El quehacer de la administración que gira en torno al tema de la presente investigación se concentra en tres instituciones: INDECOPI, MINCETUR y ADANAS. Por lo que, se exhorta a correcta gestión de sus tareas, INDECOPI deberá aplicar las medidas antielusivas de acuerdo a los márgenes establecidos en la ley, MINCETUR se encargará de emitir Resoluciones Ministeriales que determinen el origen no preferencial de los productos materias de dichas medidas y ADUANAS deberá ejecutar dichas Resoluciones y cobrar, en la medida que corresponda, los derechos antidumping eludidos.

8. Son varios países los que han emitido disposiciones antielusivas y las han ejecutado en sus relaciones comerciales, mientras que en nuestro país existe un vacío legal que nos coloca en una situación de desventaja frente otros países. Por ello, se recomienda que el tema de la modificación del Reglamento Antidumping y la 
inclusión de las normas antielusión sean discutidos nuevamente. La elusión de los derechos antidumping deberá ser materia de la agenda del Ministerio de Economía y Finanzas y del Ejecutivo.

9. En el futuro, si se dispone discutir nuevamente sobre la propuesta de modificación del Reglamento Antidumping, sería conveniente considerar la opinión de diversas instituciones que se manifiestan abiertamente interesadas al respecto, tal como COMEX (ver Anexo 3) y la SNI (ver Anexo 4), quienes representan a los importadores $\mathrm{y}$ productores/exportadores nacionales, respectivamente. $\mathrm{La}$ participación de estos grupos y los comentarios que puedan realizar, en razón de sus labores, enriquecerá la propuesta 


\section{REFERENCIAS}

Agencia Peruana de Noticias . (23 de Noviembre de 2013). Perú será sede de la XV Conferencia General de la ONUDI en el año 2013. Andina.

Banco Central de Reservas del Perú. (s.f.). Glosario de términos económicos. Obtenido de http://www.bcrp.gob.pe/publicaciones/glosario/b.html

BCR del Perú. (s.f.). Glosario. Obtenido de Valor Agregado Bruto: http://www.bcrp.gob.pe/publicaciones/glosario/v.html

Barral, W. (2010). Dumping y comercio internacional . Buenos Aires: La Ley.

Basaldúa, R. X. (2007). La Organización Mundial del Comercio y la regulación del comercio internacional. Buenos Aires: Lexis Nexis.

Boletín Oficial del Estado. (1 de Enero de 1986). Tratado constitutivo de la Comunidad Europea del carbón y del acero firmado en París el 18 de abril de 1951. Obtenido de https://www.boe.es/legislacion/enlaces/documentos/ue/Tratados(0397-0475).pdf

Calderón, A. (2011). Perú Económico. Obtenido de Piénsalo otra vez: la sobreprotección contra el dumping : http://perueconomico.com/ediciones/64/articulos/1147

Calmet Mujica, D. (2013). Fiscalización de dumping y subsidios. Lima: INDECOPI.

Carrillo, C. (1996). Lineamientos generales para el análisis del dumping y su efecto en la producción nacional. Themis, 125 - 131.

Chavez Bardales, E. (2009). Regulación contra las prácticas elusivas de los derechos antidumping: necesidad de un consenso multilateral. Ita Ius Esto, 110-138.

Collado Yurrita, M. Á. (2009). Derecho financiero y tributario : parte general . Barcelona: Atelier.

Comunidad Andina de Naciones. (s.f.). Somos Comunidad Andina. Obtenido de ¿Qué es la CAN?: http://www.comunidadandina.org/Seccion.aspx?tipo=QU

CVCE. (11 de Mayo de 2012). Final Act of the Bretton Woods Conference . Obtenido de http://www.cvce.eu/content/publication/2003/12/12/2520351c-0e91-4399-af6369e4b33ef17a/publishable_en.pdf 
Douglas A., I. (1 de Noviembre de 2004). The Smoot-Hawley Tariff: A Quantitative Assessment. Obtenido de Jstor: http://www.dartmouth.edu/ dirwin/docs/smootrestat.pdf

El Comercio. (8 de agosto de 2016). Confecciones y textiles caen y ponen en riesgo $400 \mathrm{mil}$ empleos. Diario El Comercio.

Estudios Económicos de COMEXPERU. (2013). Sobre Gamarra ... ¿En qué quedamos? Negocios internacionales, 26-27.

EURLEX. (20 de Agosto de 2010). Access to European Union law. Obtenido de http://eurlex.europa.eu/legal-content/ES/ALL/?uri=uriserv:OJ.L_.2010.219.01.0001.01.SPA

Fondo Monetario Internacional. (30 de Abril de 2015). El FMI: datos básicos. Obtenido de http://www.imf.org/external/np/exr/facts/spa/glances.htm

García Bueno, M. C. (2009). El principio de capacidad contributiva. En D. Yacolca Estares, Derecho tributario : aspectos constitucionales, generales, informático, procesal, arbitral, internacional, ambiental, minero, construcción, penal y aduanero. Lima: Grijley : Academia Internacional de Derecho Tributario.

Gestión. (13 de noviembre de 2014). SNI pide al Gobierno revisar a profundidad efectos de reducción de aranceles. Gestión.

INDECOPI (12 de diciembre de 2011). Proyecto de modificación del Decreto Supremo $N^{\circ}$ 006-2003-PCM, que reglamenta normas previstas en el "Acuerdo Relativo a la aplicación del artículo VI del Acuerdo General sobre Aranceles Aduaneros y Comercio de 1994", el "Acuerdo sobre Subvenciones y Medidas Compensatorias" y el "Acuerdo sobre Agricultura". Presentación ante la Comisión de Comercio Exterior y Turismo del Congreso de la República. Recuperado el 05 de abril, 2016, dehttp://www2.congreso.gob.pe/sicr/comisiones/2011/com2011comexttur.nsf//pubs foto/69AB42BC0B70DCD60525798200634E69/\$FILE/PRESENTACI\%C3\%93N_ INDECOPI_(12-12-11).PDF.

INDECOPI. (Diciembre de 2014). Informe de Labores 2013. Obtenido de Comisión de Fiscalización de A Dumping y Subsidios: https://www.indecopi.gob.pe/documents/51763/207639/2.Memoria+CFD+2013+final.pdf/5e59e1f8-6356-44e3-9f14-a72a74a211cc

INDECOPI. (2014). Informes Laborales. Obtenido de https://www.indecopi.gob.pe/documents/51763/207639/1.InformeLabores2014.pdf/0540c572-6862-4113-8d87-d7edb705a7 
INDECOPI. (s.f.). Preguntas frecuentes . Obtenido de https://www.indecopi.gob.pe/web/fiscalizacion-dumping-y-subsidios/preguntasfrecuentes

INDECOPI. (s.f.). Procedimiento por prácticas de dumping o subvenciones. Obtenido de https://www.indecopi.gob.pe/web/fiscalizacion-dumping-ysubsidios/procedimiento-sobre-practicas-de-dumping-o-subvenciones

Informativo Caballero Bustamante . (1997). Dumping. Informativo Caballero Bustamante, $\mathrm{H} 1$ - $\mathrm{H} 2$.

Informativo Caballero Bustamante . (s.f.). Naturaleza Jurídica de los Derechos Antidumping $y$ su Tratamiento Tributario. Obtenido de http://www.caballerobustamante.com.pe/plantilla/2012/Naturaleza-Juridica-de-losDerechos-Antidumping.pdf

Lossio, J. (Productor general), (2 de diciembre de 2013). TV Noticias [Emisión televisiva]. Lima: TV Perú - Canal 7

MEF. (s.f.). Política económica y social. Obtenido de ¿Qué es el Producto Bruto Interno?: https://www.mef.gob.pe/es/politica-economica-y-social-sp-2822/23-conceptosbasicos/61-conoce-los-conceptos-basicos-para-comprender-la-economia-del-pais

Ministerio de Comercio Exterior y Turismo. (s.f.). Acuerdos comerciales. Obtenido de http://ww2.mincetur.gob.pe/comercio-exterior/acuerdos-comerciales/

Ministerio de Economía y Finanzas. (8 de Octubre de 2016). Balanza de pagos. Obtenido de http://www.mef.gob.pe/es/?option=com_content\&view=article\&id=52

Miranda, L. G. (2005). Exportadores peruanos : ¿están suficientemente informados y preparados para enfrentar denuncias por dumping? Revista peruana de derecho de la empresa, 35 - 47.

Morón Urbina, J. C. (2015). Comentarios a la Ley del Procedimiento Administrativo General : incluye comentarios a la Ley del Silencio Administrativo . Lima: Gaceta Jurídica.

Olsson, H. (1999). Circumvention of EC antidumping measures. Obtenido de Faculty of law Lund

University: http://lup.lub.lu.se/luur/download?func=downloadFile\&recordOId=1560968\&fileOI $\mathrm{d}=1565483$

Organización Mundial de Comercio. (15 de Abril de 1994). Acuerdo de la Ronda de Uruguay. Obtenido de Declaración de Marrakech : https://www.wto.org/spanish/docs_s/legal_s/marrakesh_decl_s.htm 
Organización Mundial de Comercio. (15 de Abril de 1994). Acuerdo por el que se establece la Organización Mundial de Comercio. Obtenido de https://www.wto.org/spanish/docs_s/legal_s/04-wto.pdf

OMC (1994). Decisión sobre las medidas contra la elusión. Obtenido de https://www.wto.org/spanish/docs_s/legal_s/39-dadp1.pdf

OMC. (1 de Enero de 1995). Entender la OMC. Obtenido de Lo que propugnamos: https://www.wto.org/spanish/thewto_s/whatis_s/what_stand_for_s.htm

Organización Mundial de Comercio. (5 de Febrero de 1998). Noticias: Comunicados de prensa 1998. Obtenido de Cincuentario del sistema multilateral de Comercio: https://www.wto.org/spanish/news_s/pres98_s/pr088_s.htm

Organización Mundial de Comercio. (s.f.). El GATT de 1947 y el GATT de 1994: ¿cuál es la diferencia? Obtenido de https://www.wto.org/spanish/docs_s/legal_s/legalexplgatt1947_s.htm

Organización Mundial de Comercio . (2003). Conferencia ministerial de la OMC, Cancún 2003: notas informativas. Obtenido de Dicho llanamente ... Guia informal de la jerga de la OMC: https://www.wto.org/spanish/thewto_s/minist_s/min03_s/brief_s/brief25_s.htm

Organización Mundial de Comercio . (26 de Noviembre de 2004). Solución de diferencias: Diferencia DS136. Obtenido de Estados Unidos - Ley Antidumping de 1916: https://www.wto.org/spanish/tratop_s/dispu_s/cases_s/ds136_s.htm

Ostoni, L. (2005). Anti-dumping circumvention in the EU and the US: is there a future for multilateral provisions under the WTO? Fordham Journal of Corporate \& Financial Law, 407-438.

PROMPERÚ. (s.f.). Reglas de origen. Obtenido de http://export.promperu.gob.pe/Miercoles/Portal/MME/descargar.aspx archivo=254 00C7B-1B4F-48BE-8441-E302FB0E2AB1.PDF

Resolución 0109-2004-TDC-INDECOPI

Resolución 0293-2015/SDC-INDECOPI

Resolución 052-2002/CDS-INDECOPI

Sierralta Ríos, A. (2001). Palabras liminares del Derecho Internacional del Comercio . Derecho \& Sociedad, 183-206.

Sierralta Ríos, A. (2007). Contratos de Comercio Internacional. Lima: PUCP. 
Sierralta Ríos, A. (2014). Comercio internacional : dumping - subvenciones salvaguardas. Medellín: Universidad de Medellín.

Sociedad Nacional de Industrias. (2016). Foro Industrial. Obtenido de Retomemos el crecimiento: http://www.sni.org.pe/?page_id=6302

Sotomayor Vértiz, A. (2003). Normas antdumping y antitrust en los procesos de integración. Lima: PUCP.

SUNAT. (2007). INFORME $N^{\circ}$ 026-2007-SUNAT/2B0000. Lima.

Tosi, J. L. (2011). Diccionario aduanero: legislación comparada. Florida: Valleta.

U.S. Department of State. (20 de Enero de 2009). The Bretton Woods Conference, 1944. Obtenido de https://2001-2009.state.gov/r/pa/ho/time/wwii/98681.htm

Vega Billán, R. (1999). Aspectos fundamentales del derecho tributario . Lima: Gráfica Horizonte.

Yanning, Y. (2008). Circumvention and anti-circumvention measures: the impact on antidumping practice in international trade. Netherlands: Wolters Kluwer.

Zacnich, R. (2013). ¿Qué se juega el Perú con un proceso antidumping como este? . Negocios internacionales, 12-15. 


\section{BIBLIOGRAFÍA}

Acuerdo General sobre Aranceles Aduaneros y Comercio 1947

Acuerdo General sobre Aranceles Aduaneros y Comercio 1994

Acuerdo Relativo a la aplicación del Artículo VI del Acuerdo General sobre Aranceles Aduaneros y Comercio

Decisión 456, Normas para prevenir las distorsiones en la competencia generadas por prácticas de dumping en importaciones de productos originario de países miembros de la Comunidad Andina.

Decreto Supremo $\mathrm{N}^{\circ}$ 005-2011-MINCETUR que establece marco normativo para la declaración y control del origen de las mercancías sujetas a medidas de defensa comercial.

Decreto Supremo N 006-2003-PCM, modificado por el Decreto Supremo N 004-2009PCM que Reglamentan normas previstas en el "Acuerdo Relativo a la Aplicación del Artículo VI del Acuerdo General sobre Aranceles Aduaneros y Comercio de 1994", el "Acuerdo sobre Subvenciones y Medidas Compensatorias" y en el

"Acuerdo sobre Agricultura

Decreto Supremo $\mathrm{N}^{\circ}$ 133-91-EF, modificado por el Decreto Supremo N 051-92-EF que establecen normas para evitar y corregir las distorsiones de la competencia en el mercado generadas por el "dumping" y los subsidios

Decreto $\mathrm{N}^{\circ}$ 1393/2008 Normas Reglamentarias y de implementación destinadas a la efectiva aplicación de la Ley $\mathrm{N}^{\circ} 24.435$ de Argentina

Decreto $\mathrm{N}^{\circ} 2550$ por el cual se regula la aplicación de derechos antidumping de Colombia

Ley 27444 Ley de Procedimientos Administrativos Generales

Resolución 012-2003/CDS-INDECOPI 
Resolución $N^{\circ}$ 017-2004/CDS-INDECOPI

Resolución $N^{\circ}$ 033-2002/CDS-INDECOPI

Resolución N 038-2011/CFD-INDECOPI

Resolución $\mathrm{N}^{\circ}$ 051-2002/CDS-INDECOPI

Resolución 064-2003/CDS-INDECOPI

Reglamento (CE) $N^{\circ}$ 1225/2009, modificado por el Reglamento (CE) $N^{\circ}$ 1168/2012 del Parlamento Europeo y del Consejo de la Unión Europea

Resolución $\mathrm{N}^{\circ}$ 136-2014/CFD-INDECOPI

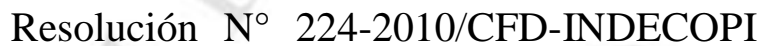

Resolución N² 283-2013/CFD-INDECOPI\}

1677 j Prevención de elusión de las medidas antidumping de Estados Unidos
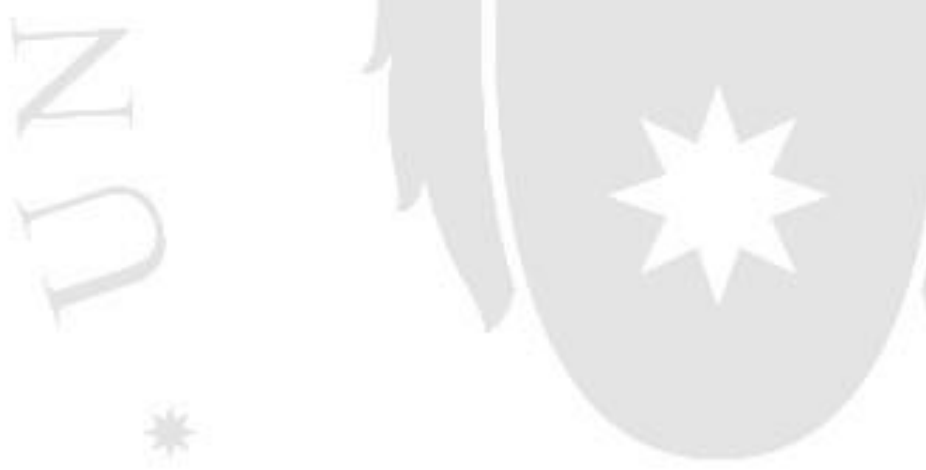


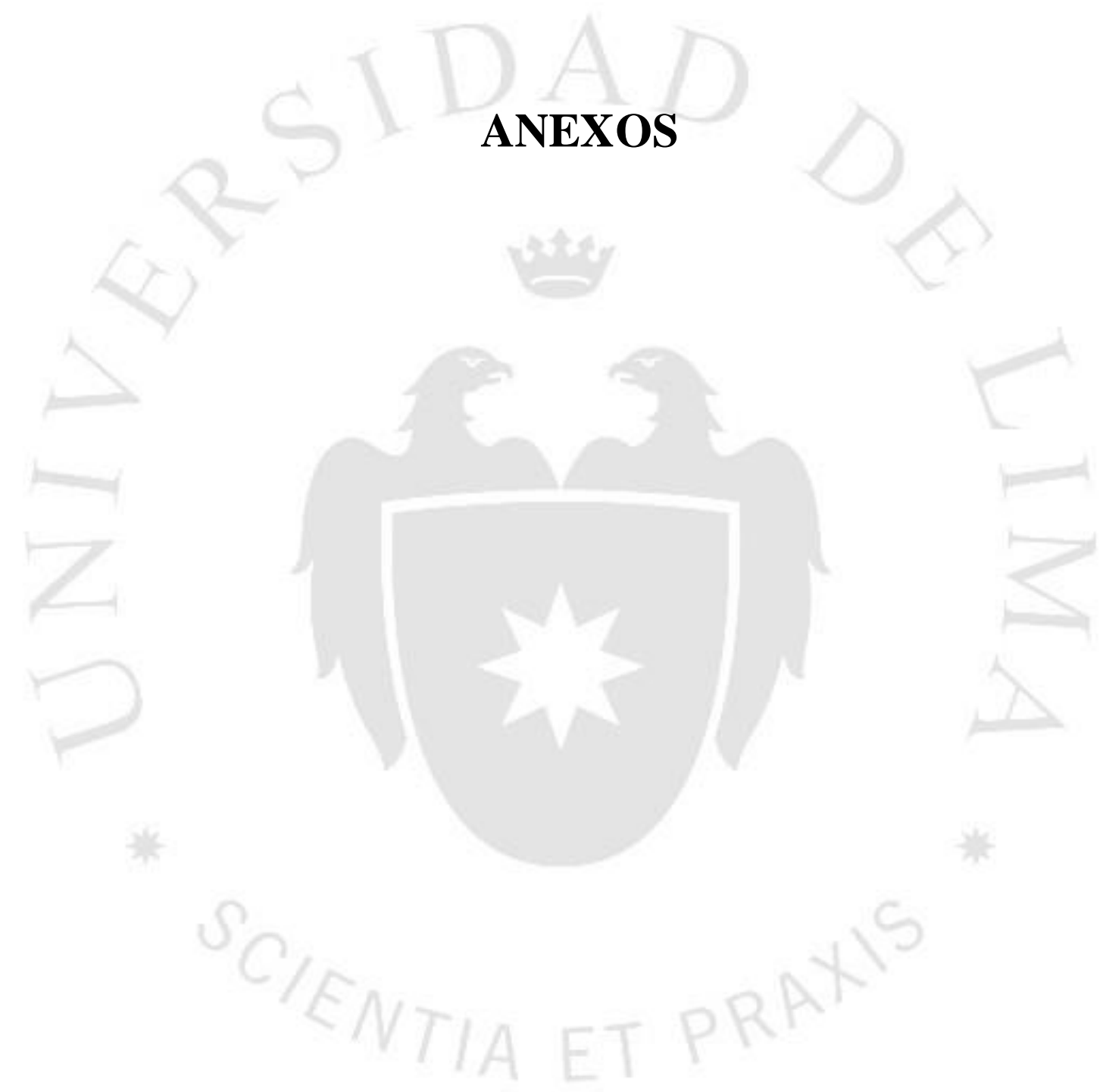




\begin{abstract}
$\operatorname{ANEXON} \mathbf{N}^{\circ} 1$
PROYECTO DE MODIFICACIÓN DEL DECRETO SUPREMO Nº 006-2003-PCM, QUE REGLAMENTA NORMAS PREVISTAS EN EL ACUERDO ANTIDUMPING
\end{abstract}

\title{
Artículo 1.- Sustitución del artículo 58 del Decreto Supremo $\mathbf{N}^{\circ}$ 006-2003-PCM
}

Sustitúyase el artículo 58 del Decreto Supremo N 006-2003-PCM, el cual queda redactado en los siguientes términos:

\section{Artículo 58-A.- Procedimiento Antielusión. Alcances y modalidades de elusión}

La Comisión podrá ampliar la aplicación de los derechos antidumping o compensatorios sobre las importaciones de productos que tengan las mismas características físicas y usos que el producto sujeto a derechos definitivos, procedentes del país de origen investigado o de un tercer país o territorio aduanero, o a partes de esos productos, cuando exista elusión de los derechos.

De manera enunciativa, las modalidades de elusión pueden consistir en:

1. La importación de insumos, piezas, partes o componentes de un producto sujeto a derechos antidumping o compensatorios con el objeto de producir, ensamblar o acabar el producto en el Perú. En este caso se verificará que:

a. Los insumos, piezas, partes o componentes proceden del país o territorio aduanero sujeto a derechos antidumping o compensatorios;

b. Los insumos, piezas, partes o componentes son utilizados para producir, ensamblar o acabar un producto que tiene las mismas características físicas y usos que el producto sujeto a derechos antidumping o compensatorios;

c. El proceso de producción, ensamblaje o acabado realizado en el Perú es menor o insignificante; $y$, 
d. Los insumos, piezas, partes o componentes importados tienen un valor significativo respecto del valor total del producto final.

2. La importación de un producto que haya sido producido, ensamblado o acabado en un tercer país o territorio aduanero con insumos, piezas, partes o componentes originarios del país o territorio aduanero sujeto a derechos antidumping o compensatorios. En este caso se verificará que:

a. El producto producido, ensamblado o acabado en el tercer país o territorio aduanero tiene las mismas características físicas y usos que el producto sujeto a derechos antidumping o compensatorios;

b. El proceso de producción, ensamblaje o acabado realizado en el tercer país o territorio aduanero es menor o insignificante; $y$,

c. Los insumos, piezas, partes o componentes originarios del país o territorio aduanero sujeto a derechos antidumping o compensatorios tienen un valor significativo respecto del valor total del producto producido, ensamblado o acabado en el tercer país o territorio aduanero.

3. La importación del producto sujeto a derechos antidumping o compensatorios con modificaciones o alteraciones menores que no impliquen un cambio en sus características esenciales, aun cuando el producto importado ingrese al Perú a través de una partida arancelaria distinta. En este caso se podrán evaluar los siguientes factores:

a. Características físicas;

b. Expectativas de los compradores;

c. Usos finales;

d. Canales de comercialización;

e. Intercambiabilidad de los productos;

f. Procesos productivos;

g. Diferencias en los costos de producción;

h. Costos de transformación del producto con modificaciones o alteraciones; 
4. La reorganización de los canales de importación con la finalidad de que el producto sujeto a derechos antidumping o compensatorios sea exportado al Perú a través de productores o exportadores beneficiados con un tipo de derecho individual inferior al que le resulta aplicable, o a los cuales no se les haya aplicado un derecho;

5. La importación del producto sujeto a derechos antidumping o compensatorios sin que se haya acreditado conforme a la normativa de la materia, que dicho producto tiene un origen distinto al del país o territorio aduanero de las importaciones afectas a derechos;

6. La importación del producto sujeto a un derecho antidumping o compensatorio que haya sido sometido a un proceso posterior de desarrollo luego de la aplicación del derecho. En este caso se verificará que el producto desarrollado posteriormente:

a. comparta características físicas y usos similares que el producto sujeto a derechos, aun cuando ingrese al Perú a través de una partida arancelaria distinta a la considerada en la investigación; $y$,

b. permita al comprador ejecutar las mismas funciones que el producto sujeto a derechos. Cuando permita ejecutar funciones adicionales, éstas no deben constituir el uso primario del producto desarrollado posteriormente y el costo de tales funciones adicionales no debe representar más que una proporción significativa del costo total de producción.

7. Cualquier otra conducta que implique un cambio en las características del comercio entre terceros países y el Perú o entre empresas individuales del país sujeto a los derechos vigentes y el Perú, derivado de una práctica, proceso o trabajo para el que no exista una causa o justificación económica adecuada distinta del establecimiento del derecho antidumping o compensatorio. En estos casos, debe establecerse que la conducta tiene una repercusión negativa sobre los efectos correctores de los derechos en lo que respecta a los precios y las cantidades del producto similar importado, y que existe dumping en relación con el valor normal establecido en la investigación original en que se impusieron los derechos que se pretende eludir. 


\section{Artículo 58-B.- Disposiciones procedimentales}

El procedimiento de investigación por presuntas prácticas de elusión se iniciará de oficio o a pedido de parte con legítimo interés. En cualquier caso, la Comisión dispondrá el inicio del procedimiento, mediante Resolución motivada, cuando cuente con elementos de prueba suficientes sobre la presunta práctica de elusión.

En la Resolución de inicio del procedimiento de investigación se dispondrá que la autoridad aduanera, en tanto dure la investigación, exija a los importadores del producto investigado, para que proceda el retiro de sus mercancías, el otorgamiento de carta fianza bancaria como garantía de pago de los derechos antidumping o compensatorios que finalmente se determinen.

La Resolución de inicio del procedimiento de investigación, además de ser publicada en el diario oficial "El Peruano" por una (1) sola vez, será notificada a los importadores y exportadores de los productos investigados que hayan sido identificados por la Comisión mediante fuentes públicas de información; a los productores locales supuestamente afectados con tales importaciones; y al Gobierno del país exportador.

Antes o durante el curso de la investigación, la Comisión podrá requerir a Aduanas información sobre el volumen, el valor y el origen de las importaciones de los productos que presuntamente eluden los derechos vigentes.

En el procedimiento se observarán los siguientes plazos:

a. El periodo probatorio del procedimiento será de tres (3) meses contados desde la publicación de la Resolución que dispone su inicio. Dentro del periodo probatorio, la Comisión podrá convocar a una audiencia, a solicitud de parte interesada.

b. Dentro de los treinta (30) días calendario de concluido el periodo probatorio, la Comisión emitirá el documento de los Hechos Esenciales que servirán de base 
para su resolución final, el mismo que deberá ser notificado a las partes apersonadas al procedimiento en el plazo de cinco (5) días hábiles. Las partes podrán presentar sus comentarios a los Hechos Esenciales en un plazo no mayor de siete (7) días hábiles contados a partir del día siguiente de su notificación.

c. Vencido el plazo para la recepción de los comentarios a los Hechos Esenciales, la Comisión resolverá de manera definitiva en el término de quince (15) días.

d. El procedimiento será concluido en un plazo máximo de siete (7) meses, contado a partir de la publicación en el diario oficial "El Peruano" de la Resolución que dispuso su inicio.

En caso la Comisión determine la existencia de elusión y amplíe la aplicación de los derechos correspondientes, dicha decisión surtirá efectos a partir de la fecha en que se hubiesen exigido las garantías. En caso en que la Comisión no determine la existencia de elusión, ordenará la liberación de las garantías otorgadas por los importadores.

Contra la Resolución final que emita la Comisión únicamente podrá interponerse recurso de apelación dentro del plazo de quince (15) días hábiles contados desde la notificación o publicación de la misma, según corresponda. En ese caso, la Comisión elevará el expediente al Tribunal en el plazo máximo de diez (10) días calendarios. El Tribunal resolverá el recurso de apelación en un plazo máximo de cuatro (4) meses.

El procedimiento antielusión se regirá supletoriamente por las disposiciones establecidas en los Artículos 25 a 57 del presente Reglamento, en lo que resulten aplicables. 


\begin{abstract}
$\operatorname{ANEXON} \mathbf{N}^{\circ}$
\end{abstract}
EXPosición de Motivos DEL ProyeCto de ModifiCACión DEL DeCRETo SuPREMo N ${ }^{\circ}$

006-2003-PCM

\title{
1. INTRODUCCIÓN:
}

El Decreto Supremo No 006-2003-PCM, modificado por el Decreto Supremo No 004-2009PCM (en adelante, el Reglamento) ${ }^{1}$ es la norma que reglamenta en el Perú el Acuerdo Relativo a la Aplicación del Artículo VI del Acuerdo General sobre Aranceles Aduaneros y Comercio - GATT de 1994 (en adelante, el Acuerdo Antidumping) y el Acuerdo sobre Subvenciones y Medidas Compensatorias (en adelante, el Acuerdo sobre Subvenciones) de la Organización Mundial del Comercio (OMC).

Desde su entrada en vigencia en el año 2003, el Reglamento se ha constituido como una herramienta legal efectiva para combatir el dumping y las subvenciones que generan distorsiones en el mercado nacional. Al amparo de dicha norma y de los Acuerdos de la OMC, la Comisión de Fiscalización de Dumping y Subsidios del INDECOPI (en adelante, la Comisión) ha desarrollado investigaciones y aplicado derechos antidumping y medidas compensatorias a una diversidad de productos importados subsidiados y a precios dumping, garantizando de esa manera que exista un equilibrio en las condiciones de competencia entre los productores nacionales y las importaciones.

No obstante, el Reglamento contiene disposiciones que requieren ser mejoradas con la finalidad de asegurar una competencia leal dentro del mercado nacional, tales como las referidas a las prácticas de elusión en el pago de los derechos antidumping y compensatorios. En efecto, pese a que el propio Reglamento reconoce que los derechos

\footnotetext{
${ }^{1}$ El Decreto Supremo No 006-2003-PCM fue publicado en el diario oficial "El Peruano" el 11 de enero de 2003 y entró en vigencia al día siguiente de su publicación.
} 
antidumping y compensatorios son medidas destinadas a corregir las distorsiones generadas en el mercado por las prácticas de dumping y las subvenciones, carece de disposiciones que permitan afrontar, de una manera integral, la problemática de las prácticas elusorias de derechos, los cuales conllevan a un menoscabo de los efectos correctores de los mismos.

En efecto, el Reglamento vigente sólo contempla una modalidad de elusión e ignora una serie de otras prácticas elusorias que se verifican con mayor frecuencia en la realidad. A ello cabe agregar que para utilizar dicho mecanismo debe iniciarse un procedimiento que se rige por las mismas disposiciones aplicables a las investigaciones por dumping y por subvenciones, cuyos plazos y requisitos giran en función a la materia controvertida en dichas investigaciones (es decir, determinación de la existencia de dumping o subvenciones que causan un daño importante a la rama de producción nacional). No obstante, dada la naturaleza y fines del procedimiento antielusión (evitar que se menoscaben o anulen los efectos correctores de derechos antidumping o compensatorios previamente determinados por la Comisión), no resulta razonable que le sean aplicables los mismos plazos y formalidades previstas para las investigaciones por dumping y subvenciones.

Estas deficiencias del Reglamento vigente limitan la actuación de la autoridad administrativa para enfrentar eficazmente las prácticas elusorias que se producen en el mercado y pueden significar un desincentivo para que los productores locales denuncien tales prácticas y puedan adoptarse las acciones correctivas que correspondan.

En contraste a esta situación, a nivel internacional, diversos países miembros de la OMC (entre ellos, países de la región) cuentan con normativa que regula de manera exhaustiva las prácticas de elusión de los derechos antidumping y compensatorios vigentes en sus mercados. Así, los Estados, Unidos de América, la Unión Europea, México, Colombia, Argentina, Uruguay y Brasil, entre otros, han incorporado a sus legislaciones, desde hace varios años atrás, disposiciones para combatir las prácticas de elusión que afectan sus mercados locales. Incluso, a nivel subregional, la Comunidad Andina de Naciones también posee una regulación especial sobre las prácticas y los procedimientos aplicables para combatir la elusión de derechos antidumping y compensatorios. 
Es pertinente indicar que varios de los países antes mencionados son actualmente socios comerciales del Perú, pues en el último quinquenio se ha celebrado con ellos diversos acuerdos de comercio para ampliar mercados. Como consecuencia de tales acuerdos se espera que aumenten los flujos comerciales, con el consiguiente beneficio que ello generará para el país; sin embargo, no debe descartarse que este incremento de los flujos comerciales pueda generar la aparición de prácticas desleales en las importaciones que afecten el buen funcionamiento de los mercados internos. En este contexto, constituye una necesidad que el Reglamento incorpore normas que permitan investigar las prácticas elusorias en todas sus manifestaciones, pues de esa forma se contribuirá a lograr un equilibrio en el comercio del Perú y sus socios comerciales.

Con tal finalidad, la Comisión, como autoridad nacional encargada de investigar y dictar las medidas pertinentes para corregir las distorsiones que generan las prácticas de dumping y de subvenciones en el mercado nacional, ha preparado una propuesta normativa para incorporar al Reglamento nacional, un conjunto de disposiciones para regular, de manera integral, la problemática de las prácticas elusorias de derechos antidumping y compensatorios, tomando como base la experiencia adquirida en la aplicación de los instrumentos de defensa comercial en el Perú, así como los más destacados referentes a nivel internacional.

\section{Fundamento de la Propuesta:}

De conformidad con lo establecido en el Acuerdo Antidumping y en el Acuerdo sobre Subvenciones de la OMC, luego de haber seguido el respectivo procedimiento de investigación, las autoridades investigadoras del país Miembro importador podrán establecer derechos antidumping o compensatorios a las importaciones de aquellos productos que hayan sido materia de investigación, siempre que se haya comprobado la existencia de: (i) una práctica de dumping o un subsidio específico otorgado por el gobierno del país exportador; (ii) un daño sufrido por una rama de producción nacional; y, (iii) una relación causal entre la práctica de dumping o la subvención y el daño sufrido por la rama de producción nacional. 
Los mencionados derechos tienen por finalidad corregir las distorsiones del mercado del país Miembro importador generadas por las prácticas de dumping y las subvenciones. Sin embargo, para los exportadores extranjeros de los productos afectos y los importadores de tales productos, la imposición de estos derechos representa una carga económica que hace "menos atractiva" su oferta, razón por la cual algunos de estos exportadores e importadores recurren a prácticas de elusión ${ }^{2}$ con la finalidad de evitar el pago de los mencionados derechos y, de esa manera, recuperar la "competitividad" de su oferta exportadora.

Si bien el Acuerdo Antidumping y el Acuerdo sobre Subvenciones no regulan este tipo de prácticas de elusión, cabe indicar que durante las negociaciones de la Ronda de Uruguay los Miembros de la OMC acordaron lo siguiente:

"Tomando nota de que, aun cuando el problema de la elusión de los derechos antidumping ha sido uno de los temas tratados en las negociaciones que han precedido al Acuerdo relativo a la Aplicación del Artículo VI del GATT de 1994, los negociadores no han podido llegar a un acuerdo sobre un texto concreto,

Conscientes de la conveniencia de que puedan aplicarse normas uniformes en esta esfera lo más pronto posible,

Deciden remitir la cuestión, para su resolución, al Comité de Prácticas Antidumping establecido en virtud de dicho Acuerdo."

Tres años después de aprobado el Acuerdo Antidumping, el Comité de Prácticas Antidumping de la OMC estableció un Grupo Informal sobre Elusión, al cual encargó la tarea de promover la discusión y el debate sobre dicha materia entre los países Miembros

\footnotetext{
${ }^{2}$ Yanning Yu en "Circumvention and Anti-Circumvention Measures. The Impact on Antidumping practices in the International Trade". Página 24. Publicado por Klawer Law International en 2008.

Traducción libre del siguiente texto:

"Broadly defined, circumvention refers to all practices that evade or do not pay anti-dumping duties, in a manner that undermines the purpose and effectiveness of anti-dumping measures imposed by the importing country."
} 
de la referida organización. No obstante, a la fecha, pese a las negociaciones efectuadas en el marco de dicho grupo, no se ha arribado a un acuerdo multilateral sobre la materia ${ }^{3}$.

En ese contexto, y ante la inexistencia de disposiciones de alcance multilateral que regulen las prácticas de elusión del pago de los derechos antidumping o compensatorios, algunos países Miembros de la OMC (entre ellos, países de la región) como los Estados Unidos de Norteamérica (en adelante, EE.UU.) ${ }^{4}$, la Unión Europea (en adelante, la UE) ${ }^{5}$, los Estados Unidos Mexicanos (en adelante, México) ${ }^{6}$, la República Argentina (en adelante, Argentina $^{7}$, la República Oriental del Uruguay (en adelante, Uruguay) ${ }^{8}$; la República de Colombia (en adelante, Colombia) ${ }^{9}$, entre otros, han optado por afrontar la problemática de la elusión de derechos a través de su marco normativo interno. Incluso, a nivel subregional, la Comunidad Andina de Naciones (en adelante, CAN) no ha sido ajena a esta problemática y ha incluido disposiciones antielusión en las Decisiones 456 y 457 que datan de $1999^{10}$.

Cabe señalar que los países anteriormente mencionados han estructurado las normas antielusión de manera similar. Así, las legislaciones de esos países contienen una lista

\footnotetext{
${ }^{3}$ Sobre el particular, Van Bael \& Bellis en "Anti-dumping and other Trade Protection Laws of the EC" (Cuarta Edición) señalan lo siguiente:

"To date, a great divergence of opinion remains as to what constitutes circumvention and when anticircumvention measures may be applied." Página 482

${ }^{4}$ Las disposiciones que regulan las prácticas de elusión de derechos antidumping y compensatorios dentro del marco normativo de los EEUU se encuentran contenidas en la Tariff Act 781, 19 U.S.C. 1677j.

${ }^{5}$ Las disposiciones que regulan las prácticas de elusión de derechos dentro del marco normativo de la UE se
} encuentran contenidas en el Reglamento (CE) No 1225/2009 Del Consejo.

${ }^{6}$ Las disposiciones que regulan las prácticas de elusión de derechos dentro del marco normativo mexicano se encuentran contenidas en la Ley de Comercio Exterior.

${ }^{7}$ Las disposiciones que regulan las prácticas de elusión de derechos dentro del marco normativo argentino se encuentran contenidas en el Decreto 1393/2008, "Normas reglamentarias y de implementación destinadas a la efectiva aplicación de la Ley $\mathrm{N}^{\circ} 24.425$ ”.

${ }^{8}$ Las disposiciones que regulan las prácticas de elusión de derechos dentro del marco normativo uruguayo se encuentran contenidas en el Decreto 2779/2009, del 5 de febrero de 2010.

${ }^{9}$ Las disposiciones que regulan las prácticas de elusión de derechos dentro del marco normativo colombiano se encuentran contenidas en el Decreto $\mathrm{N}^{\mathrm{o}} 2550$ del 15 de julio de 2010.

${ }^{10}$ Decisión 456: Normas para prevenir o corregir las distorsiones en la competencia generadas por prácticas de dumping en importaciones de productos originarios de Países Miembros de la Comunidad Andina.

Decisión 457: Normas para prevenir o corregir las distorsiones en la competencia generadas por prácticas de subvenciones en importaciones de productos originarios de Países Miembros de la Comunidad Andina. 
enunciativa de las modalidades de elusión e incluyen, por lo general, una "cláusula general" que permite analizar otras modalidades de elusión no consideradas de manera expresa en la norma; así como un procedimiento especial que, en todos los casos, es bastante más expeditivo y breve que los procedimientos de investigación. Es importante mencionar que sólo algunas de las legislaciones revisadas incluyen una definición de la práctica de elusión.

En este punto, cabe resaltar que el Perú tiene celebrados acuerdos comerciales con varias de las economías antes mencionadas, de modo que es previsible que los flujos comerciales aumenten de manera importante en los próximos años, lo que impactará positivamente en las exportaciones de los productos peruanos a mercados de mayor amplitud. Sin embargo, el mayor flujo comercial puede generar también que se produzcan prácticas desleales en las importaciones, o de conductas elusorias que busquen erosionar la aplicación de las medidas de defensa comercial impuestas por la Comisión. Es importante mencionar aquí que, mientras el Perú no cuenta con un marco legal integral que permita enfrentar tales prácticas elusorias, otros países que son socios comerciales del Perú tienen legislaciones vastas y completas sobre esta materia que les permiten actuar en defensa de sus mercados locales, incluso eventualmente frente a exportaciones peruanas.

En tal sentido, conjuntamente con los Acuerdos de la OMC y las normas nacionales que los reglamentan, las normas antielusión constituyen una herramienta efectiva de protección de los mercados frente a las prácticas desleales de comercio que pueden distorsionar las condiciones de competencia entre los productos nacionales y las importaciones.

Por tanto, se hace imperativo que el Perú cuente con normas que permitan afrontar de manera integral la problemática de la elusión, pues de esa manera se podrá contar con una herramienta legal que coadyuve a contrarrestar eficazmente las distorsiones causadas por este tipo de prácticas, garantizando un mayor equilibrio en el proceso de inserción del Perú al comercio mundial.

En el Perú, el artículo 58 del Reglamento regula la facultad de la Comisión para establecer derechos antidumping o compensatorios sobre las importaciones de partes, piezas o 
componentes de productos con los que se pretenda eludir el pago de derechos vigentes sobre los productos terminados:

\section{“Artículo 58.- Aplicación de derechos antidumping o compensatorios sobre la importación de partes piezas o componentes.- La Comisión podrá} aplicar derechos antidumping o compensatorios, provisionales $o$ definitivos, sobre la importación de partes, piezas o componentes provenientes del país de origen del producto final sujeto a derechos definitivos, cuando existan evidencias de que tales importaciones se realizan con la finalidad de eludir la aplicación de derechos antidumping o compensatorios impuestos al producto final. Para tal efecto la Comisión tendrá en cuenta entre otros factores:

a) Si el producto vendido en el Perú hubiera sido montado o terminado en el Perú con partes, piezas o componentes producidos en el país de origen del producto final sujeto a derechos definitivos.

b) Si el producto vendido en el Perú hubiera sido montado o terminado en un tercer país con partes, piezas o componentes producidos en el país de origen del producto final sujeto a derechos definitivos.

c) Si el montaje o terminación hubiera sido efectuada por una parte que está vinculada al exportador o productor del producto final sujeto a derechos definitivos.

d) Si las importaciones de partes, piezas o componentes del producto sujeto a derechos definitivos y las operaciones de ensamble o terminación de dichos productos, han aumentado después de la publicación de la Resolución que da inicio a la investigación.

e) Cualquier otra circunstancia que determine un cambio en las características del comercio, para el que no exista una causa o una justificación económica distinta de la imposición del derecho, y haya pruebas de que se está eludiendo el pago de los derechos definitivos impuestos al producto final. 


\section{El procedimiento de examen se regirá por las disposiciones establecidas en los}

Artículos 21 al 57 del presente Reglamento en lo que resulten aplicables."

Si bien el actual Reglamento incluye una disposición antielusión, el ámbito de aplicación de la misma resulta ciertamente limitado, en la medida que sólo considera una modalidad de elusión (la importación de partes, piezas o componentes del producto afecto a derechos para ser ensambladas y comercializadas en el territorio nacional), a pesar que a nivel internacional, la regulación sobre esta materia alcanza a otra serie de conductas o modalidades que también están orientadas a eludir el pago de los derechos.

En efecto, en la legislación comparada ${ }^{11}$ se contemplan diversas modalidades de elusión de derechos, además de la importación de partes o piezas para su posterior ensamblaje y comercialización. Así, por ejemplo, algunas de las prácticas comerciales más utilizadas para eludir el pago de los derechos vigentes son: (i) importar un producto afecto a derechos con modificaciones menores que no impliquen un cambio en sus características esenciales; (ii) importar un producto similar al que se encuentra afecto a derechos vigentes, que haya sido montado o acabado en un tercer país utilizando partes o piezas del producto afecto; $y$, (iii) la reorganización por los exportadores o productores de sus canales de venta, con el fin de que sus productos sean exportados al país que realizó la investigación a través de productores o exportadores beneficiarios de un tipo de derecho individual inferior al que les resulta aplicable, o a los cuales no se les haya aplicado derechos.

Precisamente, este vacío legal genera que actualmente la Comisión carezca de un marco normativo idóneo que le permita investigar aquellas conductas elusorias distintas a la prevista en el Reglamento ${ }^{12}$.

\footnotetext{
${ }^{11}$ La Unión Europea, Argentina, México y Brasil contienen dentro de sus respectivos marcos normativos no solo una lista enunciativa de modalidades de elusión sino, además, una definición general de dicha práctica, lo cual permite que sus autoridades investigadoras puedan analizar prácticas de elusión distintas a las previstas expresamente en sus listas enunciativas.

${ }^{12}$ A modo de referencia, cabe mencionar el caso de los derechos antidumping impuestos en el año 2004 sobre las importaciones de planchas de yeso con un espesor igual o superior a $12,7 \mathrm{~mm}$ originarias de Chile. En ese caso se observó que luego de que la Comisión dispuso la aplicación de tales derechos, las importaciones de los productos afectos fueron sustituidas por importaciones de planchas de yeso del mismo origen, pero con leves modificaciones (un espesor de 12,5 mm). En la medida que esta modalidad de elusión no está prevista en el Reglamento, por la vía de un procedimiento de reclamo por la falta de pago de derechos iniciado a instancia del productor local, el Tribunal del INDECOPI dispuso que Aduanas efectúe el cobro de los
} 
Por otro lado, en el aspecto procedimental, el marco normativo vigente en materia de elusión carece de un procedimiento especial, acorde con la naturaleza de la práctica comercial a investigar. En efecto, el artículo 58 del Reglamento establece que la aplicación de derechos a las partes, piezas y componentes se producirá a través de un procedimiento regido bajo las mismas disposiciones que son aplicables a las investigaciones por dumping y subvenciones, establecidas en los artículos 21 a 57 del Reglamento. Ello implica que para el análisis de una práctica elusoria bajo la única modalidad regulada en el Reglamento se requiere seguir el mismo procedimiento establecido para las investigaciones por dumping y subvenciones, las cuales duran normalmente doce (12) meses.

Sin embargo, el procedimiento antielusión y las investigaciones por dumping y subvenciones son procedimientos distintos. Así, mientras que en los procedimientos de investigación por dumping y subvenciones se requiere acreditar que el daño sufrido por una rama de producción nacional obedece a la existencia de una práctica de dumping o a una subvención; en un procedimiento por prácticas de elusión de derechos se parte de las constataciones efectuadas en el procedimiento de investigación original (en el que se impusieron los derechos que se pretenden eludir) y únicamente se debe acreditar la existencia de una conducta elusoria de los derechos vigentes. Siendo ello así, es necesario contar con un procedimiento antielusión expeditivo que responda a la necesidad de aplicar con urgencia medidas que eviten la erosión de los derechos aplicados para la protección del mercado nacional.

derechos antidumping a las importaciones de planchas de yeso ligeramente modificadas, aplicando al caso las tolerancias dimensionales establecidas en la norma técnica correspondiente (Resolución N ${ }^{\circ}$ 0539-2005/TDCINDECOPI). Sin embargo, la Corte Suprema de Justicia de la República declaró la nulidad de dicho acto administrativo por considerar que los derechos antidumping habían sido impuestos en su oportunidad bajo parámetros taxativos, por lo que no correspondía ampliar la aplicación de tales derechos sobre productos modificados.

En otro caso del 2007, la Comisión verificó que se habían realizado importaciones de medidores de agua de chorro múltiple (en las medidas de 1/2,3/4 y 1 pulgada) originarios de China, los cuales ingresaron al Perú desarmados con la finalidad de eludir el pago de los derechos antidumping impuestos sobre dichos productos en el año 2002. Debido a que el Reglamento sólo contempla, como modalidad de elusión, la importación de piezas, partes y componentes del producto para su posterior ensamblado en el territorio nacional, este caso tuvo que ser analizado como si se tratase de una incorrecta aplicación por parte de Aduanas de los derechos antidumping impuestos. En dicha oportunidad, la Comisión dispuso la aplicación de derechos antidumping al corroborar que se habían realizado importaciones de medidores de agua desarmados e incompletos, pero con las características de medidores completos con la finalidad de eludir el pago de los derechos. 
En este punto, debe indicarse que la falta de disposiciones adecuadas que regulen las modalidades de elusión más frecuentes, así como el establecimiento de un procedimiento con un plazo de duración similar a las investigaciones por dumping y subvenciones, constituyen deficiencias que limitan la actuación de la autoridad nacional y pueden desincentivar a los productores locales a solicitar el inicio de este tipo de procedimientos cuando adviertan un cambio en el comercio que menoscabe los efectos correctores de los derechos antidumping o compensatorios.

Con la finalidad de corregir esta situación, resulta necesario incluir en el Reglamento disposiciones que aborden de manera integral la problemática de la elusión, tanto en los aspectos sustantivos referidos a la precisa determinación de las modalidades de elusión que serán objeto de medidas correctivas, así como en los aspectos procesales que permitan dotar al mecanismo antielusión de un procedimiento especial, con plazos que sean acordes con la complejidad de la materia a ser discutida en ese caso ${ }^{13}$.

\section{Propuesta de Reforma y Modificación:}

\section{Artículo 58 del Reglamento}

Se propone sustituir el actual artículo 58 del Reglamento por los artículos 58A y 58B. El artículo 58A contendrá los alcances de la norma antielusión y las modalidades de elusión que serán objeto de investigación por parte de la Comisión. Por su parte, el artículo 58B contendrá las disposiciones procedimentales que regirán el trámite del procedimiento antielusión.

\section{$\underline{\text { Artículo 58A }}$}

\footnotetext{
${ }^{13}$ Así, por ejemplo, establecer un periodo probatorio de seis (6) meses, susceptible de ser ampliado por tres (3) meses adicionales - conforme lo dispone el artículo 28 del Reglamento - para una investigación por presuntas prácticas de elusión resulta innecesariamente extenso, debido a que los puntos o cuestiones controvertidos en este tipo de procedimientos no son los mismos, ni tienen la misma complejidad que aquellos que se presentan en un procedimiento de investigación original.
} 
En cuanto al artículo 58A, éste facultará a la Comisión a ampliar la aplicación de los derechos antidumping o compensatorios sobre las importaciones de productos que tienen las mismas características físicas y usos que el producto sujeto a derechos definitivos, procedentes del país de origen investigado o de un tercer país o territorio aduanero, o sobre las partes de estos productos, cuando se verifique la existencia de una práctica de elusión de los derechos definitivos. Como se advierte, la propuesta busca ampliar la aplicación de los derechos sobre un producto que elude el pago de tales derechos. Para ello se verificará si el producto respecto del cual se realiza la investigación antielusión tiene las mismas características físicas y los usos que el producto sujeto a derechos, pues tales criterios son los más relevantes a efectos de determinar el grado de similitud existente entre ambos.

Asimismo, la propuesta normativa regula, como principales modalidades de elusión, las siguientes:

(i) La importación de insumos, piezas, partes o componentes del producto sujeto a derechos antidumping o compensatorios con el objeto de producir, ensamblar o acabar el producto en el Perú

Esta modalidad de elusión está prevista actualmente en el Reglamento, pero limitada a la importación de piezas, partes o componentes del producto afecto a derechos antidumping y compensatorios para ser montados o terminados en el Perú, y eludir así el pago de tales de derechos. En otros países también se regula esta modalidad de elusión, como es el caso de las legislaciones de los Estados Unidos (literal (a) de la Sección 1677j de la Ley de Aranceles de $1930^{14}$ ), la UE (artículo 13.2 del Reglamento (CE) No 1225/2009 del Consejo $^{15}$ ), Argentina (literal (a) del artículo 59 del Decreto 1393/2008 ${ }^{16}$ ), México

\footnotetext{
${ }^{14}$ Las normas en materia de elusión de medidas antidumping y compensatorias se encuentra regulada en la Sección 1677j de la Parte IV (Provisiones Generales) del Subtítulo IV de la Ley de Aranceles de 1930, el cual regula las medidas antidumping y compensatorias.

${ }^{15}$ Reglamento (CE) N $1225 / 2009$ del Consejo del 30 de noviembre de 2009, relativo a la defensa contra las importaciones que sean objeto de dumping por parte de países no miembros de la Comunidad Europea.
} 
(numeral I del artículo 89B de la Ley de Comercio Exterior ${ }^{17}$ ), Colombia (artículo 53 del Decreto $2550^{18}$ ) y la CAN (artículo 75 de la Decisión $456^{19}$ ).

Sobre la aplicación de esta modalidad, es pertinente traer a colación un caso resuelto por la autoridad mexicana en 2008, referido a las importaciones de rollos de tela de tejido de punto de pelo largo tipo raschel estampados. En ese caso se observó que las importaciones del producto afecto con derechos antidumping -cobertores estampados procedentes de China- fueron sustituidas por importaciones de rollos de tela de tejido de punto de pelo largo tipo raschel estampados del mismo origen, los cuales eran sometidos a un proceso de acabado menor en México a efectos de obtener cobertores ${ }^{20}$.

Durante el procedimiento antielusión, la autoridad mexicana comprobó que las empresas importadoras habían sustituido totalmente las importaciones de cobertores estampados afectos al pago de medidas antidumping por los rollos de tela de tejido de punto de pelo largo tipo raschel, los cuales eran sometidos a operaciones relativamente simples y de poco valor agregado en México para obtener un producto similar al afecto con los derechos antidumping $^{21}$. Asimismo, se comprobó el ingreso masivo de los rollos de tela a precios por debajo de los costos de producción mexicana de los cobertores estampados ${ }^{22}$, sin que

${ }^{16}$ Las normas antielusión se encuentran reguladas en el Capítulo IX del Decreto 1393/2008 - Normas reglamentarias y de implementación destinadas a la efectiva aplicación de la Ley $\mathrm{N}^{\circ} 24.425$.

${ }^{17}$ Las normas antielusión se encuentran reguladas en el Capítulo V (Procedimientos Especiales) de la Ley de Comercio Exterior, publicada en el Diario Oficial de la Federación el 27 de julio de 1993.

18 Las normas antielusión se encuentran reguladas en la Sección II del Capítulo V (Establecimiento y percepción de derechos antidumping), Título II (Aplicación de derechos antidumping a países miembros de la Organización Mundial de Comercio) del Decreto 2550 del 15 de julio de 2010, por el cual se regula la aplicación de derechos antidumping.

${ }^{19}$ Las normas antielusión se encuentran reguladas en el Capítulo VIII (Elusión), de la Decisión 456, Normas para prevenir o corregir las distorsiones en la competencia generadas por prácticas de dumping en importaciones de productos originarios de Países Miembros de la Comunidad Andina.

${ }^{20}$ El proceso de acabado consiste en cortar los rollos de tela, colocar una cinta perimetral y etiquetas de identificación para obtener el cobertor terminado.

${ }^{21}$ En la investigación se determinó que las operaciones de acabado para la fabricación de cobertores no requerían montos significativos de inversión en maquinaria o equipos especializados, ni la contratación de personal con conocimientos técnicos para la producción del producto.

${ }^{22}$ Durante la investigación se observó el aumento significativo de importaciones del producto investigado en términos absolutos $(861 \%)$ como en relación con la producción mexicana de cobertores. De manera similar, 
existiese una razón económica que justificase tal actividad. Por el contrario, la autoridad mexicana determinó que resultaba económicamente más atractivo importar los rollos de tela y realizar operaciones menores de acabado que importar los cobertores estampados pagando las medidas antidumping. Por estos motivos, se dispuso que los rollos de tela de tejido de punto de pelo largo tipo raschel estampados procedentes de China queden sujetos al pago del mismo derecho impuesto para los cobertores estampados en la investigación original.

Considerando los referentes de la legislación internacional antes mencionados, y con la finalidad de mejorar la regulación que actualmente existe respecto de esta modalidad, en el proyecto se propone considerar como una práctica de elusión, la importación de insumos, piezas, partes o componentes del país de origen del producto sujeto a derechos con la finalidad de producir, ensamblar o acabar un producto con las mismas características físicas y usos que el producto sujeto a tales derechos. Para ello, de manera similar a lo establecido en la legislación comparada, se precisa los criterios que la Comisión deberá considerar para efectuar su análisis en cada caso ${ }^{23}$.

(ii) La importación de un producto producido, ensamblado o acabado en un tercer país o territorio aduanero con insumos, piezas, partes o componentes originarios del país o territorio aduanero sujeto a derechos

Esta modalidad de elusión está prevista actualmente en el Reglamento, pero limitada a la importación de un producto montado o terminado en un tercer país con piezas, partes o componentes del producto afecto a derechos. En otros países también se regula esta modalidad de elusión, como es el caso de las legislaciones de los Estados Unidos (literal

se observó que el número de cobertores obtenidos a través de los rollos de tela importados aumentó $1713 \%$ en entre 2004 y 2006.

${ }^{23}$ Así, se establece que se debe verificar que los insumos, piezas, partes o componentes: (i) proceden del país o territorio aduanero sujeto a derechos; (ii) sirven para producir, ensamblar o acabar un producto que tiene las mismas características físicas y usos que el producto afecto; $y$, (iii) tienen un valor significativo respecto del valor total del producto final. Asimismo, la autoridad investigadora deberá verificar que el proceso de producción, ensamblaje o acabado realizado en el Perú es menor o insignificante. 
(b) de la Sección 1677j de la Ley de Aranceles de 1930), la UE (artículo 13.2 del Reglamento (CE) No 1225/2009 del Consejo), Argentina (literal (b) del artículo 59 del Decreto 1393/2008), México (numeral II del artículo 89B de la Ley de Comercio Exterior) y Colombia (artículo 53 del Decreto 2550).

Sobre la aplicación de esta modalidad, es pertinente traer a colación un caso resuelto por la autoridad europea en 2008, referido a las importaciones de calzado con parte superior de cuero. En ese caso se observó que las importaciones del producto afecto con derechos antidumping - calzado con parte superior de cuero originario de $\mathrm{China}^{24}-$ fueron sustituidas por importaciones del mismo producto procedente de $\mathrm{Macao}^{25}$.

Durante el procedimiento antielusión, la autoridad europea comprobó que, luego de la imposición de las medidas, las importaciones de calzado chino afectos a tales medidas disminuyeron, mientras que las importaciones del mismo producto procedente de Macao aumentaron significativamente, pese a que el nivel de producción de calzado en Macao antes de la imposición de las medidas era prácticamente nulo ${ }^{26}$. La autoridad europea corroboró que China suministraba a Macao piezas del calzado afecto a medidas en un estado casi terminado, de modo tal que las operaciones de montaje correspondían a labores de pegado y acabado del producto final ${ }^{27}$, sin que existiese una razón económica que justificase tal actividad. Asimismo, se verificó que las importaciones de calzado procedente de Macao ingresaban al territorio de la Unión Europea a precios muy inferiores al nivel de eliminación del perjuicio a la rama de producción europea establecido en la investigación original. Así, la investigación concluyó que el margen de dumping de las importaciones de

\footnotetext{
${ }^{24}$ Con excepción de calzado deportivo, calzado fabricado con tecnología especial, pantuflas y demás calzado de casa y con puntera de protección.

${ }^{25}$ El proceso de acabado consiste en cortar los rollos de tela, colocar una cinta perimetral y etiquetas de identificación para obtener el cobertor terminado.

${ }^{26}$ Durante la investigación se observó un aumento de importaciones del producto investigado en 10 millones de pares entre 2006 - 2007 (periodo de análisis), con relación al 2005. De manera similar, se observó que las importaciones de calzado de Macao superaban los 100 millones de euros.

${ }^{27}$ En la investigación se determinó que el valor añadido de las piezas utilizadas en el montaje no superó el $25 \%$ del valor del costo de producción y que el costo de producción de las operaciones de montaje en Macao representaba entre el $6 \%$ y el $18 \%$. Asimismo, se determinó que las representaban más del $60 \%$ del valor total de las materias primas del producto investigado.
} 
calzado procedente de Macao osciló entre 8\% a 57\%. Por estos motivos, se dispuso que el calzado con parte superior de cuero de Macao quede sujeto al pago del mismo derecho impuesto en la investigación original sobre el calzado procedente de China.

Considerando los referentes de la legislación internacional antes mencionados, y con la finalidad de mejorar la regulación que actualmente existe respecto de esta modalidad, en el proyecto se propone considerar como una práctica de elusión, la importación de un producto que haya sido producido, ensamblado o acabado en un tercer país o territorio aduanero con insumos, piezas, partes o componentes procedentes del país de origen del producto sujeto a derechos, con el objeto de obtener un producto con las mismas características físicas y usos que el producto sujeto a derechos. Para ello, de manera similar a lo establecido en la legislación comparada, se precisa los criterios que la Comisión deberá considerar para efectuar su análisis en cada caso ${ }^{28}$.

(iii) La importación de un producto sujeto a derechos con modificaciones o alteraciones menores que no impliquen un cambio en sus características esenciales

Esta modalidad de elusión no está prevista actualmente en el Reglamento, sin embargo, se encuentra regulada en las legislaciones de Estados Unidos (literal (c) de la Sección 1677j de la Ley de Aranceles de 1930), la UE (artículo 13.1 del Reglamento (CE) No 1225/2009 del Consejo), México (numeral III del artículo 89B de la Ley de Comercio Exterior) y Uruguay (literal (b) del artículo 3 del Decreto $051 / 010^{29}$ ).

Sobre la aplicación de esta modalidad, es pertinente traer a colación un caso resuelto por la autoridad europea en 2008, referido a las importaciones de mecanismos para encuadernación con anillos. En ese caso se observó que, luego del inicio del procedimiento

\footnotetext{
${ }^{28}$ Así, se establece que: (i) el producto producido, ensamblado o acabado en el tercer país o territorio aduanero tiene las mismas características físicas y usos que el producto afecto; (ii) el proceso de producción, ensamblaje o acabado es menor o insignificante; y, (iii) los insumos, piezas, partes o componentes utilizados son originarios del país o territorio aduanero sujeto a derechos y tienen un valor significativo.

${ }^{29}$ Decreto que regula las medidas antielusión del 05 de febrero de 2010.
} 
de revisión de los derechos antidumping impuestos sobre mecanismos para encuadernación con anillos originarios de China, se registró un incremento de las importaciones del mismo producto con ligeras modificaciones ${ }^{30}$.

Durante el procedimiento antielusión, la autoridad europea comprobó que las empresas importadoras habían reemplazado las importaciones de los mecanismos de encuadernación afectos al pago de medidas antidumping por un producto similar al que le habían introducido cambios insignificantes que no alteraban sus características esenciales, a fin de incluirlos en códigos aduaneros que no estaban sujetos a medidas ${ }^{31}$. Así, se determinó que no existían razones que justificaran económicamente el incremento de las importaciones del producto ligeramente modificado, pues los costos de adaptación del proceso de fabricación del producto eran mayores al ahorro en el uso de materia prima alegado por las empresas exportadoras $^{32}$. Asimismo, la autoridad europea determinó que las importaciones del producto investigado se realizaron a precios menores al precio de exportación y el valor normal establecido en la investigación original, verificando la existencia de márgenes de dumping que oscilaban entre $51,2 \%$ a $78,8 \%$. Por estos motivos, se dispuso la ampliación de la aplicación de los derechos antidumping establecidos en la investigación original sobre los mecanismos de encuadernación ligeramente modificados.

Atendiendo a los referentes de la legislación internacional antes mencionados, en el proyecto se propone considerar como una práctica de elusión, la importación de un producto que ha sido modificado o alterado con la finalidad de eludir los derechos. Para ello, de manera similar a lo establecido en la legislación comparada, se establece que las modificaciones o alteraciones no deben suponer un cambio esencial en el producto, por lo que, en la práctica, se trata de ampliar la aplicación del derecho sólo sobre aquellos

\footnotetext{
${ }^{30}$ Dichas modificaciones consistían en variaciones en la forma rectangular del producto a fin de lograr que el mismo no sea rectangular y, de esta manera, clasificarlo bajo otra partida arancelaria.

${ }^{31}$ En la investigación se determinó que las operaciones de acabado para la fabricación de cobertores no requerían montos significativos de inversión en maquinaria ni equipos especializados y no requieren la contratación de personal con conocimientos técnicos para la producción del producto.

${ }^{32}$ En efecto, si bien en la investigación se determinó que se podía obtener cierto ahorro en los costos de la materia prima utilizada en la fabricación de los mecanismos de encuadernación ligeramente modificados, éste era insignificante pues no superaba el $2 \%$ de dichos costos.
} 
productos respecto de los que se hayan realizado modificaciones leves o cambios menores, pero que conservan las características esenciales del producto afecto a derechos. A efectos de realizar esta evaluación, la propuesta normativa precisa los factores que la Comisión podrá tomar en consideración en cada caso $^{33}$.

(iv) La reorganización de canales de importación a fin de que un producto sujeto a derechos se importe a través de productores o exportadores beneficiados con un tipo de derecho individual inferior o a los cuales no se les haya aplicado derechos

Esta modalidad de elusión no está prevista actualmente en el Reglamento, sin embargo, se encuentra regulada en las legislaciones de la UE (artículo 13.1 del Reglamento (CE) $\mathrm{N}^{\mathrm{o}}$ 1225/2009 del Consejo) y México (numeral IV del artículo 89B de la Ley de Comercio Exterior).

En relación con el análisis de casos bajo esta modalidad, a modo de ejemplo, es pertinente traer a colación un caso resuelto por la autoridad europea en 2011, referido a las importaciones de determinadas bolsas y bolsitas de plástico de China. En ese caso se observó que, luego de la imposición de las medidas antidumping, se produjo un cambio en los flujos de las exportaciones del producto afecto, pues se duplicaron las exportaciones del producto afecto de una empresa exportadora (Xiamen Xingxia Polymers Co. Ltd) que había sido beneficiada con un derecho antidumping menor al impuesto a las demás empresas investigadas.

Durante el procedimiento antielusión, la autoridad europea determinó que no existían razones que justificaran económicamente el incremento de las exportaciones de Xiamen, pudiendo corroborar que ésta había sido utilizada como medio para que otras empresas exportadoras sujetas a un derecho antidumping mayor, pudieran realizar exportaciones a la

\footnotetext{
${ }^{33}$ Así, los factores que se podrán considerar son los siguientes: (i) características físicas; (ii) expectativas de los consumidores; (iii) usos finales; (iv) canales de comercialización; (v) intercambiabilidad de los productos; (vi) procesos productivos; (vii) diferencias en los costos de producción; y, (viii) costos de transformación del producto con modificaciones o alteraciones.
} 
Unión Europea ${ }^{34}$. Asimismo, la autoridad europea determinó que las exportaciones procedentes de Xiamen se realizaron a precios menores al precio promedio fijado durante la investigación, verificándose la existencia de un margen de dumping superior al fijado como derecho residual $(28,8 \%)$. Por estos motivos, dispuso que el derecho residual fijado en la investigación original se ampliase sobre las exportaciones que se declaren como fabricadas por Xiamen ${ }^{35}$.

Atendiendo a los referentes de la legislación internacional antes mencionados, en el proyecto se propone considerar como una práctica de elusión, la importación de un producto sujeto a derechos a través de productores o exportadores beneficiados con un tipo de derecho individual inferior o a los cuales no se les haya aplicado derechos, con el consecuente menoscabo de las medidas impuestas. Para ello, de manera similar a lo establecido en la legislación comparada, la propuesta hace referencia a la reorganización de los canales de importación, lo cual permitirá contrarrestar las prácticas de elusión a nivel de los importadores y de los exportadores de los productos sujetos a derechos.

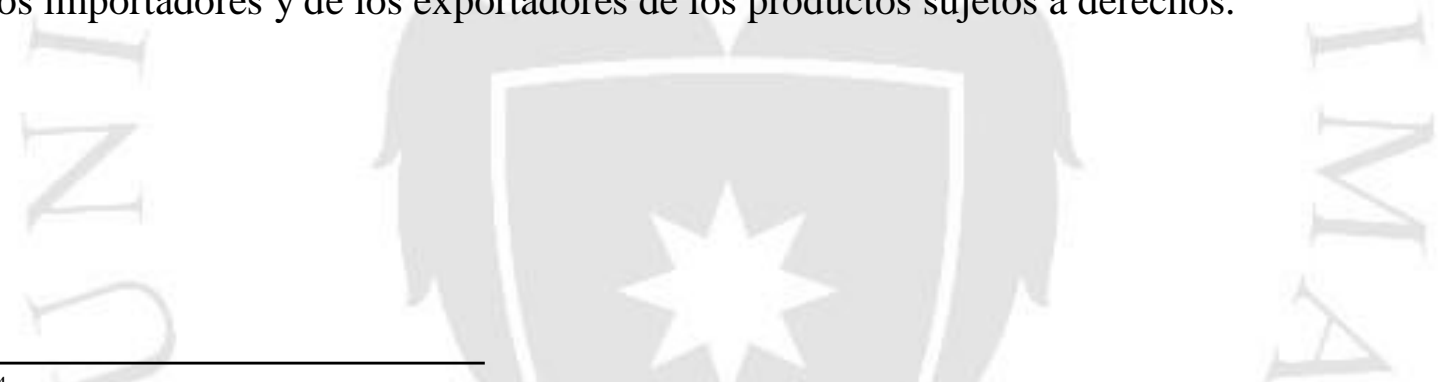

\footnotetext{
${ }^{34}$ En la investigación se determinó que si bien la empresa investigada había declarado que subcontrató fases de producción -lo que le permitía incrementar sus exportaciones- en la práctica se verificó que se trataba de la producción del producto afecto por parte de otras empresas productoras chinas.

35 Asimismo, también es pertinente traer a colación un caso resuelto por la autoridad mexicana en 2001, referido a las importaciones de carne de bovino en cortes, deshuesada y sin deshuesar de Estados Unidos. En ese caso se observó que, a partir de la publicación de la resolución definitiva que impuso los derechos antidumping, se incrementaron las importaciones del producto afecto (carne de bovino en cortes, deshuesada y sin deshuesar) a través de una empresa a la que no se le había impuesto un derecho antidumping en la investigación original (Northern Beef Industries Inc.). Durante el procedimiento antielusión, la autoridad mexicana verificó un incremento de las exportaciones de Northern Beef al mercado mexicano, así como un incremento de su participación en dicho mercado. Asimismo, se pudo corroborar que las exportaciones de Northern Beef estaban compuestas, en su mayoría $(67,7 \%)$, por la producción de empresas exportadoras a las que se les había aplicado derechos antidumping individuales en la investigación original. Por estos motivos, la autoridad mexicana modificó la resolución que impuso los derechos antidumping definitivos, precisando que no están sujetas a derechos antidumping las exportaciones de carne realizadas por Northern Beef, siempre y cuando dicho producto haya sido producido por las empresas Excel Corporation, Farmland National Beef Packing, ConAgra Inc. y ConAgra Beef Company, las cuales se identificó en la investigación original que no realizaban prácticas de dumping.
} 
(v) La importación de un producto sujeto a derechos sin que se haya demostrado conforme a la normativa de la materia, que tiene un origen distinto al del país o territorio aduanero de las importaciones afectas a derechos

Esta modalidad de elusión no está prevista actualmente en el Reglamento, sin embargo, se encuentra regulada en las legislaciones de la UE (artículo 13.1 del Reglamento (CE) $\mathrm{N}^{\mathrm{o}}$ 1225/2009 del Consejo) y Uruguay (literal (a) del artículo 3 del Decreto 051/010).

En relación con el análisis de casos bajo esta modalidad, a modo de ejemplo, es pertinente traer a colación un caso resuelto por la autoridad europea en 2011, referido a las importaciones de biodiésel desde Canadá, esté o no declarado como originario de dicho país. En ese caso se observó que las importaciones del producto afecto con medidas compensatorias - biodiésel en mezclas con un contenido igual o inferior al $20 \%$ en peso de biodiésel originario de Estados Unidos- fueron reemplazadas por importaciones del mismo producto procedente de Canadá ${ }^{36}$.

Durante el procedimiento antielusión, la autoridad europea determinó que no era posible que los productores canadienses pudieran haber producido el volumen de biodiésel exportado al mercado europeo pues la industria para producción de biodiésel en ese país era incipiente. Así, se comprobó que Canadá era sólo una escala previa de las exportaciones americanas que tenían como destino final la Unión Europea. En tal sentido, no existían razones que justificaran económicamente el tránsito de las exportaciones de biodiésel desde Canadá, más que la finalidad de eludir el pago del derecho compensatorio. Por estos motivos, la autoridad americana dispuso que los derechos compensatorios impuestos en la investigación original sobre las importaciones de biodiésel de Estados Unidos fueran ampliados sobre las importaciones de biodiésel de Canadá.

Atendiendo a los referentes de la legislación internacional antes mencionados, y con la finalidad de complementar las disposiciones establecidas en el Decreto Supremo № 0052011-MINCETUR emitido por el Ministerio de Comercio Exterior y Turismo, a través del

\footnotetext{
${ }^{36}$ En la investigación se determinó que el producto afecto era exportado desde Estados Unidos hacia Canadá y, posteriormente, enviado a la Unión Europea.
} 
cual se establece el marco normativo para la declaración y control del origen de las mercancías sujetas a medidas de defensa comercial, en el proyecto se propone considerar como una práctica de elusión, la importación de un producto sujeto a derechos sin que se haya demostrado conforme a la normativa de la materia, que tiene un origen distinto al del país o territorio aduanero de las importaciones afectas a derechos.

(vi) La importación de un producto afecto a derechos antidumping o compensatorios que ha sido sometido a un proceso posterior de desarrollo luego de la aplicación de los derechos

Esta modalidad de elusión no está prevista actualmente en el Reglamento, sin embargo, se encuentra regulada en la legislación de los Estados Unidos (literal (d) de la Sección 1677j de la Ley de Aranceles de 1930).

En relación con el análisis de casos bajo esta modalidad, a modo de ejemplo, es pertinente traer a colación un caso resuelto por la autoridad americana en 2006, referido a las importaciones de velas compuestas por cera de petróleo y por 50\% o más de ceras de aceite de palma $y / u$ otros aceites vegetales de China. En ese caso la autoridad americana determinó que el ingreso masivo de las importaciones de dichas velas tenía por finalidad eludir el pago de los derechos antidumping impuestos anteriormente sobre las velas de cera de petróleo con mecha de fibra de papel, procedente de China. Por estos motivos, la autoridad americana estableció que las velas compuestas por cera de petróleo y por 50\% o más de cercas de aceite de palma y/u otros aceites vegetales procedentes de China se encontraban dentro del ámbito de aplicación de los derechos antidumping dispuestos en la investigación original.

Con la finalidad de determinar si las velas compuestas por cera de petróleo y por 50\% o más de ceras de aceite de palma y/u otros aceites vegetales eran el resultado de haber sometido a un desarrollo posterior el producto afecto a derechos (es decir, velas de cera de petróleo con mecha de fibra de papel) luego de aplicado los mismos, la autoridad americana determinó lo siguiente: (i) que el producto afecto había sufrido una alteración 
significativa $^{37}$; y, (ii) que no se había acreditado que el producto desarrollado posteriormente estuvo disponible comercialmente en el mismo momento que el producto afecto.

Atendiendo al referente de la legislación internacional antes mencionado, en el proyecto normativo se propone considerar como una práctica de elusión, la importación de un producto sujeto a un derecho antidumping o compensatorio que haya sido sometido a un proceso posterior de desarrollo luego de la aplicación de dicho derecho. Asimismo, la propuesta recoge lo establecido en la norma antielusión americana, en el sentido que procederá ampliar la aplicación de los derechos sobre el producto sometido a un proceso posterior de desarrollo cuando se verifiquen dos condiciones: (i) que ambos productos comparten características físicas y usos similares, aun cuando el producto sometido a un proceso posterior de desarrollo ingrese al Perú a través de una partida arancelaria distinta al producto afecto; y, (ii) que el producto sometido a un proceso posterior de desarrollo permita ejecutar las mismas funciones que el producto sujeto a derechos ${ }^{38}$.

(vii) Cualquier otra conducta que tenga por finalidad eludir el cumplimiento del pago de un derecho antidumping o compensatorio

La mayoría de las legislaciones revisadas (el numeral $\mathrm{V}$ del artículo 89B de la Ley de Comercio Exterior de México, el artículo 13.1 del Reglamento (CE) N ${ }^{\circ}$ 1225/2009 del Consejo de la UE, el literal (c) del artículo 59 del Decreto 1393/2008 de Argentina y el literal (c) del artículo 3 del Decreto 051/010 de Uruguay) contemplan una cláusula general

\footnotetext{
${ }^{37}$ En la investigación se determinó que la cera dentro de la composición de una vela es importante. En tal sentido, un cambio en más del $50 \%$ es significativo. En la medida que en el caso se habían adicionado ceras vegetales y/o de palma a las velas que eran $100 \%$ producidas en base a petróleo, se podía concluir que el cambio era significativo.

${ }^{38}$ En relación con este último supuesto, cabe precisar que la propuesta normativa, recogiendo lo establecido en la legislación americana, precisa que cuando el producto investigado permita ejecutar funciones adicionales, éstas no deben constituir el uso primario de dicho producto y los costos de dichas funciones adicionales no puede representar más que una proporción significativa del costo total de producción.
} 
que permite analizar otras prácticas de elusión no listadas expresamente en sus normas, siempre que se verifique el cumplimiento de ciertos requisitos.

En la medida que las prácticas de elusión pueden manifestarse en conductas que no siempre son posibles de anticipar, y con la finalidad enfrentar en el futuro cualquier nueva modalidad de elusión que menoscabe los efectos correctores de los derechos que imponga la Comisión, se ha considerado pertinente incluir en la propuesta normativa, una cláusula general comprensiva de cualquier otra modalidad de elusión no contemplada expresamente en el Reglamento. A tal efecto, la aplicación de dicha cláusula requerirá que concurran los siguientes requisitos:

a) un cambio en las características del comercio;

b) que no exista justificación económica para dicho cambio, distinta del establecimiento del derecho; $y$,

c) que la práctica elusoria tenga una repercusión negativa sobre los efectos correctores de los derechos.

En cuanto al requisito (i), debe indicarse que las prácticas de elusión se manifiestan a través de un cambio en las características del comercio entre terceros países y el país importador que impuso los derechos, entendiéndose también que este cambio puede producirse entre empresas individuales del país sujeto a derechos vigentes y el país importador. Dicho cambio, por lo general, consiste en que luego de la imposición de las medidas, se registra un incremento de las importaciones de un producto de un tercer país que no se encuentra sujeto a medidas vigentes; o, un incremento de las importaciones de partes o piezas del producto afecto, aunque también puede significar una alteración de un producto sin una justificación económica ${ }^{39}$.

\footnotetext{
$39 \mathrm{Al}$ respecto, Van Bael \& Bellis en "Anti-dumping and other Trade Protection Laws of the EC" señala lo siguiente:

"Normally, a change in the pattern of trade will mean an increase in imports from a third country not subject to anti-dumping measures or increased imports of parts of the product subject to the measures. However, it could also mean altering a product without economic justification "
} 
En relación con el requisito (ii), es necesario verificar si el cambio de comercio se encuentra justificado económicamente, lo que abre la posibilidad para que las empresas exportadoras extranjeras o los importadores nacionales sustenten y prueben que dicho cambio en los flujos comerciales obedece a razones económicas o de mercado distintas a la elusión de los derechos.

Finalmente, respecto al requisito (iii), cabe indicar que resulta necesario que existan evidencias de que las importaciones efectuadas bajo modalidades de elusión no contempladas expresamente en la norma, tienen una repercusión negativa sobre los efectos correctores de los derechos, pues ésta es la principal justificación para la imposición de medidas antielusión. Este menoscabo podrá ser verificado al comprobar que se produce el ingreso de importantes volúmenes de importaciones que eluden el pago de los derechos, a precios subvalorados en relación a los precios de la rama de producción nacional, para lo cual podrá verificarse si existe dumping en relación con el valor normal establecido en la investigación original en que se impusieron los derechos que se pretende eludir.

En relación con el análisis de casos bajo la cláusula general, a modo de ejemplo, es pertinente traer a colación un caso resuelto por la autoridad colombiana en 2005 , referido a las importaciones de vajillas y piezas sueltas de porcelana procedentes de China. En ese caso se observó que, luego de la imposición de las medidas antidumping sobre vajillas y piezas sueltas de loza, se produjo un cambio en los flujos de las exportaciones del producto afecto, pues se incrementaron las importaciones de vajillas y piezas sueltas de porcelana que no se encontraban afectas al pago de las medidas ${ }^{40}$.

Durante el procedimiento antielusión, la autoridad colombiana comprobó un drástico descenso de las importaciones de vajilla y piezas de loza sólo en el primer semestre posterior a la imposición de las medidas, mientras que las importaciones de vajilla y piezas de porcelana mostraron un incremento importante ${ }^{41}$, apreciándose, además, un aumento de

\footnotetext{
${ }^{40} \mathrm{Si}$ bien la investigación se inició sobre las importaciones de vajillas y piezas de porcelana, así como vajillas y piezas de loza, la autoridad colombiana sólo dispuso la aplicación de medidas sobre estas últimas, al no haberse determinado la existencia de daño en la rama de producción colombiana causado por las importaciones de vajillas y piezas de porcelana.

${ }^{41}$ Así, mientras que las importaciones de vajillas de loza cayeron 70,64\%, las de porcelana crecieron 36,58\%.
} 
la participación de las importaciones chinas de porcelana en el mercado colombiano, en detrimento de los productores colombianos, quienes fueron desplazados ${ }^{42}$. Asimismo, la autoridad colombiana determinó que las prácticas de elusión habían generado daño en los principales indicadores económicos de la rama de producción colombiana. Por estos motivos, se dispuso imponer un derecho antidumping a las importaciones de vajillas y piezas de porcelana, similar al establecido para las importaciones de vajillas y piezas de loza

\section{$\underline{\text { Artículo 58B }}$}

En cuanto a las disposiciones procesales contenidas en el artículo 58B, la propuesta busca crear un procedimiento especial para la tramitación de los procedimientos antielusión.

Se propone que el procedimiento tenga una duración menor al que corresponde a las investigaciones, acorde con la naturaleza y finalidad del mecanismo antielusorio. Así, la norma propuesta establece que el procedimiento será concluido por la Comisión en un plazo máximo de siete (7) meses (el cual incluye un periodo probatorio de tres (3) meses); estableciéndose además un plazo de cuatro (4) meses para resolver los recursos de apelación que se interpongan contra las decisiones emitidas por la primera instancia. Asimismo, se establece que el procedimiento, además de ser iniciado de oficio, podrá ser iniciado a pedido de parte con legítimo interés.

Adicionalmente, de manera similar a lo establecido en la legislación de la UE (artículo 13.3 del Reglamento (CE) N $1225 / 2009$ del Consejo), la propuesta normativa establece que en el acto de inicio deberá disponerse que la autoridad aduanera exija a los importadores del producto investigado, como condición para el retiro de sus mercancías, el otorgamiento de cartas fianzas bancarias como garantía de pago de los derechos antidumping o compensatorios que finalmente se determinen en el procedimiento antielusión. Con dicha disposición se asegura el cumplimiento de las decisiones emitidas en los procedimientos

\footnotetext{
${ }^{42}$ En efecto, mientras que China obtuvo $87,2 \%$ de participación en el mercado de porcelana colombiano, los productores de dicho país alcanzaron a representar el $8,4 \%$ de dicho mercado.
} 
antielusión, garantizando la efectividad de las mismas y la protección de las ramas de producción nacional afectadas por las prácticas desleales de comercio.

\section{Artículo 33 del Reglamento}

El Reglamento actual detalla las resoluciones que deben ser publicadas en el diario oficial El Peruano, incluyendo entre ellas las que disponen el inicio de la investigación, así como las que establecen derechos antidumping o compensatorios.

En la medida que se está proponiendo incorporar al Reglamento un procedimiento para enfrentar las prácticas de elusión de derechos antidumping y compensatorios, es necesario que en el Artículo 33 del Reglamento se incluya, entre aquellas resoluciones que deben ser publicadas, las que tienen por objeto ampliar la aplicación de derechos antidumping o compensatorios, emitidas en el marco de los procedimientos antielusión que tramite la Comisión.

\section{Artículo 57 del Reglamento}

Conforme a lo dispuesto en el artículo 57 del Reglamento, Aduanas deberá remitir a la Comisión, dentro del mes siguiente al cierre de cada trimestre, informes sobre la aplicación de los derechos antidumping y compensatorios, con información sobre los volúmenes y el valor de las importaciones de los productos sujetos a derechos, la cantidad recaudada por

los mismos y la relación de las cartas fianzas otorgadas sobre los derechos provisionales vigentes.

En la medida que se está proponiendo incorporar al Reglamento un procedimiento para enfrentar las prácticas de elusión de derechos antidumping y compensatorios, es necesario que en el Artículo 57 del Reglamento se incluya, entre la información que Aduanas debe remitir a la Comisión en sus informes trimestrales, la relación de las importaciones que hayan quedado sujetas a los procedimientos de verificación de origen a que se hace referencia el artículo $7^{\circ}$ del Decreto Supremo $N^{\circ}$ 005-2011-MINCETUR, así como la relación de dichos procedimientos concluidos y sus resultados. En ambos casos, se dispone 
que dentro de la información que Aduanas debe remitir, se indique el nombre de las personas naturales y/o jurídicas que realizaron las importaciones, el volumen, el valor y el origen declarado por los importadores y el número de declaración aduanera correspondiente.

\section{AnÁlisis COSTO - BenEFICIO}

A continuación se desarrolla el análisis costo beneficio del presente proyecto normativo a fin de sustentar que las modificaciones propuestas al marco normativo vigente se encuentran justificadas y son necesarias y apropiadas. Para ello, se expondrá los posibles beneficios, costos y efectos de la norma propuesta.

La incorporación de normas antielusión en el Reglamento permitirá fortalecer la aplicación de la legislación en materia de defensa comercial. Así, la autoridad administrativa, además de aplicar derechos antidumping y compensatorios para corregir las distorsiones generadas en el mercado por las prácticas de dumping y las subvenciones, podrá establecer medidas contra aquellas prácticas comerciales que tengan por finalidad eludir tales derechos, garantizando la eficacia de los mismos y coadyuvando al buen funcionamiento del mercado interno.

Del mismo modo, las disposiciones en materia antielusión permitirán atender los requerimientos de la industria local frente a las prácticas desleales que se verifiquen en las importaciones, más aún considerando el actual contexto de apertura comercial del Perú a otros mercados, en virtud de los acuerdos de libre comercio celebrados durante los últimos años.

En efecto, durante último quinquenio, se ha impulsado en el país una política de apertura comercial a través de la suscripción de acuerdos comerciales, lo que contribuye al crecimiento sostenido de la economía nacional y al bienestar general. Si bien la suscripción de los acuerdos de comercio celebrados por el Perú generarán mayores oportunidades de intercambio comercial con el consiguiente beneficio que ello genera para el país, no debe descartarse que este incremento de los flujos comerciales puede propiciar la aparición de 
prácticas desleales en las importaciones que afecten el buen funcionamiento del mercado nacional.

En tal sentido, las disposiciones en materia antielusión recogidas en la propuesta normativa no sólo permitirán asegurar el cumplimiento y la efectividad de las decisiones que emita la Comisión en los procedimientos de investigación por prácticas desleales de comercio, sino que también garantizarán condiciones equilibradas de intercambio comercial para que el Perú, de forma similar que sus socios comerciales, cuente con una herramienta legal idónea para enfrentar las prácticas elusoras.

Con relación a los beneficios concretos de la propuesta normativa, se pueden mencionar los siguientes:

- Promover los objetivos de las políticas en materia de defensa comercial, como son el combate de las prácticas desleales que afectan el funcionamiento del mercado interno y la consolidación de una cultura de mercado en el Perú.

- Contrarrestar de manera efectiva el daño que las prácticas desleales de comercio causan a la producción nacional, de forma que se salvaguarde el óptimo desenvolvimiento de las ramas de producción nacional que generan fuentes de trabajo productivo en el país.

- Contar con un procedimiento especial acorde con la naturaleza de las prácticas elusoras investigadas, reduciendo significativamente los costos en los que incurren los usuarios del sistema y el Estado para reprimir tales prácticas.

- Asegurar el cumplimiento de las decisiones emitidas por la Comisión que imponen derechos antidumping y compensatorios, garantizando la efectividad de las mismas y las condiciones de competencia leal dentro del mercado nacional.

- Reforzar las competencias de la autoridad investigadora nacional y facilitar el ejercicio de las funciones que le han sido encomendadas por ley.

- Fortalecer la capacidad de investigación de la autoridad investigadora nacional, lo que redundará en la solución oportuna y apropiada de los procedimientos de investigación, en beneficio directo de los usuarios y del sistema de defensa comercial en el Perú. 
- Coadyuvar a la predictibilidad de las decisiones de la autoridad y facilitar la observancia de las mismas por parte de los agentes económicos, al establecer con claridad aquellas prácticas que califican como elusoras de derechos antidumping y compensatorios, así como las etapas y plazos específicos para el desarrollo de las investigaciones.

De otro lado, los costos involucrados son los siguientes:

- Los costos de verificación y control de las operaciones de importación a fin de determinar que las mismas no están eludiendo el pago de los derechos antidumping y compensatorios.

- Los costos administrativos que supone la tramitación de los procedimientos antielusión por parte de la autoridad investigadora.

- Los costos de implementación de infraestructura adecuada, así como aquellos que irroguen a la autoridad la tramitación de los procedimientos antielusión.

- Los recursos que se deberán invertir en la difusión de las modificaciones introducidas al Reglamento en materia antielusión entre los usuarios del sistema (productores nacionales, gremios, importadores, agentes de aduanas, estudios de abogados).

Con relación a los costos asociados a la implementación de la propuesta normativa debe tenerse en cuenta que, en la actualidad, se cuenta con un mecanismo de control y verificación de las operaciones de importación, el cual permitirá identificar aquellas importaciones que pretenden eludir el pago de los derechos antidumping y compensatorios. Asimismo, debe tenerse en consideración que el actual sistema de defensa comercial cuenta con infraestructura adecuada y con una autoridad investigadora con experiencia encargada de tramitar las investigaciones por prácticas desleales de comercio, por lo que no es necesario crear una nueva infraestructura y una autoridad especial para la tramitación de los procedimientos en materia de elusión de derechos antidumping y compensatorios, debiendo recaer dicha función en la Comisión de Fiscalización de Dumping y Subsidios 
que es la autoridad que por mandato legal tiene a su cargo las investigaciones antidumping y sobre subvenciones. Finalmente, no se comprometerán fondos del Tesoro Público en la implementación de las modificaciones propuestas en el proyecto normativo, en la medida que los costos de tramitación de los procedimientos antielusión serán financiados íntegramente con las tasas administrativas que directamente recaude el INDECOPI, las cuales se establecerán previamente en el Texto Único de Procedimientos Administrativos de la Institución.

En tal sentido, si bien existen costos asociados a la implementación de la propuesta normativa, el análisis antes referido demuestra que éstos son significativamente menores a los importantes beneficios que reportará su implementación. Así, la propuesta normativa permitirá ofrecer una mejor protección a las ramas de producción nacional frente a las prácticas de elusión del pago de las medidas antidumping y compensatorias que se impongan en los procedimientos de investigación, coadyuvando a generar condiciones de competencia leal entre los agentes económicos que intervienen en el mercado.

Atendiendo a lo expuesto, el análisis de costo y beneficio demuestra que los beneficios que generará la puesta en vigencia de la norma son notoriamente superiores a los costos de su cumplimiento. 


\title{
ANEXO N 3
}

\author{
Material de Audio
}

\section{ENTREVISTA A JAIME DUPUy ORTIZ DE ZEVALlos, GERENTE DE ESTUDIOS ECONÓMICOS Y CONSUltoría EMPRESARIAL DE LA SOCIEDAD DE COMERCIO EXTERIOR DEL PERÚ}

(COMEX), REALIZADA EL 3 DE NOVIEMBRE DE 2016

Giuliana Paredes: ¿Desde su experiencia qué opinión le merece esta problemática?, ¿Desde su punto de vista, cómo debería abordar el INDECOPI, a través de la Comisión de Dumping, Subsidios y Eliminación de Barreras no arancelarias, el tema?

JAIME DUPUY: Primero me gustaría comentarte la apreciación que tenemos respecto al dumping y cómo se ha venido utilizando. Para comenzar es una medida de defensa comercial que está sujeta a normas internacionales y estamos convencidos debe aplicarse correctamente cuando se dé. Lo que hemos visto también es que muchas investigaciones que se han iniciado no se han sujetado a las disposiciones que establecen la OMC y a las normas que están replicadas en la legislación interna. Si te pones a pensar el origen del antidumping tiene que ver también con la protección a la industria nacional, muchas veces se puede tergiversar el uso del mecanismo, como una medida proteccionista y no cuando se han dado las condiciones, sino con un ánimo de proteccionismo a la industria nacional.

Ahora con respecto a la elusión, definitivamente siempre que haya una disposición en cualquier parte, las empresas van a intentar adaptarse a las circunstancias y eludir, es decir, no cumplir con algo, pero con los márgenes que te pone la legislación. Pero en principio creo que va a ser difícil que puedas regular todas aquellas disposiciones que puedan darse para que los empresarios busquen otras alternativas y no estén sujetos a estos procedimientos. Si al final encontramos que sí efectivamente sale a la luz que hay algo que deba regularse, perfecto, siempre y cuando se haga de acuerdo a los parámetros 
internacionales y de la experiencia internacional. Y que cada regulación adicional que se haga, primero, no pueda convertirse en una disposición que restrinja u obstaculice el desarrollo económico y el flujo comercial y ni que a su vez sea usado para promover medidas proteccionistas.

Giuliana Paredes: Se ha emitido una propuesta normativa que incluye diversos supuestos de elusión y una cláusula general, el cual se basa, de algún modo, en los casos que la autoridad peruana ha ido enfrentado ¿Cuál es su posición respecto a la modificación normativa y a la inclusión de medidas antielusivas?, y ¿qué recomendaciones, sugerencias o consideración, según su juicio, la Comisión tener en cuenta para la modificación del Reglamento Antidumping?

JAIME DUPUY: Eso pasó para el caso de las confecciones en China, cuando empiezan a disponer el margen de dumping, se establecen determinadas empresas exportadoras chinas y habían dos que no pagaban dumping y tú veías cómo al final, no es que tanto bajo el volumen de importación, sino que se canalizó a estos dos que no pagaban derechos, entonces, al final no estas teniendo los efectos que quieres porque, independientemente no consideramos que debería haber derechos antidumping en específicamente ese caso, la forma en la que se había dispuesto, en verdad lo que se hacía era sacarle la vuelta y darle un negocio a estos dos exportadores chinos.

Si es que definitivamente hay vacíos que se están encontrando y hay experiencia cada vez más grande donde se acredite que efectivamente hay que regular algo adicional, en buena hora.

Este tema hay que discutirse para que el mecanismo sea eficiente, entonces, acá no se trata de inventar cosas nuevas, sino que son prácticas internacionales que se dan y si al final hay algo que mejorar ahí, entonces, hay que hacerlo, siempre que, eso sí te lo resalto, que no signifique trabas que se pueda generar dentro de los flujos de comercio

Me gustaría ver bien cómo se va a regular eso para que tampoco no se preste a errores y que al final productos que de repente no tendrían por qué ser afectados, se afecten. Por ello, tendríamos que ver bien cómo se regula, pero me suena lógica la idea, si al final se está tratando de sacarle la vuelta y hacer algo en el producto, por ejemplo, para cambiarla de 
partida y que ingrese con precio dumping. Parecería razonable que exista un procedimiento más expedito para poder aplicar derechos adicionales, pero habría que verse bien cómo se regula, justamente para que haya la predictibilidad que mencionas.

GiUliana Paredes: Dentro de la propuesta se ha dispuesto solo un procedimiento para todos los supuestos de elusión, sin embargo, de acuerdo a mi investigación he visto que podría ser preferible, ya que cada fórmula elusiva tiene características y criterios disímiles, por ejemplo podría afectarse a terceros tales como a exportadores, productores o importadores de los insumos partes, piezas o componentes, por ello he propuesto que en algunos supuestos deben realizarse una investigación por dumping y daño porque la investigación se extendería a otro país y agentes comerciales. Po lo que, recomiendo establecer varios procedimientos de acuerdo a los criterios comunes.

JAIME DUPUY: Sí suena razonable y justo lo que estaba pensando cuando estabas comentando es respecto a riesgos que se puedan presentar porque tú tienes que ahora en los acuerdos comerciales, algo que está teniendo bastante fuerza, es el tema de acumulación de origen, o sea, tanto en el TPP, Alianza del Pacífico, TLC con Estados Unidos había una disposición para que proceda acumulación de origen, la idea es que se crean cadenas globales de valores, algo que también se está discutiendo bastante en el marco del APEC, en donde tengas un producto que pueda estar compuesto por insumos de muchas partes y que no pierda originalidad, entonces, por ejemplo en la Alianza del Pacífico puedes tener la industria automotriz mexicana donde Perú pueda insertarse con algunos tipos de componentes como frenos y que eso no haga perder al producto final la calidad de origen mexicano para efectos de la importación en el marco de la Alianza del Pacífico sujetos a beneficios arancelarios, la idea es que con esta teoría de ventajas comparativas de los países que cada uno sea bueno en lo que es competitivo, entonces, de repente tu no vas a ser bueno en productos finales, sino en determinados segmentos de la cadena, entonces, yo creo que va a haber un crecimiento justamente de insumos y componentes, entonces, que esto no pueda utilizarse como una restricción para esto o que pueda perjudicar el desarrollo de este incremento de exportaciones en el comercio exterior que pueda realizarse

Giuliana Paredes: Lo que se está viendo es desarrollar varios criterios para que se pueda determinar finalmente de que cierta conducta responde a una práctica de elusión y no a una 
práctica económica válida dentro del comercio ¿Desde el cargo desde el que usted se desempeña, cuál sería la posición de los importadores?

JAIME DUPUY: Bueno por parte de los importadores se quiere justamente que los dejen trabajar y no haya mayor carga, mientras existan disposiciones predecibles que justamente no estén vulnerando las operaciones normales de comercio, no creo que haya ningún problema. El que va a estar preocupado va a ser quien vea que estas disposiciones sean mal utilizadas y que pueda afectar su flujo de comercio y sus negocios y, segundo, los que tengan miedo de que haya mayor rigurosidad porque sí cometen esos tipos de prácticas.

Por parte de los productores nacionales, creo que cualquier medida adicional creo que va a ser bienvenida para ellos porque van a tener más herramientas para después utilizar frente a amenazas externas.

Giuliana Paredes: ¿Qué incidencia comercial y económica cree pueda generar la inclusión de una normativa antielusión? Por ejemplo, se ha dicho que la inclusión de una normativa antielusiva va a desencadenar graves consecuencias afectando la Balanza de Pagos el PBI y el comercio exterior peruano. Además, podría desincentivar las importaciones de productos de países extranjeros hacia el Perú.

JAIME DUPUY: No creo que haya una consecuencia directa. De hecho afectación al comercio siempre va a haber no sé en qué magnitud pueda ser, pero si tú te pones a pensar, como requisito previo tiene que haberse determinado un dumping, tienen que haber derechos antidumping ya impuestos a un producto para que haya después una disposición adicional, o sea, debería haber una investigación que ya previamente se ha hecho, entonces, no son normas (las antielusivas) que genere un efecto tan inmediato o rápido de afectar decisiones comerciales porque al final vas a tener un filtro previo donde hay un proceso de investigación donde se estime que efectivamente hay un dumping. De hecho siempre va a haber algún impacto, pero no creo que sea considerable sobre todo dependiendo de cómo sea la regulación.

Giuliana Paredes: ¿Esta problemática ha sido materia de la agenda en el quehacer de COMEX Perú? 
JAIME DUPUY: El tema de dumping sí lo hemos tocado bastante, justamente a raíz de un caso concreto que hemos estado muy interesados, pero en realidad, respecto a la elusión sería interesante investigarlo y cuando haya una propuesta concreta y otra vez el tema se materia de discusión definitivamente sí nos gustaría participar y meternos de lleno. Yo personalmente sería de la idea que éste tipo de disposiciones nazcan de un acurdo de la OMC y que después se pueda replicar acá. Pero, en general, es un tema que nos atañe directamente cuando exista la propuesta completa.

Comentarios.- $\mathrm{Si}$ bien Jaime Dupuy precisa que los importadores preferirían comercializar sus productos libre de barreras paraarancelarias, es importante abordar el tema de la elusión y cubrir normativamente el vacío legal existente, ya que existen casos que exponen una problemática que afecta al sistema antidumping. El gerente de Estudio Económicos recomienda que las disposiciones antielusivas sean claras y se ajusten a los parámetros establecidos por los acuerdos internacionales suscritos como país miembro de la Organización Mundial de Comercio. Finalmente, Dupuy manifiesta que sería más preferible que se uniformicen los criterios antielusivos mediante un consenso multilateral, sin embargo, reconoce que, debido a la alta cantidad de países miembros, es complicado llegar a un acuerdo. 


\title{
$\operatorname{ANEXO~N}^{\circ} 4$
}

\author{
MATERial de AUdio
}

\author{
ENTREVISTA A Silvia HoOKER, GERENTE DE COMERCIO EXTERIOR DE LA SOCIEDAD \\ NACIONAL DE INDUSTRIAS (SNI), REALIZADA EL 11 DE NOVIEMBRE DE 2016
}

GiUliana Paredes: Como se ha incrementado la aplicación de los derechos antidumping, tanto a nivel nacional como a nivel internacional. Muchos productores y exportadores de países extranjeros, especialmente las naciones asiáticas, han estado ejecutando fórmulas de elusión para poder evitar el pago de estos derechos. ¿Desde su experiencia qué opinión le merece esta problemática?

Silvia HoOKer: En primer lugar el tema de los derechos antidumping efectivamente es un tema que se está utilizando mucho a nivel mundial; en Perú considero que se está utilizando muy poco, creo que estamos debajo del estándar en la aplicación de medidas antidumping, a pesar de que somos un país muy abierto, nosotros importamos de forma continua bienes de todas partes del planeta y tenemos una economía que permite que venga cualquier producto, a cualquier precio y no estamos siendo atentos de los problemas que trae la importación a precio desleal. Dicho esto, considero que el problema de la elusión es muy serio porque tenemos que el productor nacional ha tenido que invertir horas, dinero y tiempo en probar el alto estándar probatorio que se tiene que demostrar para poder obtener un derecho antidumping por parte del Estado, además, de todo el gasto en el que el Estado ha tenido que incurrir en hacer una investigación y cumplir con los estándares establecidos por la OMC, no estamos lo suficientemente atentos. Tú me hablas de los exportadores, pero yo también lo miro desde otro punto de vista y mi experiencia me dice que gran parte de la elusión lo hacen los importadores nacionales. ¿Qué tipo de problemas trae esto? De hecho toda una inversión por parte del Estado, por parte de la Rama de Producción Nacional para 
poder equilibrar el mercado hacia un precio que sea el precio normal de competencia, esto se ve vulnerado por estas prácticas elusivas. Creemos que es tiempo para que se dé una norma antielusión, actualmente el INDECOPI cuenta herramientas muy mínimas y básicas en el Decreto Supremo 006-2003-PCM para el tema de elusión, mas sé que INDECOPI identificó en su momento un proyecto de norma antielusión y hasta el día de hoy esa norma no sale a la luz por una errónea visión que tiene el Ministerio de Economía y Finanzas respecto de que es mejor vivir en el mundo de "dejar que todo pase y que el Estado no intervenga", pero si ya el Estado invirtió dinero, se cumplió los estándares de la OMC, la rama de producción nacional obtuvo válidamente una medida de para que el mercado vuelva a su nivel regular, es absurdo no velar porque eso se cumpla. Entonces tú ves medidas de elusión desde productos que se desarman en partes y piezas, no pagar y luego armarlos, si considero que es necesario que el Estado tome en serio su rol, el rol de administrar los acuerdos de la OMC que incluye velar porque se cumplan las medidas antidumping.

GiUliana Paredes: La posición que yo mantengo en la tesis es muy parecida a la que usted establece, existe un sistema antidumping, cuyas reglas y criterios han sido uniformizadas por la OMC y en la medida en que la Comisión siga estos requisitos, una aplicación de derechos antidumping es legítima. De alguna manera de desincentiva a los exportadores y productores nacional, pues si estos inician un procedimiento antidumping que puede durar hasta un año y éstos se dan cuenta que se está eludiendo esta medida y vuelven a recurrir al INDECOPI, pero hay un vacío legal, por lo que, la Comisión está atada de manos y no puede pronunciarse al respecto, entonces, ¿cuál es el mensaje que se está enviando a estos exportadores peruanos?

Silvia Hooker: Cuando Perú entró al proceso de apertura de los TLC, se le dijo a los productores nacionales que los derechos antidumping y su aplicación se iban a respetar y no se iban a restringir. Entonces ellos decían, si los aranceles son los que me protegen y ahora me vas a quitar los aranceles por los acuerdos, ahora la autoridad señala que eso no es así porque si se quiere proteger en contra de las prácticas desleales, se aplican derechos antidumping o compensatorios, no aranceles. Y hay una sensación de que fueron engañados o estafados, ellos dicen, ya yo accedí a que se eliminaran los aranceles por los 
acuerdo comerciales y accedí a competir, pero quiero competir en una leal competencia, no quiero competir con alguien que me está haciendo daño con la práctica desleal.

GiUliana Paredes: La norma que regula todos estos temas es el Decreto Supremo 0062003-PCM y éste aborda el tema de elusión sólo en un artículo referente a partes, piezas y componentes, pero éste es muy limitado. Las personas que se oponen a normar en contra de la elusión señalan que no existen casos que se han configurado a nivel de INDECOPI. Por ejemplo, hubo un caso en el que la Comisión decidió extender los derechos antidumping, sin embargo, a nivel judicial, en base al principio de legalidad, se tuvo que revocar la medida.

Silvia Hooker: Casuística no vas a encontrar porque justamente no hay cómo encausarlo, hay denuncias no llegan a configurarse como casos porque nos topamos con que no hay una normativa al respecto.

GiUliana Paredes: Entonces, de acuerdo a lo que señala, entiendo que usted coincide con que el artículo 58 del Reglamento Antidumping es muy limitado y debe modificarse

SiLVIA HoOKER: Hay un proyecto de modificación donde está bien estudiado. Se estudió el derecho comparado y tomo los casos de otros países que tienen estas reglas antielusión y tratamos de sacar una norma equilibrada porque no se trata que a la loca quieras ampliar el universo y vulneres el derecho de defensa de otros importadores que traen válidamente y no eludiendo derechos. Definitiva la normativa es muy pobre y no atiende al real problema que existe

GiUliana Paredes: Este proyecto de modificación incluye varios supuestos de elusión y una cláusula general y en la tesis que desarrollo realizamos algunos comentarios a este documento, pues notamos que existe, por ejemplo, alguna terminología ambigua. Se podría cuestionar qué es un "valor significativo", por ejemplo, la legislación de la Unión Europea y algunos Drafts de la OMC cuantifican el término con la regla del $60 \%$ y del $25 \%$.

Silvia Hooker: Entiendo yo que este tema no se trató, pero se podría poner perfectamente en la norma, sería mejor. El tema fue probablemente porque no hubo consenso y hay países que lo aplican discrecionalmente; yo personalmente pienso que a 
menos discrecionalidad, el procedimiento se torna más transparente y fácil. El acotar algún porcentaje así a rajatabla desde un comienzo, en un mundo tan cambiante donde los precios de los productos finales cada día van variando en cuanto a que las cadenas globales de valor de hoy en día te dicen tú traes de acá o allá, entonces, realmente pienso que no se hizo un estudio económico en ese momento de cuál sería el valor. Me parecería adecuado se incluya un valor. Estudios Económicos de INDECOPI podría hacer un análisis de cuál podría ser la estructura porcentual de los países que se importan.

GiUliana Paredes: Por ejemplo, hay otros términos igualmente amplios, tales como "menor o insignificante".

Silvia HoOKer: El tema de menor o insignificante sí hay bastante literatura de comercio internacional, por ejemplo, se puede tomar como un parámetro el tema de los procesos mínimos para la calificación de origen de un acuerdo comercial. Tienes un listado en los acuerdos donde dicen que determinados procesos no confieren origen, cuando son casos de ensamblaje, reacondicionamiento, empaques, pastillas al por mayor para meterlas en un pomito, entonces, ahí hay todo una discusión, pero hay literatura asociada al tema. Entonces, tú no podrías decir necesariamente en todos los casos porque va a depender del tipo de producto que se trate si hay proceso mínimo o no, pero existen conceptos. Por otro lado, parte de lo que Estudios Económicos le decía a INDECOPI es que hay mucha discrecionalidad de tu parte para que decidas, pero sí es mundo cambiante, tendrías que cada año revisar esa lista de "valor mínimo" o "proceso insignificante". Lo que la tecnología hoy te cuesta un montón, mañana no podría costar nada, entonces, ya se vuelve un valor insignificante lo que hace unos años era un valor importante de acuerdo al valor final del producto.

Giuliana Paredes: De todos modos sería interesante, en materia de elusión, delimitar bien los criterios adscritos a cada fórmula de elusión, eliminando la ambigüedad.

Silvia HoOKer: Claro, definitivamente ese era un proyecto para trabajar, pero sí, todo lo que sea para eliminar lo más que se pueda la discrecionalidad del funcionario, siempre es para mejor predictibilidad del mercado y los agentes. 
Giuliana Paredes: En el tema de partes, piezas y componentes cuando éstos ingresan a nuestro país y se ensamblan dentro de éste. El proyecto establecía que los derechos antidumping originalmente aplicados se extendería al producto final completado o ensamblado en nuestro país. En base a su experiencia ¿cómo podría ser esto posible? Porque las partes, piezas y componentes ingresan, se nacionalizan y después son completadas, entonces, se estaría aplicando derechos antidumping a productos ya nacionalizados. Pienso que sería mejor prorratear el valor que tenga cada parte, pieza y componente respecto al valor total del producto y se establezca un porcentaje dumping a cada elemento por separado para que pueda ser cobrado por ADUANAS.

Silvia Hooker: Sí en realidad sí, lo que pasa es que yo entiendo que sobre el valor final de producto es que se estaría aplicando el derecho antidumping, pero eso se tendría que cobrar en el momento de la importación de las partes, piezas y componentes. Es complicado, pero sí se podría hacer.

GiUliana Paredes: Todos los supuestos tienen un solo procedimiento administrativo. Por ejemplo, si se traen partes, piezas y componentes a precios dumping y se afecta también a la rama de producción nacional de esas partes, piezas y componentes, podría pensarse que ellos tendrían legitimidad para solicitar el inicio de una investigación antielusiva. Por ello, ¿sería más conveniente tener varios procedimientos administrativos?

Silvia Hooker: El tema ahí es que ya no estás en un caso de elusión, sino que estás en un caso completamente nuevo y no siempre vas a tener productores de todas las partes y piezas, lo que podría pasar ahí es que una parte o pieza logre tener un derecho antidumping propio y el resto se quede eludiendo el derecho del bien final cuando todo termine siendo armado aquí.

Giuliana Paredes: Entonces, ¿usted pensaría que es más conveniente tener un solo procedimiento para todos los supuestos?

Silvia Hooker: Sí yo creo que sí, me voy por el procedimiento único en tanto estén bien delimitadas las causales 
Giuliana Paredes: ¿Desde el cargo desde el que usted se desempeña, cuál sería la posición de los exportadores/productores nacionales?

SILVIA Hooker: El productor de industria y manufactura nacional primero que nada consideran que la administración no está haciendo todo lo que debería hacer, tan solo siquiera para seguir los casos de dumping, menos para seguir los casos de elusión. Sí consideran que se hacen esfuerzos muy grandes y no necesariamente todos responden, no tanto por la falta de capacidad, sino por una falta de número de personal y, en el caso de la ADUANA, por la indiferencia que tiene éste último, quien es el que debería ser la primera alerta de los casos de elusión, hay mucha indiferencia porque no hace suyo esos procedimientos de derechos antidumping. Creemos que el Estado debería actuar como uno solo y porque esto o aquello es de otra institución, entonces, no me importa no lo miro. Todos deberían estar muy atentos porque es finalmente la sociedad y la economía la que se afecta y los puestos de trabajo que se pierden producto de esta práctica desleal. Sentimos que la ADUANA que es la que debería estar ahí mirando y no se está poniendo a la altura del reto y eso es algo que se sentimos que está mal. La administración tiene que conversar y ponerse de acuerdo.

GiUliana Paredes: ¿Esta problemática ha sido materia de la agenda del quehacer del SNI?

Silvia HoOker: La batalla que el SIN está dando muy fuertemente es con el hecho de sensibilizar a la autoridad del INDECOPI, ha habido épocas en la que ésta se ha mostrado reacio a aplicar derechos antidumping, pero sin embargo hacía las investigaciones. Hubo una época en la que INDECOPI se volvió más proclive a escuchar los pedidos de la industria nacional y, cumpliendo las normas OMC, a aplicar los derechos antidumping, los cuales, han sido eludidos. Luego otra vez vino una etapa en la que se restringía el uso de estas medidas, incluso al punto que le tomo de un año a un año y medio no para el caso, sino para iniciarlo o para decidir no hacerlo, cuando tiene 30 días decidir si inicia un procedimiento o no. Esto ha sido muy criticado, entonces, la industria nacional se ha abocado a ver que se hagan los casos, al menos que se les escuche, que se le abran los procedimientos y tengan la oportunidad de presentar los sustentos técnicos y económicos. Que le den si les corresponden sino, no, pero en una buena batalla legal, no que se les 
tengan un año esperando si se inicia el procedimiento porque se entendería que no se otorga las garantías mínimas dentro del procedimiento porque no se ha podido ejercer su derecho, eso está preocupando a la industria que la propia elusión porque se siente que no hay tanto derechos aplicados como para que se eluda.

Giuliana Paredes: Esta propuesta se presentó el 2011 y no tuvo mayor asidero, pero en caso se vuelva a plantear el tema, entiendo que ustedes tendrían una posición positiva y activa al respecto.

Silvia HoOKer: Apoyaríamos muchísimo a que se retome una propuesta de éstas, con las mejoras que se identifiquen y que se tengan que hacer, no tenemos una idea fija de cuál, pero creemos que sí, que es momento que se tome en serio el tema, es momento de cambios, así que es ahora cuando tiene que hacerse.

Comentarios.- Con arreglo a la aplicación de derechos antidumping en el Perú, Silvia Hooker reclama que la participación de la Comisión sea más activa, cubriendo más casos por actos desleales en el comercio internacional y gestionando los procedimientos de acuerdo a las disposiciones y plazos establecidos por el Reglamento Antidumping. A pesar de lo señalado líneas arriba, la Gerente de Comercio Exterior de la SNI es consiente que las limitaciones de la Comisión no se debe a la incapacidad de sus funcionario, sino que responde más bien a la falta de funcionarios. Por otro lado, en atención a los problemas que se generan en nuestro mercado por la ejecución de prácticas de elusión que burlan los efectos correctores de los derechos antidumping, Hooker reconoce que es un tema que debe ser discutido porque ello va a permitir garantizar los alcances adscritos a las medidas antidumping que, como ya se mencionó, desde ya se aplican de forma reducida. Finalmente, para la entrevistada, resulta conveniente modificar el Reglamento Antidumping, pues ello va a respaldar el trabajo de los exportadores y productores nacionales. 


\title{
ANEXO N ${ }^{\circ} 5$
}

\author{
Material de Audio
}

\begin{abstract}
ENTREVista a Luis AlBerto LeÓn, SECRETARIO TÉCNICO DE LA COMISIÓN DE DUMPING, SUBSIDIOS Y ELIMINACIÓN DE BARRERAS NO ARANCELARIAS DE INDECOPI, REALIZADA EL 3
\end{abstract}

DE JULIO DE 2014

Giuliana PaRedes: Tenemos referencia de pronunciamiento normativo sobre el tema en el Artículo 58 del Decreto Supremo N ${ }^{\circ}$ 006-2003-PCM ¿Cuál fue la ratio legis que impulsó el pronunciamiento a través de este artículo por parte de Indecopi a través de la Comisión de Dumping y Subsidios?

LUIS LEón: Los derechos antidumping son medidas temporales que afectan económicamente, es una carga sobre las importaciones que entran al país a precios bajos; evidentemente lo que puede ocurrir una vez aplicado tal derecho es que se desarrollen prácticas alusivas para no afrontar la carga efectiva de ésta, este hecho es una cosa natural. Si el importador está sujeto a una medida podría buscar eludirla a partir de conductas evasivas, conductas que intenten justamente salirse del ámbito de la medida dictada, esto es una cosa propia de nuestro país y se ha visto además en otros países. De este modo, frente a ese riesgo de poder eludir las medidas, logrando hacer que la medida sea ineficaz es que se ha decidido emitir normativa al respecto.

Giuliana Paredes: ¿Cree usted que es suficiente tratar dicho tema solo en un artículo que se circunscribe específicamente para el tema de piezas, partes o componentes?

LuIS LEón: El hecho de que sea un artículo, tal vez, no sea tan problemático, lo problemático debiera ser que la regulación aborde o no aborde los elementos más importantes de esta figura en este artículo. El reglamento tiene un conjunto de falencias, tú 
lo has mencionado, que aborda una práctica de elusión a nivel internacional. Revisando la casuística hay formas de elusión más sofisticados que otros, hay supuestos nacionales que estarían siendo cubiertos por el artículo 58, entonces, ahí hay un primer problema; un segundo problema, tiene que ver la tipificación ¿Cómo se tipifica la conducta evasiva?, ¿qué elementos constitutivos debieran tener una conducta para calificarla como evasiva? El artículo guarda silencio y parecería que la medida se trata de un instrumento que puede ampliar el efecto antidumping que pueda tener alguna forma de tipificación un poco más explícita que le dé a los operadores comerciales, más que nada a los importadores, información de si podrían estar incurriendo en un acto de elusión, así no se llega a esta situación, tal vez, de forma involuntaria; de este modo, va a ser más fácil para el importador calcular bien los límites de su actuación. Luego, tampoco hay una regulación explícita sobre el procedimiento, entonces, si no hay una regulación de procedimiento específico deberán aplicarse las reglas generales desarrolladas para el derecho antidumping.

Giuliana Paredes: Como ya lo comenté, este artículo solo incluye un supuesto que hace referencia a las partes y piezas, pero se han desarrollado otros supuestos de hecho que han sido normados, por ejemplo, en Estados Unidos y en la Unión Europea, países que determinan la existencia de prácticas elusivas cuando la producción se traslade al país de exportación, cuando se realiza un modificación sustancia, pero suficiente para que no se apliquen los derechos antidumping, entre otros casos. ¿Qué opinión le merece esta normativa que se ha desarrollado en estos lugares?

LUIS LEÓN: Sí, en materia internacional lo que hay es básicamente dos enfoques; uno, que es muy general, como es el caso de China, y otro que cuenta con mayor precisión. Ahora bien, la experiencia y normativa peruana es similar a la colombiana, pues del mismo modo, se plantean modalidades de elusión sobre las partes, componentes y pieza. A diferencia de ello, en Estados Unidos hay más modalidades previstas; a mí me da la impresión que ello se da por fines de predictibilidad. Creo que lo más adecuado para el tratamiento normativo es que se comprenda primero una cláusula general de lo que es elusión y sus elementos; luego pueden desarrollarse modalidades particulares y más comunes. Visto de ese modo, uno podría decir que nuestra regulación es insuficiente porque no define lo que debería 
entenderse por estas prácticas, tal vez, se requiere de una norma que plantee los dos aspectos antes mencionados así se debería empezar por una definición y ejemplos de modalidades.

GiUliana Paredes: ¿Existe alguna proyección de desarrollar normativamente es tema de elusión y cubrir los vacíos legales que existen?

LUIS LEÓN: El año 2010 se trabajó una propuesta normativa que se publicó en nuestra página web. En este trabajo se diagnosticó fundamentalmente los problemas que estamos tratando y se estableció la forma de reglamentar estas prácticas. El inconveniente es que esta propuesta no ha tenido mayor discusión a nivel del ejecutivo.

GiUliana Paredes: En base a nuestro flujo comercial ¿Nuestro país tiene antecedente por recurrir a mecanismos elusivos?

LUIS LEÓN: Las prácticas elusivas las comete el importador con la complicidad del exportador, digamos que para que alguien pudiera cometer unas prácticas elusivas primero debe existir la aplicación de derechos antidumping a las exportaciones a este país. El Perú solamente tiene medidas aplicadas en Argentina, por tanto, si se quiere determinar si nuestro país está incurriendo en actividades elusivas, tendría que hacerse las investigaciones en Argentina. Más bien, lo que podría ser más útil es si en el Perú se están realizando prácticas elusivas y ahí habría que recurrir a la experiencia prácticas, pero como tenemos una norma tan limitada se ha limitado también la posibilidad de que se denuncien casos y la posibilidad de que se investigue, sin embargo, se han podido advertir en prácticas casos sospechosos. Por ejemplo, se han hecho modificaciones poco sustanciales en un producto, pero basta ello para que el producto cambiara para que no se pueda aplicar el derecho antidumping; este caso lo hemos visto en las planchas de yeso, producto al que se aplicaban medidas antidumping del producto con determinado rango de medidas. Se empiezan a realizar importaciones de las planchas de yeso con más o menos milímetros, entonces, ello hace que ese producto sea excluido de la aplicación de los mecanismos antidumping y por tanto que no se paguen los derechos respectivos. Del mismo modo, tenemos el caso de los vasos que eran fabricados por una empresa, cuyas importaciones estaban sujetas al derecho antidumping. Esa empresa extranjera cambia de razón social y 
empieza a traer nuevas importaciones. Como ya se registra un nombre distinto, los derechos aplicados a la empresa ya no son cobrados. Como tú bien lo has señalado, hay una serie de incentivos que pueden generar la creatividad de los importadores y exportadores de encontrar cada vez diversas modalidades para eludir los derechos antidumping, entonces, en el país sí se podría identificar practicas elusivas no calificadas legalmente como tal porque no tenemos una calificación de ese tipo, pero son casos que no dejan de ser sospechosos.

Giuliana Paredes: ¿La casuística sobre el tema en el Perú puede llevar a concluir que las prácticas elusivas son mecanismos usados por países asiáticos como sucedió con Estados Unidos y países de Europa?

LUIS LEÓN: Para ver quién podría estar eludiendo, tendría que analizarse primero qué derechos estaría siendo eludido. Por ejemplo, el caso del cambio de nombre del proveedor fue un caso de importación de vasos desde Chile, ahí fue claramente la conducta del importador chileno quien cambió de razón social, nunca informó de ello a las autoridades y siguió mandando al Perú dichos productos. El otro caso que te comenté sobre las planchas de yeso fue también de Chile. Hemos visto en la realidad otros casos de cubiertos importados por China, donde se aplicó derechos antidumping, sin embargo, se comenzó a importar el producto con otras medidas de menor espesor; en este caso, el ejecutor fue un país asiático. En todo caso habría que verse en qué gama de productos se puede identificar la realización de prácticas elusivas para ver qué países recurren a éstas. Yo he citado casos de Chile y China.

GiUliana Paredes: Con respecto caso citado por usted sobre las planchas de yeso ¿Cómo terminó dicha investigación?, ¿se ordenó pagar los derechos antidumping?

LUIS LEÓN: No, el artículo 58 reúne un procedimiento de investigación que debiera acabar en eso, es decir, este producto que no es el que está literalmente afecta a las medidas debiera pagar los derechos en razón a las prácticas elusivas realizadas; así es como acaba un procedimiento antielusión o técnicamente como debería terminar. En el Perú nunca ha habido un procedimiento antielusión bajo esa actividad legal lo que ha habido es básicamente la iniciación de un procedimiento bajo las bases del antidumping. En el caso 
de las planchas de yeso, Indecopi tomó conocimiento de manera formal porque el productor nacional mandó un comunicado sobre ello, Indecopi, en primera instancia, mandó a dicho proveedor a que pague y se haga el cobro respectivo. Sin embargo, el caso pasó a la Sala quien señaló que había habido una violación impuesta por el Indecopi. El Tribunal dijo que como es un producto industrial es posible aplicarse tolerancias técnicas de +1 o -1 . Por ejemplo, si el producto investigado haya tenido 5 pulgadas y este está ingresando con 6 pulgadas. El caso se fue al contencioso y en la instancia de Corte Suprema se logró que se anulara la decisión de Indecopi. Lo que dijo el juez, con un razonamiento sencillo, fue: tú le aplicaste derecho antidumping a la plancha de 5 pulgas y nuca lo hiciste con las planchas de yeso de 6 pulgadas, por tanto, tú no puedes venir a aplicar tus técnicas antidumping a un producto que no había incluido desde un inicio en tu supuesto de hecho. Finalmente, el juez ordenó la anulación de la orden de cobro, por ello, no ha habido, salvo estas planchas de yeso, casos en que Indecopi haya ordenado a un importador el pago de derechos antidumping por prácticas elusivas. Lo que ha habido son observaciones de que podrían existir prácticas elusivas, hecho que justificó el proyecto normativo que se hizo hace unos años.

Giuliana Paredes: Al igual que Perú muchos otros países se han pronunciado legislativamente sobre el tema ¿Cree usted que esta proliferación normativa unilateral puede generar desventajas en el ámbito comercial? Si es así ¿cuáles serían las dificultades que percibe?

LUIS LEÓN: El tema es práctico, en las reglas de comercio unilateral lo que se ha planteado es que a partir de las normas que ha emito la OMC todos los países vean que se han plasmado sus intereses y al final consensuar todas las reglas que se van a aplicar a todos como, por ejemplo, las reglas del antidumping. En las reuniones de Uruguay se planteó también el tema de elusión y no hubo un acuerdo, entonces se derivó esto a un comité especial que estuvo trabajando muchos años, pero que nunca logró frutos justamente porque no había consenso, entonces, se preguntaron: ¿Qué hacemos para esperar a consensuar? o en el uso de nuestra soberanía podemos aplicar reglas q sean consistentes con las normas de OMC, pero que permitan a los países miembros regular este tipo de derechos; esto es lo que efectivamente a estado ocurriendo y que tú bien lo has podido 
observas, pues año tras año los países siguen ejerciendo las prácticas elusivas. Entonces, la pregunta sigue teniendo un carácter práctico. Lamentablemente, el comité designado no ha progresado en sus trabajos, pues no ha habido ningún avance, por lo menos, en estos últimos 4 o 5 años. Entonces, espero que algún día ocurra el milagro o los países de manera responsable tomen la decisión de poder reglamentar el tema.

Giuliana Paredes: Con respecto a la solución planteada ¿De qué forma debería consistir el pronunciamiento de la OMC?

LUIS LEÓN: Las prácticas de muchos países ya van orientando hacia donde debieran apuntar una normativa multilateral; así una legislación multilateral debe hacer una identificación de los elementos que constituyen una conducta elusiva.

Comentarios.- Luis Alberto León manifiesta que se han configurado diversos casos que no pueden ser calificados de elusivas, pues no existe una base legal que permita hacerlo, sin embargo, tras el análisis de estos hechos se ha notado que existirían características similares a las de las conductas de elusión de derechos antidumping. Con arreglo a ello resulta conveniente modificar el artículo 58 del Reglamento Antidumping, pues éste es muy limitado y no aborda, como se debe, este problema. Por ello, la Comisión ha desarrollado una propuesta para modificar la normativa antidumping nacional, disponiendo la inclusión de disposiciones antielusivas. 


\title{
ANEXO N ${ }^{\circ} 6$
}

\author{
Material De Audio
}

ENTREVista A Luis Alberto LeÓn, SECRETARIo TÉCNICO DE LA COMISIÓN DE DUMPING, SUBSIDIOS Y ELIMINACIÓN DE BARRERAS NO ARANCELARIAS DE INDECOPI, REALIZADA EL 11 DE NOVIEMBRE DE 2016

Giuliana Paredes: ¿Por qué el Proyecto de Modificación del Reglamento antidumping contiene diversos términos vagos y ambiguos que podrían desvirtuar la propuesta?

LUIS LEón: Cuando uno revisa mucho la normativa de la OMC suelen haber términos no necesariamente aterrizados a niveles cuantitativos, normalmente se debe porque cada caso puede generar circunstancias distintas y cada caso, depende del tipo de producto, los niveles en que las partes, piezas y componentes aportan al producto final. Sin embargo, entendemos también la preocupación que pueda generarse a partir de que no se establezca un grado numérico, esto también puede tener una incidencia sobre la predictibilidad, es decir, qué debieran esperar los agentes del mercado cuando se hacen este tipo de operaciones, esperar si van a estar sujetos a una posible investigación por elusión o no, ciertamente es una preocupación válida. Me parece que en otras legislaciones se ha hecho el intento de cuantificar este tipo de condiciones, me parece que la legislación de Colombia tiene un umbral que bien podría incorporarse para dar una mayor certidumbre a este tipo de regulación.

Giuliana Paredes: Con arreglo al término "menor o insignificante" la legislación norteamericana establece criterios para esclarecer este término.

LUIS LEÓN: Son dos alternativas distintas: criterios cualitativos y un umbral numérico. La primera alternativa da cierta flexibilidad para poder fijar, caso por caso, cuál es la solución correcta para un caso en particular, eso puede hacer que la decisión sea más aproximada a 
lo apropiada para el caso en particular, sin embargo, sí tiene costos mayores porque hay que indagar en una serie de elemento que no necesariamente puedan estar disponible, por ejemplo, el valor de la inversión en el tercer mercado puede ser una información no tan disponible ni para la autoridad, ni para las partes. Por otro lado, para el umbral numérico, si bien es cierto, puede ser en algunos casos hasta arbitrario por que puede ser un 2, 3 o $4 \%$, pero es cierto que también pueda tener beneficios, desde la propia normativa se sabe que si se llega al umbral, se sabe que podrían estar sujetos a fiscalizaciones de elusión y, por tanto, los costos de administración y de tramitación de este tipo de herramientas también serán analizadas sustancialmente. Son dos criterios bastante válidos que deben ser ponderados si quieren encontrar la mejor solución para una regulación que debiera estar en manos de una autoridad como la peruana. Criterios como las que aplica Estados Unidos suelen ser normalmente criterios que no importan tantos costos a la autoridad porque debido al tamaño que tiene el mercado estadounidense, cuando se establecen este tipo de procedimientos e investigaciones, normalmente hay mucha participación de los involucrados porque normalmente los Estados Unidos es uno de los principales destinos de los exportadores y en tanto hay incentivos para que los exportadores participen y den información. En mercados más pequeños lo que podría ocurrir es que no haya ese nivel de participación, no se cuente con la información necesaria para hacer este tipo de análisis, cuando ese tipo de análisis se basen en elementos que deben ser razonables y adecuados, podría uno encontrarse con limitaciones prácticas.

Giuliana Paredes: Sobre la condición del umbral numérico se han aplicado las reglas del $60 \%$ y $25 \%$, el cual ha sido incluido en la legislación europea y en los drafts emitidos por la OMC. ¿Por qué no se incluyeron estos criterios cuantitativos dentro de la propuesta?

LUIS LEÓN: Porque en un primer momento se consideró que era más adecuado ir por un camino de criterio más cualitativos, del caso por caso; dar, a partir de la jurisprudencia, el contenido de lo que es significativo o no, pero de hecho ante las dudas e inquietudes, también era válido evaluar ese tipo de alternativas relacionadas a umbrales numéricos. De hecho pareciera ser lo mejor para una autoridad como la peruana, donde los costos de tramitación de estos elementos pueden ser muy elevados. 
Giuliana Paredes: En el caso de Tejidos Tipo Popelina parecería haberse configurado un supuesto de elusión, conocido en la legislación internacional como downstream circumvention, el cual no ha sido materia de discusión en la exposición de motivos, ¿debería ser conveniente incluir además esta fórmula elusiva dentro de la propuesta normativa de modificación del artículo 58 del Reglamento Antidumping?

LUIS León: Esa es la modalidad inversa, acá en vez de colocar al producto en partes y piezas para armarlo, en este caso lo que se veía es que se traía el producto ya terminado en base al insumo que sí tenía medidas antidumping en el Perú. Ahí se identificó que ese supuesto no estaba establecido en la normativa. En el proyecto original se estableció un supuesto de elusión para importación de insumos bajo una lógica parecida, esa propuesta generó una serie de preocupaciones para determinadas empresas peruanas, la preocupación que se planteaba era ¿cómo se podía partir de un insumo, el cual puede ser importado para cualquier tipo de finalidad y respecto a la utilización de ese insumo para la utilización de un sector en particular, podía llegarse a gravar el insumo con derechos antidumping que correspondían a otro tipo de producto. Digo que es similar porque uno termina hablando de un producto que requiere transformación para convertirse en otro producto y ahí hubo una serie de preocupación. Ahora, respecto al otro supuesto que se menciona, la verdad es que no encontramos jurisprudencia a nivel internacional, pero también existe una preocupación ¿cómo es que podría llegar a entenderse que la importación de un producto final pueda estar realizando bajo la pretensión de eludir el derecho al insumo, en la medida de que pueda haber algún grado de valor agregado adicional para convertir a un producto final?. El paso de un insumo a un producto final requiere también de determinadas pautas y criterios para no generar una regulación que sea arbitraria porque bajo esa lógica todos los productos están hecho mediante insumos, habría que ser súper cuidadosos para ver cuándo se considera que el paso del insumo al producto final pueda estar generando una práctica elusiva.

Giuliana Paredes: ¿Cómo se proyecta la aplicación de medidas antielusivas en este supuesto de elusión?, ¿Qué tan viable es que se extiendan las medidas antidumping una vez que las partes son nacionalizadas, ensambladas y completadas dentro del territorio nacional?, ¿Se podría establecer el valor de cada parte, pieza o componente respecto al 
valor total de la mercancía ensamblada o completada y establecer y prorratear el derecho antidumping por cada parte, pieza y componente en el momento de que éstas ingresan a ADUANAS?

LUIS LEÓN: La ampliación del derecho jugaría en torno a las partes, piezas o componentes que vienen del país afecto a medidas o del producto final ensamblado a partir de esas partes, piezas o componentes hecho en un tercer país no afecta a esas medidas. Para el supuesto donde el ensamblaje se realiza en nuestro país, el prorrateo o asignación se hace en función al valor del producto final y de cómo aporta cada parte, pieza o componente a ese valor. De hecho si se diera el caso y así me imagino que ocurre en otros países, el derecho se aplica como lo cobra ADUANAS y se aplica sobre las partes, piezas y componentes que están siendo importados para efectos de luego ensamblar el producto final, pero claro la investigación debe ser precisa en señalar cuáles son esas partes, piezas y componentes. Además, me parece que esto se presta mucho a maniobras

Giuliana Paredes: Además, otra de las aristas que he podido identificar en razón de este supuesto elusivo es que los productores nacionales de esas partes, piezas y componentes podrían estar legitimados, además, a solicitar el inicio de un procedimiento por elusión.

LUIS LEÓN: Sí de hecho que podrían hacerlo, si se siente afectadas por el ingreso de ese producto en particular, pero ahí hay que tomar en cuenta si es que estamos hablando de un único mercado o dos mercados distintos. Es decir, si en el país hay un mercado para elaborar partes, piezas y componentes son utilizadas por una industria distinta que es una industria de ensamblaje del tipo de producto porque si no es así y vemos que la industria funciona de manera integrada, entonces, ahí no hay dos mercados, por lo que sería más claro que la importación de estas partes, piezas y componentes tienen un fin elusivo.

GiUliana Paredes: ¿Qué tan viable es que se establezcan procedimientos independientes para cada supuesto de elusión?

LUIS LEÓN: La parte del procedimiento es principalmente pasos y actuaciones procesales para llegar a un resultado, pareciera visto así que es independiente de criterios o pautas técnicas que deben utilizarse para identificar una determinada conducta elusiva, respecto de otra porque la investigación, los actos procesales intermedios antes de llegar a la decisión 
final, las publicaciones de actos, parecerían que podrían ser transversales, de repente más que procedimientos, podrían ser criterios especiales y desarrollarse para cada figura, en la medida de que cada figura tenga sus particularidades. Esta propuesta sin duda también podría darse.

Giuliana Paredes: El proyecto de modificación contiene diversas fórmulas de elusión y una cláusula general, el cual establece criterios para supuestos no establecidos expresamente en las disposiciones. Con la finalidad de que las decisiones sean más predecibles y generen más certeza en los agentes de mercado, ¿sería preferible incluir además una definición de lo que la autoridad considera por práctica de elusión de derechos antidumping?

LUIS LEÓN: De alguna manera el proyecto original trató de brindar elementos de configuración general de una práctica de elusión: cambios de los patrones del comercio, que no haya una justificación económica para ese cambio, que los patrones ocurran después de iniciada la investigación y que no haya otra justificación más que eludir. De alguna manera se establecen los criterios para una práctica elusiva. Formalmente el Acuerdo de la OMC y la normativa internacional no suelen hacer definiciones, en muy pocas ocasiones se hace, más bien es más importante establecer las características generales que debe tener una determinada conducta para que, en base a esas características, pueda evaluarse en cada caso aquellas actuaciones que puedan dar lugar a una elusión.

Giuliana Paredes: Ya que existen dos supuestos de elusión que se relacionan con las normas de origen no preferencial, ¿sería conveniente dejar en claro el rol de otras instituciones como el MINCETUR para la emisión de Resoluciones Ministeriales que establecen los criterios para el origen no preferencial y la SUNAT para hacer cumplir dichas Resoluciones?

LUIS LEÓN: Sería conveniente las normas de cómo determinar el origen, de hecho es mejor que para cada derecho se tenga un tipo de precisión de origen de modo tal que si algún importador le solicita a la ADUANA que no le cobre derecho porque, aun siendo procedente su producto del país afecto a medida, no debe ser considerado como originario 
de ese país, la ADUANA puede contar con las herramientas para hacer esa evaluación. El Decreto de MINCETUR asigna competencia expresamente a ADUANA sobre la materia.

GiUliana Paredes: La posición que se manifiesta en contra de la normativa antielusión señala que estas disposiciones estarían abiertamente en contra del GATT y del Acuerdo Antidumping ¿Qué opinión tiene usted respecto a esa postura?

LUIS LEÓn: Los países que somos miembros de la OMC hemos asumido compromisos para, cada vez que aplicamos medidas antidumping, hacerlo bajo las reglas de la OMC, también los países que nos hemos adherido a la OMC hemos asumido el compromiso de poder solucionar nuestras diferencias en los foros propios de la OMC, a través del Órgano de Solución de Diferencias, bajo un contexto en el cual todos los países nos hemos comprometido a hacer que nuestras legislaciones nacionales sean consistentes con las normas de la OMC. De este modo, la violación de una norma de la OMC, la transgresión de compromisos internacionales asumidos por el Perú u otro país en el marco del acuerdo antidumping $\mathrm{u}$ otro acuerdo de la OMC, pueda ser sancionada a partir de los pronunciamientos de los órganos de solución de diferencias de la OMC y el órgano de apelación; si un país pensara que su interlocutor comercial aplica legislaciones que no están siendo consistentes con lo que establecen los acuerdos de la OMC, puede someter esta controversia al órgano de solución de diferencias. Entonces, para cualquier actor de mercado, para cualquier interesado, para cualquier agente económico puede ser correcto o pertinente afirmar que una u otra normativa viola la normativa de la OMC, pero esa determinación la efectúa los órganos especiales y el órgano de apelación de la OMC. Dicho esto, en el mundo existen una diversidad de países, dentro de los cuales se encuentran los países más importantes por flujo comercial, digamos Estados Unidos, la Unión Europea, China, India, Brasil, México que tienen normativa antielusión y no solo eso sino que la ponen en práctica. Cuando uno revisa, por ejemplo, la información de la jurisprudencia de la Unión Europea va a encontrar una diversidad de casos, en donde las autoridades están aplicando las medidas antielusión y frente a esas decisiones no ha habido, primero, reclamos de países a la OMC cuestionando que la aplicación de esas medidas antielusión sean contrarias a la normativa de la OMC y, segundo, producto de lo anterior, es evidente que no hay ningún pronunciamiento de grupos especiales o de apelación en el sentido de 
señalar que ese tipo de normativa violas los compromisos asumidos ante la OMC, entonces, desde un punto de vista jurídico y objetivo, podemos decir que esos pronunciamientos carecen de fundamento. Si a alguno de los agentes comerciales les pueda preocupar de forma legítima que al hacer operaciones de comercio puedan estar sujetas a investigaciones es completamente entendible, pero lo que también hay que entender es que en este contexto, con una globalización de los mercados, todos quienes participen en el comercio sean productores, exportadores o importadores tienen que estar sujetos a la diversidad de unas normas legales que han asumido los países; una de esas reglas legales es no hacer dumping en un país donde se cause daño a una rama de producción nacional y otra regla que han asumido con miras a la soberanía que tiene cada país de establecer regulaciones nacionales es sujetarse a esas regulaciones y si estas implican una violación a una norma o tratado internacional, lo más adecuado es acudir al foro de la OMC, pero nada de esto ha ocurrido. Por eso entendemos que se pueden tratar de preocupaciones legítimas pero no tienen mayor asidero legal.

GiUliana Paredes: Hubo un conflicto entre Japón y la Unión Europea que fue materia de pronunciamiento por el Panel del GATT y no se declaró expresamente que las medidas antielusivas estaban prohibidas y tampoco se determinó de que éstas fueran contrarias al GATT.

LUIS LEÓn: Como tu bien lo has señalado, el Acuerdo Antidumping no tiene regulación sobre la elusión, si una revisa la jurisprudencia de la OMC lo primero que va a encontrar es que no existe una obligación acordada y consensuada por los países miembros, no se puede hablar de una violación a una disposición porque esa disposición no existe. Lo que valdría preguntar es si a nivel de la OMC puede ser legítimo algún tipo de preocupación de la medida antielusión, lo que podría dar lugar a que los países ya unilateralmente, en base a su soberanía nacional, puedan establecer regulaciones para hacer cumplir una medida que ha sido adoptada siguiendo las reglas de la OMC; de nada valdría hacer investigaciones que duran un año o año y medio siguiendo todos los requisitos de la legislación internacional, cuando esas medidas no van a tener herramientas detrás que la respalden y de hecho otro punto interesante es que si bien la OMC no tiene normas de medidas de elusión, lo que sí hay es una recomendación del Consejo de Ministros, que es el órgano válido de la OMC 
que establece los criterios o recomendaciones de la OMC con carácter vinculante, es decir, del órgano que realiza interpretación auténtica de los acuerdos, el cual establece una recomendación para que el tema sea estudiado a través de un comité especial porque efectivamente había la preocupación de que estas medidas puedan poner en riesgo la efectividad del sistema. Entonces, a partir de una evaluación bastante objetiva porque podemos que puede haber disgusto, preocupación, pero a través de una investigación objetiva, lo que hay abona más bien a que las medidas antielusión puedan ser utilizadas, de hecho en el mundo están siendo utilizadas, entonces, los países tienen que ponderar cómo utilizan de mejor manera los mecanismo para defender sus intereses porque renunciar a una herramienta bien puede ser lícito, pero en un escenario mundial de tanta competencia, donde los países están luchando día a día por obtener espacios donde puedan colocar sus exportaciones, un país puede competir con desventaja si es que no aplica o renuncia a aplicar herramientas que otros están aplicando

Giuliana Paredes: ros Claro, tenemos por un lado que el Acuerdo Antidumping y el GATT no prohíben la aplicación de medidas antielusivas; por otro lado, tenemos que el único pronunciamiento oficial del GATT fue inhibirse de establecer que estas medidas son ilegales de acuerdo a las normas internacionales; tenemos además que se estableció a nivel internacional que la elusión es una problemática y se delegó a una Comisión el estudio del tema, emitiéndose textos que podrían esbozar la forma de regularlo; finalmente, tenemos que desde la Ronda de Uruguay no se ha podido arribar a una solución que, de forma consensuada, uniformice la aplicación de medidas de antielusión. Por ello, y en base a todos estos hechos, resultaría legítimo que se emita disposición en contra de la elusión.

LUIS LEÓN: Son discusiones a dos niveles distintos. Un nivel plantea la pregunta de si se puede establecer normativa antielusión, lo que puede ser cuestionable es que quienes digan que no sustenten su posición en que es disconforme a la normativa de la OMC. En tanto las normas multilaterales, que puedan ser aplicadas a todos, no existan, no implica que los países no puedan adoptar normas propias, de hecho los países las adoptan. Siendo así, no se entendería cómo China, Estados Unidos, la Unión Europea, Turquía, México están regulando al respecto, la única forma de entenderlo es que todos los países estarían equivocados y siendo todos ellos importantes actores comerciales, no creo que sea así. . Lo 
otro es lo que ya tú has mencionado, una vez de que se ha determinado de que es válido establecer normativa antielusión, la otra pregunta es cómo lo establecemos y coincido contigo al decir que la mejor forma de establecerla es de forma sensata y cuidadosa.

GiUliana Paredes: Teniendo en cuenta que determinar el producto similar es un paso preponderante para el inicio de un procedimiento de investigación y considerando que un posible procedimiento antielusión contiene aristas disímiles a las del dumping, ¿sería conveniente incluir otros criterios además de la similitud física y de uso?

LUIS LEÓN: Sí, la idea es que cuando se habla de producto similar, la medida sea ampliada a un producto que sea sustancialmente el mismo al producto que está afecto a medida. De ahí que la definición del producto similar puede ayudar, entonces, el hecho de sumar otras consideraciones para que se pueda reforzar y asegurar de que eso se cumpla, sí sin ninguna duda es óptimo.

Comentarios.- Por un lado, Luis León señala que resulta legítimo emitir normativa unilateral que aborde la problemática que generan las medidas de elusión, pues son varios países los que ya están aplicando disposiciones antielusivas. Por ejemplo, si revisamos jurisprudencia extranjera, notaremos que las autoridades competentes ya están aplicando medidas antielusión que consiste principalmente en la extensión de los derechos antidumping aplicados originalmente.

Por otro lado, si bien el Proyecto de modificación del Reglamento Antidumping ha sido emitido con un ánimo de cubrir el vacío legal referente a las prácticas de elusión de los derechos antidumping, León reconoce que existen términos vagos que generan incertidumbre y legítima preocupación en los agentes de mercado, por lo que, admite que sería preferible delimitar los alcances de lo que se entiende por producto similar, proceso menor o insignificante, valor significativo, entre otros. El Secretario de la Comisión concuerda con la conveniencia de incluir criterios cuantitativos y cualitativos que delimiten de mejor manera la propuesta normativa. 